\title{
AVALIAÇÃO DE AGROECOSSISTEMAS DO CINTURÃO VERDE DA GRANDE SÃO PAULO QUE RECEBERAM APLICAÇÃO DE COMPOSTO DE RESÍDUOS SÓLIDOS URBANOS POR LONGOS PERÍODOS
}

\section{Antônio Carlos Caetano Marchiori}

Engenheiro Agrônomo

Orientador: Prof. Dr. José Carlos Chitolina

Dissertação apresentada à Escola Superior de Agricultura "Luiz de Queiroz", Universidade de São Paulo, para obtenção do título de Mestre em Agronomia, Área de Concentração: Solos e Nutrição de Plantas.

\author{
PIRACICABA \\ Estado de São Paulo - Brasil \\ Maio - 2000
}


Dados Intemacionals de Catalogaçăo na Publicaçăo (CIP) DIVISĀO DE BIBLIOTECA E DOCUMENTAÇAO - Campus "Luiz de Queiroz"/USP

\author{
Marchiori, António Carlos Caetano \\ Avaliaçāo de agroecossistemas do cinturäo verde da grande Săo Paulo que \\ receberam aplicação de composto de residuos sólidos urbanos por longos períodos I \\ António Carios Caetano Marchiori. - - Piracicaba, 2000. \\ $185 \mathrm{p}$. \\ Dissertação (mestrado) - - Escola Superior de Agricultura Luiz de Queiroz, 2000. \\ Bibliografia. \\ 1. Adubaçăo orgànica 2. Ecossistema agricola 3. Metal pesado 4. Micronutriente \\ 5. Oligoelemento 6. Poluição do solo 7. Relax̧ão solo-planta 8. Resíduo urbano 9. \\ Toxicidade 1. Titulo
}

CDD 631.86

"Permitida a cópia total on parcial deste documento, desde que citada a fonte - 0 autor" 
dedico este trabalho aos meus pais

\section{Maria José e Rogério}

por amor e pelo que já semearam em suas vidas 


\section{AGRADECIMENTOS}

Ao professor Chitolina, pela orientação e exemplo de postura científica.

Aos agricultores das áreas estudas: Hasegawa, Sonoda, Noda e Donizete,.

Aos funcionários Carlos, Gertrudes, Rita e Lenita pelo suporte laboratorial.

Àos funcionários da biblioteca da ESALQ, em especial a Katia, Eliana e Ailton e, ao pesquisador Ronaldo Berton, pela ajuda nas referências bibliográficas.

Aos professores Melfi, Cerri, Takashi, Kiehl, Celso e Jairo, a pesquisadora Mônica Abreu, e aos amigos Rogério, Beth, Luciano, Vladimir, Angela, Helder, Cristiane, Eduardo e Lico pelo apoio.

Às secretárias Angélica, Geovana, Flávia e Márcia pelo suporte administrativo.

À professora Célia Montes-Lavar e ao pesquisador Otávio Camargo pelas críticas e sugestões.

Ao CNPq, pela concessão da bolsa de estudos e a ENTERPA, pela acesso a listagem de consumidores de composto.

À CATI e à ESALQ, pelo apoio no acesso às propriedades estudadas e pela oportunidade de freqüentar o curso.

Ao professor Paschoal pela oportunidade de monitorar a disciplina Agroecologia e Agricultura Orgânica e a CAPES pela concessão de bolsa para a atividade. 
Aos professores da UNESP Jaboticabal, pela minha formação agronômica, em especial a Esmeralda, ao Pitelli, Donadio e Paulo Donato ("in memorian").

À professora Maria Alice Garcia, pelos ensinamentos de Agroecologia recebidos.

Ao Jorge Mautner, pela extração da pérola bíblica:

"Vaidades. Vaidades das vaidades. Tudo é vaidade. "

Eclesiastes 1:2

E ... principalmente ...

Gostaria de agradecer a Janaina

pelo amor e companheirismo durante a execução deste trabalho 


\section{SUMÁRIO}

Página

RESUMO

viii

SUMMARY

$x$

1 INTRODUÇÃO

01

2 REVISÃO DE LITERATURA

2.1 Destinação do composto de resíduos sólidos urbanos (CRSU) .... 5

2.2 Microelementos na agricultura ................................................ 7

2.3 Os agroecossistemas e a aplicação de CRSU …........................... 9

2.4 Efeitos da utilização do CRSU em agroecossistemas

2.4.1 Efeitos da utilização do CRSU no solo

2.4.1.1 Efeitos em atributos micromorfológicos

10

2.4.1.2 Efeitos em atributos microbiológicos .............................. 11

2.4.1.3 Efeitos em atributos físicos ........................................... 15

2.4.1.4 Efeitos em atributos químicos

2.4.1.4.1 Aspectos gerais relativos à fertilidade do solo

2.4.1.4.2 Efeitos em teores totais e biodisponiveis

de microelementos

- Fontes antropogênicas de microelementos

potencialmente tóxicos

- O CRSU como fonte de microelementos

potencialmente tóxicos 
- O acúmulo de microelementos potencialmente tóxicos nos solos agrícolas ........................... 26

- Biodisponibilidade de microelementos potencialmente tóxicos ................................. 28

2.4.1.4.3 Extração seqüencial de microelementos ...................... 34

2.4.2 Microelementos potencialmente tóxicos nas plantas

2.4.2.1 Absorção e transporte de microelementos em plantas ......

2.4.2.2 Riscos tóxicológicos para a alimentação humana

Bioacumulação e biomagnificação ............................. 40

Toxicologia dos microelementos para seres humanos $\quad 41$

3. MATERIAL E MÉTODOS

\subsection{Solos}

3.1.1 Escolha e localização dos solos .................................. 44

3.1.2 Caracterização climática .......................................... 47

3.1.3 Caracterização dos solos estudados .......................... 48

3.1.4 Amostragem dos solos ............................................ 51

3.1.5 Preparo das amostras para análise ............................ 54

3.1.6 Atributos micromorfológicos ..................................... 54

3.1.7 Atributos microbiológicos ........................................... 54

3.1.8 Atributos físicos e físico-químicos .............................. 55

3.1.9 Teores totais e teores considerados biodisponiveis dos microelementos no solo ..................................... 56

3.1.10 Extração seqüencial dos microelementos .................. 57

3.2 Plantas

3.2.1 Amostragem das plantas ........................................ 57

3.2.2 Preparo das plantas para análise .............................. 58

3.2.3 Teores dos microelementos nas plantas .................... 59

3.3 Análises estatísticas ..................................................... 59

4 RESULTADOS E DISCUSSÃO

\subsection{Solos}

4.1.1 Atributos micromorfológicos 


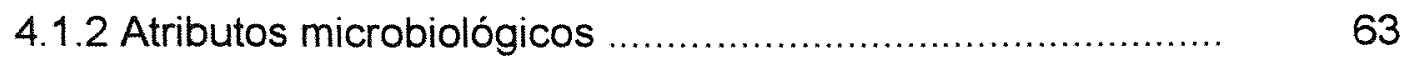

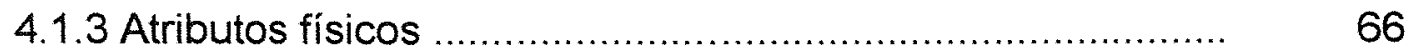

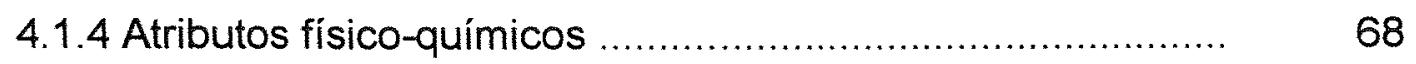

4.1.5 Atributos químicos ................................................

4.1.5.1 Avaliação da fertilidade do solo ................................. 75

4.1.5.2 Teores de microelementos (totais e biodisponiveis)

4.1.5.2.1 Boro (teores biodisponiveis) ................................ 77

4.1.5.2.2 Cádmio (teores totais) .......................................... 78

4.1.5.2.3 Crômio (teores totais) ........................................... 82

4.1.5.2.4 Cobre (teores totais e biodisponíveis) .................... 83

4.1.5.2.5 Ferro (teores totais e biodisponíveis) .................... 86

4.1.5.2.6 Manganês (teores totais e biodisponiveis) .............. 87

4.1.5.2.7 Molibdênio (teores totais) ................................... 89

4.1.5.2.8 Níquel (teores totais) ........................................... 91

4.1.5.2.9 Chumbo (teores totais) ..................................... 92

4.1.5.2.10 Zinco (teores totais e biodisponíveis) ................... 94

4.1.5.3 Extração seqüencial .................................................. 96

4.2 Plantas

4.2.1 Teores de microelementos nas folhas de alface ............... 105

4.2.2 Distribuição dos microelementos nas diversas partes das plantas de alface e beterraba ................................ 113

4.2.3 Toxicidade para a espécie humana .............................. 117

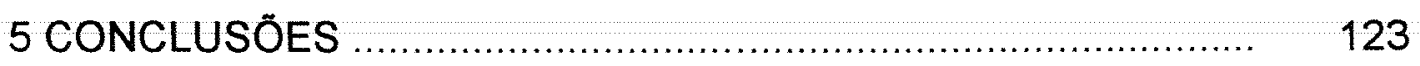

REFERÊNCIAS BIBLIOGRÁFICAS ....................................... 126

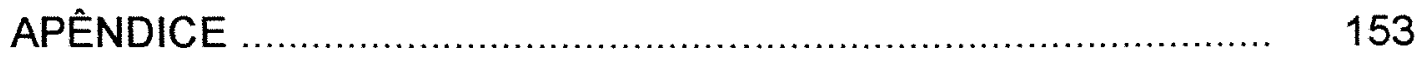




\title{
AVALIAÇÃO DE AGROECOSSISTEMAS DO CINTURÃO VERDE DA GRANDE SÃO PAULO QUE RECEBERAM APLICAÇÃO DE COMPOSTO DE RESÍDUOS SÓLIDOS URBANOS POR LONGOS PERIODOS
}

\author{
Autor: ANTÔNIO CARLOS CAETANO MARCHIORI \\ Orientador: Dr. JOSÉ CARLOS CHITOLINA
}

\section{RESUMO}

O presente estudo foi conduzido com o objetivo de verificar os efeitos da aplicação do composto de resíduos sólidos urbanos (CRSU), por longos períodos, em solos (glei húmico e podzólico vermelho-amarelo) e plantas (alface -Lactuca sativa L. e beterraba - Beta vulgaris L.) da região do cinturão verde da Grande São Paulo.

As aplicações de CRSU foram realizadas de 1982 a 1989 e de 1994 a 1997 no solo glei húmico e em 1989 e de 1994 a 1997 no solo podzólico vermelho-amarelo, na taxa de $200 \mathrm{~m}^{3} \mathrm{ha}^{-1} \mathrm{ano}^{-1}$ ( $80 \mathrm{Mg} \mathrm{ha}^{-1}$ ano-1 - base seca).

Numa primeira etapa, foram coletadas amostras de solos e plantas em áreas sob o cultivo de alface e beterraba e amostras de solo em áreas adjacentes com predominância de gramíneas, não cultivadas anteriormente e que nunca receberam aplicação de CRSU.

Numa segunda etapa, foram coletadas amostras em áreas sob cultivo de alface no glei húmico, na mesma propriedade da primeira fase, e em duas propriedades adjacentes a esta que nunca receberam CRSU.

Foram feitas, nos solos, avaliações micromorfológicas (análise ao microscópio eletrônico associada à análise química semiquantitativa), microbiológicas (biomassa e contagem do número mais provável de fungos e bactérias), físicas (densidade e condutividade elétrica) e químicas (fertilidade e os microelementos $\mathrm{B}, \mathrm{Cd}, \mathrm{Cr}, \mathrm{Cu}, \mathrm{Fe}, \mathrm{Mn}, \mathrm{Mo}, \mathrm{Ni}, \mathrm{Pb}$ e $\mathrm{Zn}$ - teores totais, extraiveis em DTPA e extração seqüencial) e também para todos estes microelementos nas plantas. 
Os resultados obtidos para os parâmetros micromorfológicos, microbiológicos e físicos revelaram que, com exceção da condutividade elétrica, não houve diferenças marcantes entre as áreas tratadas ou não com CRSU.

Verificou-se que a aplicação de CRSU aos solos aumentou a fertilidade, havendo uma elevação do $\mathrm{pH}$, com conseqüente diminuição nos valores de $\mathrm{H}+\mathrm{Al}$ e aumento da CTC e porcentagem de saturação de bases.

Quanto aos teores totais e extraiveis em DTPA dos microelementos nos solos, o $\mathrm{Cu}$ e o $\mathrm{Zn}$ foram os que apresentaram os maiores incrementos nas áreas tratadas com CRSU quando comparadas às áreas não cultivadas tomadas como referência nos dois solos, ou às áreas cultivadas adjacentes que nunca receberam aplicação de CRSU no glei húmico. Os teores totais destes elementos situaram-se dentro da faixa de valores encontrados em condições naturais para solos do Estado de São Paulo.

A extração seqüencial foi feita utilizando-se as amostras de solos coletadas na primeira etapa. Verificou-se que para a maioria das amostras os elementos estudados ( $\mathrm{Cd}, \mathrm{Cr}, \mathrm{Cu}, \mathrm{Fe}, \mathrm{Mn}, \mathrm{Ni}, \mathrm{Pb}$ e $\mathrm{Zn}$ ) se encontravam principalmente na fração residual, com exceção do $\mathrm{Mn}$. Nos dois solos tratados, o Cu apresentou-se predominantemente associado à matéria orgânica e o Zn mais associado a óxidos. No podzólico o Cu, além da fração orgânica, esteve também associado a óxidos e presente na fração residual.

Os teores nos tecidos vegetais estão abaixo dos considerados como fitotóxicos, com exceção do $\mathrm{Cr}$ e $\mathrm{Cu}$ em algumas amostras, não sendo observado nenhum sintoma externo de fitotoxicidade. A distribuição dos microelementos nas diferentes partes das plantas (raiz, caule e folhas), mostrou um predomínio de maiores teores nas raizes, mas foi observada grande variabilidade. As diferenças fisiológicas entre espécies não permite a extrapolação de resultados, principalmente entre plantas cuja parte consumida é a parte aérea para plantas de raízes comestiveis.

Apesar de não exibirem sintomas de fitotoxicidade, algumas amostras de plantas cultivadas em solos tratados com CRSU apresentaram teores de $\mathrm{Pb}$ acima do permitido para a alimentação humana. 


\title{
EVALUATION OF AGROECOSYSTEMS OF THE GREEN BELT OF GREAT SAO PAULO UNDER APPLICATION OF MUNICIPAL REFUSE WASTE COMPOST FOR LONG TERM PERIODS
}

\author{
Author: ANTONIO CARLOS CAETANO MARCHIORI \\ Adviser: Dr. JOSE CARLOS CHITOLINA
}

\section{SUMMARY}

This study was carried out to verify the effects of the application of compot waste for long term periods in soils (humic gley - haplaquents and redyellow podzol - paleudult ) and in plants (lettuce - Lactuca sativa L.; and beets Beta vulgaris L.) of the green belt of great São Paulo.

The waste compost applications were made from 1982 through 1989 and from 1994 through 1997 in haplaquents and in 1989 and from 1994 through 1997 in paleudult at a rate of $200 \mathrm{~m}^{3} \mathrm{ha}^{-1}$ year $^{-1}$ (80 $\mathrm{Mg} \mathrm{ha}^{-1}$ year $^{-1}$ - dry basis).

On a first step one collected soil and plant samples were collected in areas cultivated with lettuce and beets and soil samples in neighboring uncultivated areas covered by grass, without any waste compost application.

After, samples were collected from areas cultivated with lettuce in haplaquents in the same place as that of the first step and in two other neighboring places that had never received waste compost application.

The soil went evaluated through micromorphological (electronic microscope analysis associated with semiquantitative chemical analysis), microbiological (biomass and count of likely number of fungi and bacteria), physical (density and electrical conductivity) and chemical evaluations (fertility, microelements $\mathrm{B}, \mathrm{Cd}, \mathrm{Cr}, \mathrm{Cu}, \mathrm{Fe}, \mathrm{Mn}, \mathrm{Mo}, \mathrm{Ni}, \mathrm{Pb}$ and $\mathrm{Zn}$ - total and extractable contents in DTPA, sequential extraction) and also of these elements in plants.

The results for micromorphological, microbiological and physical parameters showed that, except for the electrical conductivity, the waste 
compost application did not result in outstanding differences between the treated and non-treated areas.

The waste compost application increased the soil fertilities with a rise of $\mathrm{pH}$ associated with a decreasing of $\mathrm{H}+\mathrm{Al}$ values and increasing of CTC and percentage of soil bases saturation.

As to the total and extractable contents in DTPA of microelements in soils, $\mathrm{Cu}$ and $\mathrm{Zn}$ were wich presented the highest increment in treated area with waste compost relationship with the uncultivated areas in both soils and cultivated neighboring places in haplaquents that had never received waste compost application. The total contens were within the range of contents found under natural conditions for soils in the state of São Paulo.

The sequential extraction was performed using the samples collected on the first step. For most of the samples the microelements studied ( $\mathrm{Cd}, \mathrm{Cr}, \mathrm{Cu}$, $\mathrm{Fe}, \mathrm{Mn}, \mathrm{Ni}, \mathrm{Pb}$ and $\mathrm{Zn}$ ) were found mainly in residual fraction, except for $\mathrm{Mn}$. In compost treated areas $\mathrm{Cu}$ was more associated with the organic matter and $\mathrm{Zn}$ was more associated with the oxides in both soils. In the paleudult the $\mathrm{Cu}$, in addition to the organic fraction, was associated with the oxides and present in residual fraction, as well.

The contents observed in plant tissues were below the contents considered as phytotoxic, except for $\mathrm{Cr}$ and $\mathrm{Cu}$ in some samples, and no external symptom was observed. In the distribution on plants (roots, shoots and leaves), the microelements were more concentrated in the roots but strong varibility was observed. The physiological differences between the species do not allow extrapolation, mainly between plants which the edible part is that of the top part to plants with edible roots. In some of the compost-treated soil samples, $\mathrm{Pb}$ contents in the plants were above that allowed for human consumption. 


\section{INTRODUÇÃO}

A reciclagem de restos orgânicos urbanos no Brasil é ainda muito pequena frente à quantidade de resíduos produzida. Praticamente todo 0 lodo orgânico gerado nas estações de tratamentos de esgotos têm sido encaminhado aos aterros sanitários e quanto aos resíduos sólidos domiciliares estima-se que, no Estado de São Paulo, apenas cerca de $1 \%$ seja aproveitado pela agricultura, sendo o restante também destinado aos aterros ou lixões. A região da Grande São Paulo, a maior concentração urbana do país, com aproximadamente 15 milhões de habitantes, gera diariamente cerca de 10500 Mg de resíduos sólidos urbanos, dos quais mais de $50 \%$ são restos orgânicos (IPT, 1995; CETESB, 1999).

Entre as dificuldades para 0 aproveitamento dos residuos sólidos urbanos na agricultura podem ser citadas a necessidade de investimentos para construção e operação adequadas de usinas de compostagem, a viabilização do transporte e a qualidade do composto produzido.

Vive-se então um círculo vicioso: o comprometimento da qualidade inibe uma maior demanda, que inibe maiores investimentos $e$, a falta de investimentos, não permite a melhoria da qualidade do composto.

No que diz respeito 'a qualidade, uma das principais preocupações é a presença de elementos químicos potencialmente tóxicos.

Os microelementos $\mathrm{Cd}, \mathrm{Cr}, \mathrm{Cu}, \mathrm{Fe}, \mathrm{Mn}, \mathrm{Mo}, \mathrm{Ni}, \mathrm{Pb}$ e $\mathrm{Zn}$ (presentes em concentrações da ordem de $\mathrm{mg} \mathrm{kg}^{-1}$ ) pelo seu potencial 
acumulativo no solo, além de representarem risco para a cadeia trófica, algumas vezes de difícil detecção, podem diminuir a resistência e resiliência ${ }^{1}$ dos solos agrícolas (Ross, 1994b; Hill \& James, 1995; Karlen et al, 1997 ).

Um termo bastante usado para designar estes elementos é o de "metais pesados", cujas densidades devem ser maiores que 5,0 ou $6,0 \mathrm{~g} \mathrm{~cm}^{-3}$ (Phipps, 1981; Coker \& Matthews, 1983), expressão essa muitas vezes usada de forma pejorativa, ou como sinônimo de "metal tóxico". A combinação "meio ambiente" e "metais pesados" normalmente alcança atenção emotiva da mídia (Coker \& Matthews, 1983), embora a toxicidade de um determinado elemento químico não seja uma qualidade inerente do mesmo, estando mais freqüentemente associada à sua concentração (Laskowski, 1991; Alloway \& Ayres, 1997; Chaney et al., 1998 ).

Os materiais e os processos que determinam os teores de microelementos no composto de resíduos sólidos urbanos (CRSU) foram detalhados por Rosseaux et al. (1989) e Egreja Filho (1993). As contaminações de $\mathrm{Cd}$, por exemplo, são originadas de materiais de uso recente (baterias: $30 \%$; plásticos: $70 \%$ ). Por outro lado, após sinais de alerta a partir do início da década de 70 , com os trabalhos de Rufus Chaney e colaboradores, a qualidade dos compostos orgânicos produzidos a partir de resíduos urbanos tem melhorado, visando aproveitar os seus aspectos benéficos e a presença de microelementos em níveis potencialmente tóxicos tem sido reduzida (Logan, 1995). Outro atenuante é o comportamento do sistema solo-planta, freqüentemente limitando o estabelecimento de teores zootóxicos nos vegetais (Chaney, 1998 ).

Um dos argumentos principais para rejeitar a utilização de fertilizantes produzidos a partir de residuos urbanos em culturas agrícolas, principalmente as de consumo direto, seria a hipótese da "bomba relógio quimica", que considera os riscos potenciais da saturação dos sítios de

\footnotetext{
${ }^{1}$ Resistência: magnitude de distúrbio que o sistema solo pode absorver sem que sua estrutura seja modificada. Resiliência: capacidade do solo de retornar a estado de equilibrio dinâmico inicial (elasticidade). (Seybold et al., 1999).
} 
adsorção e, no caso da queda no teor de matéria orgânica ao longo do tempo, proporcionar uma maior biodisponibilização dos microelementos (Adriano, 1986; Alloway \& Ayres, 1997; Chang et al, 1997; Dudka \& Adriano, 1997). Por outro lado, a hipótese da "barreira do sistema solo-planta" pondera que diversos mecanismos podem limitar a absorção de microelementos potencialmente tóxicos a um determinado platô ou reduzir sua biodisponibilidade ao longo do tempo (Coker \& Matthews, 1983; Matthews, 1984; Kuo, 1986; McGrath, 1987; Chaney, 1990 $\mathrm{ab}$; Essington \& Mattigod, 1991; Chaney, 1994; Chaney et al., 1994; Brown et al., 1998).

Alguns experimentos para avaliar a capacidade das plantas de absorver microelementos têm sido feitos em ensaios de vaso de curta duração, em casa de vegetação, utilizando-se sais para o fornecimento de doses controladas dos elementos químicos estudados ou ainda materiais orgânicos enriquecidos com microelementos. No entanto, tais procedimentos podem superestimar a absorção das plantas, conduzindo a resultados que não correspondem a realidade (De Vries \& Tiller, 1978; Behel et al., 1983; Valdares et al., 1983; Chaney, 1990a; Chaney, 1990b; Bell et al, 1991; Chaney 1994; Chaney et al., 1994; EPA, 1995; Candelaria \& Chang, 1997; Brown et al. 1998). A biodisponibilidade de um determinado elemento é diferente quando o teor a ser avaliado é fornecido em uma única ou em múltiplas aplicações (Behel, 1983; Coker \& Matthews, 1983; Wilke, 1991), limitando a utilização de materiais orgânicos enriquecidos com microelementos para simulação de doses de longo prazo.

Os experimentos realizados com CRSU e com biossólidos (lodo de esgoto) em diversos países, para verificar a biodisponibilidade de microelementos dão indícios da necessidade de experimentos de campo de longa duração. Estes ensaios, via de regra, não têm sido realizados no Brasil. Dados sobre avaliações de campos cultivados com aplicações de longa duração de lodo de esgoto ou CRSU no país são escassos (Jorge et al., 1991; Lima et al. 1995; Bissani et al. 1997; Collier et al. 1997; Lima \& Menk, 1997), 
embora no caso do CRSU, as usinas de compostagem tenham começado a operar nas décadas de 60 e 70 (Brasilia, 1963; Maceió, 1968; São Paulo, 1970; Belém, 1974; Rio de Janeiro, 1975 - Composting, 1984).

Visando contribuir para preencher esta lacuna, o presente trabalho foi realizado em condições de cultivo comercial, com o objetivo de investigar os riscos de contaminação e o potencial poluente ${ }^{1}$ da aplicação do composto em áreas agrícolas de cultivo de hortaliças.

Foram estudados, na região do cinturão verde da Grande São Paulo, um solo glei húmico, onde se aplicou composto de resíduos sólidos urbanos (CRSU) de 1982 a 1989 e de 1994 a 1997 e um solo podzólico vermelho-amarelo, que recebeu aplicações de composto em 1989 e de 1994 a 1997, na taxa de $200 \mathrm{~m}^{3} \mathrm{ha}^{-1} \mathrm{ano}^{-1}$ (80 Mg ha ${ }^{-1}$ ano $^{-1}$ - base seca).

Os efeitos da aplicação do composto em alguns atributos do solo (micromorfologia, atividade microbiológica, densidade e condutividade elétrica), foram avaliados, como também verificados os teores e o comportamento de alguns microelementos (acumulação, biodisponibilidade e associação com os diferentes compartimentos do solo - trocável, ligado aos carbonatos, aos óxidos, à matéria orgânica e à fração residual), e também a absorção e distribuição em plantas de alface (Lactuca sativa L.) e beterraba (Beta vulgaris L.), comparando-se os teores observados com os limites toleráveis.

\footnotetext{
1 Contaminante: elemento fora do seu local de origem, em concentração acima do normal, o que não implica necessáriamente na existência de efeitos adversos.

Poluente: elemento contaminante que causa efeitos adversos em um ou mais organismos.

(Pierzynski et al., 1994)
} 


\section{REVISÃO DE LITERATURA}

\subsection{Destinação do composto de resíduos sólidos urbanos (CRSU)}

Em função de aspectos sócio-econômicos e culturais a produção de resíduos sólidos urbanos, varia quantitativa, qualitativa, e geograficamente, ao longo do tempo. Nas cidades brasileiras, a taxa de geração por habitante varia de 0,4 a $0,7 \mathrm{~kg} \mathrm{dia}^{-1}$ (Polprasert, 1989; Daxbeck \& Brunner, 1992; Brunner \& Baccini, 1992; Figueiredo, 1994; CETESB, 1999).

Verificou-se que a composição dos resíduos sólidos na cidade de São Paulo (SP) variou ao longo do tempo. A presença do plástico só foi registrada a partir de 1969, $19 \mathrm{~g} \mathrm{~kg}^{-1}$, e em 1993 chegou a $120 \mathrm{~g} \mathrm{~kg}^{-1}$. A participação de materiais orgânicos em 1927 era de $825 \mathrm{~g} \mathrm{~kg}^{-1}$ e em 1993 de $644 \mathrm{~g} \mathrm{~kg}^{-1}$. O teor de materiais orgânicos nos resíduos das cidades brasileiras varia de 550 a $900 \mathrm{~g} \mathrm{~kg}^{-1}$. Em países mais industrializados a fração orgânica dos resíduos urbanos é menor que $500 \mathrm{~g} \mathrm{~kg}^{-1}$ (Polprasert, 1989; Rosseaux et al, 1989; IPT, 1995).

A forma de tratamento de resíduos urbanos mais utilizada no Brasil tem sido a disposição em aterros sanitários. No caso do Estado de São Paulo, de um total de 645 municípios (608 aterros ou lixões e 12 usinas de compostagem), para $56,4 \%$ deles a disposição é considerada inadequada (CETESB, 1999). O crescimento das cidades e o aumento na produção de residuos têm provocado a saturação de aterros localizados em terrenos mais próximos aos centros urbanos e com condições mais adequadas para o controle 
de líquidos percolados, aumentando o risco de contaminação de aqüíferos e elevando o custo desta forma de destinação (He et al., 1992; Parr \& Hornick, 1993; Figueiredo, 1994; Stratton et al, 1995).

A contaminação de aquíferos pode se dar pela alteração da composição e atividade de sua microbiota ou ainda pela lixiviação de elementos indutores de alcalinidade, formas nitrogenadas, etc, principalmente em regiões de rochas mais permeáveis (Menezes, 1994; Alvarez, 1997, Ludvigsen, 1999).

Para destinação dos resíduos urbanos em países europeus tem sido recomendada a incineração, visando o aproveitamento da energia liberada ou simplesmente a diminuição do volume (Brunner \& Baccini, 1992). No entanto, a tecnologia necessária para o controle das emissões de incineradores é onerosa e de eficácia questionável, sendo que, $90 \%$ do $\mathrm{Cd}$ e $95 \%$ do $\mathrm{Hg}$ presentes em resíduos incinerados são perdidos na forma de gases e particulados (Matthews, 1984; Alloway \& Ayres, 1997). Além disso, um fato a ser considerado é o aumento da concentração de microelementos potencialmente tóxicos nas cinzas em relação ao residuo incinerado (Rosseaux et al., 1989) e os riscos de sua disposição final em aterros sanitários pois, além dos elementos ficarem mais concentrados, se apresentam em formas mais solúveis (Hutton \& Symon, 1987).

O aumento da concentração de elementos tóxicos em relação aos sítios de adsorção ou a formação de complexos podem provocar o incremento da mobilidade destes elementos. (Lund et al., 1976; Matthews, 1984; Lun \& Christensen, 1989; Sígolo \& Assunção, 1995; Sígolo \& Mello Jr., 1995; Amarante, 1997; Naidu et al., 1997; Mello Jr., 1998). O lixiviado de aterros sanitários (chorume), por exemplo, normalmente tem altas concentrações de $\mathrm{Cl}^{-} \mathrm{e}$, então, muitos metais podem estar presentes na forma de complexos clorados, que, freqüentemente, são muito mais móveis e menos adsorvidos do que formas catiônicas livres (Alloway, 1995). Os riscos de contaminação da água subterrânea quando da destinação de resíduos é maior 
em regiōes de aqüíferos fissurados (Matthews, 1984), como é o caso da região metropolitana de São Paulo.

A implantação de legislação mais rigorosa para proteção da água subterrânea deverá favorecer a implantação de novas usinas de reciclagem de resíduos urbanos, em detrimento dos aterros sanitários como forma exclusiva de destinação (He et al., 1992; Parr \& Hornick, 1993; Figueiredo, 1994; Stratton et al, 1995).

A opção pela utilização agricola da fração orgânica dos residuos urbanos, entre outros fatores, tem sido truncada por preocupações com a presença de elementos contaminantes com potencial poluente, principalmente com relação aos microelementos potencialmente tóxicos, amplamente relatados na literatura (Jardim, 1983; Scheinberg \& Smoler, 1990; Watson, 1990; Berton \& Valadares, 1991; Taylor, 1991; Hammer, 1992; Hovi, 1992; Miller et al., 1992; Prince, 1992; Berton, 1993; Grossi, 1993; Egreja Filho, 1993; Taylor, 1993; Malavolta, 1994; Cravo, 1995; Cravo et al., 1998).

\subsection{Microelementos na agricultura}

Geralmente as concentrações naturais de microelementos no solo estão na faixa de $\mathrm{mg} \mathrm{kg}^{-1}$ ou $\mu \mathrm{g} \mathrm{kg}^{-1}$, sendo estes teores normalmente suficientes para suprir as necessidades dos diversos organismos presentes no sistema. Existem, porém, aqueles que não exercem nenhuma função conhecida no ciclo biológico e suas baixas concentrações muitas vezes dificultam a sua determinação analítica.

Entre os termos utilizados para designar os microelementos temos o de "elementos traços", que teve origem na química clássica, devido às dificuldades analíticas para sua determinação que, em alguns casos, persistem até hoje (Phipps, 1981). Esta denominação é utilizada por alguns clássicos da literatura sobre o assunto (Adriano, 1986; Kabata-Pendias \& Pendias, 1992). 
Outra denominação muito utilizada para microelementos potencialmente tóxicos é a de "metais pesados" (Lepp, 1981; Alloway, 1995). Existem autores que definem metal pesado como sendo aquele cuja densidade ultrapassa determinado limite como, por exemplo, $5,0 \mathrm{~g} \mathrm{~cm}^{-3}$ (Coker \& Matthews, 1983) ou $6,0 \mathrm{~g} \mathrm{~cm}^{-3}$ (Phipps, 1981). Jardim (1983) considera o termo metal pesado como incorreto, pois, segundo ele, não caracteriza um número definido de metais, sendo geralmente usado para os seguintes elementos: $\mathrm{Ag}, \mathrm{As}, \mathrm{Cd}, \mathrm{Cr}, \mathrm{Cu}, \mathrm{Fe}$, $\mathrm{Hg}, \mathrm{Mn}, \mathrm{Ni}, \mathrm{Pb}, \mathrm{Sn}, \mathrm{Ti}, \mathrm{V}$ e Zn.

No presente trabalho, embora a maioria dos elementos estudados ( $\mathrm{B}, \mathrm{Cd}, \mathrm{Cr}, \mathrm{Cu}, \mathrm{Fe}, \mathrm{Mn}, \mathrm{Mo}, \mathrm{Ni}, \mathrm{Pb}$ e $\mathrm{Zn}$ ) possam ser classificados como metais pesados, a opção pela uso da terminologia "microelementos" deveu-se ao fato de que o termo "metal pesado" vem sendo associado apenas aos aspectos negativos destes elementos químicos.

O enfoque destes elementos na agricultura pode ser dividido em duas fases: uma primeira, abordando os elementos essenciais ao funcionamento fisiológico das plantas superiores, denominados então de micronutrientes e uma segunda fase, com enfoque nos microelementos potencialmente tóxicos.

A primeira fase da preocupação com os microelementos na agricultura pode ser considerada uma conseqüência do modelo de manejo da fertilidade do solo preconizado por Liebig (1864), baseado na utilização de fertilizantes minerais prontamente solúveis, e foi ampliada com a adoção de práticas preconizadas pela revolução verde para uma agricultura mais intensiva e, portanto, mais exportadora de nutrientes (Howard, 1943; Borlaug, 1972; Borlaug, 1973).

Com o cultivo mais intensivo, a implantação de monoculturas e a substituição das fontes orgânicas por adubos prontamente solúveis, de maior concentração em macronutrientes, para alguns solos mais pobres em 
fertilidade natural e para algumas culturas mais exigentes, pode-se observar uma deficiência induzida de micronutrientes.

Ashmead (1996) alerta para a queda no teor de alguns microelementos no milho cultivado nos Estados Unidos e as suas implicações na nutrição humana ( $\mathrm{Cu}$, menos 68\%) enquanto que Schutte (1964) correlacionou a distribuição irregular de câncer no estômago, com a distribuição de solos com alto conteúdo de matéria orgânica, resultando em deficiências de $\mathrm{Cu}$.

A segunda fase na abordagem dos microelementos em agroecossistemas, diz respeito às preocupações com a presença de teores mais elevados, devido a fontes antropogênicas diversas (emissões atmosféricas, pesticidas, água de irrigação, corretivos, fertilizantes orgânicos e inorgânicos) (Adriano, 1986; Alloway, 1995).

\subsection{Os agroecossistemas e a aplicação de CRSU}

Deve-se ter em mente que agroecossistemas são sistemas abertos que recebem insumos de fora e exportam produtos, sendo afetados pela qualidade do ambiente. Segundo Altieri (1989), cada região tem um grupo único de agroecossistemas que resultam de variações locais no clima, solo, relações econômicas, estrutura social e história. O conceito de agroecossistemas é, portanto, mais abrangente que o de sistemas solo-planta.

Face às influências que o clima e natureza do solo $(\mathrm{pH}$, drenagem e sobretudo a textura) exercem sobre os processos de humificação, mineralização e taxa de renovação do carbono do solo (Uehara \& Gillman, 1981; Fassbender, 1987; Cerri et al, 1996), principalmente para solos de cargas variáveis como é o caso das regiōes tropicais, com a CTC dependendo dos teores de matéria orgânica e pH (Verdade, 1956; van Raij, 1967; Santos Filho, 
1985; Prata et al., 1996), a utilização agrícola é uma alternativa promissora para o aproveitamento dos resíduos orgânicos urbanos (Berton \& Valadares, 1991).

O CRSU pode ser considerado um fertilizante orgânico com baixo teor em nutrientes em relação à demanda das plantas cultivadas (van Raij et al., 1996; Chitolina, 1998a), chegando a ser aplicado em doses da ordem de 20 a $30 \mathrm{Mg} \mathrm{ha}^{-1}$ (base seca), com uma freqüência de quatro a cinco vezes por ano. Este aspecto, associado ao fato da localização de sua produção se concentrar nos grandes centros urbanos, encarece o transporte deste insumo para as áreas de produção agrícola, fazendo com que o CRSU produzidos pelas usinas de compostagem da região metropolitana sejam consumidos principalmente nas áreas agrícolas mais próximas. A utilização em altas doses aumenta o risco dos microelementos potencialmente tóxicos exercerem efeitos poluentes. O comportamento acumulativo destes elementos na superfície do solo, já verificado por diversos autores (Williams \& David, 1973; Lund et al., 1976; Matthews, 1984; Brams \& Anthony, 1988; Lun \& Christensen, 1989; Sígolo \& Assunção, 1995; Sígolo \& Mello Jr., 1995; Bertoncini, 1997; Naidu et al, 1997; Martin \& Kaplan, 1998), justifica a necessidade do levantamento das áreas que já utilizaram o CRSU para averiguar quais os efeitos da utilização prolongada do composto.

\subsection{Efeitos da utilização do CRSU em agroecossistemas}

\subsubsection{Efeitos da utilização do CRSU no solo}

\subsubsection{Efeitos em atributos micromorfológicos}

A determinação micromorfológica através da microscopia eletrônica de varredura associada a análise química semi-quantitativa por espectrometria de energia dispersiva tem sido utilizada para avaliação de 
neoformações em áreas contaminadas (Mattigod et al., 1986; Amarante, 1997; Mello Jr. 1998). As neoformações seriam indícios de uma tendência a tamponamento da composição de elementos biodisponíveis do sistema solo em estratégia semelhante à homeostase (Cardoso, 1992 $\mathrm{a}, \mathrm{b}$ ), princípio pelo qual o ecossistema tende a manter a sua composição biótica relativamente constante.

Amarante (1997) e Mello Jr (1998), trabalhando em aterro contaminado constataram a presença de $\mathrm{Mn}$ associado a minerais neoformados (barita e apatita); nódulos metálicos de $\mathrm{Fe}, \mathrm{Cr}$ e $\mathrm{Ni}$; minerais de ferro com $\mathrm{Zn}$ associado e estruturas de forma esférica, com inúmeras cavidades, provavelmente de origem orgânica, que em perfis contaminados revelou-se uma armadilha para os microelementos.

O uso da avaliação micromorfológica para averiguar os efeitos da aplicação de CRSU no solo não foi encontrada na literatura.

\subsubsection{Efeitos em atributos microbiológicos}

Ao estudarmos o efeito do CRSU sobre a microbiota em condições de campo é importante considerarmos também as influências de outras práticas agrícolas, tais como: cultivo intensivo, utilização de fertilizantes minerais e corretivos, aplicação de pesticidas (Dahlin et al., 1997; Kennedy \& Gewin, 1997; Ananyeva et al., 1999; Bardgett \& McAlister, 1999; Marchiori Jr. \& Mello, 1999; Simek et al, 1999).

Diversas substâncias orgânicas tóxicas podem estar presentes em campos cultivados tais como as bifenilas policloradas (PCBs); os hidrocarbonetos aromáticos policíclicos (PAHs) e as dioxinas (dibenzo-pdioxinas policloradas - PCDDs e dibenzofuranas policloradas - PCDFs). Como principais fontes destas substâncias temos a incineração de resíduos, capazes de contaminar as áreas agrícolas de forma indireta e difusa, propagando-se por áreas extensas, e a aplicação de herbicidas, capazes de 
contaminar os campos cultivados de forma direta (Pierzynski et al., 1994; Alloway \& Ayres, 1997). Grossi (1993), avaliando o CRSU produzido em diversas cidades brasileiras verificou que o composto também pode ser uma importante fonte destas substâncias orgânicas tóxicas, mas sua determinação em análises de monitoramento pode ser limitada pelo seu custo elevado.

Nas diversas avaliações químicas de usinas de compostagem com relação aos riscos do composto exercer efeitos poluentes, apenas os microelementos potencialmente tóxicos têm sido determinados (Freedman \& Hutchinson, 1981; Haan, 1981; Cabrera et al., 1989; Rosseaux et al., 1989; Berton \& Valadares, 1991; He et al.; 1992; Hernandez et al., 1992; Grossi, 1993; He et al., 1995; Peverly \& Gates, 1994; Cravo, 1995; Pressinoti \& Fernandez Jr., 1995; Abreu et al., 1996; Ayuso et al., 1996; Chitolina, 1998; Cravo et al., 1998; Marchiori et al., 1998).

Determinações microbiológicas de solos tratados com CRSU, em complemento a avaliações de microelementos potencialmente tóxicos são importantes pois, podem permitir detectar indícios da presença de elementos e/ou substâncias contaminantes que não as escolhidas para a análise química. Além disto, cabe salientar que mesmo concentrações de microelementos abaixo dos limites permitidos podem vir a causar efeitos depressivos na microbiota, conforme verificado por Dahlin et al. (1997) para populações de rizóbio em relação aos limites para microelementos potencialmente tóxicos estabelecidos pela união européia. Entretanto, a aplicação de CRSU pode favorecer a fixação biológica de nitrogênio em leguminosas (atividade da nitrogenase, tamanho e número de nódulos), promovendo o aumento na produção de matéria seca (Peixoto et al., 1987 e Santos et al., 1992)

A adição de CRSU proporciona um incremento na disponibilidade de nutrientes e de substrato carbônico, o que pode mascarar 0 efeito de metais na biomassa microbiana, que só vem a ser afetada quando 
ocorre a contaminação com teores de microelementos elevados, como por exemplo, $1000 \mathrm{mg} \mathrm{kg}^{-1}$ de Cu ou Zn (Brookes, 1995; Dahlin et al.,1997).

Segundo Macnaughtom et al. (1999) a aplicação de microelementos em concentrações tóxicas pode induzir rápidas mudanças na comunidade microbiana. No entanto, é importante frisar que estes autores utilizaram concentrações de $\mathrm{Cd}$, Co e $\mathrm{Sr}$ de $500 \mathrm{mg} \mathrm{kg}^{-1}$, adicionados na forma de sais e, portanto, com disponibilidade muito superior a normalmente encontrada no CRSU.

Mesmo para fertilizantes orgânicos contendo teores elevados de metais, passado um determinado periodo de depressão da biomassa, após sua aplicação ao solo, a redução da atividade de uma população menos tolerante a alteração das condições ambientais pode ser compensada pelo aumento de outras, mais adaptadas às novas condições (Giller et al., 1998; Roane, 1998; Moreno et al., 1999). Todavia, alguns resultados de estudos ecotoxicológicos têm associado mudanças na estrutura das populações microbianas com decréscimos na biomassa da comunidade edáfica (Frostegard et al., 1993; Frostegard et al., 1996).

A condução de ensaios de longa duração é essencial porque algumas propriedades do solo mudam lentamente e por vezes são de difícil detecção (Seybold et al., 1999; McGrath \& Chaudri, 1999). Pouco avanço científico é alcançado por resultados obtidos em laboratório que não podem ser conectados com efeitos que ocorrem no campo ou, quando os mecanismos responsáveis pelos fenômenos observados não são esclarecidos (De Vries et al. 1978; Giller et al., 1998).

Flutuações populacionais de bactérias em condições de campo com depressões maiores que $90 \%$ do total da comunidade bacteriana ocorrem freqüentemente, causados pelo uso de insumos, flutuações de temperatura, potencial de água, $\mathrm{pH}$, distúrbios físicos. Quando a população se recupera num prazo de 30 dias a flutuação pode ser considerada normal, num prazo de 30 a 
60 dias, aceitável e, acima deste intervalo, pode ser considerada crítica (Domsch et al., $1983^{6}$, citados por Brookes, 1995).

Juntamente com a biomassa, as transformações de $\mathrm{N}$ são consideradas as atividades microbianas mais sensiveis às mudanças ambientais (Brookes, 1995). Por exemplo, mudanças na estrutura da comunidade microbiana podem ser causados por diferentes graus de tolerância ao $\mathrm{Cu}$, um dos elementos de maior participação na dinâmica do $\mathrm{N}$ (Dahlin et al., 1997; McCarty, 1999).

Baath (1989) alerta que mesmo processos biológicos mais sensitivos como as transformações do nitrogênio só começam a ser afetados quando atingidas concentrações três vezes superiores aos valores do solo tomado como referência. Em áreas contaminadas com teores de $\mathrm{As}, \mathrm{Cr}$ e $\mathrm{Cu}$ superiores a $1000 \mathrm{mg} \mathrm{kg}^{-1}$, Bardgett et al. (1994) não observaram qualquer alteração na mineralização do $\mathrm{N}$ e Yeates et al. (1994) verificaram que, para teores de 12 a $835 \mathrm{mg} \mathrm{kg}^{-1}$ destes metais, embora tenham sido observadas taxas de nitrificação mais lentas nos solos mais contaminados, todo $\mathrm{N}$ mineral do solo foi encontrado como $\mathrm{NO}_{3}{ }^{-}$após 14 dias de incubação. Estes autores consideraram que, em ensaios de longa duração, bactérias tolerantes ao $\mathrm{As}, \mathrm{Cr}$ e Cu podem ser selecionadas.

Como conseqüência da elevada diversidade, atividades microbianas podem ser consideradas altamente redundantes (com exceção da nitrificação). Além disto, os elementos potencialmente tóxicos podem sofrer biosorção ou serem dispersos no ambiente pela ação da biota, o que pode aumentar a resistência e resiliência do sistema (Ineson \& Anderson, 1985; Beare et al., 1995; Ehrlich, 1997).

O elevado número de fatores que interferem na biodisponibilidade dos microelementos para a microbiota se refletem nas

${ }^{6}$ DOMSCH, K.H.; JAGNOW, G.; ANDERSON, T.H. An ecological concept for the assessment of side-effects of agrochemicals on soil micro-organisms. Res. Ver. v. 86, p. 65-105. 1983. 
grandes diferenças entre os limites considerados tóxicos verificados na revisão feita por Baath (1989).

Um aspecto importante a ser ressaltado com relação à microbiologia do solo e a aplicação de CRSU é que a diminuição dos teores de matéria orgânica em solos cultivados por muitos anos pode aumentar a incidência de fungos causadores de doenças nas raizes (Igue \& Pavan, 1984; Cardoso, 1992 $\mathrm{a}, \mathrm{b}$ ) e que a utilização do CRSU pode reduzir a ocorrência de algumas doenças, conforme verificado por Ceuster \& Hoitink (1999).

Com relação à presença de agentes patogênicos no CRSU, Pereira Neto \& Stentiford (1991) e Fortes Neto \& Selbach (1996) verificaram que a compostagem adequada é um processo eficiente para sua eliminação.

\subsubsection{Efeitos em atributos físicos}

A melhoria de atributos físicos como a densidade do solo, capacidade de retenção de água, estruturação do solo e a porosidade é tida como um dos principais benefícios da adubação orgânica para o aumento da produtividade agrícola (Kiehl, 1985).

Pinamonti et al., (1995) verificaram a melhoria de características físicas do solo relacionadas à temperatura e umidade, através da aplicação em cobertura de CRSU em frutíferas.

Khaleel et al. (1981) e Jorge et al. (1991) alertam para a escassez de informações sobre alterações em atributos físicos do solo motivados pela aplicação de resíduos orgânicos. Estes autores consideraram a determinação da densidade um parâmetro de pouca precisão uma vez que, por exemplo, não diferencia macro e microporosidade. $A$ avaliação da condutividade hidráulica conforme realizada por Jorge et al. (1991) é um parâmetro que permite uma melhor diferenciação entre diferentes tratamentos ou formas de manejo. 
Um aspecto físico-químico muito importante no que diz respeito a aplicações de CRSU no solo são os efeitos causados sobre a condutividade elétrica.

As alterações na condutividade elétrica provocada por adubos orgânicos é bastante variável, em função da sua composição, das dosagens utilizadas e do balanço hídrico do agroecossistema (Igue \& Pavan, 1984).

Segundo Berton (1997), mesmo na dosagem de $80 \mathrm{Mg} \mathrm{ha}^{-1}$ de

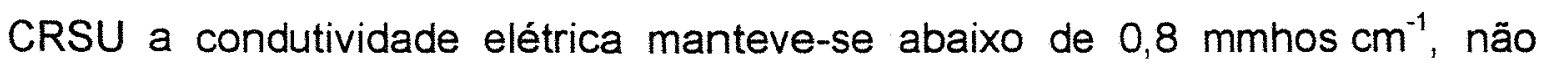
devendo, assim, prejudicar a germinação das sementes e nem o crescimento inicial das plantas. Entretanto, Prado Filho (1986) alerta que aplicações de doses elevadas de composto $\left(160-240 \mathrm{Mg} \mathrm{ha}^{-1}\right)$ podem provocar a salinização do solo, causada principalmente pelo ion $\mathrm{K}^{+}$. Costa (1994) trabalhando com vasos em casa de vegetação, verificou que a dose de $90 \mathrm{Mg} \mathrm{ha}^{-1}$ de CRSU provocou um aumento de cerca de sete vezes na condutividade elétrica em relação aos solos não tratados. Este autor considerou 0 aumento excessivo na concentração salina como um dos principais efeitos da aplicação do CRSU nos solos estudados.

\subsubsection{Efeitos em atributos químicos do solo}

\subsection{Aspectos gerais relativos à fertilidade do solo}

O teor de matéria orgânica do CRSU pode ser considerado sua característica de maior interesse agrícola, pois além de atuar na melhoria das propriedade físicas do solo e ser fonte de energia para a biota, também pode contribuir para o aumento da CTC do solo e fornecimento de nutrientes.

As maiores participações da matéria orgânica na CTC ocorrem em solos arenosos e os maiores teores de matéria orgânica são encontrados nos solos argilosos. Espera-se que os efeitos benéficos nas propriedades físicas sejam mais pronunciados em solos argilosos e os efeitos nas 
propriedades químicas e físico-químicas sejam maiores nos solos arenosos, mais pobres em nutrientes e menos conservadores da matéria orgânica (Verdade, 1956; van Raij, 1967; Santos Filho, 1985 e Prata et al., 1996).

A grande importância da matéria orgânica para a CTC nos solos de carga variável que ocorrem em regiões tropicais é reflexo da baixa atividade da fração argila destes solos (Uehara \& Gillman, 1981; Fassbender \& Bornemisza, 1987).

Embora a matéria orgânica possa causar redução nos valores de $\mathrm{pH}$ através da dissociação de ácidos orgânicos solúveis (Ritchie \& Dolling,1985), normalmente o uso de resíduos urbanos causa a redução da acidez. Com relação aos efeitos da aplicação de CRSU no pH e no alumínio trocável, Mazur et al. (1983) e Peixoto et al. (1987) verificaram que o composto promoveu uma elevação do $\mathrm{pH}$, atribuindo o fato a uma possível complexação do alumínio trocável. Destacaram também a importância do composto no fornecimento de cálcio.

Desde que os fertilizantes orgânicos sejam utilizados de forma adequada, o fornecimento de $\mathrm{N}$ pode ser considerado um de seus principais benefícios. Para isso é preciso buscar sincronizar as ofertas dos diferentes compartimentos do solo com as demandas fisiológicas das plantas, estimulando concomitantemente os organismos benéficos, de forma a melhorar os balanços energético e econômico (Anderson \& Ingram, 1993; Woomer \& Swift, 1994).

Embora os resíduos orgânicos possam conter quantidades apreciáveis de $\mathrm{N}$, dependendo da forma em que este se encontra, ou, ainda, dependendo da composição dos resíduos, este nutriente pode apresentar perdas consideráveis durante o processo de compostagem (Trani, 1981). Mesmo que o CRSU maturado seja rico em nitrogênio, é importante verificar a forma em que ele se encontra e a sua biodisponibilidade, a fim de evitar que a sua imobilização limite a produção agrícola, como foi observado por Spiers et al.(1996). 
A maturidade do composto, que pode ser definida como sendo o grau de estabilidade de suas propriedades físicas, biológicas e químicas (He et al., 1992; He et al., 1995), é um fator importante que pode determinar o êxito de sua aplicação na agricultura. A aplicação de compostos imaturos no solo pode causar deficiências de $\mathrm{N}$ às plantas devido a imobilização do elemento ou mesmo toxicidade pelo excesso de $\mathrm{NH}_{3}$ liberado (Sinha, 1975). Pode também causar um decréscimo na concentração de $\mathrm{O}_{2}$ e no potencial redox, aumentando a biodisponibilidade de alguns microelementos potencialmente tóxicos (Cottenie, 1981, citado por Cravo, 1995). Já o excesso de $\mathrm{N}$ pode provocar perdas por volatilização ou por lixiviação (Cassman \& Munns, 1980; Hsieh et al., 1981; Lindermann \& Cardenas, 1984; Barbarika et al., 1985; Serna \& Pomares, 1992).

A disponibilização de $\mathrm{N}$ para as culturas dependerá da taxa de mineralização do material orgânico. Em experimento conduzido por Spiers et al. (1996), embora a quantidade aplicada de CRSU tivesse significado um maior aporte de $\mathrm{N}$ por área do que o esterco de galinha (444 $\mathrm{kg} \mathrm{ha}^{-1}$ contra $426 \mathrm{~kg} \mathrm{ha}^{-1}$ ), devido a sua taxa de mineralização mais lenta, sua liberação de $\mathrm{N}$ para a solução do solo só superou o esterco de galinha após seis meses da aplicação. Este comportamento diminui o risco de lixiviação de nitratos e evita que a aplicação de CRSU provoque desequilíbrios nutricionais nas plantas, motivados pelo fornecimento de $\mathrm{N}$ em excesso, conforme já verificado em ensaios com lodo de esgoto e fontes de $\mathrm{N}$ prontamente solúveis por diversos autores (Cassman \& Munns, 1980; Hsieh et al., 1981; Lindemann \& Cardenas, 1984; Barbarika et al., 1985; Chaboussou, 1987; Serna \& Pomares, 1992).

O CRSU contém em média cerca de $12 \mathrm{~g} \mathrm{~kg}^{-1}$ de $\mathrm{N}$ (Carmo et al., 1998; Cravo et al. 1998), sendo seu potencial impactante, sob este aspecto, menor que fontes minerais prontamente solúveis $\left(200\right.$ a $450 \mathrm{~g} \mathrm{~kg}^{-1}$ - Malavolta, 1981). 
O CRSU pode intervir favoravelmente na dinâmica do fósforo no solo, seja através do incremento da enzima fosfatase, seja diminuindo a retenção por formas inorgânicas. A ação sinérgica entre o composto orgânico $e$ o fósforo ocorre notadamente quando o fósforo é adicionado na forma de superfosfato simples durante o processo de compostagem. (Trani, 1981; Peixoto et al., 1987; Peixoto 1988; Peixoto et al., 1989a; Peixoto et al., 1989b; Santos et al., 1992; Castillo et al., 1996; Rivero, 1996).

A contribuição em $\mathrm{Ca}, \mathrm{Mg}$ e $\mathrm{S}$ tem merecido pouca atenção nos trabalhos realizados com CRSU. Quanto ao K, sua presença no composto (2,4 a 7,8 $\mathrm{g} \mathrm{kg}^{-1}$ - Chitolina, 1998 ), juntamente com ○ $\mathrm{Na}$, tem sido discutida mais com relação ao seu potencial de incrementar a condutividade elétrica do que quanto ao seu efeito como nutriente (Costa, 1994; Santos, 1995).

\subsection{Efeitos em teores totais e biodisponiveis de microelementos}

Ao avaliarmos o efeito do CRSU nos teores de microelementos potencialmente tóxicos em condições de campo é importante não ser esquecido que os agroecossistemas são sistemas abertos e, portanto, sujeitos a diversas fontes de aporte destes elementos.

Fontes antropogênicas de microelementos potencialmente tóxicos

As principais fontes antropogênicas de microelementos potencialmente tóxicos no ambiente são fertilizantes, pesticidas, água de irrigação contaminada, combustão de carvão e óleo, emissões veiculares, incineração de residuos urbanos e industriais e, principalmente, mineração, fundição e refinamento (Tavares \& Carvalho, 1992).

Numa comparação de ordens de grandeza entre as principais fontes de Cd para campos cultivados Sauerbeck (1984) cita os seguintes 
valores: fertilizantes fosfatados, de 3 a $7 \mathrm{~g} \mathrm{ha}^{-1} \mathrm{ano}^{-1}$; o lodo de esgoto, de $10 \mathrm{a}>25 \mathrm{~g} \mathrm{ha}^{-1} \mathrm{ano}^{-1}$; e poeira e chuva, de $<3$ a $27 \mathrm{~g} \mathrm{ha}^{-1} \mathrm{ano}^{-1}$.

Vários trabalhos têm evidenciado a presença de microelementos potencialmente tóxicos como $\mathrm{Cd}, \mathrm{Pb}, \mathrm{Ni}$ e $\mathrm{Zn}$ em fertilizantes minerais e corretivos de acidez de solos (Fellemberg, 1980; Mortvedt, 1987). A ocorrência dos microelementos nestes insumos é devida a presença de minerais que os contêm nas rochas usadas como matéria-prima para a sua fabricação e, em menor extensão, pelo processamento das rochas. Segundo Mortvedt (1987), 60\% do Cd presente em adubos fosfatados provém da própria rocha fosfática utilizada na fabricação sendo as formas químicas deste elemento solúveis e prontamente disponiveis para as plantas.

A participação dos fertilizantes fosfatados no incremento dos teores de $\mathrm{Cd}$ pode variar, em função de sua origem geoquímica (de $<0,03$ a $200 \mathrm{mg} \mathrm{kg}^{-1}$ ), e também em função da taxa de aplicação destes adubos (Williams \& David, 1973; Mulla et al., 1980; Sauerbeck, 1984; Mortvedt, 1987).

Segundo Lake (1987a), os superfosfatos apresentam altíssimas concentrações de $\mathrm{Cd}$ e estima-se que o aporte deste microelemento, em razão dos fertilizantes fosfatados, é muito maior que a contribuição atribuída a lodos de esgoto. Fellemberg (1980) situa os teores de $\mathrm{Cd}$ em adubos fosfatados na faixa de 10 a $100 \mathrm{mg} \mathrm{kg}^{-1}$. Segundo este autor, pesquisas realizadas na Suíça e na Austrália apontaram tais fertilizantes como grandes poluidores do solo em relação a vários microelementos, havendo casos onde os teores de $\mathrm{Cd}$ no solo chegavam a $91 \mathrm{mg} \mathrm{kg}^{-1}$.

Os fertilizantes N-P-K utilizados no Brasil normalmente têm concentrações de $\mathrm{Cd}$ que são significativamente menores que as de outros países (de < 0,03 a 14,6 $\mathrm{mg} \mathrm{kg}^{-1}$ ), (Lagenbach \& Sarpa, 1985; Amaral Sobrinho et al., 1992; Cravo et al., 1998). Porém, uma das misturas N-P-K analisadas por Gabe \& Rodella (1999), apresentou teor elevado (112 $\mathrm{mg} \mathrm{kg}^{-1}$ ). 
Outra fonte de Cd para os solos cultivados é a utilização de corretivos. Matthews (1984) relata a ocorrência de solos na Inglaterra com teores de $\mathrm{Cd}$ superiores a $500 \mathrm{mg} \mathrm{kg}^{-1}$, em virtude de aplicações de calcário. Assim como para os fertilizantes fosfatados, os teores de Cd em corretivos pode ser muito variável em função de sua origem geoquímica ou processo de fabricação, no caso de resíduos. Amaral et al.(1994) utilizando quatro corretivos encontraram concentrações entre 0,61 e $107,2 \mathrm{mg} \mathrm{kg}^{-1}$, sendo o teor mais elevado referente a um calcário dolomítico.

Os níveis de $\mathrm{Cr}$ em corretivos normalmente podem ser considerados não significativos, ou seja, menores que $0,6 \mathrm{mg} \mathrm{kg}^{-1}$ (Amaral Sobrinho et al., 1992; Cravo et al., 1998). Já em fertilizantes fosfatados ou em misturas N-P-K os teores podem variar de 0,4 a $3000 \mathrm{mg} \mathrm{kg}^{-1}$ (Amaral Sobrinho et al., 1992; McGrath, 1995; Raven et al., 1997; Cravo et al., 1998; Gabe \& Rodella, 1999).

Os teores de $\mathrm{Cu}$ em corretivos e fertilizantes minerais são baixos, mas a utilização de estercos de suínos e aves juntamente com os pesticidas podem se constituir em importantes fontes deste elemento.

$\mathrm{O}$ uso de $\mathrm{CuSO}_{4}$ para melhorar a eficiência da nutrição animal, aumentar o ganho de peso e prevenir doenças em cultivos intensivos de suínos e aves (125 a $370 \mathrm{mg} \mathrm{kg}^{-1}$ na dieta) pode fazer com que os teores de Cu no esterco passem de 58 a $88 \mathrm{mg} \mathrm{kg}^{-1}$, quando nenhum suplemento é adicionado, para de 1330 a $2367 \mathrm{mg} \mathrm{kg}^{-1}$ quando Cu é adicionado (Webber, 1981; Adriano, 1986; Tiller, 1989; Baker \& Senft, 1995).

Em estudo comparativo sobre fontes de $\mathrm{Cu}$ em área de cultivo de uva (Vitis vinifera L.), Moolenaar \& Beltrami (1998) verificaram que enquanto o aporte de Cu via lodo de esgoto era de $2 \mathrm{~kg} \mathrm{ha}^{-1} \mathrm{ano}^{-1}$, o devido ao uso de fungicidas cúpricos integrados com outros pesticidas ficava na faixa de 3 a $16 \mathrm{~kg} \mathrm{ha}^{-1} \mathrm{ano}^{-1}$ (manejo convencional) e o aporte de $\mathrm{Cu}$ em propriedades de manejo orgânico variava de 15 a $49 \mathrm{~kg} \mathrm{ha}^{-1} \mathrm{ano}^{-1}$. Os teores de $\mathrm{Cu}$ em solos sob 
cultivo de uva por longos periodos podem atingir valores elevados (500 $\mathrm{mg} \mathrm{kg}^{-1}$ ) em locais em que as condições agroecológicas são mais propicias para o desenvolvimento do míldio da videira (Plasmopara viticola), com os teores de $\mathrm{Cu}_{\text {EDTA }}$ alcançando valores superiores a $100 \mathrm{mg} \mathrm{kg}^{-1}$. Estas plantações em geral não apresentam fitotoxicidade muito provavelmente devido a existência de raízes que conseguem atingir camadas mais profundas, com teores não fitotóxicos. Problemas podem ocorrer quando da renovação do cultivo (Dickinson et al., 1984; Dickinson et al., 1988; Alloway \& Ayres, 1997; Brun et al., 1998), ou quando do cultivo de plantas anuais.

Em alguns casos, a aplicação de pesticidas cúpricos foi associada a menor incidência de esquistossomose de forma que, o uso contínuo destes produtos, parece ter potencial para colocar em risco a qualidade dos aqüíferos (Dickinson et al., 1988).

Quanto ao $\mathrm{Fe}$ e ao $\mathrm{Mn}$, em corretivos e fertilizantes minerais os teores de $\mathrm{Fe}$ vão de $<10$ a $49358 \mathrm{mg} \mathrm{kg}^{-1}$ e os de $\mathrm{Mn}$ podem variar de 0,3 a $6700 \mathrm{mg} \mathrm{kg}^{-1}$ (Amaral Sobrinho et al., 1992; Raven \& Loepert, 1997; Gabe \& Rodella, 1999). Em fontes de micronutrientes Gabe \& Rodella (1999) chegaram a encontrar teores de Mn iguais a $109604 \mathrm{mg} \mathrm{kg}^{-1}$.

Os corretivos e fertilizantes minerais também podem ser fontes de Ni. Geralmente estes materiais contém de 7 a $50 \mathrm{mg} \mathrm{kg}^{-1}$ de Ni e estercos de fontes diversas podem ter a sua concentração variando de 8 a $268 \mathrm{mg} \mathrm{kg}^{-1}$ (Matthew, 1984; Kabata-Pendias \& Pendias, 1992; Raven \& Loepert, 1997). Algumas fontes de fósforo podem alcançar teores de $\mathrm{Ni}$ mais elevados como a apatita de Araxá (118 $\mathrm{mg} \mathrm{kg}^{-1}$ ), o superfosfato simples (99 a $335 \mathrm{mg} \mathrm{kg}^{-1}$ ) e o termofosfato magnesiano ( $300 \mathrm{mg} \mathrm{kg}^{-1}$ ) (Amaral Sobrinho et al., 1992; Ayuso et al.; 1996).

$\mathrm{O} \mathrm{Pb}$ pode ser adicionado aos solos agrícolas através de contaminação atmosférica; pesticidas $\left(\mathrm{PbHAsO}_{4}\right)$; impurezas em corretivos e 
fertilizantes; aplicações de estercos, resíduos urbanos e industriais (Lagerweff, 1981; Adriano, 1986).

Lagerweff (1981) sugeriu que $80 \%$ do $\mathrm{Pb}$ presente no ar fosse causado pela combustão da gasolina podendo contaminar significativamente os solos em locais de trafego intenso. A partir de meados da década de 70 a legislação de diversos países tem restringido o uso de $\mathrm{Pb}$ como aditivo na gasolina e o uso do $\mathrm{PbHAsO}_{4}$ foi substitído por outros pesticidas (Adriano, 1986; Davies, 1995).

Em corretivos o teor de $\mathrm{Pb}$ pode variar de 20 a $1250 \mathrm{mg} \mathrm{kg}^{-1}$, em fertilizantes minerais de $<0,4$ a $225 \mathrm{mg} \mathrm{kg}^{-1}$ (Kabata-Pendias \& Pendias, 1992; Raven \& Loepert, 1997). Trabalhando com fontes brasileiras Amaral Sobrinho et al., (1992) e Gabe \& Rodella (1999) encontraram para o calcário valores de $\mathrm{Pb}$ de até $27,3 \mathrm{mg} \mathrm{kg}^{-1}$; para os fertilizantes minerais valores de até $275 \mathrm{mg} \mathrm{kg}^{-1}$ e no caso específico de fontes de micronutrientes os teores de $\mathrm{Pb}$ estiveram entre 95 e $7494 \mathrm{mg} \mathrm{kg}^{-1}$.

Para o $\mathrm{Zn}$, a utilização de pesticidas como o sulfato de zinco ( $20 \%$ de $\mathrm{Zn}$ ); manconzeb ( $16 \% \mathrm{Mn}, 2 \% \mathrm{Zn}$ ) e Zineb e Ziram (1-18\% Zn), no caso de algumas culturas pode ser uma fonte importante deste elemento (Adriano, 1986). Com relação a corretivos e fertilizantes minerais, em corretivos os teores de $\mathrm{Zn}$ podem variar de 5 a $78 \mathrm{mg} \mathrm{kg}^{-1}$ e em fertilizantes fosfatados ou misturas NPK de 84 a $1070 \mathrm{mg} \mathrm{kg}^{-1}$, chegando em misturas NPK + Zn a atingir teores de $\mathrm{Zn}$ de 2220 a $5385 \mathrm{mg} \mathrm{kg}^{-1}$ (Khan et al, 1981; Amaral Sobrinho et al., 1992; Raven \& Loepert, 1997; Cravo et al., 1998; Gabe \& Rodella, 1999). O Zn pode ser usado na dieta de aves e suínos $\left( \pm 100 \mathrm{mg} \mathrm{kg}^{-1}\right.$ ) para promover 0 crescimento. A maior parte do elemento normalmente é excretada (80\%) de forma que, dependendo da dieta o esterco de animais pode conter teores de $\mathrm{Zn}$ entre 150 a $650 \mathrm{mg} \mathrm{kg}^{-1}$ (Webber, 1981; King, 1996). 
O CRSU como fonte de microelementos potencialmente tóxicos

Assim como outros insumos utilizados nos agroecossistemas, a presença de microelementos no CRSU é muito variável. Segundo Egreja Filho, (1993) eles podem depender de vários fatores, tais como grau de industrialização, época do ano, sistema de compostagem utilizado, prétratamento da matéria-prima, metodologia de análise, entre outros. Existem dois mecanismos básicos de contaminação da matéria orgânica: a contaminação direta, por adesão de partículas de pequeno diâmetro de óxidos metálicos, cinzas e limalhas a matéria orgânica úmida e a contaminação por migração de ions metálicos da fração inorgânica para a orgânica (van Roosemalen et al., 1987). A contaminação direta só é completamente evitada através da coleta e estocagem diferenciadas para a fração compostável, uma vez que a alta umidade da mesma (em torno de 65\%), impossibilita a separação de partículas finas aderidas à matéria orgânica. A separação após a fase de compostagem e maturação apresenta eficiência nula no controle da contaminação da fração orgânica por microelementos potencialmente tóxicos. (Rosseaux et al., 1992).

Diversos autores citam a necessidade da implantação de programas de coleta seletiva de resíduos sólidos urbanos. Entretanto, dependendo da forma como é realizada, geralmente preocupando-se principalmente com a separação apenas dos materiais a serem destinados à indústria, esta forma de coleta pode gerar um composto tão contaminado quanto o produzido a partir da coleta dos resíduos misturados (Marchiori, 1995).

Numa análise comparativa dos valores de Mo obtidos por Cravo et al. (1998), o composto onde se observou o maior teor do elemento foi o de Brasília, produzido a partir da coleta seletiva dos resíduos sólidos urbanos (37 mg kg ${ }^{-1}$ ). No composto de Brasília produzido a partir de coleta convencional o teor de Mo foi significativamente menor $\left(16 \mathrm{mg} \mathrm{kg}^{-1}\right)$. Uma justificativa para tal 
comportamento é a contaminação da matéria orgânica por material metálico fino, óleos, solventes, tintas, produtos farmacêuticos e cosméticos, etc. (Egreja Filho, 1993). Outra explicação plausível é a grande variabilidade dos teores de microelementos em CRSU, conforme verificado por Chitolina $\left(1998_{\mathrm{a}}\right)$, em levantamento realizado nos compostos produzidos pela usinas de compostagem da região metropolitana de São Paulo durante dezoito meses.

Normalmente os teores de microelementos em usinas de grande porte, que processam mais de $50 \mathrm{Mg}$ de resíduos urbanos por dia, por exemplo, são maiores do que os de usinas de menor porte. As usinas de maior porte, geralmente, têm catação na esteira de separação menos eficiente e quando possuem biodigestor este equipamento provoca a trituração e mistura intima dos materiais orgânico e inorgânico, aumentando os níveis de contaminação do composto (Egreja Filho, 1993; Grossi, 1993; Pressinoti \& Fernandez Jr., 1995; Abreu et al, 1996; Chitolina 1998a,; Cravo et al, 1998)

Entre os materiais presentes nos resíduos sólidos urbanos que podem contribuir para a elevação dos teores de microelementos no CRSU pode-se destacar os plásticos como a principal fonte de $\mathrm{Cd}$ (67 a 77\% do total); os metais ferrosos como fontes de $\mathrm{Cu}$ e $\mathrm{Pb}(14$ a $50 \%$ do $\mathrm{Cu}$ e 29 a $50 \%$ do $\mathrm{Pb})$; o papel como fonte de $\mathrm{Pb}(10$ a $14 \%)$; o couro como fonte de $\mathrm{Cr}(35 \%)$ e a borracha como fonte de $\mathrm{Zn}$ (32 a 37\%) (Rosseaux et al., 1989).

Avaliando-se os dados de diversos autores pode-se verificar que as concentrações de microlementos em fontes orgânicas provenientes de resíduos urbanos podem variar em função da fonte, forma de coleta, processamento e métodos de amostragem mas, normalmente, os teores no lodo de esgoto são maiores do que no CRSU, com exceção do $\mathrm{Pb}$ (El-Bassam \& Tietjen, 1977; Thompson \& Wagstaff, 1980; McGrath \& Cunliffe, 1985; Hernández et al. 1992; He et al. 1992; Egreja Filho, 1993; Grossi, 1993; Hue, 1995; Kabata-Pendias \& Adriano 1995; Stratton et al, 1995; Abreu et al, 1996; Berton, 1997; Schulz \& Römheld, 1997; Chitolina 1998 a,b. $_{\text {, }}$ (ravo et al, 1998). 
O acúmulo de microelementos potencialmente tóxicos nos solos agrícolas

Os principais motivos para a acumulação dos microelementos potencialmente tóxicos no solo são a sua baixa mobilidade (Lima et al., 1995; Collier et al, 1997; Barbarick, 1998) e a sua presença em fertilizantes minerais e orgânicos aplicados ao solo, além do uso de pesticidas, irrigação e a contaminação atmosférica em alguns casos particulares (Adriano, 1986; Kabata-Pendias, 1992; Alloway, 1995)

Mulla et al. (1980), verificaram que após 36 anos de aplicação de adubo fosfatado $71 \%$ do $\mathrm{Cd}$ acumulado permaneceu na superfície $(0-15 \mathrm{~cm}$ ) enquanto o $P$ apenas $45 \%$ o que sugere que o $\mathrm{Cd}$ seja ainda menos móvel que o fósforo, sendo que vários autores constataram sua mobilidade restrita (Williams \& David, 1973; Brams \& Anthony, 1988; Bertoncini, 1997; Martin \& Kaplan, 1998).

Em experimento com 13 anos de duração Berti \& Jacobs (1998) estudaram 0 balanço de massa do $\mathrm{Cd}$, verificando que este elemento movimentou-se apenas $10 \mathrm{~cm}$ ou menos da zona de incorporação, com pouca ou nenhuma presença abaixo de $30 \mathrm{~cm}$. A redução nos teores de $\mathrm{Cd}$ nas camadas superiores do solo, com desvios de até 100\%, foi atribuída ao movimento lateral nas parcelas causado pelo processo erosivo ou a desuniformidade dos teores no composto aplicado.

No que diz respeito a perdas por lixiviação o Cu é um dos microelementos de menor mobilidade, concentrando-se nas camadas superiores, associado a matéria orgânica, fato constatado por diversos autores (Horowitz \& Dantas, 1973; Doner, 1978; Dickinson et al., 1984; McGrath \& Lane, 1989; Cabrera et al., 1989; Baker \& Senft, 1995; Collier et al., 1997; Barbarichk, 1998; Berti \& Jacobs, 1998; Brun et al., 1998). No entanto, em alguns casos, a capacidade de adsorção do solo pode ser excedida permitindo uma maior disponibilidade e mobilidade do Cu (Lima, 1994). O aumento da concentração 
de elementos tóxicos em relação aos sítios de adsorção ou a formação de complexos podem provocar 0 incremento da mobilidade destes elementos. (Lund et al., 1976; Matthews, 1984; Lun \& Christensen, 1989; Sígolo \& Assunção, 1995; Sígolo \& Mello Jr., 1995; Amarante, 1997; Naidu et al., 1997; Mello Jr., 1998). Matthews (1984) afirma que espécies químicas catiônicas são menos móveis que formas não cationnicas, as quais incluem complexos e quelatos (polidentados) considerando, entretanto, que a mobilidade do $\mathrm{Cu}$ normalmente é baixa, embora possa ser alta sob condições ácidas. Este autor considera que ensaios em coluna ou experimentos de campos em lisímetros apresentam resultados similares. Temminghoff et al. (1997) em ensaio com colunas, usando solo arenoso, verificaram os efeitos da matéria orgânica dissolvida e do $\mathrm{pH}$ na mobilidade do $\mathrm{Cu}$. Observaram que quando $\mathrm{opH}$ era de 3,9 , cerca de $30 \%$ do Cu estava ligado à matéria orgânica dissolvida e a pH 6,6, usualmente também encontrado em solos cultivados que utilizam CRSU, mais de $99 \%$ do Cu estava ligado a matéria orgânica dissolvida, o que aumentaria a sua mobilidade e disponibilidade. McBride (1995) atribuiu o incremento nos teores de $\mathrm{Cr}$ e $\mathrm{Cu}$ abaixo de $45 \mathrm{~cm}$ de profundidade ao movimento de formas solúveis ou colóides orgânicos.

O Mo pode ser lixiviado na maioria dos solos, particularmente naqueles com valores de $\mathrm{pH}$ mais elevados e sujeitos a precipitações mais intensas, no entanto, mesmo ocorrendo na forma aniônica, tende a acumular-se na camada superficial devido a associação com a matéria orgânica do solo ou presença de argila consolidada (Thornton, 1981; Adriano, 1986; Barbarick et al. (1998).

Haan (1981), através de aplicações de $20 \mathrm{Mg} \mathrm{ha}^{-1}$ de CRSU em solos argilosos e arenosos, de 1948 a 1971, observou, em média, os seguintes maiores incrementos de microlementos no solo: $\mathrm{Zn}, 4,5$ vezes; $\mathrm{Hg}, 4,2$ vezes; $\mathrm{Pb}, 4,0$ vezes e Mo 3,7 vezes. 
Nos trabalhos sobre aplicação de CRSU por longos períodos realizados no Brasil, Lima et al. (1995) e Collier et al. (1997) observaram que o elemento que verificou maior incremento devido a aplicação de CRSU foi o $\mathrm{Cu}$. No glei pouco húmico com 11 anos de aplicação houve um incremento de 10 vezes no teor das áreas tratadas em relação às áreas tomadas como referência (de 3,1 para $34,9 \mathrm{mg} \mathrm{kg}^{-1}$ ) (Collier et al., 1997). No podzólico vermelho-amarelo Lima et al. (1995) observou um incremento de 4 vezes na área com 4 anos de aplicação de CRSU (de 13,8 para $53,2 \mathrm{mg} \cdot \mathrm{kg}^{-1}$ ) e de cerca de 30 vezes para a área com 16 anos de aplicação de CRSU (de 1,7 para $48 \mathrm{mg} \mathrm{kg}^{-1}$ ).

No glei pouco húmico avaliado por Collier et al. (1997), também pode-se observar um aumento significativo nos teores de $\mathrm{Zn}$ das áreas tratadas com CRSU (de 23 para $47 \mathrm{mg} \mathrm{kg}^{-1}$ ) mas no podzólico vermelho-amarelo avaliado por Lima et al. (1995), o Zn apresentou problemas de determinação analítica.

Biodisponibilidade de microelementos potencialmente tóxicos

Com relação a biodisponibilidade de microelementos potencialmente tóxicos o CRSU pode ser considerado como fonte ou como dreno destes elementos.

o DTPA é extrator mais utilizado para prever a biodisponibilidade de microelementos, provavelmente por ser considerado o mais sensivel às mudanças nas condições de solo (Coker \& Matthews, 1983). Segundo Beckett (1989), em extensa revisão sobre extratores para microelementos em solos e biossólidos, os teores obtidos em DTPA e EDTA podem ser correlacionados, sendo os valores obtidos em DTPA ligeiramente superiores. 
O aspecto principal da química dos microelementos potencialmente tóxicos no solo está relacionado à formação de complexos com a matéria orgânica. Enquanto cátions monovalentes (como $\mathrm{Na}^{+}$e $\mathrm{K}^{+}$) se ligam a matéria orgânica por adsorsão eletrostática, cátions polivalentes de alguns microelementos potencialmente tóxicos têm a capacidade de formar ligações coordenadas com moléculas orgânicas. Os componentes orgânicos do solo podem formar complexos solúveis ou insolúveis com estes elementos. Os agentes quelantes do solo dividem-se em duas classes: os bioquímicos, dos quais fazem parte ácidos orgânicos, aminoácidos, açúcares, compostos derivados de liquens e outros organismos; e os quelantes húmicos, representados pelos ácidos húmicos e fúlvicos. Sob certas circunstâncias, a concentração de um íon metálico pode ser reduzida em niveis não tóxicos por complexação. Isto é particularmente verdade quando o complexo formado apresenta baixa solubilidade (caso dos ácidos húmicos e outros ligantes de alto peso molecular) (Stevenson, 1982).

A aplicação de matéria orgânica humificada pode ser uma opção para minimizar a toxicidade causada por microelementos potencialmente tóxicos e pesticidas. Stevenson (1982) associa a imobilização de tais elementos tóxicos principalmente ao elevado poder complexante do húmus. Além da redução da atividade dos elementos tóxicos, a ação do húmus evita que estes sejam lixiviados para cursos d'água ou águas subterrâneas.

Em geral, a biodisponibilidade dos microelementos potencialmente tóxicos diminui com o aumento do teor de carbono orgânico do solo, com exceção do zinco, em alguns casos (Lake, 1987b). Segundo Petruzzelli \& Lubrano (1986), citados por Egreja Filho (193), com o passar do tempo, com a decomposição dos colóides orgânicos do solo espera-se que o efeito protetor da matéria orgânica desapareça. Entretanto, Lake (1987b), afirma que o efeito da matéria orgânica na imobilização dos metais é notado apenas com o decorrer do tempo. Este autor relata que a 
absorção de cádmio, aplicado como lodo de esgoto imediatamente antes do plantio, é no mínimo 10 vezes maior do que quando o plantio se efetua em solos tratados durante vários anos consecutivos com o lodo.

A aplicação de CRSU pode afetar diretamente a disponibilidade dos microelementos. Nas primeiras décadas deste século, na Holanda, o composto era utilizado em locais úmidos para combater doenças de plantas, que mais tarde foram atribuídas a deficiências de $\mathrm{Cu}$ (Haan, 1981). Roston \& Kimoto (1987) também observaram na cultura da alface cultivada em solo glei respostas altamente positivas à aplicação de Cu. Purves \& Mackenzie (1973) verificaram que a adição de CRSU na base de $100 \mathrm{Mg} \mathrm{ha}^{-1} \mathrm{em}$ alguns casos alterou significativamente os teores de CUEDTA (de 3,3 para $13,9 \mathrm{mg} \mathrm{kg}^{-1}$ ) e em outros não (de 6,7 para $6,9 \mathrm{mg} \mathrm{kg}^{-1}$ ).

A matéria orgânica do solo tem sido associada a um incremento na biodisponibilidade do $\mathrm{Mn}$, pelo seu papel como fonte de elétrons para reações redutoras, por servir de substrato para microrganismos, por participar de reações de adsorção, além de compostos orgânicos provenientes de exsudatos radiculares (Reisenauer, 1988).

O comportamento dos microelementos no sistema solo-planta, além da matéria orgânica pode ser afetado por outros atributos do solo como o $\mathrm{pH}$, a CTC, presença de óxidos e interações entre os microelementos.

De maneira geral a solubilidade dos metais diminui com 0 aumento do $\mathrm{pH}_{1}$ exceto para o molibdênio, que costuma ocorrer na forma aniônica. Lindsay \& Norwell (1978) observaram que um decréscimo de uma unidade de $\mathrm{pH}$ provoca um aumento da concentração do $\mathrm{Zn}$ em 100 vezes. Lake (1987b) verificou aumento nas concentraçöes de Cd, Co, Mn e Zn da solução dos solos agricultáveis proporcional ao decréscimo do $\mathrm{pH}$, enquanto que os teores de Cu se mantiveram inalterados.

Deficiência severa de $\mathrm{Zn}$ normalmente ocorre associada com $\mathrm{pH}$ do solo elevado. Prótons competem com o $\mathrm{Zn}$ pelos pontos de adsorção, 
além de afetar a precipitação e óxidos de $\mathrm{Fe}$ e $\mathrm{Al}$, fazendo com que normalmente o $\mathrm{pH}$ seja a variável do solo mais determinante no que diz respeito a fitotoxicidade deste elemento, mesmo para teores elevados de $\mathrm{Zn}$ (3030 mg kg ${ }^{-1}$ ) (Matthews, 1984; Albasel \& Cottenie, 1985; Adriano, 1986; Chaney, 1994).

Lagerwerff et al. (1977) consideram que alguns metais são mais influenciados pelo $\mathrm{pH}$ do que outros, estabelecendo a seguinte ordem: $\mathrm{Zn}>\mathrm{Cd}>\mathrm{Pb}>\mathrm{Cu}$. A liberação dos metais contidos em biossólidos, segundo Adams \& Sanders (1984), ocorre em diferentes valores limite de $\mathrm{pH}: 4,5$ para - $\mathrm{Cu} ; 5,8$ para o Zn e 6,3 para o $\mathrm{Ni}$.

Quanto a CTC, Lake (1987b) considerou que este atributo é um dos mais importantes indicadores da capacidade de retenção de microelementos potencialmente tóxicos na fase sólida do solo. Em geral, solos com valores de CTC mais elevados suportam maiores quantidades de metais do que os de baixa capacidade de troca. Por outro lado, Petruzzelli \& Lubrano (1986), citados por Egreja Filho (193), ponderaram que os fenômenos predominantemente eletrostáticos que governam a CTC, constituem-se num dos efeitos atenuantes mais fracos no sentido de manter o metal adsorvido à fase sólida do solo, considerando que os metais na forma trocável são prontamente disponiveis às plantas, superada apenas pelas formas solúveis.

Os óxidos de $\mathrm{Mn}$ interagem com as formas biodisponíveis, servindo tanto como fonte quanto como dreno. Além dos fatores edafoclimáticos, a capacidade genotípica da biota parece exercer grande influência atividade de absorção deste elemento (Reisenauer, 1988). A química e bioquímica do Mn no solo é bastante complexa, pelas seguintes razões: pode existir em diversos estados de oxidação; forma óxidos não estequiométricos em estados de oxidação mistos, os óxidos ocorrem em estados cristalinos e pseudocristalinos, seus óxidos formam coprecipitados e provavelmente superestruturas com óxidos de ferro; óxidos e hidróxidos de $\mathrm{Fe}$ e $\mathrm{Mn}$ exibem 
propriedades anfotérica, interagindo tanto com ânions quanto com cátions; processos de oxidação e redução são influenciados por fatores químicos e microbiológicos (Adriano, 1986).

Em condições de campo, a toxicidade de Mn normalmente ocorre em condições ácidas, associadas a toxicidade do $\mathrm{Al}$, ou em ambiente redutor. Em casos severos, altos teores de Mn podem reduzir a absorção de $\mathrm{Fe}$ e induzir sua deficiência (Hannam \& Ohki, 1988).

A importância da biodisponibilidade adequada de Mn pode ser ressaltada pela forte correlação entre teores do elemento nos tecidos das plantas e incidência de doenças. Os mecanismos de controle podem estar associados a ação direta sobre o patógeno (inibição de processos enzimáticos) ou sobre o hospedeiro (síntese de compostos fenólicos inibidores e lignina) (Chaboussou, 1987; Huber \& Wilhelm, 1988).

Face ao menor potencial de risco do Mn para o ambiente e para a cadeia trófica quando comparado com outros metais (Chaney 1983, citado por Adriano, 1986), muitas vezes os estudos envolvendo resíduos não abrangem este elemento. Entretanto, as interaçōes do $\mathrm{Fe}$ e $\mathrm{Mn}$ com outros elementos potencialmente tóxicos, como o $\mathrm{Cd}, \mathrm{Cu}$ e $\mathrm{Zn}$ é um importante fator que propicia a verificação do efeito platô ${ }^{11}$ quando da aplicação de biossólidos e CRSU (Chaney, 1993; Chaney \& Ryan, 1993; Chaney et al., 1994).

$\mathrm{O}$ antagonismo entre o $\mathrm{Fe}$ e outros elementos ( $\mathrm{Cd}, \mathrm{Mn}, \mathrm{Ni})$ tem sido observado em diversas culturas onde o excesso de metais provocou uma deficiência induzida de Fe e o aparecimento de clorose (redução na absorção e translocamento do Fe resultando em decréscimo na clorofila). Por outro lado, a presença de compostos de $\mathrm{Fe}$ no solo pode reduzir a absorção de outros elementos. A proporção dos elementos no solo e nos tecidos das plantas parece ser mais importante para o metabolismo destas do que as

\footnotetext{
${ }^{1}$ Efeito platô: limitação do teor dos micronutrientes nas plantas a um determinado patamar, a despeito do aumento de sua concentração no solo (Chaney, $1990_{a}, b$; Chaney et al., 1998)
} 
concentrações propriamente ditas (Adriano, 1986; Kabata-Pendias \& Pendias, 1992).

Concentrações excessivas de metais produzem cloroses associadas a deficiência de $\mathrm{Fe}$, com sintomas secundários específicos do metal em questão, e, em sendo o $\mathrm{Ni}$, estes sintomas são mais pronunciados do que no caso de outros metais. O Ni é considerado siderófilo e a diminuição da relação Ni:Fe no solo diminui riscos de fitotoxicidade deste microelemento (Adriano, 1986; Kabata-Pendias \& Pendias, 1992).

Comparando os efeitos da adição de CRSU nos teores totais e biodisponiveis de microelementos Cabrera et al. (1992) verificaram os seguintes incrementos relativos: com relação aos teores totais $-\mathrm{Zn}, 36 \% ; \mathrm{Cu}, 20 \% ; \mathrm{Pb}$, $15 \%$; Mn, $5 \%$; Cd, $4,9 \%$; $\mathrm{Ni}, 3,1 \%$; $\mathrm{Cr}, 2,8 \%$ e para os teores disponiveis $\mathrm{Zn}, 230 \%$; $\mathrm{Cr}, 62 \%$; Fe, $41 \%$; $\mathrm{Cu}, 22 \%$; Cd, $17 \%, \mathrm{~Pb}, 13 \%$ e $\mathrm{Mn}$ e Ni, $11 \%$.

Os teores de $\mathrm{Zn}$ disponível são positivamente correlacionados com os teores totais, com a matéria orgânica, com o teor de argila e a CTC e inversamente correlacionados com o pH e com a saturação de bases (Adriano, 1986). Castro et al., (1992) verificaram uma diminuição dos teores de $\mathrm{Zn}$ ao longo do perfil, o que foi atribuído a redução nos teores de matéria orgânica. Entretanto, a disponibilidade do $\mathrm{Zn}$ normalmente é baixa em solos orgânicos. Condições redutoras reduzem a disponibilidade do $\mathrm{Zn}$, devido a formação de precipitados insolúveis, sendo que, nestas condições, a matéria orgânica pode ser considerada mais importante do que os óxidos de Fe e Mn para moderar a presença de teores no solo potencialmente fitotóxicos (Adriano, 1986).

A disponibilidade de $\mathrm{Zn}$ no solo parece depender de mecanismos bastante complexos, com a participação do $\mathrm{pH}$ e dos óxidos de $\mathrm{Fe}$, Al e Mn (McBride \& Blasiak, 1979). Kuo et al. (1985) afirmam que embora a disponibilidade do $\mathrm{Zn}$ seja marcadamente influenciada pelo $\mathrm{pH}$, freqüentemente este parâmetro é menos determinante do que o teor de óxidos de $\mathrm{Fe}$ amorfos. 
Para estes autores o teor de matéria orgânica teria pouca influência na biodisponibilidade do Zn para espécies acumuladoras como beterraba e alface.

\subsection{Extração seqüencial de microelementos}

Quanto a distribuição de espécies químicas metálicas em fertilizantes orgânicos e minerais, a maioria dos trabalhos relacionando microelementos potencialmente tóxicos com matrizes orgânicas, tem se limitado a uma avaliação dos teores totais destes metais, o que não dá idéia da sua mobilidade e disponibilidade no ambiente. Deve-se, entretanto, lembrar que uma vez incorporado o composto ao solo, novos equilíbrios se estabelecem, provocando mudanças nas formas químicas dos metais (Chang et al., 1984).

O uso do teor total de um determinado elemento no solo como critério para estabelecer uma possível contaminação sugere que todas as suas formas químicas causariam o mesmo efeito no ambiente. Todavia, deve-se levar em conta que, cada elemento pode encontrar-se em diferentes formas químicas na solução do solo ou associado a diferentes compartimentos do mesmo. Uma boa ilustração deste fato é a ocorrência comum de deficiências de Fe e Mn em plantas, a despeito de altos teores destes elementos na maioria dos solos cultivados (McBride, 1989).

Além da diversidade genotípica dos organismos que ocorrem em um agroecossistema, diversos atributos do solo podem implicar em diferentes graus de biodisponibilidade, tais como: tipo e quantidade de colóides (minerais de argila, óxidos, matéria orgânica), concentração do elemento e da solução iônica, CTC; pH, pe, presença de elementos competidores ou ligantes orgânicos e inorgânicos, manejo (irrigação, intensidade do cultivo, variedade cultivada, presença de invasoras etc.) (Shuman, 1975, Shuman, 1976, Shuman, 1977; Sims \& Patrick Jr., 1978; Kuo \& Baker, 1980; Shuman, 1982; Soon \& Bates, 1982; Shuman \& Hargrove, 1985; Shuman, 1986; Sims, 1986; Shuman, 
1988; Keller \& Védy, 1994; Ross, 1994a, Mandal \& Hazra, 1997; Shuman \& Wang, 1997; Jones, 1998).

O uso de extratores químicos para correlacionar a concentração de microelementos no solo com a absorção destes pelas plantas em condições anormais (deficiência ou toxicidade), têm apresentado mais sucesso para as situações de deficiência (Ross \& Kaye, 1994). Uma das razões para que isso ocorra seria a melhor operacionalidade da condução de experimentos de campo para condições de deficiência do que para situações de toxicidade.

Um aspecto que dificulta o poder de previsão da química para situações de excesso de concentração se deve ao fato de que, para análise de risco de toxicidade, as interações entre os atributos do solo e o comportamento dos microelementos ao longo do tempo assumem maior importância.

Uma forma de melhor compreender estes processos é a utilização da extração seqüencial, em que se usam diferentes reagentes com a intenção de solubilizar, de forma seletiva, as diversas formas dos elementos ligados aos componentes do solo de diferentes maneiras, partindo-se de extratores menos agressivos para os adsorvidos fisicamente e fracamente ligados, para a utilização de extratores progressivamente mais destrutivos, visando a solubilização de formas fixadas com energia mais elevada, por vezes até compondo a estrutura dos minerais (Beckett, 1989; Camargo et al., 1999). Diversos fatores podem afetar a quantidade observada em cada fração: i) tempo de contato entre o solo e o extrator; ii) peso da amostra, volume do extrato e relação solo:solução extratora; iii) grau de agitação da extração; iv) temperatura da extração. Entre os principais problemas enfrentados para o emprego da extração seqüencial tem-se a eficiência do extrator e sua seletividade, o que implicou no desenvolvimento de inúmeras técnicas de extração (geralmente utilizando-se de três a oito extratores em seqüência), o que torna extremamente difícil a comparação entre diferentes estudos (Le Riche \& Weir, 1963; Tessier et al., 1979; Schalscha et al., 1980; Sposito et al., 1982; 
Beckett, 1989; McBride, 1989; Warden \& Reisenauer, 1991; He \& Singh, 1993; Salomons, 1993; Ross, 1994a, Gomes, 1996; Gomes et al., 1997; Ma \& Rao, 1997).

O termo especiação química normalmente é mais utilizado para as diversas formas de um determinado elemento que ocorrem na solução do solo. Programas para mensurar a especiação iônica têm sido desenvolvidos visando avaliar a fitodisponibilidade destas diferentes formas (Holm et al., 1995; Berton, 1999). Um aspecto importante a ser considerado são as diferenças encontradas entre 0 ambiente rizosférico e não rizosférico para as diversas espécies presentes no agroecossistema (cultivadas e espontâneas/invasoras) (Luo \& Christie, 1997; Jones, 1998). Já o fracionamento das diversas formas químicas dos microelementos pode ser definido basicamente sob dois aspectos: 1) funcionalmente, por exemplo, fração trocável ou fração ligada aos óxidos de Fe e Mn (que pode ser ainda subdividida em ligação elemento-óxido facilmente redutível, ligação elemento-óxido amorfo e ligação elemento-óxido cristalino) e 2) operacionalmente, definida pelos procedimentos ou reagentes utilizados para obter os extratos, por exemplo, fração extraível em $\mathrm{MgCl}_{2} 1 \mathrm{~mol} \mathrm{~L}^{-1}$ a $\mathrm{pH} 7$ (trocável), ou extraivel em $\mathrm{NH}_{2} \mathrm{OH} . \mathrm{HCl} 0,04 \mathrm{~mol} \mathrm{~L}^{-1}$ em solução de $\mathrm{CH}_{3} \mathrm{COOH}$ a $25 \%(\mathrm{v} / \mathrm{v})$, a $96^{\circ} \mathrm{C} \pm 3^{\circ} \mathrm{C}$ (para microelementos ligados a óxidos de ferro e manganês) (Lake et al., 1984; Ure et al., 1993, Ure, 1995).

A definição operacional possui a vantagem de melhor exprimir as limitações do poder de previsão da extração analítica. Tomando por base a complexidade da atuação de ácidos orgânicos presentes nos exsudatos radiculares, incluindo aquisição de nutrientes, detoxicação de metais, intemperismo de minerais e atração de patógenos (Jones, 1998), no caso de análises laboratoriais de rotina para fins avaliação da fertilidade de solos agrícolas, parece mais plausível a utilização da definição operacional, por exemplo "extraivel em DTPA", do que a definição funcional, "teor biodisponivel". No entanto, no caso da extração seqüencial, a intensidade 
e seletividade da extração dependem da ordem em que são utilizados os reagentes e a sua interação com os diferentes componentes, que podem estar presentes no solo em diferentes proporções (Miller et al., 1986 ${ }_{\mathrm{a}}$ ). Deste modo, a definição operacional para a extração seqüencial, vista de forma isolada, também apresenta limitações.

Em diferentes situações pode ocorrer a dissolução de compostos químicos não similares por um determinado reagente ou ainda, o reagente utilizado pode não ser eficiente para solubilizar totalmente compostos químicos similares (Beckett, 1989). Apesar das perspectivas de evolução dos métodos instrumentais de análise, é conveniente ter-se em mente que, as dificuldades analíticas dos métodos de extração seqüencial podem ser um reflexo da complexidade inerente do sistema solo.

O procedimento analítico para extração seqüencial desenvolvido por Tessier et al. (1979) para sedimentos fluviais vem sendo o método de fracionamento mais amplamente utilizado. Estes autores procuraram associar a definição funcional e a operacional, através do acompanhamento das alterações dos resíduos após cada extração com análises de raios-X.

\subsubsection{Microelementos potencialmente tóxicos nas plantas}

\subsubsection{Absorção e transporte de microelementos em plantas}

A capacidade de formar complexos bastante estáveis, que geralmente é a responsável pela alta toxicidade de alguns microelementos, tornando possivel a alteração de algumas funções metabólicas normais nos seres vivos, pode também reduzir a absorção destes pelas plantas, pois as reações com os minerais e com matéria orgânica do solo prevalecem (Haynes \& Traina, 1998, citados por Guilherme, 1999).

A determinação do teor limite de um microelemento no solo depende de sua mobilidade através das diversas rotas de exposição até 0 
ponto final ou alvo (seres humanos, animais, plantas, biota do solo, predadores), no caso da legislação americana (EPA, 1995; Chaney et al., 1998). A legislação dos países europeus normalmente leva em conta como rota de exposição a cadeia alimentar, onde plantas são diretamente consumidas ou servem de alimento para animais, cujos produtos são consumidos pelo ser humano (Kabata-Pendias \& Pendias, 1992; Alloway, 1995).

Em função da baixa taxa de absorção do $\mathrm{Pb}$, o teor permitido para este elemento no solo é bem maior do que o permitido para o Cd, embora o Pb seja mais tóxico que o Cd (Kabata-Pendias \& Pendias, 1992; Pierzynski et al., 1994).

Todas as plantas respondem a aumentos na concentração de microelementos potencialmente tóxicos em seu ambiente imediato. A natureza destas respostas dependerá da sensibilidade individual, da intensidade (concentração e duração) da exposição, do metal, propriamente dito, e da forma em que se encontra (Baker \& Walker, 1989)

Haan (1981) através de aplicações de $20 \mathrm{Mg} \mathrm{ha}^{-1} \mathrm{ano}^{-1}$ de CRSU de 1948 a 1971 em solos observou, em média, os maiores incrementos de metais no solo eram: $\mathrm{Zn}, 4,5$ vezes; $\mathrm{Hg}, 4,2$ vezes; $\mathrm{Pb}, 4,0$ vezes e Mo 3,7 vezes. No entanto, o maior incremento nas plantas cultivadas foi do Mo (1,8 vezes), sendo do $\mathrm{Zn}(1,4$ vezes) o segundo maior incremento. Estes valores observados por Haan (1981) em área de aplicação de CRSU alertam para o potencial do Mo para causar desbalanços nutricionais nas plantas, talvez pelo fato da elevação do $\mathrm{pH}$ nos solos cultivados

Embora o Mo seja considerado pouco tóxico para a espécie humana seu potencial fito e zootóxico deve ser ponderado. No caso das plantas o excesso de Mo pode prejudicar o metabolismo do Fe e para animais, notadamente os ruminantes, teores elevados de Mo na alimentação podem provocar deficiência induzida de Cu (molibdenose) (Adriano, 1986). O risco de molibdenose pode ser maior em solos arenosos, pobres em $\mathrm{Cu}$, ou em solos 
com altos teores de matéria orgânica, pela ação da matéria orgânica indisponibilizando o Cu para as plantas (Kubota \& Allaway, 1973).

Embora algumas plantas possam acumular altos teores de Mo, devido a capacidade genotípica da planta e solubilidade do elemento no solo, sintomas de fitotoxicidade em condições de campo são raros. O molibdênio normalmente se encontra associado a hidróxidos de $\mathrm{Fe}$ e óxidos de $\mathrm{Al}$ e com substâncias orgânicas, tendo interações antagônicas com o $\mathrm{Cu}, \mathrm{Mn}$ e $\mathrm{Fe}$ O mais comum é a ocorrência de deficiência de Mo, principalmente em solos ácidos, ricos em ferro e quando a planta cultivada é uma leguminosa (KabataPendias \& Pendias, 1992; Edwards et al., 1995).

Dos metais presentes no CRSU o $\mathrm{Cu}$, ○ $\mathrm{Ni}$ e $\circ \mathrm{Zn}$ são considerados os que mais comumente provocam fitotoxicidade, enquanto que $\mathrm{Cd}, \mathrm{Cr}, \mathrm{Hg}, \mathrm{Mn}$ e $\mathrm{Pb}$ têm menor potencial para causar problemas neste aspecto. (Coker \& Matthews, 1983; Matthews, 1984; Adriano, 1986; Kabata-Pendias \& Pendias, 1992; Alloway, 1995; Werner \& Warnusz, 1997; Barbarick et al.; 1998; Berti \& Jacobs, 1998).

As concentrações fitotóxicas de $\mathrm{Cu}, \mathrm{Ni}$, e $\mathrm{Zn}$ ocorrem abaixo dos teores considerados de risco para seres humanos e animais, o que constitui um mecanismo que estabelece uma barreira para a entrada destes elementos na cadeia trófica (Tiller, 1989; Chaney, 1993a,b).

$$
\text { Interações sinérgicas entre microelementos que }
$$
incrementassem a absorção destes pelas plantas geralmente não são observadas em condições de campo. Comportamentos desta natureza, algumas vezes observados para experimentos realizados em vasos, podem ser resultado da destruição de barreiras fisiológicas provocadas pela concentração excessiva destes elementos (Kabata-Pendias \& Pendias, 1992). Outros fatores que podem interferir são a temperatura e umidade do ar e do solo (De Vries \& Tiller, 1978), além da ação de ions osmoreguladores $\left(\mathrm{Na}^{+}, \mathrm{K}^{+}\right)$provocando uma maior absorção de microelementos em condições de vaso ou ainda de casa de 
vegetação. (Costa, 1994; Costa et al., 1994a,b; Peverly \& Gates, 1994; Santos, 1995).

Com relação a passagem de elementos tóxicos presentes no solo para niveis tróficos mais elevados as plantas podem funcionar como um mecanismo que favorece ou que limita esta transferência. Estes mecanismos dependem da absorção do elemento pela planta, de sua mobilidade dentro da mesma e de qual é a parte comestível da planta.

O transporte a longa distância em microelementos em plantas superiores depende dos tecidos vasculares (xilema e floema) e está particularmente relacionado com a intensidade da transpiração. $O$ modelo de distribuição e acumulação dos microelementos é muito variável, dependendo do elemento considerado, da espécie de planta e da estação de crescimento da mesma. O comportamento mais comum é a predominância dos microelementos nas raízes (Kabata-Pendias \& Pendias, 1992; King, 1996).

Chaney \& Oliver (1996) dividiram os elementos em grupos: Grupo 1 , elementos que são tão insolúveis no solo que são muito pouco transferidos mesmo quando o solo possui teores elevados (ex. $\mathrm{Cr}$ ); Grupo 2, elementos que podem ser absorvidos pelas raizes mas não são translocados para a parte aérea em quantidades que representem risco (ex. Pb); Grupo 3, elementos que são absorvidos e translocados, mas os teores fitotóxicos são inferiores aos zootóxicos (ex. B, Cu, Ni, Mn, $\mathrm{Zn}$ ) e Grupo 4, elementos cujos teores zootóxicos são inferiores aos que provocam fitotoxicidade (ex. Cd e Mo).

\subsubsection{Riscos toxicológicos para a alimentação humana}

Bioacumulação e biomagnificação

Robards \& Worsfold (1991) diferenciam bioacumulação e biomagnificação. Biomagnificação diz respeito a transferência de contaminantes 
entre níveis tróficos via ingestão enquanto que bioacumulação requer absorção direta independente de cada nível trófico. A bioacumulação depende de dois processos competitivos: absorção e depuração e é relacionada com o nível de contaminação do ambiente e dos fatores que interferem nestes dois processos.

Martin \& Coughtrey (1981) afirmam que embora hajam evidências de acumulação biológica de microelementos em plantas, herbívoros e animais detritivoros o grau em que isto ocorre é dependente do elemento considerado. O conceito de biomagnificação é proveniente do fato de que contaminantes lipofílicos, como é o caso de organoclorados (ex: o DDT), são efetivamente absorvidos e retidos nos tecidos animais, acumulando-se através dos diversos niveis tróficos (Laskowski, 1991). No caso dos metais, o metil-Hg é o único caso de biomagnificação já verificado em cadeias alimentares. No entanto, diferentemente do que ocorre nos ambientes aquáticos, no caso dos ambientes terrestres a transferência do $\mathrm{Hg}$ parece não oferecer risco para os seres humanos. Outros metais que ocorrem em baixas concentrações como $\circ \mathrm{Cd}$, ० As e $\circ \mathrm{Pb}$ podem ser biominimizados ao longo dos diferentes niveis tróficos pois, menos de $1 \%$ do total absorvido é retido no corpo dos animais (Beyer ${ }^{2}, 1986$, citado por Chaney et al., 1998a).

Toxicologia dos microelementos para seres humanos

Em lugar do conceito de "dose diária aceitável" usado para aditivos e pesticidas, no caso dos microelementos potencialmente tóxicos a comissão do CODEX alimentarius (FAO/WHO) para aditivos e contaminantes tem utilizado o conceito de "ingestão semanal tolerável provisória". Esta diferenciação no periodo considera que os microelementos têm caráter acumulativo. A indicação "tolerável" em substituição ao termo "aceitável" indica

\footnotetext{
2 BEYER, W.N. A re-examination of biomagnification of metals in terrestrial food chains. Environ.

Toxicol. Chem. v. 5, p. 863-864. 1986.
} 
uma maior preocupação no caso dos microelementos potencialmente tóxicos $e$ é mais restritiva do que para pesticidas. A avaliação provisória indica a incerteza sobre a ingestão calculada e o grau de susceptibilidade individual (CODEX, 1998; CODEX 1999a,b,c).

Considera-se que em humanos adultos a maior parte do $\mathrm{Pb}$ ingerido por via oral é eliminado pelas fezes, sendo que apenas cerca de $10 \%$ deste elemento é absorvido. Deste percentual, aproximadamente $76 \%$ é eliminado na urina e o restante através de estruturas epiteliais. Para indivíduos jovens, de metabolismo mais intenso, a absorção via oral pode chegar a valores da ordem de $50 \%$ da quantidade do elemento ingerido (Albert, 1985). Os cálculos dos valores admissíveis nos alimentos são provisórios, existindo muita controvérsia sobre os níveis toleráveis de $\mathrm{Pb}$ no organismos humano. A forma química do elemento utilizada e sua biodisponibilidade têm grande importância para a avaliação da toxicidade. Administrando $\mathrm{Pb}$ a ratos Freeman et al. (1992) verificaram que o acetato de $\mathrm{Pb}$ se mostrava significativamente mais biodisponível do que concentrações equivalente de $\mathrm{Pb}$ fornecidas através de solo contaminado de áreas de mineração. Enquanto que no caso do acetato de $\mathrm{Pb}$ o fígado dos animais apresentava concentrações que aumentavam linearmente com as aplicações do elemento, chegando a quase $2 \mathrm{mg} \mathrm{kg}^{-1}$, para a utilização do solo contaminado os teores no fígado dos ratos mantiveram-se num patamar inferior a $0,2 \mathrm{mg} \mathrm{kg}^{-1}$. Este efeito também ocorreu para os teores verificados no sangue e nos ossos. Este resultado tem grande importância uma vez que a concentração de $\mathrm{Pb}$ em biossólidos é limitada pelos efeitos que a ingestão direta possa causar em crianças (Chaney \& Ryan, 1993).

Harrison (1993) apresentam estudo realizado na Inglaterra que apontou que o pão e os cereais, juntamente com as bebidas em geral são os dois principais componentes da dieta que contribuem para a ingestão de $\mathrm{Pb}$ pela população (cerca de $20 \%$ cada um). Os vegetais verdes, vegetais enlatados e outros vegetais contribuiam com pouco mais de $5 \%$ cada um e a 
batata com cerca de $3 \%$. Dentro da metodologia de cálculo de exposição da população a um determinado contaminante a definição do tipo de dieta assume grande importância. Segundo o CODEX $\left(1999_{\mathrm{b}}\right)$ o Brasil é classificado como grupo $\mathrm{K}$, onde os cereais participam com $19,1 \%$ da ingestão de $\mathrm{Pb}$, as raizes e tubérculos com $18,7 \%$ e os vegetais participam com apenas $3,7 \%$.

Um aspecto importante a ser considerado é a identificação das fontes de contaminação dos alimentos com o Pb.

O processamento e embalagem podem incrementar significativamente os teores de $\mathrm{Pb}$ de gêneros alimentícios, como por exemplo $\mathrm{O}$ arroz $\left(7,49 \mathrm{mg} \mathrm{kg}^{-1}\right)$ e o trigo $\left(1,39 \mathrm{mg} \mathrm{kg}^{-1}\right)$. Em alimentos enlatados, em média $30 \%$ da contaminação de $\mathrm{Pb}$ é proveniente do processamento. (Braude et al., 1980; Concon, 1988; WHO, 1996).

Prado Filho \& Cantarelli (1984) avaliando enlatados de extrato de tomate comercializados em Piracicaba (SP) verificaram teores de chumbo entre 0,10 e $34,60 \mathrm{mg} \mathrm{kg}^{-1}$. A proibição pela legislação brasileira do uso da solda de $\mathrm{Pb}$ e $\mathrm{Sn}$ em embalagens de gêneros alimentícios (BRASIL, 1999) deverá contribuir para reduzir a presença de $\mathrm{Pb}$ nos alimentos.

Segundo Chaney \& Ryan (1993) a redução do $\mathrm{Pb}$ nas emissões atmosféricas e no processamento e embalagem dos alimentos podem decrescer significativamente o conteúdo de $\mathrm{Pb}$ nos alimentos. Estes autores citam que Bolger et al. (1991) ${ }^{1}$ verificaram que os teores do elemento no sangue de crianças decresceu de 20 a $25 \mu \mathrm{g} \mathrm{dL}^{-1}$ em 1970 para 3 a $4 \mu \mathrm{g} \mathrm{dL}^{-1} \mathrm{em} 1990$.

\footnotetext{
${ }^{1}$ BOLGER, K.W.; JONES, J.W.; LINSCOT, D.; WRIGHT, S.K.; STROUBE, W; CUNNINGHAM, W. Reductions in dietary lead exposure in the United States. Chem. Spec. Biovail. v. 3, p. 31-36. 1991.
} 


\section{MATERIAL E MÉTODOS}

\subsection{Solos}

\subsubsection{Escolha e localização dos solos}

Com o auxilio da Coordenadoria de Assistência Técnica Integral - CATI e da ENTERPA (empresa gerenciadora das usinas de reciclagem da região metropolitana de São Paulo) pode-se determinar as principais regiões consumidoras de composto de resíduos sólidos urbanos (CRSU) e verificar que um dos principais cultivos de hortaliças em que o mesmo é utilizado é a alface (Lactuca sativa L.).

Os solos podzólicos representam uma fração significativa das áreas agrícolas próximas à região metropolitana de São Paulo, enquanto que é nos solos glei que se concentra a produção de hortaliças.

Assim, foram identificadas duas áreas agrícolas nas quais o composto tem sido aplicado e cujos solos apresentam características distintas: Área $\mathrm{A}$ : um solo glei húmico álico, $\mathrm{A}$ proeminente, situada no município de Biritiba Mirim - SP (23 ${ }^{\circ} 02^{\prime} S$ e $\left.46^{\circ} 03 W G\right)$, onde foram escolhidas três propriedades agrícolas, uma com uso de corretivos e fertilizantes minerais e, aproximadamente, 12 anos de aplicação de CRSU (utilizou de 1982 a 1989 e de 1994 a 1997 - propriedade 1), e outras duas (propriedades 2 e 3), com uso de corretivos e fertilizantes minerais e orgânicos, mas onde nunca foi aplicado 0 CRSU; Área B: um solo podzólico vermelho-amarelo distrófico, A moderado, situada no município de Suzano ( $23^{\circ} 03^{\prime} \mathrm{S}$ e $46^{\circ} 01^{\prime} \mathrm{WG}$ ) (propriedade 4), com, aproximadamente, 5 anos de aplicação de composto (utilizou em 1989 e de 1994 a 1997) (Figuras 1 e 2 ). 


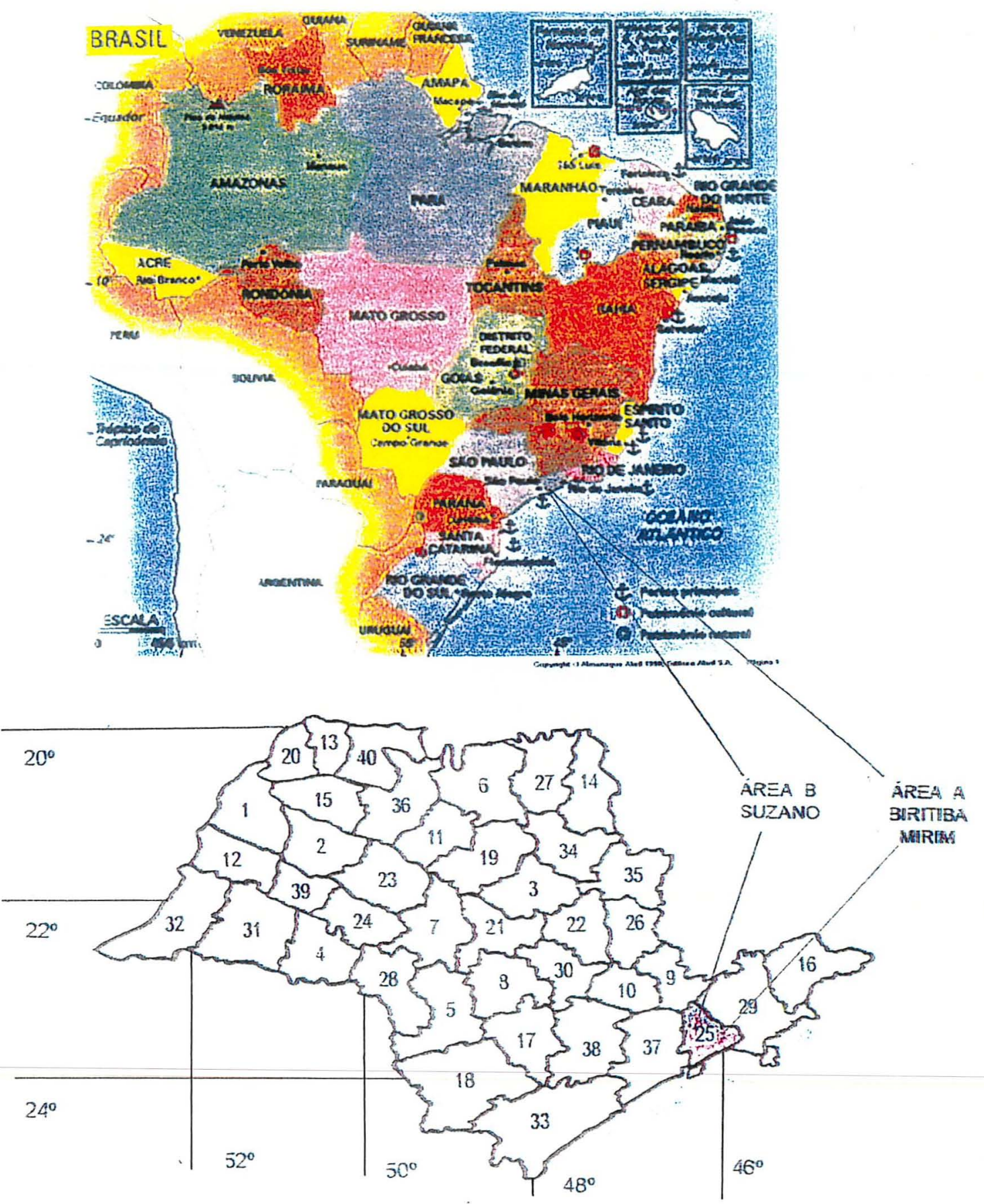

Figura 1 - Localização das áreas de estudo no Brasil e no Estado de São Paulo* "Regionais Agrícolas

1- Andradina
2- Araçatuba
3- Araraquara
4- Assis
5-
6varé
7- Barretos
8- Bauru
9- Brucatuança Pia
10- Campinas

1- Andradina

11- Catanduva

12- Dracena

13- Fernandópolis

14- Franca

15- General Salgado

16- Guarađ̇inguetá

17- Itapetininga

18- ltapeva

19- Jaboticabal

20- Jales
21- Jaú

22- Limeira

23- Lins

24- Marilia

25- Mogi das Cruzes

26- Mogi Mirim

27- Oriăndia

28- Ourinhos

29- Pindamonhangaba

30- Piracicaba
31- Pres. Prudente

32- Pres. Venceslat

33- Registro

34- Ribeirăo Preto

35- S J da Boa Vista

36- S J do Rio Preto

37- São Paulo

38- Sorocaba

39- Tupă

40- Votuporanga 


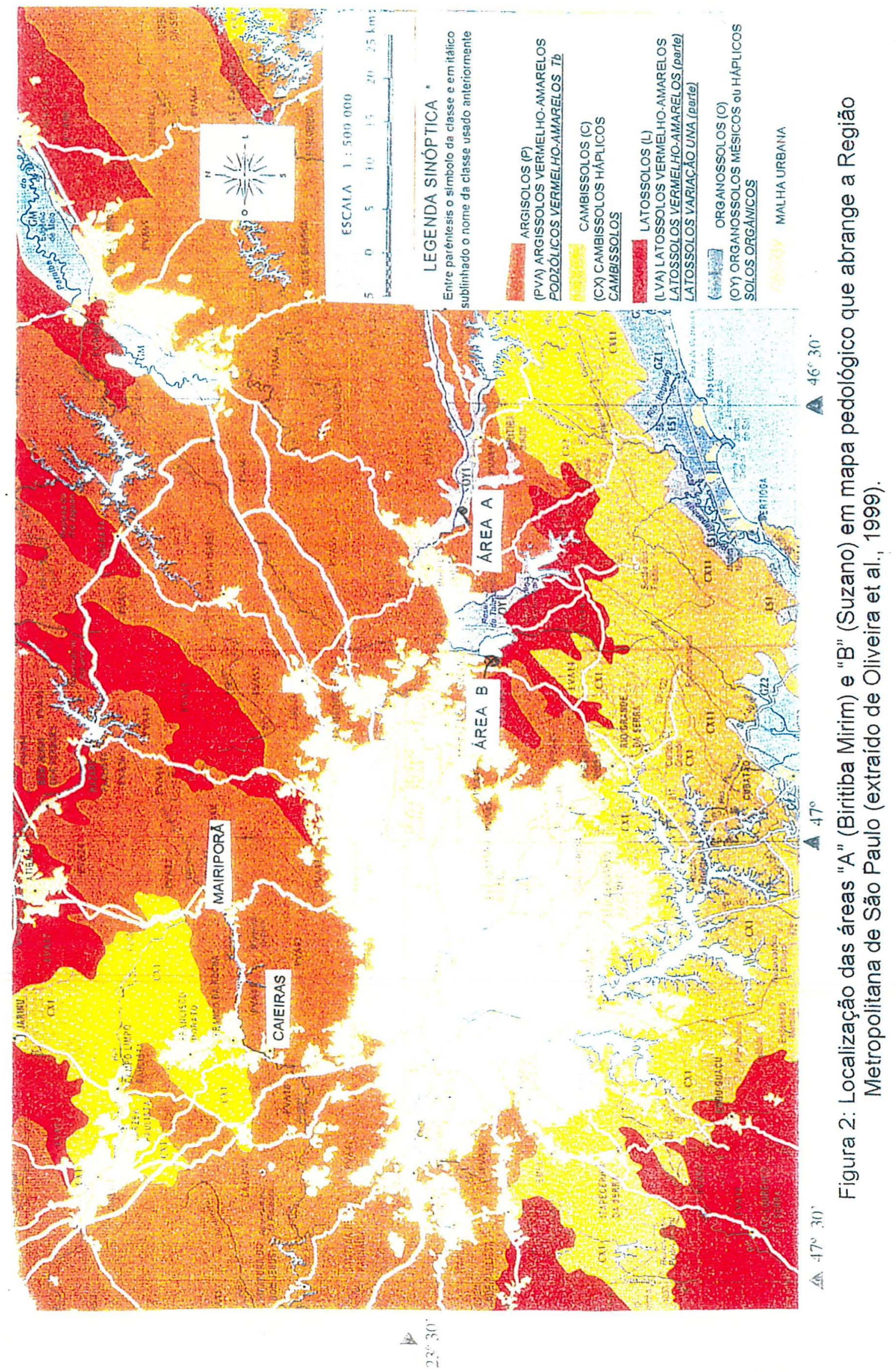




\subsubsection{Caracterização climática}

O clima da região, segundo o IBGE (1977), pode ser classificado como mesotérmico brando, variedade superúmido sem seca. Caracteriza-se por temperaturas amenas, com médias anuais de 19 a $18^{\circ} \mathrm{C}$; sendo que no inverno as mínimas oscilam entre $8^{\circ} \mathrm{C}$ e $6^{\circ} \mathrm{C}$. $\mathrm{O}$ índice pluviométrico é alto, com valor médio entre 1300 e $1400 \mathrm{~mm} \mathrm{ano}^{-1}$, com o período de chuvas mais intensas ocorrendo de dezembro a fevereiro e o período de seca no mês de junho. Segundo o Departamento de Águas e Energia Elétrica - DAEE (1972) a precipitação média de Suzano é de $1310 \mathrm{~mm}$ ano $^{-1}$ e a de Biritiba Mirim é de $1207 \mathrm{~mm} \mathrm{ano}^{-1}$.

Como os dois postos climáticos do DAEE na região estão situados em locais com microclima muito diferente das duas áreas estudadas, procedeu-se através dos dados das coordenadas geográficas e da altitude, a estimativa das temperaturas mínimas, das máximas e as médias mensais, utilizando-se o programa desenvolvido por Pedro Jr. et al. (1991). Os dados calculados são apresentadas na tabela 1 . O mesmo não foi feito para a pluviosidade em função das duas áreas de estudo serem irrigadas.

Tabela 1. Estimativa das temperaturas minimas, máximas e médias mensais, através dos dados das coordenadas geográficas e altitude, utilizando-se programa desenvolvido por Pedro Jr. et al. (1991). (Lat. $23^{\circ} 3^{\prime}$, Long. $46^{\circ} 1^{\prime}$ ', altitude $739 \mathrm{~m}$ ).

\begin{tabular}{c|c|c|c|c|c|c|c|c|c|c|c|c|c}
\hline mês & JAN & FEV & MAR & ABR & MAI & JUN & JUL & AGO & SET & OUT & NOV & DEZ & ANO \\
\hline temperatura & \multicolumn{10}{|c}{ C. } \\
\hline mínima & 17,7 & 17,9 & 17,1 & 14,5 & 11,7 & 10,2 & 9,7 & 10,9 & 12,9 & 14,7 & 15,6 & 17 & 14,1 \\
máxima & 28,8 & 28,8 & 28,4 & 26,6 & 24,6 & 23,5 & 23,7 & 25,6 & 26,6 & 27,2 & 27,8 & 27,9 & 26,6 \\
média & 23,2 & 23,4 & 22,8 & 20,5 & 18,2 & 16,8 & 16,7 & 18,3 & 19,8 & 20,9 & 21,7 & 22,4 & 20,4 \\
\hline
\end{tabular}




\subsubsection{Caracterização dos solos estudados}

As caracteristicas morfológicas foram determinadas através de levantamento de campo, seguindo as recomendaçães de coleta e interpretação de Lemos \& Santos (1984) e Oliveira et al. (1992). Para fins de classificação dos dois solos, foram realizadas em amostras coletadas do perfil análises químicas para fins de fertilidade, análises após ataque sulfúrico, granulométrica e mineralógica, conforme metodologias de, respectivamente, van Raij \& Quaggio (1981); Embrapa (1979); Kiehl (1979) e .Jackson (1969).

Os resultados são apresentados nas tabelas 2 e 3.

Para o glei húmico os minerais identificados na fração argila avaliados por difração de raios-X foram: caolinita, gibbsita e muscovita, enquanto que os da fração silte foram: quartzo, muscovita, ortoclasio e oligoclase. A análise termodiferencial da fração argila apresentou $68,5 \%$ de caulinita e $19,0 \%$ de gibbsita. O percentual de ferro determinado com oxalato foi de $0,01 \%$.

Para o solo podzólico vermelho-amarelo os minerais identificados na fração argila foram: caolinita, gibbsita, vermiculita/clorita e muscovita, enquanto que os da fração silte foram quartzo, pirofilita, ortoclasio e oligoclase. A análise termodiferencial da fração argila apresentou $32,1 \%$ de caulinita e $66,5 \%$ de gibbsita. O percentual de ferro determinado com oxalato foi de $0,16 \%$. 


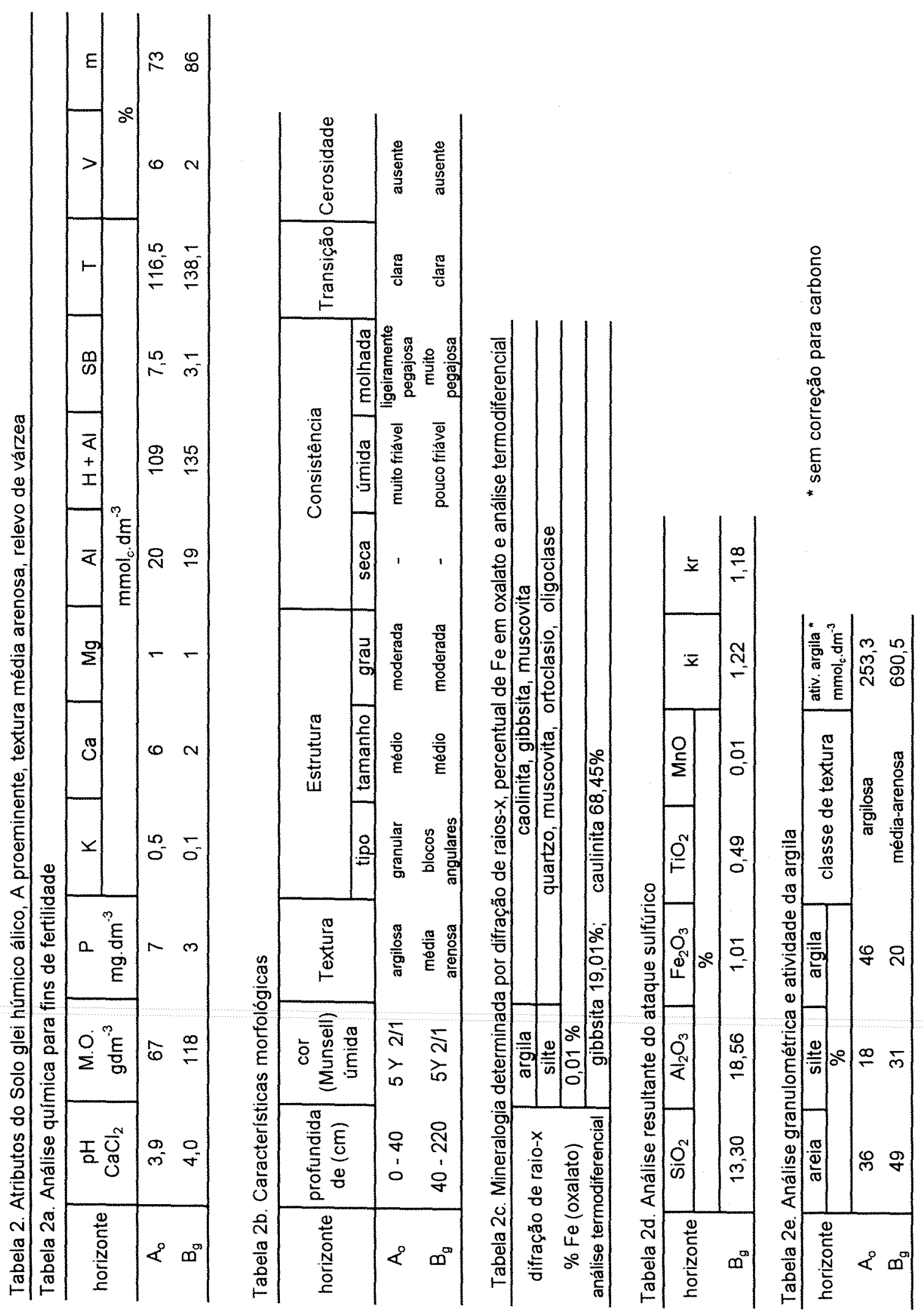




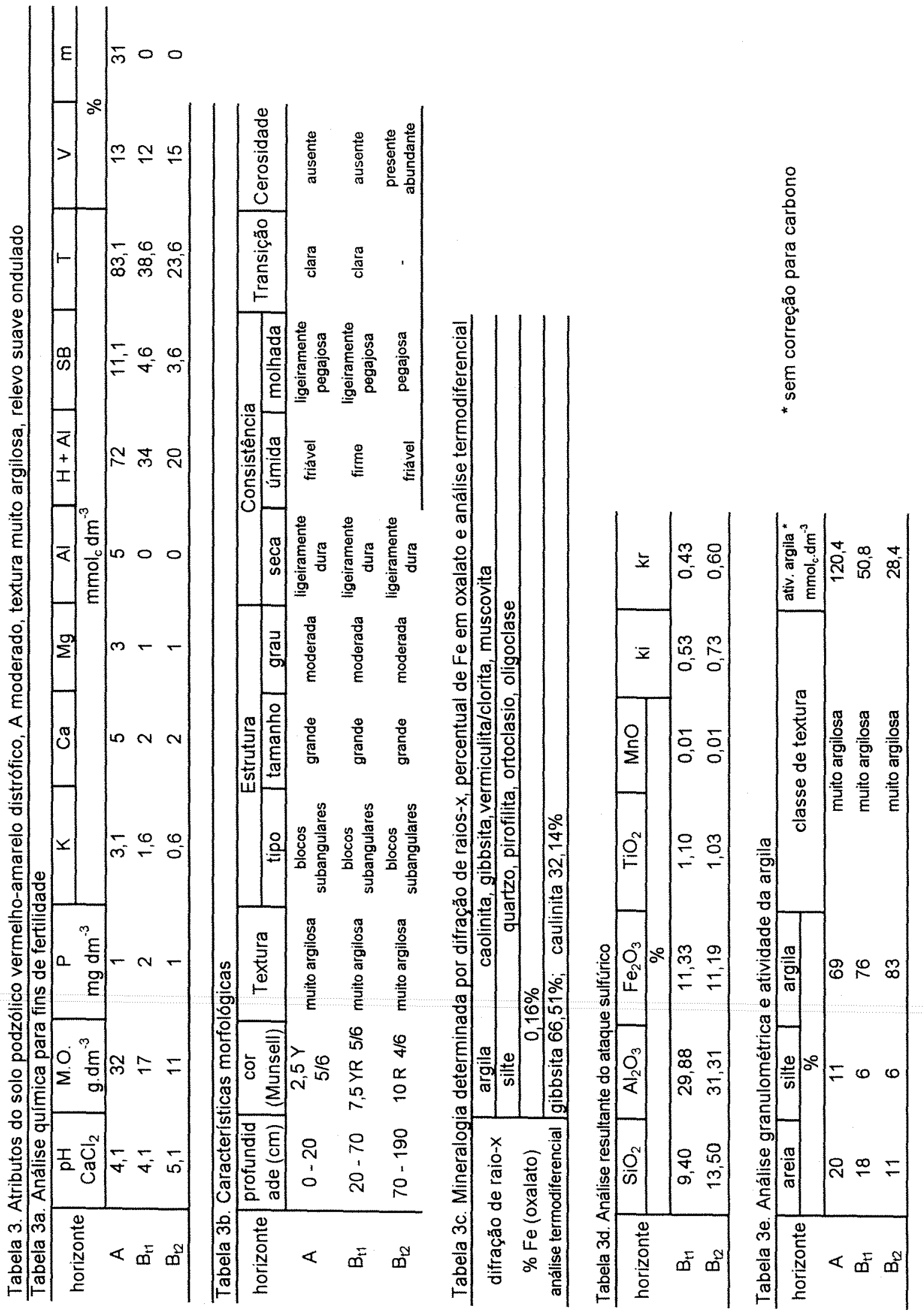


Os solos das áreas escolhidas receberam em média $200 \mathrm{~m}^{3} \mathrm{ha}^{-1} \mathrm{ano}^{-1}\left(80 \mathrm{Mg} \mathrm{ha}^{-1} \mathrm{ano}^{-1}\right.$, base seca a $70^{\circ} \mathrm{C}$ até peso constante) de CRSU, sendo procedentes das Usinas de Santo André (Santo André - SP) e São Matheus (São Paulo - SP). As concentrações de alguns elementos em compostos maturados das duas usinas, segundo acompanhamento realizado por Chitolina (1998a) durante 18 meses, são apresentados na tabela 4.

\subsubsection{Amostragem dos solos}

Para o glei húmico (propriedades 1, 2 e 3) foram realizadas amostragens em duas etapas, sendo a primeira em fevereiro de 1998 e a segunda em setembro de 1998.

Na primeira etapa as amostras na propriedade 1 foram coletadas em três áreas distintas: uma em canteiros, no momento da colheita da alface; em outros canteiros, no momento do plantio da alface (uma semana após a aplicação do composto) e numa área adjacente aos canteiros, com predominância de gramíneas, nunca cultivada anteriormente e que serviu como comparação.

$\mathrm{Na}$ segunda etapa as amostras foram coletadas no momento da colheita da alface, também em três áreas distintas: uma em canteiros onde foi aplicado composto (a mesma da primeira etapa, mas não exatamente nos mesmos canteiros - propriedade 1) e as outras duas em canteiros de áreas adjacentes, onde nunca foi aplicado CRSU (propriedades 2 e 3 ). 


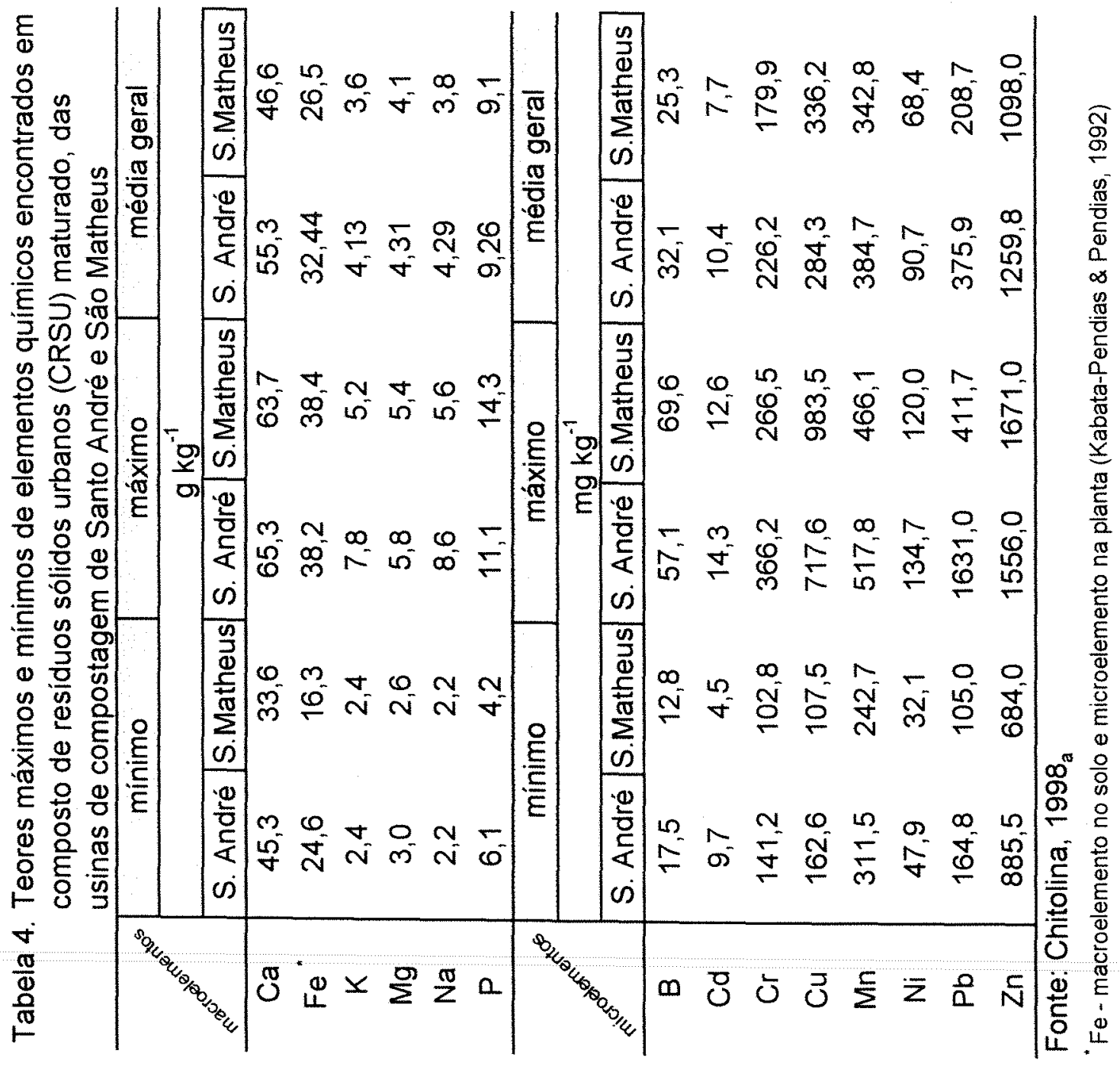


Para o podzólico vermelho-amarelo (propriedade 4) foram realizadas amostragens, numa só etapa (fevereiro de 1998), em quatro áreas distintas, ou seja, em canteiros no momento da colheita da alface, em outros canteiros no momento do plantio da alface; em outros canteiros no momento da colheita da beterraba (Beta vulgaris L.) e numa área adjacente aos canteiros, com predominância de gramíneas, não cultivada anteriormente nem foi aplicado composto e que serviu como comparação.

Na primeira etapa de coleta do glei e na única etapa de coleta no podzólico, a superficie dos canteiros amostrados correspondeu a $300 \mathrm{~m}^{2}$. A amostragem foi feita de modo a obter-se uma amostra para cada dois metros quadrados, com seis repetições. Nas áreas adjacentes às cultivadas foram coletadas 20 amostras.

$\mathrm{Na}$ segunda etapa de coleta do glei húmico obtiveram-se também amostras para cada dois metros quadrados, mas o número de repetições por área foi reduzido para quatro.

As amostras foram coletadas à profundidade de $30 \mathrm{~cm}$, que é a camada periodicamente revolvida pelos implementos e considerada a principal zona de absorção, uma vez que as hortaliças são de ciclo curto e os elementos em estudo geralmente apresentam baixa mobilidade, com exceção do boro (Gupta et al., 1985; Dudka \& Chlopecka, 1990; Dowdy et al. 1991; Giusquiani et al., 1992; Lopez \& Petruzzelli, 1993; Oliveira \& Portas, 1993; Matos et al., 1996).

Para a análise micromorfológica foram coletadas 20 amostras indeformadas do horizonte superficial $(0-30 \mathrm{~cm})$ dos dois tipos de solos.

Para análise da densidade aparente foram coletadas no glei húmico 20 amostras com anel de Kopeck de $50 \mathrm{~cm}^{3}$, conforme descrito em Kiehl (1979). 


\subsubsection{Preparo das amostras para análise}

As amostras de terra coletadas nos dois solos (1090 amostras) foram secas ao ar, trituradas, homogeneizadas individualmente e passadas em peneira de $2,00 \mathrm{~mm}$ de abertura de malha.

Com o auxílio de um cachimbo de $10 \mathrm{~cm}^{3}$ procedeu-se a obtenção das amostras compostas, seguindo-se nova homogeneização. As amostras compostas assim preparadas foram colocadas em sacos plásticos, previamente lavados, secos e identificados e armazenados em refrigerador a $5^{\circ} \mathrm{C}$ até o momento da sua utilização nas diversas análises.

\subsubsection{Atributos micromorfológicos}

Nas análises micromorfológicas foram preparadas 10 laminas de cada um dos dois tipos de solo, no Núcleo de Pesquisas em Geoquímica e Geofísica da Litosfera (NUPEGEL/USP). As amostras foram recobertas por um filme de carbono, com o auxílio do equipamento Sputter Coater S150B. Após o processo de recobrimento as amostras foram analisadas no microscópio eletrônico de varredura (MEV), para os estudos morfológicos. Análises químicas semi-quantitativas foram realizadas através de microanálise de raios- $X$ por espectrometria de energia dispersiva (EDS).

\subsubsection{Atributos microbiológicos}

Nas análises microbiológicas a biomassa microbiana foi determinada por fumigação-extração (Vance et al., 1987). Esta forma de medição da biomassa correlaciona-se significativamente com o método 
fumigação-incubação (Jenkinson \& Powson, 1976) e sendo mais rápido e menos trabalhoso, é mais aplicável a operações de rotina. É considerado um parâmetro sensivel a alterações ambientais (Rodrigues et al., 1994; Brookes, 1995; Moreno et al., 1999). Utilizaram-se nestas análises apenas amostras do glei húmico coletadas na segunda etapa.

Também para verificar se a utilização de CRSU nas condições de campo do presente estudo provocou alguma alteração na estrutura da comunidade microbiana, foi realizada a determinação do número mais provável de fungos e bactérias pelo método de plaqueamento por gotas (Jahnel, 1999), considerado sensível a adição de diferentes formas de matéria orgânica e à concentração de microelementos.

Nas áreas estudadas, a alface chega a ser cultivada quatro vezes por ano e a aplicação de fertilizantes, corretivos e pesticidas (principalmente herbicidas) é intensa, práticas que podem afetar significativamente a população microbiana (Kennedy \& Gewin, 1997; Ananyeva et al., 1999; Bardgett \& McAlister, 1999; Marchiori Jr. \& Mello, 1999; Simek et al, 1999). Desta forma, além das amostras coletadas em área não cultivada, também foram coletadas amostras em propriedades adjacentes a propriedade 1, com formas de manejo da cultura semelhantes e que nunca receberam aplicação de CRSU, visando verificar se a sua utilização esta provocando na microbiota das áreas estudadas algum efeito adicional ao uso de outras práticas agrícolas.

\subsubsection{Atributos físicos e físico-químicos}

Para verificar possíveis variações nos parâmetros físicos e físico-químicos foram determinados a densidade aparente, usando a metodologia proposta por Kiehl (1979) e a condutividade elétrica, conforme Embrapa (1979). 


\subsubsection{Teores totais e teores considerados biodisponiveis dos microelementos no solo}

As amostras compostas, obtidas conforme descrito no item 3.1.5; foram trituradas em moinho tipo Wiley, utilizando-se peneira de $0,42 \mathrm{~mm}$ de abertura de malha, seguindo-se nova homogeneização. Estas amostras foram colocadas em sacos plásticos previamente lavados, secos e identificados, e armazenadas em refrigerador a $5{ }^{\circ} \mathrm{C}$ até $\mathrm{o}$ momento das análises.

Para a determinação dos teores totais de $\mathrm{Cd}, \mathrm{Cr}, \mathrm{Cu}, \mathrm{Fe}, \mathrm{Mn}, \mathrm{Mo}$, $\mathrm{Ni}, \mathrm{Pb}$ e $\mathrm{Zn}$ optou-se por realizar a digestão nítrica-perclórica, conforme utilizada por He et al. (1995) e modificada por Chitolina (1998a).

O teor total de B não foi obtido porque significaria dobrar os extratos a serem obtidos das amostras e, devido a sua mobilidade (Gupta et al, $1985)$, este elemento não apresenta maiores problemas no que diz respeito a acumulação.

Para determinação dos teores potencialmente biodisponiveis os microelementos $\mathrm{Cu}, \mathrm{Fe}, \mathrm{Mn}$ e $\mathrm{Zn}$ foram extraídos através de DTPA (ácido dietileno triamino penta-acético), sendo o $\mathrm{B}$ extraído com água quente. Também foram feitas análises químicas para fins de fertilidade, conforme metodologia descrita em van Raij \& Quaggio (1981).

As determinações foram realizadas por espectrometria de absorção atômica, no Setor de Química, do Departamento de Ciências Exatas da ESALQ/USP. Também foram realizadas leituras através de espectrômetro de plasma induzido em argônio, com a colaboração da Seção de Fertilidade do Solo e Nutrição de Plantas, do Instituto Agronômico de Campinas, tendo sido acrescentada a determinação do Mo. 


\subsubsection{Extração seqüencial dos microelementos}

A extração seqüencial foi realizada de acordo com Tessier et al. (1979) para sedimentos fluviais, com as adaptações feitas por Chitolina (1998b) para CRSU e solos, apenas para as amostras coletadas na primeira etapa no glei húmico e para todas as amostras coletadas no solo podzólico vermelhoamarelo.

A determinação dos teores de $\mathrm{Cd}, \mathrm{Cr}, \mathrm{Cu}, \mathrm{Fe}, \mathrm{Mn}, \mathrm{Ni}, \mathrm{Pb}$ e $\mathrm{Zn}$ presentes nos extratos foi feita por espectrometria de absorção atômica.

\subsection{Plantas}

\subsubsection{Amostragem das plantas}

Foram coletadas plantas de alface (Lactuca sativa L.) e beterraba (Beta vulgaris L.). A escolha da alface justifica-se pelo fato desta espécie ser a principal hortaliça cultivada na região que recebe aplicação do composto e também pela sua alta capacidade de acumulação relativa de $\mathrm{Cd}$. A beterraba foi escolhida pela sua alta capacidade de acumulação relativa de alguns metais como o $\mathrm{Cu}, \mathrm{Ni}$ e $\mathrm{Zn}$, em relação a outras espécies vegetais, pelo fato de ter as raizes como principal parte comestivel e também porque alguns microelementos apresentam pouca capacidade de translocação nas plantas ( $\mathrm{Cd}>\mathrm{B}>\mathrm{Zn}>\mathrm{Cu}>\mathrm{Pb}$ ), vindo a concentrar-se nas raizes (Adriano, 1986; Alloway, 1995; Marschner, 1995).

Foram realizadas amostragens em duas etapas, sendo a primeira em fevereiro e março de 1998 e a segunda no mês de setembro do mesmo ano. 
Na primeira etapa, no mês de fevereiro, no mesmo momento da coleta das amostras de terra, plantas de alface cultivar verônica (alface crespa), em ambos os solos, e plantas de beterraba, (cultivar ferry moser), todas no ponto de colheita para comercialização. Em cada área amostrada $\left(300 \mathrm{~m}^{2}\right)$ cada repetição foi formada pelo conjunto de cinco plantas inteiras (raizes e parte aérea), num total de 6 repetições. A coleta no mês de março foi feita nas áreas cujas amostras de terra foram coletadas em fevereiro, com plantas no estágio de recém transplantadas ou recém germinadas. Foram coletadas no glei húmico plantas de alface, cultivar hortênsia (alface lisa) e no podzólico vermelho-amarelo foram coletadas plantas de alface, cultivar verônica (alface crespa) após 37 dias de crescimento da alface. Como o cultivo de alface no glei é feito através de mudas e no podzólico através de semeadura direta, no solo podzólico foi necessário esperar 56 dias de crescimento da alface para a coleta, época em que as plantas atingiram o ponto de colheita para comercialização.

Na segunda etapa (mês de setembro de 1998), foram coletadas plantas de alface, cultivar verônica (alface crespa), todas no ponto de colheita comercial, de maneira semelhante a coleta realizada na primeira etapa. Desta feita, foram colhidas amostras apenas da parte aérea e apenas no glei húmico, também em três áreas distintas: uma em canteiros onde foi aplicado composto (a mesma da primeira etapa, mas não exatamente nos mesmos canteiros propriedade 1) e as outras duas em canteiros de áreas adjacentes, onde nunca foi aplicado CRSU (propriedades 2 e 3 ).

\subsubsection{Preparo das plantas para análise}

As plantas de alface foram separadas em raízes, caules e folhas $e$ as de beterraba, em raízes e folhas sendo, posteriormente, cuidadosamente lavadas com água destilada. As diversas partes de cada planta foram lavadas com água destilada, deixadas por alguns minutos em 
água deionizada e novamente lavadas com água deionizada. Em seguida, as amostras compostas ( 5 plantas) foram secas em estufa de ventilação forçada, a $70^{\circ} \mathrm{C}$, até peso constante.

As amostras foram então trituradas em moinho tipo Wiley, utilizando-se peneira de $0,42 \mathrm{~mm}$ de abertura de malha, sendo a seguir homogeneizadas. Estas amostras foram colocadas em sacos plásticos previamente lavados, secos e identificados, e armazenadas em refrigerador a $5^{\circ} \mathrm{C}$ até o momento das análises.

\subsubsection{Teores dos microelementos nas plantas}

As amostras compostas obtidas conforme descrito no item 3.2.2 foram submetidas a digestão nitrica-perclórica, de acordo com Sarruge \& Haag (1974).

A determinação dos teores de $\mathrm{Cd}, \mathrm{Cr}, \mathrm{Cu}, \mathrm{Fe}, \mathrm{Mn}, \mathrm{Ni}, \mathrm{Pb}$ e $\mathrm{Zn}$ no extrato ácido foi realizada por espectrometria de absorção atômica (AAS). Também foram realizadas leituras através de espectrômetro de plasma induzido em argônio, com a colaboração da Seção de Fertilidade do Solo e Nutrição de Plantas do Instituto Agronômico de Campinas, tendo sido acrescentada a determinação do Mo.

\subsection{Análises estatísticas}

As médias dos valores obtidos nas diferentes análises foram comparadas através do teste $\mathrm{t}$. 


\section{RESULTADOS E DISCUSSÃO}

\subsection{Solos}

\subsubsection{Atributos micromorfológicos}

Os resultados da avaliação micromorfológica estão apresentados nas figuras 5 a 8 . Não foram encontradas estruturas que evidenciassem processos de neoformação, embora ocasionalmente tenha sido detectada a presença de concreções metálicas (Figuras 5 e 7) e a associação entre fosfato de cálcio e ferro (Figuras 6 e 8 ). A análise química semi-quantitativa da concreção metálica (Figura 7) poderia sugerir a presença de gibbsita ocluindo metais uma vez que a presença deste mineral é geralmente significativa em solos tropicais com cargas variáveis (Uehara \& Gillman, 1981). No entanto, a forma da concreção observada ao microscópio eletrônico (Figura 5) não corresponde ao aspecto da gibbsita.

Amarante (1997) e Mello Jr (1998), avaliando amostras de aterro contaminado com a mesma metodologia do presente estudo, constataram a presença de $\mathrm{Mn}$ associado a minerais neoformados (barita e apatita), nódulos metálicos de $\mathrm{Fe}, \mathrm{Cr}$ e $\mathrm{Ni}$, minerais de ferro com $\mathrm{Zn}$ associado e estruturas de forma esférica, com inúmeras cavidades, provavelmente de origem orgânica, que nos perfis contaminados revelaram-se uma armadilha para os microelementos. Os teores de $\mathrm{Cu}, \mathrm{Mn}, \mathrm{Pb}$ e $\mathrm{Zn}$ destes perfis contaminados, em mg kg-1, foram: Cu 35 a 560 000; Mn 60 a 71 000; $\mathrm{Pb} 16$ a 24000 e $\mathrm{Zn} 23$ a 233000 , os quais são bem mais elevados que os observados nos dois solos do presente estudo (tabela 7). 


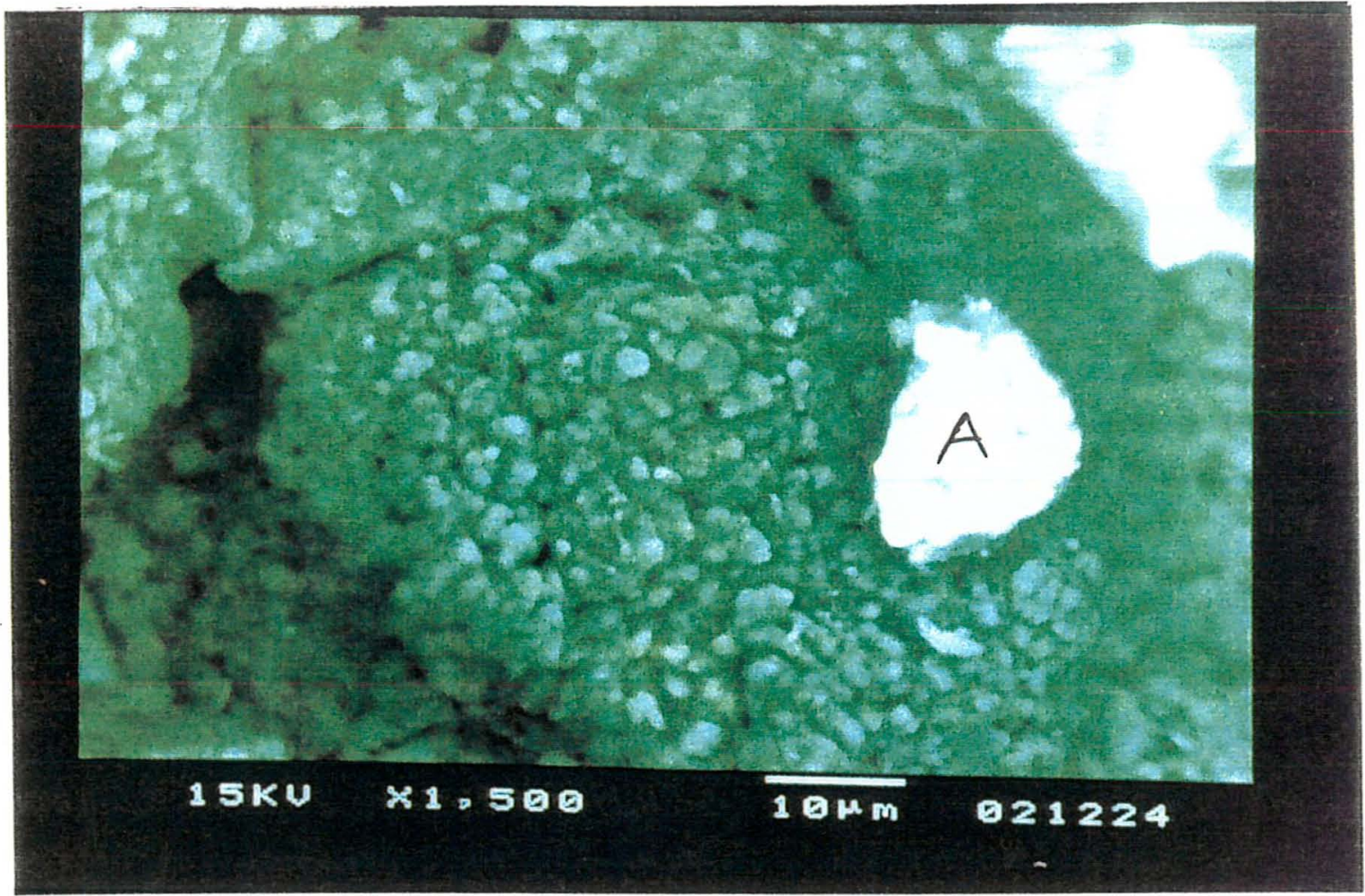

Figura 5. Imagem ao microscópio eletrônico de varredura, obtida com elétrons retroespalhados, mostrando matriz caulinítica e concreção rica em metais (ponto A) do horizonte de superfície do glei húmico $(0-30 \mathrm{~cm})$, tratado com composto de resíduos sólidos urbanos.

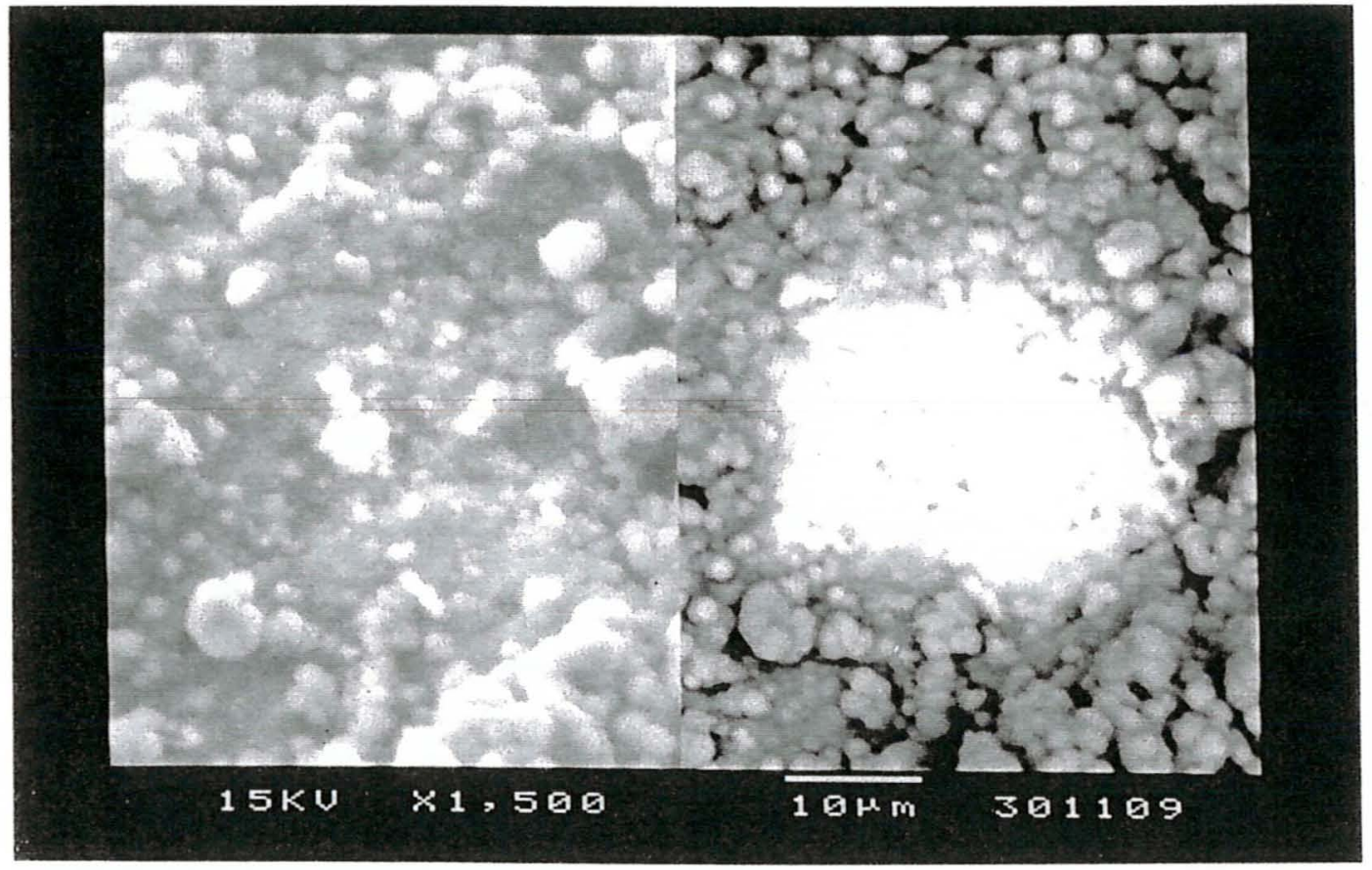

Figura 6. Fosfato de cálcio na matriz caulinítica, associado com Fe e Ti em horizonte de superfície do podzólico vermelho-amarelo $(0-30 \mathrm{~cm})$, tratado com composto de resíduos sólidos urbanos. (imagem à esquerda obtida com elétrons secundários e à direita com elétrons retroespalhados). 


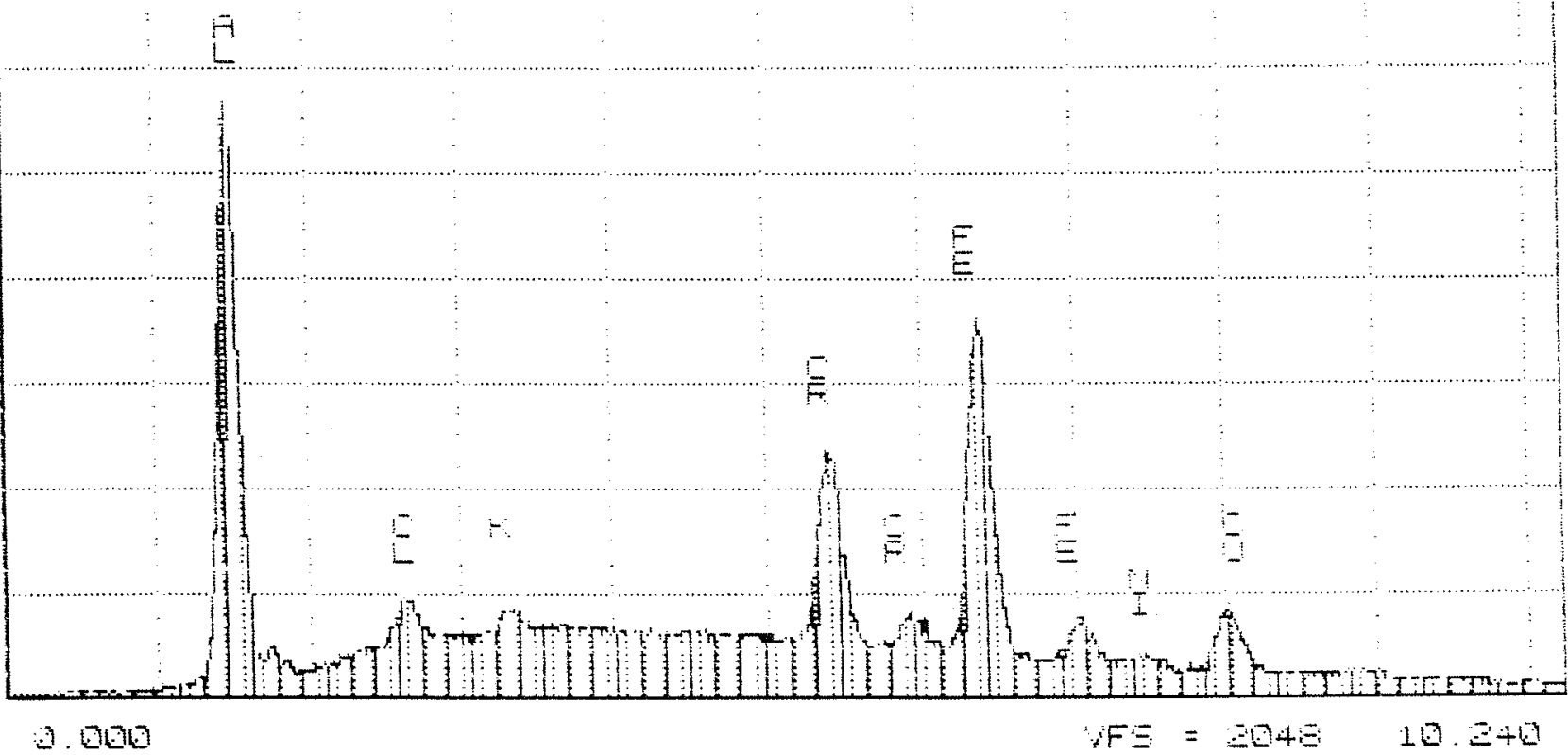

Figura 7: Análise quimica semi-quantitativa da matriz da figura 5 por espectrometria de energia dispersiva.

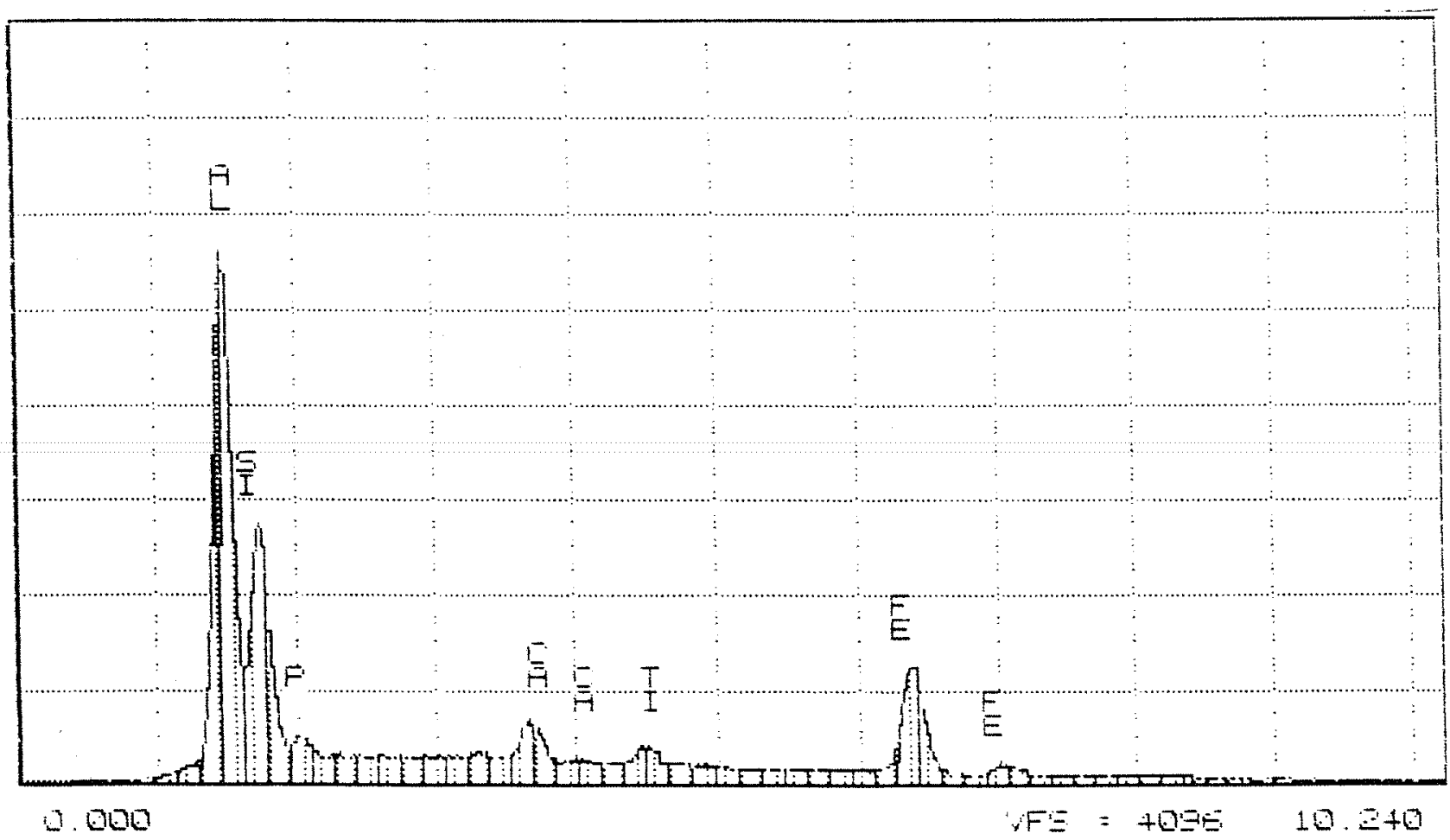

Figura 8: Análise química semi-quantitativa da matriz da figura 6 por espectrometria de energia dispersiva. 


\subsubsection{Atributos microbiológicos}

Os resultados das análises da biomassa microbiana encontram-se apresentados na figura 9. A biomassa foi maior na área de cultivo menos intensivo e menor uso de insumos, e não diferiu entre a área cultivada tratada com CRSU e a não tratada, com formas de cultivo semelhantes, não diferindo também entre área tratada com CRSU e área não cultivada $(p>0,05)$.

A ação das plantas espontâneas/invasoras e o cultivo menos intenso, mais conservadores da matéria orgânica do solo, associados ao menor uso de insumos (tabela 6), parece ter sido favorável à atividade microbiana.

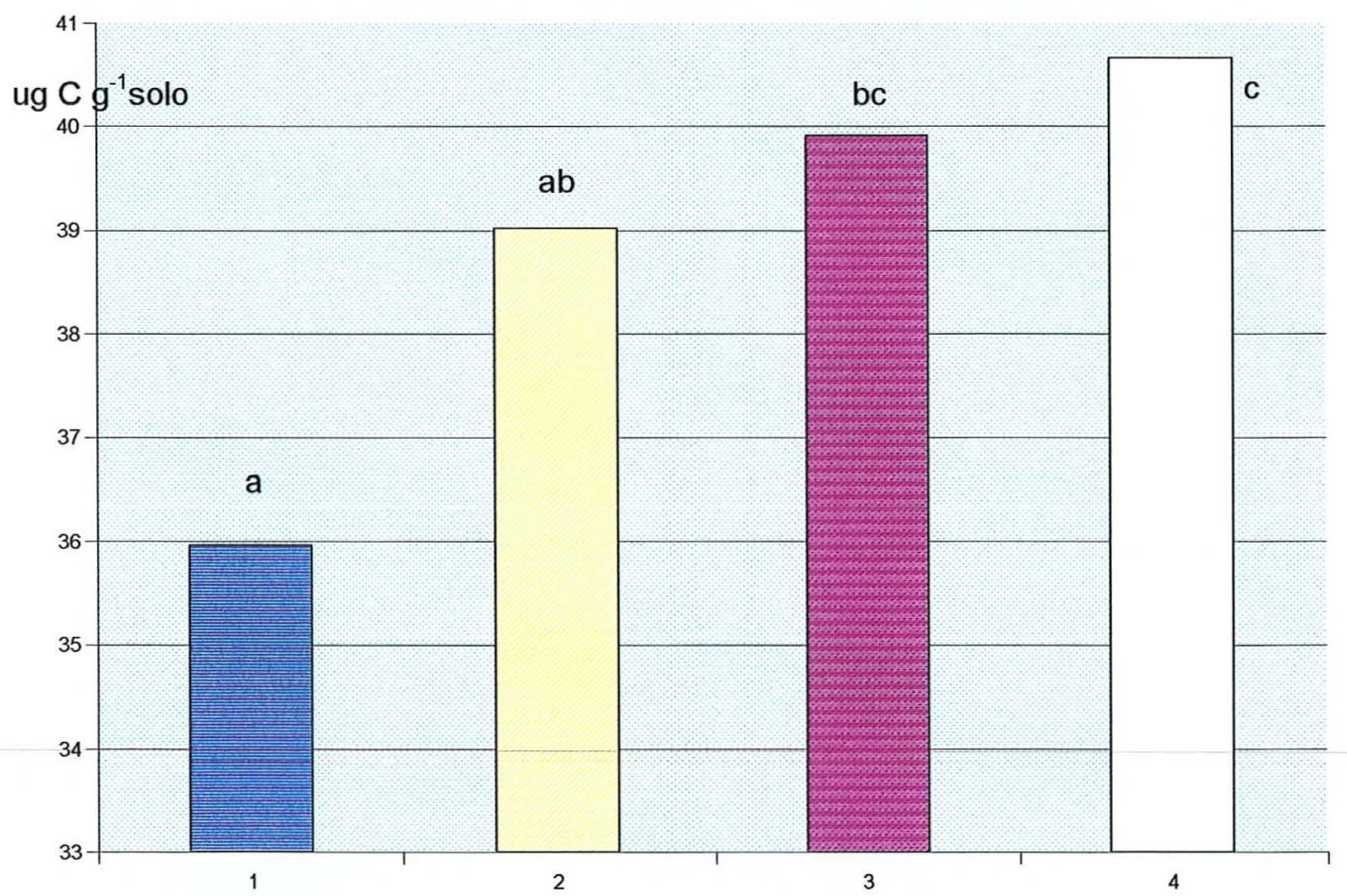

1 - solo não cultivado, com predominância de gramíneas;

2 - solo tratado com CRSU, corretivos e fertilizantes;

3 - solo tratado com corretivos e fertilizantes, sem aplicação de CRSU;

4 - solo tratado com corretivos e fertilizantes (dois anos de pousio), sem aplicação de CRSU.

Figura 9. Avaliação da biomassa microbiana de amostras coletadas no glei húmico através do método da fumigação-extração. Colunas de mesma letra não diferem a $5 \%$ de probabilidade. 
Vidor et al, (1997), em experimento conduzido a campo em solo podzólico vermelho-amarelo, durante 33 meses, observaram resultados semelhantes nas parcelas tratadas com CRSU ou fertilizante mineral prontamente solúvel, com uma tendência de aumento no número de bactérias e fungos no solo em função da quantidade de composto orgânico aplicada.

$A$ adição de CRSU proporciona um incremento na disponibilidade de substrato carbônico, o que pode mascarar o efeito de metais na biomassa microbiana, que só vem a ser afetada quando ocorre a contaminação com teores elevados de microelementos, como por exemplo, $1000 \mathrm{mg} \mathrm{kg}^{-1}$ de Cu ou Zn (Brookes, 1995; Dahlin et al.,1997).

Decréscimos na biomassa da comunidade edáfica em alguns estudos ecotoxicológicos têm sido associados a mudanças na estrutura da microbiota (Frostegard et al., 1993; Frostegard et al., 1996). A estrutura da comunidade microbiana das áreas estudadas no que diz respeito a fungos e bactérias pode ser observada na Tabela 5 . Os números mais prováveis de unidades formadoras de colônias apresentaram grande variabilidade, não tendo sido possivel observar uma tendência clara de comportamento nas oscilações da população microbiana.

A interação da biota com elementos potencialmente tóxicos (sensivel, tolerante e resistente) pode ser uma estratégia ecológica importante para a resistência e resiliência do sistema solo em resposta a alterações das condições ambientais (Doelman et al., 1994; Beare et al, 1995). Em geral, solos com maiores teores de matéria orgânica apresentam maior diversidade (Ovreas \& Torsvik, 1998). Seguindo este raciocínio, a adição de CRSU pode aumentar a concentração de teores de elementos tóxicos mas também aumenta a capacidade de suporte do sistema pelo aumento da biodiversidade.

Além disto, ocorre o incremento de outros componentes limitantes como matéria orgânica e óxidos que podem reduzir a biodisponibilidade de elementos potencialmente tóxicos (Chaney, 1994; Chaney et al., 1994; Brown et al., 1998). 
Tabela 5. Número mais provável de microrganismos em amostras do glei húmico $(0-30 \mathrm{~cm})$, determinado através do método de plaqueamento (para 5 repetições). Números seguidos de mesma letra não diferem a $5 \%$ de probabilidade.

\begin{tabular}{c|c|c|c|c}
\hline \multirow{2}{*}{ amostras * } & \multicolumn{2}{|c|}{ fungos } & \multicolumn{2}{c}{ bactérias } \\
\cline { 2 - 5 } & \multicolumn{2}{|c}{ u.f.c (unidades formadoras de colonias) } \\
\hline data de leitura & $14 /$ Set & $01 /$ Out & $14 /$ Set & $01 /$ Out \\
\hline não cultivado & $17625 \mathrm{ab}$ & $7750 \mathrm{a}$ & $18250 \mathrm{a}$ & $47500 \mathrm{a}$ \\
propriedade 1 & $6000 \mathrm{a}$ & $11750 \mathrm{ab}$ & $357500 \mathrm{~b}$ & $537500 \mathrm{~b}$ \\
propriedade 2 & $38250 \mathrm{~b}$ & $9875 \mathrm{ab}$ & $117500 \mathrm{~b}$ & $395000 \mathrm{ab}$ \\
propriedade3 & $6200 \mathrm{a}$ & $2450 \mathrm{~b}$ & $106250 \mathrm{ab}$ & $251250 \mathrm{ab}$ \\
\hline
\end{tabular}

* solo não cultivado, com predominância de gramineas, não tratado com composto (CRSU) propriedade1, tratado com CRSU, corretivos e fertilizantes propriedade 2 , tratado com corretivos e fertilizantes minerais, sem aplicaçăo de CRSU. propriedade 3, trat. com corret. e fertiliz. (dois anos de pousio), sem aplicação de CRSU.

Segundo Macnaughtom et al., (1999) concentrações tóxicas de microelementos podem induzir rápidas mudanças na comunidade microbiana. No entanto, é importante frisar que estes autores utilizaram concentrações de $\mathrm{Cd}$, Co e $\mathrm{Sr}$ de $500 \mathrm{mg} \mathrm{kg}^{-1}$, adicionados na forma de sais e, portanto, com disponibilidade muito superior a normalmente encontrada em áreas tratadas com CRSU.

Nas condições do glei húmico do presente estudo e da forma como foi utilizada a determinação do número mais provável de microrganismos desenvolvida por Jahnel et al. (1999), não foi verificada alteração da estrutura da comunidade microbiana relacionada com a utilização de CRSU. 
As enormes disparidades entre as concentrações de metais consideradas tóxicas em inúmeros estudos (Baath, 1989), refletem a complexidade dos fatores edáficos que interferem na interação destes elementos com a comunidade microbiana. Por exemplo, freqüentemente tem sido observado a grande influência do $\mathrm{pH}$ na biodisponibilidade destes elementos, pelo seu grande efeito na solubilidade e na especiação química de metais (Shuman, 1977; Sims \& Patrick, 1978; Harrison, 1987; Xian \& Shokohifard, 1989; Dudka \& Chlopecka, 1990; Wilkens et al., 1998).

Embora os teores totais de $\mathrm{Cu}$ e $\mathrm{Zn}$ nos solos glei húmico tratados com CRSU onde foram realizadas as avaliações microbiológicas sejam elevados, (Cu TOTAL $_{\text {To }} 80 \mathrm{mg} \mathrm{kg}^{-1}$ e $\mathrm{Zn}_{\text {TOTAL }}=140 \mathrm{mg} \mathrm{kg}^{-1}$ ) (tabela 7), estes elementos podem ter tido sua biodisponibilidade limitada pelos valores de $\mathrm{pH}$ observados, em torno de 6,4 (tabela 6), com seus teores sendo: $\mathrm{Cu}_{\text {DTPA }}=20 \mathrm{mg} \mathrm{kg}^{-1}$ e $\mathrm{Zn}_{\text {DTPA }}=40 \mathrm{mg} \mathrm{kg}^{-1}$ - tabela 8 .

Os teores totais de $\mathrm{Pb}$ do glei observados na propriedade 1 são elevados (120 $\mathrm{mg} \mathrm{kg}^{-1}$ - tabela 7) mas este elemento pode ser considerado pouco tóxico para a microbiota quando comparado com o $\mathrm{Cd}, \mathrm{Cr}, \mathrm{Hg}$ e $\mathrm{Zn}$ (Mariscal et al., 1995).

Além do $\mathrm{pH}$, outros mecanismos podem ser responsáveis pela resistência e/ou resiliência do sistema solo. A natureza do processo pode ser física (umidecimento/secamento), biológica (biosorção microbiana, tolerância, redundância de funções) ou química (complexação, precipitação, reconversão') (Uren, 1992; Giller et al., 1998; Seybold et al., 1999).

\subsubsection{Atributos físicos}

Os resultados da determinação da densidade aparente são apresentados na figura 10 .

\footnotetext{
${ }^{1}$ Reconversão: migração de microelementos potencialmente tóxicos (ex: Ni), ao longo do tempo de contato com o solo, para formas quimicas menos disponiveis (Uren, 1992). Este fenômeno poderia explicar a não confirmação da hipótese da bomba relógio química em ensaios de longa duraçào (Beel et al., 1991; Forstner, 1992; Chaney et al., 1994; Chang et al., 1997; Brown et al., 1998).
} 


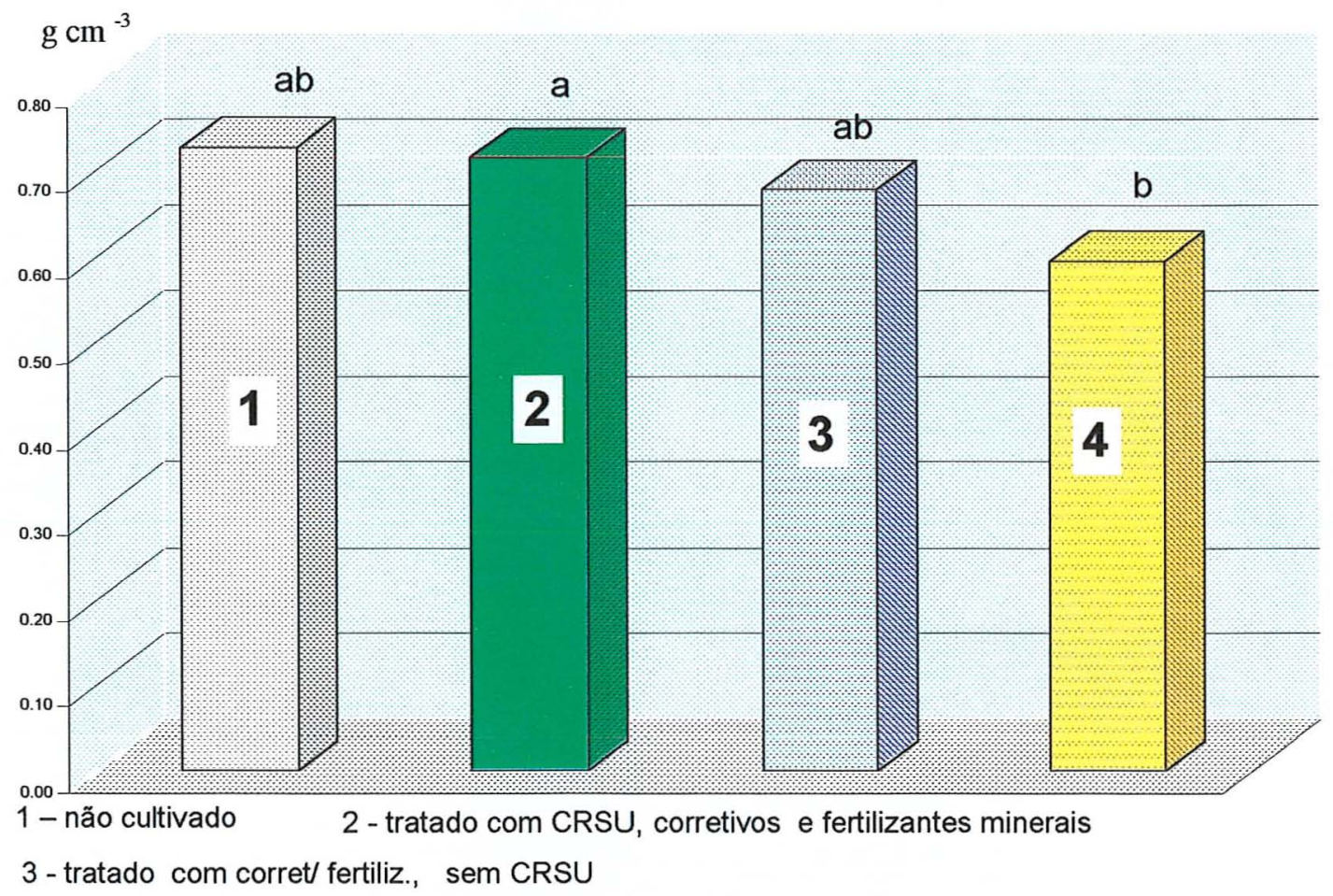

4 - tratado com corret./fertiliz. (2 anos de pousio); sem CRSU

Figura 10: Densidade aparente do glei húmico das amostras da segunda etapa.

Colunas de mesma letra não diferem a $5 \%$ de probabilidade.

$\mathrm{Na}$ área tratada com CRSU, embora com um aporte de matéria orgânica de $200 \mathrm{~m}^{3} \mathrm{ha}^{-1} \mathrm{ano}^{-1}\left(80 \mathrm{Mg} \mathrm{ha}^{-1} \mathrm{ano}^{-1}\right.$ - base seca) o efeito na densidade em relação à área não cultivada não foi significativo $(p<0,05)$, provavelmente devido ao manejo de solo adotado para o cultivo da alface, com quatro cultivos por ano, uso intensivo de enxada rotativa e também a qualidade da matéria orgânica do composto, com relação $\mathrm{C} / \mathrm{N}$ de, aproximadamente, 10 (Carmo et al., 1998). Calegari \& Pavan (1995) afirmam que os efeitos do material orgânico nas propriedades físicas depende de sua composição e da forma como é manejado e que o cultivo intensivo estimula o consumo de materiais orgânicos estabilizadores do solo pelos microrganismos.

O solo deixado em pousio durante dois anos, com posterior incorporação das plantas invasoras apresentou menor densidade aparente do 
que o solo tratado com composto $(p<0,05)$, dando indícios de que o manejo adequado destas plantas pode proporcionar diminuição na densidade aparente.

Pavan et al. (1995a) verificaram que o manejo adequado de plantas invasoras através de roçadas pode promover o incremento da agregação do solo e Pavan et al. (1995b) observaram que esta técnica proporcionou o aumento da matéria orgânica do solo, superando inclusive o uso de adubação verde, o que foi atribuído às diferentes relações $\mathrm{C} / \mathrm{N}$.

\subsubsection{Atributos físico-químicos}

Os resultados da determinação da condutividade elétrica aparecem nas figuras 11 e 12 . Observaram-se diferenças estatísticamente significativas $(p<0,05)$ entre os solos onde foi aplicado CRSU $e$ as áreas adjacentes não cultivadas, seja no solo glei húmico, seja no solo podzólico vermelho-amarelo (figuras 11a e 12).

As diferenças entre as amostras coletadas no plantio ou na colheita da alface não aparecem no solo glei, mas ocorrem no solo podzólico vermelho-amarelo. Este fato pode ser atribuído a utilização de maiores doses de adubo nitrogenado em cobertura no solo podzólico, o que também justificaria a diferença observada na área com beterraba ( Beta vulgaris L.), em relação à área com alface (Lactuca sativa L.) (figura 12).

O efeito dos fertilizantes minerais solúveis na condutividade elétrica é maior do que CRSU, conforme pode ser observado na figura $11 \mathrm{~b}$, na qual pode-se observar que a propriedade 2, que não utiliza CRSU, apresentou valores de condutividade elétrica significativamente maiores $(p<0,05)$, provavelmente devido ao uso de maiores dosagens de fertilizante mineral em cobertura.

Quanto maior o índice salino do fertilizante, maior o risco de causar dano à cultura devido ao efeito osmótico em períodos de seca ou quando o adubo é localizado muito perto ou junto a semente ou das raízes. 
a)

mmhos $\mathrm{cm}^{-1}$

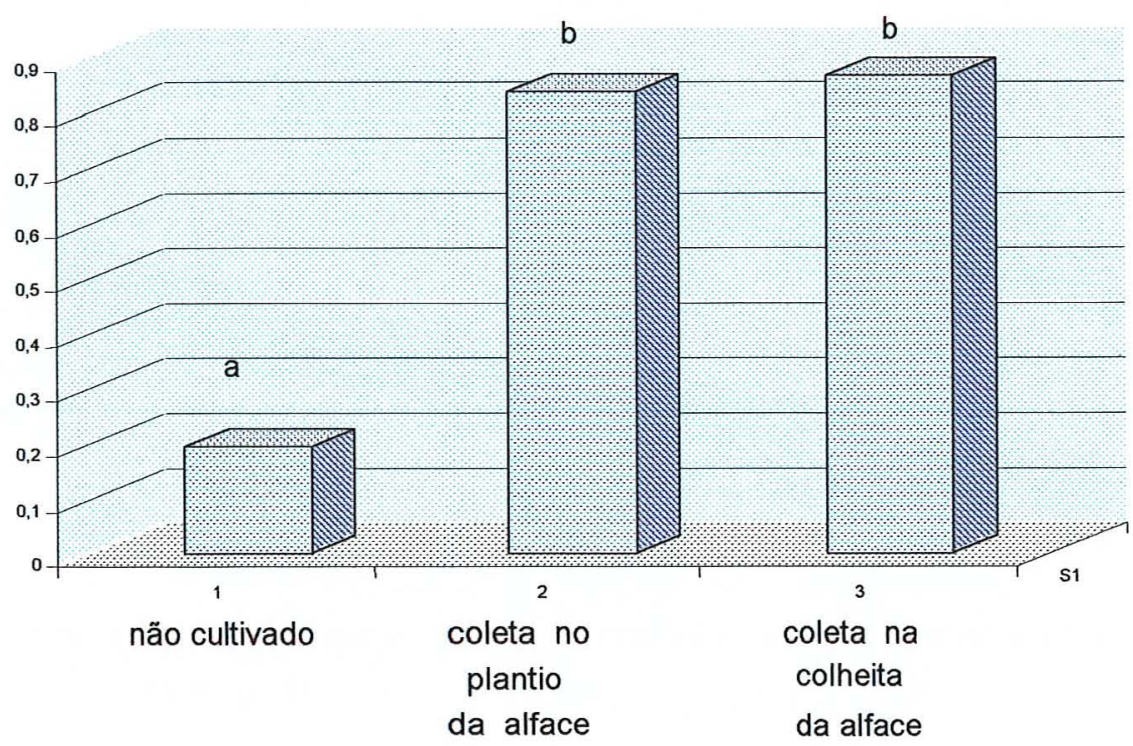

b) $\quad$ mmhos $\mathrm{cm}^{-1}$

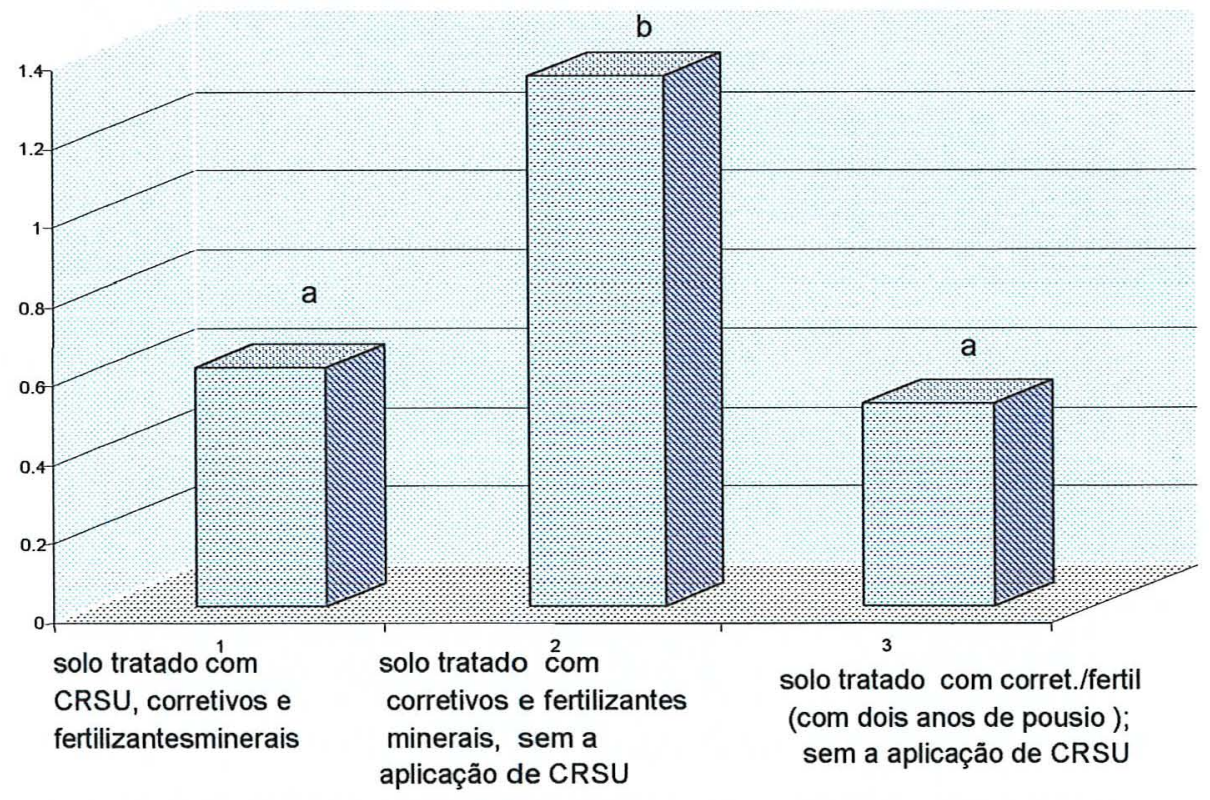

Figura 11. Condutividade elétrica do glei húmico: a) $1^{\mathrm{a}}$ etapa; b) $2^{\mathrm{a}}$ etapa.

Colunas com a mesma letra não diferem a $5 \%$ de probabilidade. 


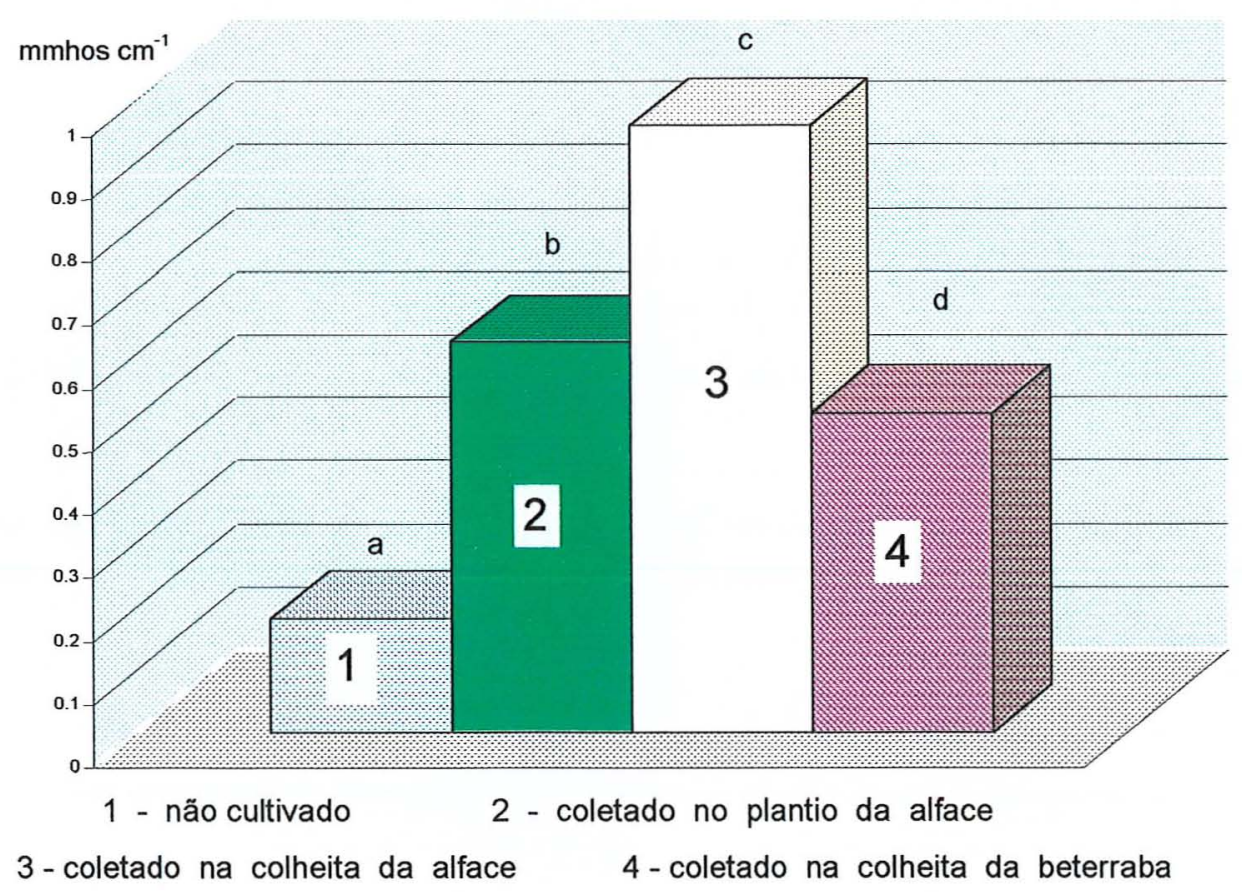

Figura 12. Condutividade elétrica do podzólico vermelho-amarelo Colunas com letras distintas diferem a $5 \%$ de probabilidade.

O índice salino relativo de alguns adubos nitrogenados em relação ao nitrato de sódio $\left(\mathrm{NaNO}_{3}=100\right)$, é o seguinte: adubos orgânicos, 3,5; nitrocálcio, 61,1; sulfato de amônio, 69,0; uréia, 75,4 e nitrato de amônio 104,7 (Malavolta,1981). Desta forma, embora utilizados em menor quantidade os fertilizantes minerais podem vir a causar maior efeito na condutividade elétrica do que os fertilizantes orgânicos, conforme pode ser observado na figura $11 \mathrm{~b}$.

As alterações na condutividade provocada pelos adubos orgânicos é bastante variável, em função da sua composição e das dosagens utilizadas e, no caso do CRSU, dos teores de $\mathrm{Na}$ e $\mathrm{K}$ (tabela 4). Behel et al. (1983) verificaram alterações provocadas pelo lodo de esgoto na

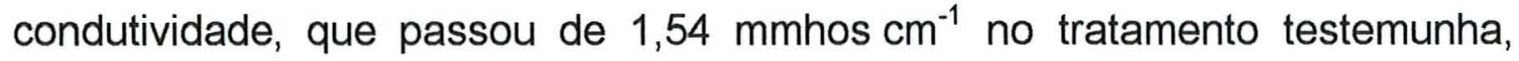
para 2,25 mmhos $\mathrm{cm}^{-1}$ (com $50 \mathrm{Mg} \mathrm{ha}^{-1}$ ) e 3,88 mmhos $\mathrm{cm}^{-1}$ (com $800 \mathrm{Mg} \mathrm{ha}^{-1}$ ). Já para o CRSU, segundo Berton (1997), mesmo na dosagem de $80 \mathrm{Mg} \mathrm{ha}^{-1}$, a

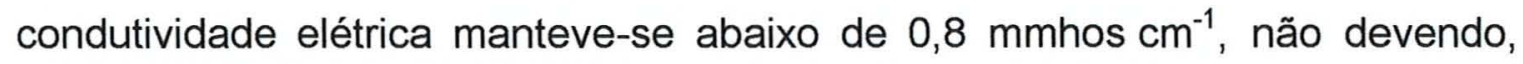
assim, prejudicar a germinação das sementes e nem o crescimento inicial das 
plantas enquanto que Costa (1994), em ensaio conduzido em vasos, verificou um aumento na condutividade elétrica de sete vezes para a dose de CRSU equivalente a $90 \mathrm{Mg} \mathrm{ha}^{-1}$.

Fassbender \& Bornemisza (1987) classificam solos com teores

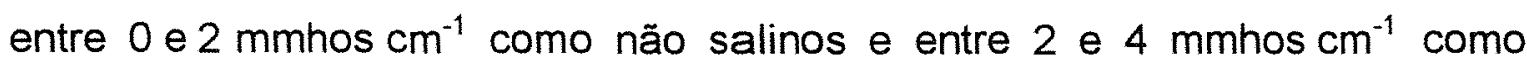
pouco salinos, onde cultivos mais sensiveis podem ser afetados. No presente trabalho, o teor médio de condutividade elétrica mais elevado encontrado foi 1,4 mmhos $\mathrm{cm}^{-1}$ o que permite classificar os solos como não salinos.

\subsubsection{Atributos químicos}

Os resultados das análises para fins de fertilidade são apresentados na tabela 6.

A avaliação dos teores totais de $\mathrm{Cd}, \mathrm{Cr}, \mathrm{Cu}, \mathrm{Fe}, \mathrm{Mn}, \mathrm{Mo}, \mathrm{Ni}, \mathrm{Pb}$ e Zn extraídos através da digestão nítrica-perclórica são apresentados na tabela 7. Para fins de comparação são apresentados os limites permitidos de teores destes elementos no solo, segundo a legislação de diversos paises europeus e segundo a legislação dos Estados Unidos (Alloway, 1995). A legislação americana é mais permissiva por ponderar as diversas vias de exposição (EPA, 1995).

Os teores considerados biodisponiveis de $\mathrm{Cu}, \mathrm{Fe}, \mathrm{Mn}$ e $\mathrm{Zn}$, extraídos através do DTPA e de $B$ extraídos através de água quente, aparecem na tabela 8. 


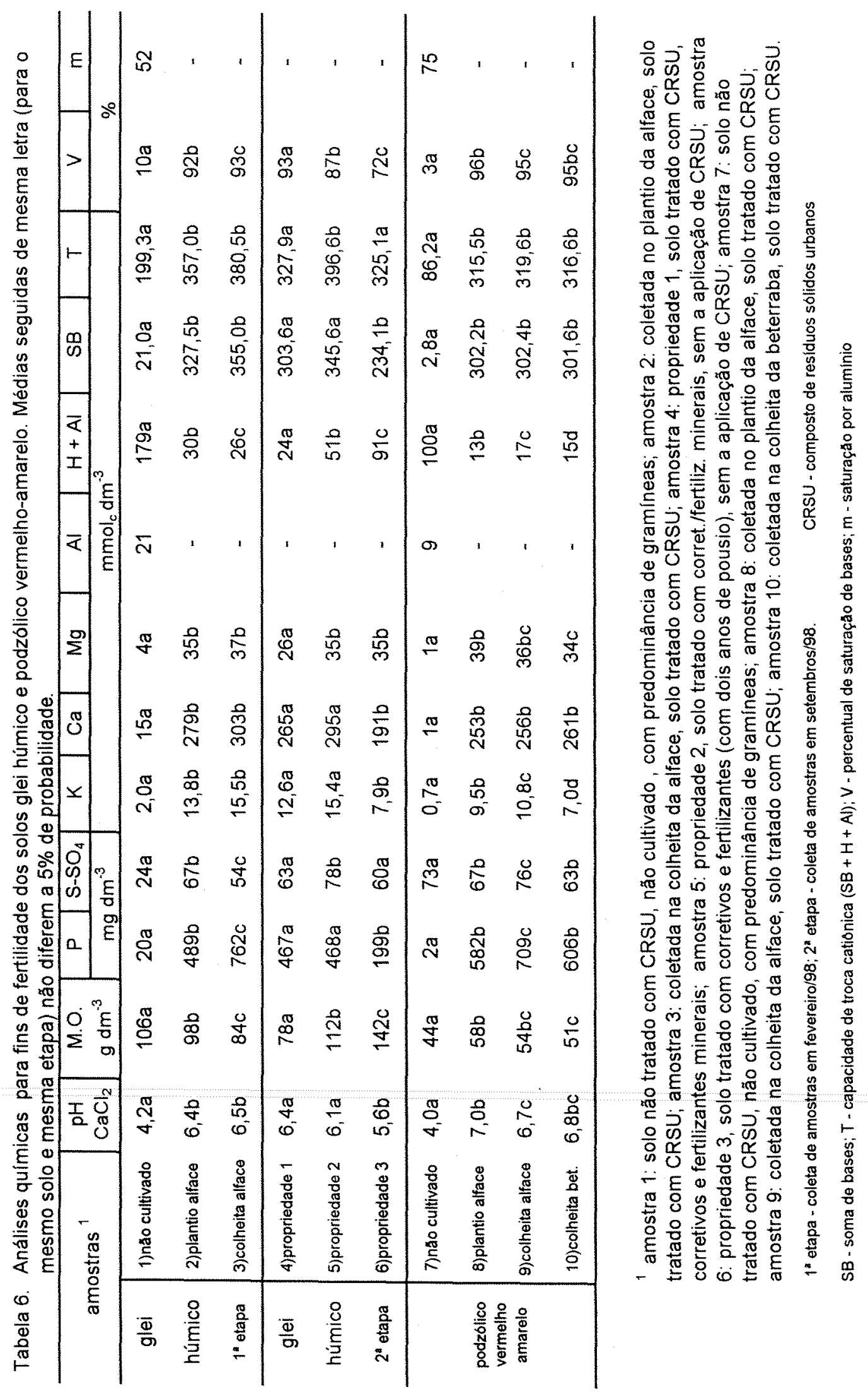




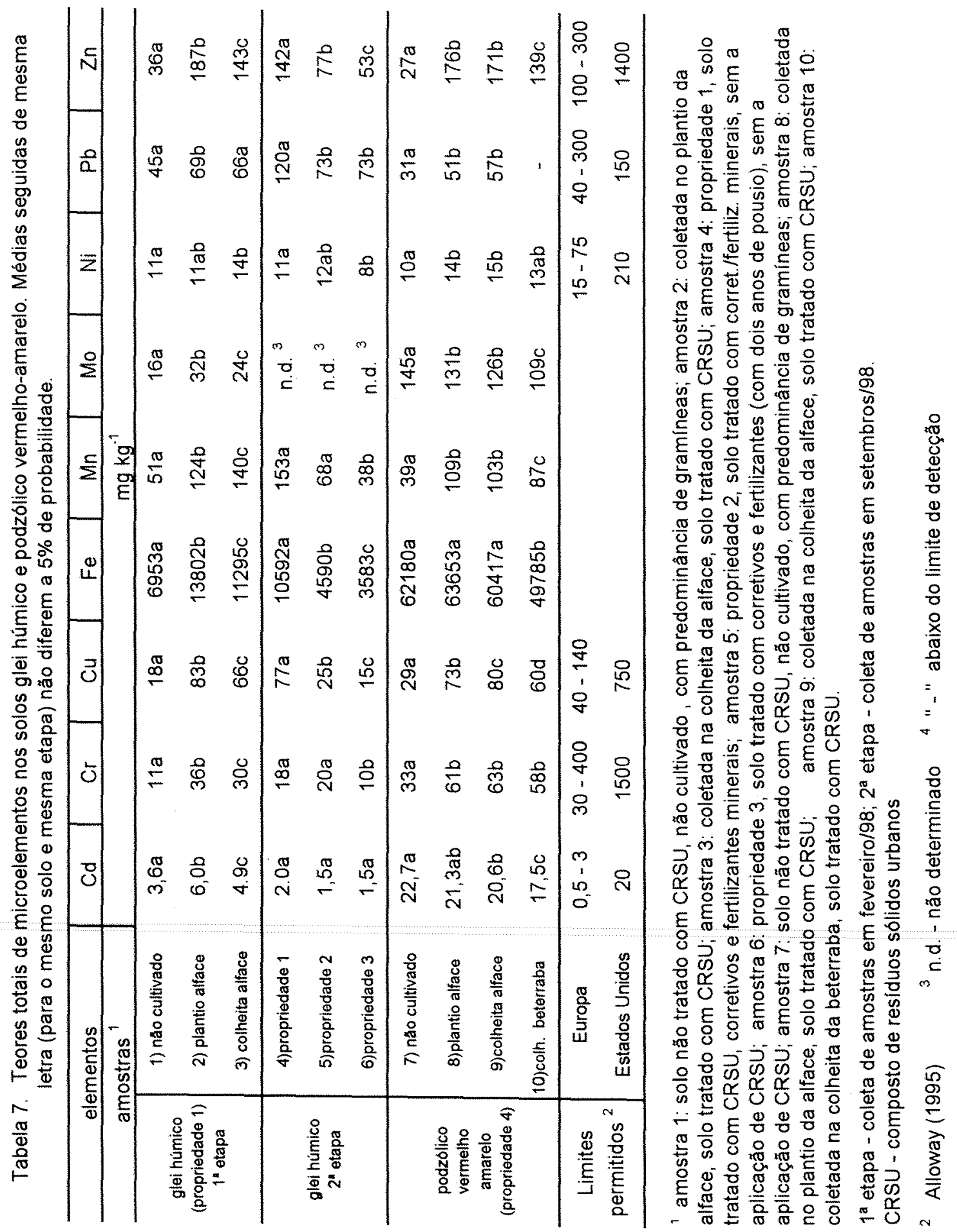


Tabela 8. Teores considerados biodisponiveis de $\mathrm{B}, \mathrm{Cu}, \mathrm{Fe}, \mathrm{Mn}$ e $\mathrm{Zn}$ nos solos glei húmico e podzólico vermelho-amarelo. Médias seguidas de mesma letra (para o mesmo solo e mesma etapa) não diferem a $5 \%$ de probabilidade.

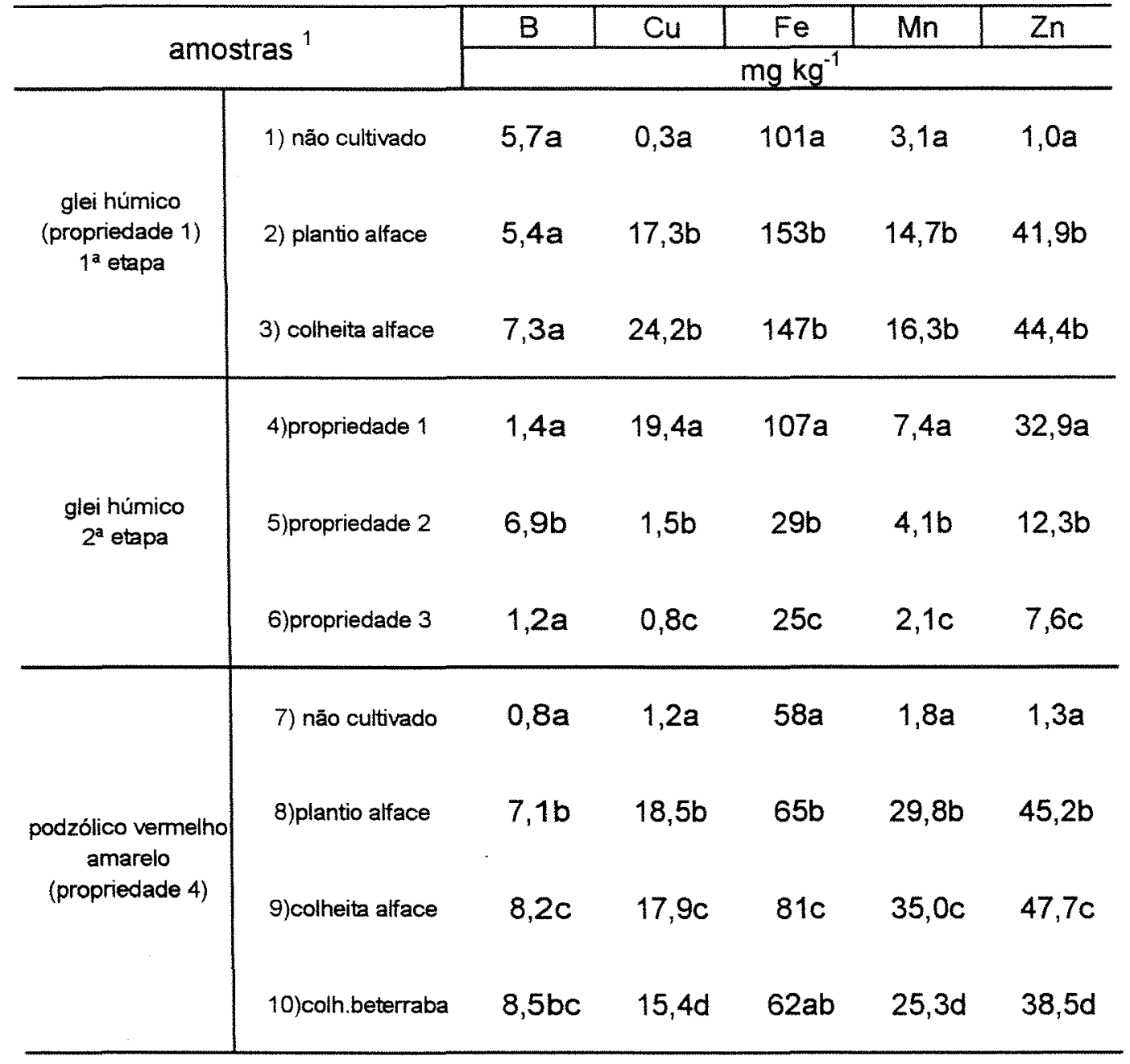

1 amostra 1: solo não tratado com CRSU, não cultivado, com predominância de gramíneas; amostra 2: coletada no plantio da alface, solo tratado com CRSU; amostra 3: coletada na colheita da alface, solo tratado com CRSU; amostra 4: propriedade 1, solo tratado com CRSU, corretivos e fertilizantes minerais; amostra 5: propriedade 2, solo tratado com corret./fertiliz. minerais, sem a aplicação de CRSU; amostra 6: propriedade 3, solo tratado com corretivos e fertilizantes (com dois anos de pousio), sem a aplicação de CRSU; amostra 7: solo não tratado com CRSU, não cultivado, com predominância de gramíneas; amostra 8: coletada no plantio da alface, solo tratado com CRSU; amostra 9: coletada na colheita da alface, solo tratado com CRSU; amostra 10: coletada na colheita da beterraba, solo tratado com CRSU. $1^{a}$ etapa (fevereiro/98); $2^{a}$ etapa (setembro/98) 


\subsubsection{Avaliação da fertilidade do solo}

Os resultados das análises para fins de fertilidade estão apresentados na tabela 6 . Os valores de $\mathrm{pH}$ e a saturação de bases (V\%) das áreas cultivadas são significativamente superiores $(p<0,05)$ aos das áreas tomadas como referência para os dois solos. Nas amostras do glei húmico coletadas na segunda etapa pode-se verificar que não houve diferença entre os valores de $\mathrm{pH}$ das propriedades 1 e $2(\mathrm{p}>0,05)$, enquanto que $\circ \mathrm{pH}$ da propriedade 3 , com dois anos de pousio e uso menos intenso de insumos, apresentou valores de $\mathrm{pH}$ significativamente menores. Efeitos semelhantes foram observados por Peixoto et al. (1987), que verificou o efeito do CRSU para a elevação do pH e por Mazur et al. (1983) que, estudando os efeitos do CRSU no pH e no alumínio trocável, verificaram uma ação simultânea do composto e do calcário para a diminuição do alumínio trocável nos solos.

Os valores da capacidade de troca catiônica $(T)$ e os das bases trocáveis $(\mathrm{K}, \mathrm{Ca}, \mathrm{Mg})$ das áreas cultivadas também foram significativamente maiores do que os das áreas tomadas como referência $(p<0,05)$. Os teores obtidos por Chitolina (1998a) na caracterização do CRSU (tabela 4) sugerem que haja participação do composto para o incremento dos teores de $\mathrm{K}, \mathrm{Ca} e$ $\mathrm{Mg}$, mas os observados no presente estudo não permitem inferir sobre a participação relativa do CRSU quando comparado aos fertilizantes minerais.

Os teores elevados de $\mathrm{T}$ e pH observados (tabela 6) podem contribuir para limitar a absorção dos microelementos, conforme já salientado em outros trabalhos (Lindsay, 1978; Mahler, et al., 1982; Lake 1987b; Xian \& Shokohifard, 1989; Lehoczky et al., 1998 ).

Os valores de $P$ das áreas cultivadas são significativamente superiores aos das áreas tomadas como referência para os dois solos $(p<0,05)$. O CRSU é considerado uma fonte pobre em $P$ (Santos et al., 1992; Peixoto et al., $1989_{a, b}$ ). Os valores observados na segunda etapa de coleta no 
glei húmico sugerem que os teores elevados de $\mathrm{P}$ das áreas avaliadas sejam provocados pelo uso intenso de fertilizantes minerais fosfatados (entre $200 \mathrm{e}$ $1400 \mathrm{~kg} \mathrm{ha}^{-1}$ a cada cultivo, chegando a até quatro cultivos por ano no caso da alface).

Os elevados teores de $\mathrm{P}$ podem restringir a absorção do $\mathrm{Cd}$, assim como a de outros microelementos como o $\mathrm{Cu}$, ० $\mathrm{Fe}, \circ \mathrm{Mo}, \circ \mathrm{Pb}$ e o $\mathrm{Zn}$, através de reações no solo e por mecanismos fisiológicos internos nas plantas, em virtude da diminuição do crescimento das raizes ou devido à redução do estabelecimento de associações micorrízicas (Bingham, 1963; Street et al., 1978; Adriano, 1986; Siqueira \& Franco, 1988; Marschner, 1995).

No podzólico vermelho-amarelo os teores de matéria orgânica das áreas tratadas com CRSU foram significativamente superiores ao da área tomada como referência $(p<0,05)$ mas, no glei húmico, o teor de matéria orgânica observado nas áreas cultivadas foi inferior ao da área de referência, a despeito de aplicações de $200 \mathrm{~m}^{3} \mathrm{ha}^{-1}$ ano $^{-1}$ de CRSU. Nas amostras do glei húmico coletadas na segunda etapa, os teores de matéria orgânica no solo tratado com CRSU (propriedade 1) foram significativamente inferiores $(p<0,05)$ aos observados nas propriedades 2 e 3 . As amostras da área deixada em pousio por dois anos, com posterior incorporação das plantas espontâneas/invasoras (propriedade 3), apresentou teores significativamente maiores que os das outras áreas $(p<0,05)$. Conforme já mencionado na discussão dos valores de densidade do solo, os resultados obtidos podem ser atribuidos ao manejo intensivo adotado e a qualidade de matéria orgânica do CRSU, com relação $\mathrm{C} / \mathrm{N}$ em torno de 10 (Carmo et al., 1998). Desta forma, o efeito benéfico normalmente atribuido ao uso de CRSU como fonte de matéria orgânica (Kiehl, 1985; Berton, 1997) dependerá da forma de manejo adotada, conforme também observado por Calegari \& Pavan (1995) para o uso de adubos verdes. 


\subsubsection{Teores de microelementos (totais e biodisponiveis)}

\subsection{Boro (teores biodisponiveis)}

Os teores de $\mathrm{B}$ biodisponíveis encontrados no presente estudo (tabela 8) podem ser considerados altos, conforme limites de interpretação sugeridos por van Raij et al. (1996).

O teor observados no glei húmico não cultivado, e no glei húmico tratado com CRSU nas amostras coletadas na primeira etapa não diferem estatísticamente $(p>0,05)$. Os teores biodisponíveis elevados da área não cultivada podem ser atribuídos à presença deste elemento no material de origem e ao $\mathrm{pH} \mathrm{4,2}$ verificado nestas áreas (tabela 6) pois, segundo Gupta (1993), o boro fica mais disponivel em valores de $\mathrm{pH}$ abaixo de 6,5.

Os teores de $B$ considerados biodisponiveis observados nas áreas cultivadas do podzólico vermelho-amarelo (tabela 8 ) foram signficativamente superiores aos teores das áreas não cultivadas $(p<0,05)$, 0 que indica que solos pobres em B podem ter um incremento bastante significativo deste elemento através da aplicação de CRSU e fertilizantes minerais.

A aplicação de fontes minerais solúveis podem ter uma influência bastante significativa nos teores de boro biodisponiveis (propriedade 2) e devido à sua mobilidade, o B pode apresentar variações sazonais, uma vez que o glei húmico tratado com CRSU (propriedade 1) apresentou na segunda etapa teores inferiores de $B\left(1,43 \mathrm{mg} \mathrm{kg}^{-1}\right)$ do que os apresentados na primeira fase $\left(5,4 \mathrm{mg} \mathrm{kg}^{-1}\right.$ e $\left.7,3 \mathrm{mg} \mathrm{kg}^{-1}\right)$.

Avaliações dos teores de B normalmente não tem sido incluídas nos estudos sobre a presença de microelementos em resíduos e o impacto da sua utilização. No entanto, Purves \& Mackenzie (1973), estudando o efeito da aplicação CRSU em algumas culturas verificaram para a dosagem de 
$100 \mathrm{Mg} \mathrm{ha}^{-1}$, um incremento no teor de $\mathrm{B}$ do solo de mais de quatro vezes (de 0,84 para $4,44 \mathrm{mg} \mathrm{kg}^{-1}$ ).

No trabalho de Purves \& Mackenzie (1974) o potencial de toxicidade do $\mathrm{B}$ superou o do $\mathrm{Zn}$, cujo teor considerado biodisponivel passou de $7,57 \mathrm{mg} \mathrm{kg}^{-1}$ para $11,63 \mathrm{mg} \mathrm{kg}^{-1}$ e também o do $\mathrm{Cu}$, cujo teor biodisponivel pouco se alterou. O teor biodisponível do B considerado fitotóxico por estes autores é $3 \mathrm{mg} \mathrm{kg}^{-1}$. A maioria das áreas amostradas no presente estudo apresentou teores de $B$ superiores a este valor (Tabela 8 ).

A mobilidade do $B$ pode ser utilizada para minimizar os efeitos tóxicos que podem advir da presença deste elemento no CRSU $\left(12,8\right.$ a $69,6 \mathrm{mg} \mathrm{kg}^{-1}$ - tabela 4). A aplicação do composto em culturas tolerantes (beterraba) ou semi-tolerantes (alface) seria outra alternativa. Uma lista da tolerância relativa de algumas culturas ao B é fornecida por Adriano (1986), que considera a utilização do $B$ extraível em água quente conveniente para verificar a disponibilidade deste elemento para as plantas, uma vez que, normalmente, $95 \%$ do $B$ total se encontra em formas não disponiveis.

\subsection{Cádmio (teores totais)}

Pode-se observar que para os teores $\mathrm{Cd}$ nas amostras coletadas no glei húmico na primeira etapa (tabela 7 ), houve um incremento significativo nos teores de $\mathrm{Cd}$ das áreas cultivadas em relação às tomadas como referência $(p<0,05)$. Em todas as áreas do glei húmico coletadas na primeira etapa verificaram-se concentrações de $C d$ superiores aos limites permitidos em paises europeus e inferiores aos admitidos pela legislação dos Estados Unidos (Alloway, 1995).

Considerando-se o teor médio de $\mathrm{Cd}$ encontrado nos compostos utilizados nas duas áreas em avaliações realizadas por Chitolina (1998 ) durante dezoito meses (9 $\mathrm{mg} \mathrm{kg}^{-1}$ - tabela 4), as aplicações 
anuais de $80 \mathrm{Mg} \mathrm{ha}^{-1}$ (720 $\mathrm{g} \mathrm{ha}^{-1} \mathrm{ano}^{-1}$ de Cd) levariam cerca de 20 anos para alcançar o menor teor de $\mathrm{Cd}$ verificado no glei húmico tratado com CRSU, o que sugere a participação de outras fontes.

Os adubos N-P-K usados no Brasil têm concentrações de $\mathrm{Cd}$ normalmente menores que as de outros paises (de $<0,03$ a $14,6 \mathrm{mg} \mathrm{kg}^{-1}$ ) (Lagenbach \& Sarpa, 1985; Amaral Sobrinho et al., 1992; Cravo et al., 1998).

Os teores de fósforo disponivel dos campos cultivados (cerca de $500 \mathrm{mg} \mathrm{dm}^{-3}$, tabela 6) refletem a utilização de altas doses de adubos fosfatados (até $1400 \mathrm{~kg} \mathrm{ha}^{-1}$ a cada cultivo, com quatro cultivos por ano). Desta forma, estes fertilizantes devem estar contribuindo para a elevação dos teores de $\mathrm{Cd}$.

Outra fonte provável de $\mathrm{Cd}$ para os solos cultivados corresponde aos corretivos. Entretanto, estes materiais normalmente possuem teores de Cd menores que os fertilizantes fosfatados (Amaral et al., 1994) e sua taxa de aplicação nas áreas estudadas é inferior (1200 a $2400 \mathrm{~kg} \mathrm{ha}^{-1} \mathrm{ano}^{-1}$ ) (tabela 6).

A participação do CRSU parece não ter sido tão relevante quanto se poderia supor a princípio, uma vez que nas amostras coletadas no glei na segunda etapa (tabela 7), os teores de Cd verificados nas amostras coletadas na propriedade 1 (solos tratados com CRSU) não diferiram das propriedades adjacentes que nunca utilizaram o composto $(p>0,05)$.

Os valores verificados nas áreas tomadas como referência no glei húmico $\left(3,6 \mathrm{mg} \mathrm{kg}^{-1}\right)$ e no podzólico $\left(22,7 \mathrm{mg} \mathrm{kg}^{-1}\right)$ estão acima dos teores encontrados em condições naturais $\left(0,01\right.$ a 2,0 $\left.\mathrm{mg} \mathrm{kg}^{-1}\right)$, acima da concentração máxima de $\mathrm{Cd}$ aceitável em diferentes países europeus 10,5 a $3,0 \mathrm{mg} \mathrm{kg}^{-1}$ ) e, no caso do podzólico, acima da concentração máxima aceitável nos Estados Unidos (20 mg kg ${ }^{-1}$ ) (Kabata-Pendias \& Pendias, 1992; Alloway, 1995; Chen et al., 1999).

No podzólico vermelho-amarelo, a média dos teores encontrados na área não cultivada foi superior a das amostras coletadas no momento da colheita da alface e não diferiu das coletadas no plantio (tabela 7). 
A área sob o cultivo da beterraba no solo podzólico apresentou teor significativamente menor do que as demais áreas $(p<0,05)$.

Entre os principais fatores que poderiam causar a redução dos teores de $\mathrm{Cd}$ nas áreas cultivadas temos a absorção pelas plantas, a lixiviação e a erosão. A exportação via absorção normalmente é baixa, menor do que $1 \%$ dos teores presentes no solo (Matthews, 1984; McGrath \& Lane, 1989). No que diz respeito à lixiviação do Cd, Mulla et al. (1980), consideraram que o elemento seja ainda menos móvel que o fósforo. Após 36 anos de aplicação de adubo fosfatado verificaram que $71 \%$ do $\mathrm{Cd}$ acumulado permaneceu na superfície $(0-15 \mathrm{~cm})$ enquanto que do $P$ acumulado apenas $45 \%$. Vários autores já constataram a mobilidade restrita do Cd (Lund et al., 1976; Brams \& Anthony, 1988; Naidu et al.,1997; Tack et al., 1999; Bertoncini \& Mattiazzo, 1999).

A erosão pode reduzir significativamente a concentração de $\mathrm{Cd}$ da camada superficial. Em ensaio conduzido durante 13 anos, Berti \& Jacobs (1998) constataram desvios de até $100 \%$, o que foi atribuido ao movimento lateral nas parcelas em que foi aplicado ou a desuniformidade nos teores do composto. No presente estudo, os tipos de solo e a topografia indicam que o processo de erosão é pouco intenso.

Uma outra possibilidade para a redução nos teores de $\mathrm{Cd}$ acumulados seria a migração do elemento para espécies químicas não solubilizáveis pela digestão nítrica-perclórica (Matthews, 1984; Martin \& Kaplan, 1998).

Chang et al. (1982) verificaram que quatro anos após cessarem as aplicações de lodo de esgoto o teor de Cd recuperado através da digestão com $\mathrm{HNO}_{3} / \mathrm{HClO}_{4}$ era de apenas 43 a $60 \%$ do total adicionado, embora não houvesse incremento do mesmo nas camadas inferiores e a absorção pelas plantas fosse menor que $1 \%$. Embora no presente estudo a digestão prévia da matéria orgânica com $\mathrm{H}_{2} \mathrm{O}_{2}$ provavelmente aumente a eficiência da extração com $\mathrm{HNO}_{3} / \mathrm{HClO}_{4}$, segundo Matthews (1984) ela não solubiliza metais precipitados ou oclusos em silicatos. Para a extração total do Cd seria 
necessária a utilização de ácido fluorídrico o que não é recomendado devido a sua alta corrosividade e dificil manuseio (Berrow \& Stein, 1983; McGrath \& Cunliffe, 1985; Abreu et al., 1996; Chitolina, 1998a).

Os menores teores de $\mathrm{Cd}$ das amostras coletadas na colheita, em relação às coletadas no plantio, observados nos dois solos, podem ser indícios do efeito do tempo de contato do elemento com a matriz solo (Matthews, 1984) e os menores teores das áreas cultivadas do podzólico vermelho-amarelo em relação à área tomada como referência podem ser um reflexo da maior intensidade do contato do $\mathrm{Cd}$ com as partículas do solo provocado pelo revolvimento periódico, fazendo com que nas áreas cultivadas a migração do $\mathrm{Cd}$ para formas menos solubilizáveis seja mais intensa (reconversão - Uren, 1992).

Os teores elevados de $\mathrm{Cd}$ nas áreas tomadas como referência (tabela 7), principalmente no podzólico vermelho-amarelo, mais inserido na região metropolitana, sugere a possibilidade de contaminação atmosférica deste elemento, hipótese levantada por Lima et al. (1995), avaliando áreas tratadas com CRSU nos municípios de Mairiporã e Caieiras (à noroeste de São Paulo - figura 2). Embora não salientado por estes autores, interessante notar que os teores de $\mathrm{Cd}$ nas áreas de referência variaram em função da cobertura vegetal (barranco $10 \mathrm{mg} \mathrm{kg}^{-1}$; eucalipto $8 \mathrm{mg} \mathrm{kg}^{-1}$ e floresta $5 \mathrm{mg} \mathrm{kg}^{-1}$ ), o que reforça a hipótese de contaminação atmosférica de $\mathrm{Cd}$ na região metropolitana de São Paulo levantada por Lima et al (1995).

O uso do Cd é relativamente recente. A partir da década de 60 começou a ser usado para prevenir a corrosão, estabilizar polímeros, aplicações em eletrônicos e pigmentos que têm grande importância na produção de plásticos, os quais chegam a ter concentrações de $\mathrm{Cd}$ da ordem de $1000 \mathrm{mg} \mathrm{kg}^{-1}$. Este elemento se torna muito volátil acima de $400^{\circ} \mathrm{C} \mathrm{e}$, então, passa a ser disperso como aerossol (Rosseaux et al., 1989; Alloway \& Ayres, 1997). Incineradores de resíduos, com temperaturas em torno de 
$1200^{\circ} \mathrm{C}$ são, portanto, uma importante fonte em potencial de Cd para a atmosfera.

Durante a incineração de resíduos domiciliares a queima de diferentes plásticos provoca a formação de complexos clorados em partículas de tamanho diminuto que podem aumentar o tempo de residência do $\mathrm{Cd}$ na atmosfera, aumentando o raio de distribuição e o risco de inalação pelo sistema respiratório dos animais (Ross, 1994b)

As emissões atmosféricas podem provocar contaminações em distâncias de até mais de $10 \mathrm{~km}$ da fonte geradora no caso de incineradores e mais de $65 \mathrm{~km}$ no caso de mineradoras, dependendo do tamanho das partículas e da topografia (Tyler,1989). Incluindo-se variáveis como condições sazonais de vento e umidade, partículas $<10 \mu \mathrm{m}$ podem ser depositadas a centenas de quilômetros da fonte geradora (Alloway \& Ayres, 1997).

Os teores elevados de $\mathrm{Cd}$ observados nas áreas tomadas como referência sugerem que a contaminação atmosférica deste elemento na região metropolitana de São Paulo deva ser melhor investigada.

\subsection{Crômio (teores totais)}

Os teores de $\mathrm{Cr}$ observadas nos dois solos (tabela 7) estão abaixo dos limites permitidos nos Estados Unidos e na Europa, com exceção dos limites da Dinamarca e Suécia ( $30 \mathrm{mg} \mathrm{kg}^{-1}$ ).

No glei húmico ( $1^{\text {a }}$ etapa) e no podzólico vermelho-amarelo pode-se notar que houve um incremento significativo $(p<0,05)$ nas áreas tratadas com CRSU, em relação às áreas tomadas como referência (tabela 7).

No glei húmico da segunda etapa não houve diferença entre os teores da propriedade 1 (que recebeu aplicação de CRSU) e propriedade $2(p>0,05)$, sugerindo uma participação significativa dos fertilizantes minerais para o teor encontrado. Na propriedade 3 , foram encontrados valores significativamente 
menores $(p<0,05)$ que os das propriedades 1 e 2 , provavelmente devido a um menor uso de fertilizantes, o que foi levantado através de entrevistas com os agricultores e pode ser verificado pelos resultados da análise química para fins de fertilidade da tabela 6 .

Aparentemente, os principais motivos para a acumulação do $\mathrm{Cr}$ são a sua baixa mobilidade (Lund et al., 1976; Lima et al., 1995; Collier et al, 1997; Barbarick, 1998) e a sua presença em fertilizantes minerais e orgânicos aplicados ao solo.

As diferenças observadas entre as médias das concentrações de $\mathrm{Cr}$ das áreas tomadas como referência no glei húmico $\left(11 \mathrm{mg} \mathrm{kg}^{-1}\right)$ e no podzólico (33 $\mathrm{mg} \mathrm{kg}^{-1}$ ) podem ser atribuídas a uma variação natural pois em função da geologia e dos processos de formação dos solos os teores de $\mathrm{Cr}$ podem variar bastante. Segundo alguns autores como valores médios pode-se considerar uma faixa de 25 a $85 \mathrm{mg} \mathrm{kg}^{-1}$ (Adriano, 1986; Kabata-Pendias \& Pendias, 1992; McGrath, 1995; Ma et al., 1997). Todas as áreas estudadas apresentaram teores dentro desta faixa.

As amostras do glei húmico tratado com CRSU coletadas na segunda etapa apresentaram teores de $\mathrm{Cr}\left(18 \mathrm{mg} \mathrm{kg}^{-1}\right)$ inferiores aos verificados na primeira etapa (30 e $36 \mathrm{mg} \mathrm{kg}^{-1}$ ), sinalizando a variação espacial da concentração deste elemento nas áreas tratadas com composto da propriedade 1.

\subsection{Cobre (teores totais e biodisponiveis)}

Os teores totais de Cu nos dois solos (tabela 7) estão abaixo dos limites permitidos nos Estados Unidos $\left(750 \mathrm{mg} \mathrm{kg}^{-1}\right.$ ) e na Europa $\left(140 \mathrm{mg} \mathrm{kg}^{-1}\right.$ ), com exceção dos limites da Alemanha, Dinamarca, Noruega e Suécia (40 a $60 \mathrm{mg} \mathrm{kg}^{-1}$ ). 
Para as amostras do glei húmico coletadas na primeira etapa, nas áreas tratadas com CRSU os teores foram maiores cerca de três a cinco vezes $(p<0,05)$ do que os da área tomada como referência e das áreas cultivadas adjacentes tratadas apenas com corretivos, fertilizantes minerais e outras fontes orgânicas que não o CRSU (esterco de galinha, torta de mamona, bagacilho de cana) (tabela 7). Estes resultados indicam que o CRSU seja 0 principal responsável pelo incremento de Cu observado.

No caso do podzólico vermelho-amarelo, os solos tratados com CRSU apresentaram teores de $\mathrm{Cu}$ de duas a três vezes maiores $(p<0,05)$ que os da área tomada como referência (tabela 7).

Os teores totais de $\mathrm{Cu}$ nos solos geralmente variam de 1 a $250 \mathrm{mg} \mathrm{kg}^{-1}$ (Adriano, 1986; Kabata-Pendias \& Adriano, 1995; Chen et al., 1999). Em solos do Estado de São Paulo, Valadares (1975) encontrou teores na faixa de 26,1 a $28,8 \mathrm{mg} \mathrm{kg}^{-1}$ para solos hidromórficos e 16,9 a $52,5 \mathrm{mg} \mathrm{kg}^{-1}$ para podzólicos vermelho-amarelos. No presente estudo, todas áreas apresentaram teores dentro da faixa mais usual segundo Baker \& Senft, (1995), que vai de 10 a $80 \mathrm{mg} \mathrm{kg}^{-1}$.

Com relação ao $\mathrm{Cu}_{\mathrm{DTPA}}$, os valores nas áreas tratadas com CRSU foram significativamente maiores $(p<0,05)$ do que os da área tomada como referência e das áreas cultivadas adjacentes tratadas apenas com corretivos, fertilizantes minerais e outras fontes orgânicas que não o CRSU.

Os teores de CuDTPA na área de referência do glei húmico $\left(0,3 \mathrm{mg} \mathrm{kg}^{-1}\right)$ foram próximos aos considerados como críticos $\left(0,20 \mathrm{mg} \mathrm{kg}^{-1}\right)$, ou seja, que induzem situações de deficiência do elemento nas plantas. Solos com altos teores de matéria orgânica, como os hidromórficos, ou ainda cujo material de origem é pobre em $\mathrm{Cu}$, como os arenosos, usualmente apresentam deficiência de Cu (Horowitz \& Dantas, 1973; McBride \& Blasiak, 1979; Reaves $\&$ Berrow, 1984). Segundo Minnich et al. (1987) a adição de $\mathrm{Cu}$ através de formas orgânicas tem uma maior capacidade de repor e manter a concentração do elemento na solução do solo do que a adição via sal. Portanto, a aplicação 
de CRSU em solos hidromórficos pode se constituir uma importante fonte de $\mathrm{Cu}$ disponivel para as plantas (Haan, 1981).

Nas áreas tratadas com CRSU avaliadas neste trabalho as

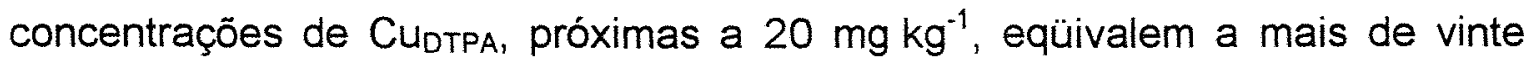
vezes o limite de teores tidos como altos por van Raij et al. (1996) podendo ser consideradas potencialmente fitotóxicas. $\mathrm{O}$ valor de $\mathrm{Cu}_{\mathrm{DTPA}}$ das áreas tratadas com CRSU também é maior do que o limite de $10 \mathrm{mg} \mathrm{kg}^{-1}$ considerado tóxico para a atividade enzimática da microbiota do solo (Baker \& Senft, 1995; Alloway \& Ayres, 1997).

Embora tenha sido constatado no presente estudo que a aplicação de CRSU aumentou significativamente os teores de CUDTPA, a interação com a matéria orgânica e os valores de pH observados nas áreas tratadas, em torno de 6,5 , podem mitigar a toxicidade do $\mathrm{Cu}$. A elevação do $\mathrm{pH}$ provocada pela aplicação do CRSU e corretivos e os mecanismos de complexação orgânica são importantes para controlar a disponibilidade e mobilidade do $\mathrm{Cu}$ (Lund et al., 1976; McBride \& Blasiak; 1979; Mazur et al., 1983; Dickinson et al., 1988; Baker \& Senft, 1995; Alloway \& Ayres, 1997; Luo \& Christie, 1997; Alves et al., 1999).

Com o aumento do $\mathrm{pH}$ diminui a solubilidade e disponibilidade do $\mathrm{Cu}$, com redução da fração orgânica e aumento das formas menos solúveis (precipitação de óxidos e hidróxidos) (Coker \& Matthews, 1983; Zhu \& Alva, 1993).

O Cu é um dos microelementos que melhor ilustra a dificuldade em predizer a resposta das plantas aos teores e formas químicas presentes no solo (Sims, 1986; Römkens et al., 1999), provavelmente devido às suas interações com a matéria orgânica, às diferentes capacidades genotípicas de absorção e a presença de associações micorrizicas (Lambert et al., 1979; Adriano, 1986). Miner et al., (1997) verificaram baixa correlação do CuDTPA com os teores em folhas de alface $(0,42)$ e alta correlação com os teores em folhas de beterraba $(0,78)$. 


\subsection{Ferro (teores totais e biodisponiveis)}

No glei húmico, os teores totais nas amostras do solos tratados com CRSU foram significativamente maiores $(p<0,05)$ que os da área de referência e também do que os solos cultivados em áreas adjacentes que nunca receberam aplicação de CRSU. No podzólico, não houve diferença $(p>0,05)$ entre as áreas cultivadas com alface tratadas com CRSU e a área adjacente, provavelmente devido aos já elevados teores naturais da área tomada como referência (tabela 6 ).

A abundância do $\mathrm{Fe}$ em rochas e solos faz com que este elemento não possa ser conceituado como microelemento nestes ambientes.

Com relação às plantas, pode ser considerado um intermediário entre os macro e micronutrientes, o que ocorre devido a pouca solubilidade de alguns de seus compostos (Fassbender, 1987), conforme pode ser observado pela diferença entre os teores de $\mathrm{Fe}_{\text {Total }}$ e Fe $\mathrm{Fe}_{\mathrm{DTP}}$ (tabelas 7 e 8)

O Fe desempenha um papel especial nos mecanismos de uma série de microelementos e, assim como o Mn, também esta envolvido com diversos processos que governam a solubilidade e disponibilidade de outros elementos (Kabata-Pendias \& Pendias, 1992; Chaney, 1993), de forma que a inclusão de sua determinação pode ser útil.

A presença de Fe no solo é muito variável. Ma et al. (1997), estudando solos da Flórida, encontraram valores entre 84 e $40000 \mathrm{mg} \mathrm{kg}^{-1}$ e no caso de solos do Estado de São Paulo pode-se atingir teores mais elevados (podzólico vermelho amarelo $30000 \mathrm{mg} \mathrm{kg}^{-1}$; latossolo roxo $137500 \mathrm{mg} \mathrm{kg}^{-1}$; terra roxa $224000 \mathrm{mg} \mathrm{kg}^{-1}$ - Jacinto et al., 1969, citado por Mello et al., 1989).

Haan (1981), em experimentos com mais de 50 anos de aplicação de CRSU em solos arenosos e argilosos, observou que, em média, os teores de $\mathrm{Fe}$ dobraram. Lima et al. (1995), em solos podzólico vermelho amarelo com 4 e 16 anos de aplicação do CRSU, da mesma forma que no 
podzólico do presente estudo, não encontraram diferenças entre as áreas tratadas e as áreas tomadas como referência.

A exemplo do que acontece nos solos e em corretivos e fertilizantes (Amaral Sobrinho et al., 1992; Raven \& Loeppert, 1997; Gabe \& Rodella, 1999) a concentração de Fe no CRSU é também bastante variável, indo de 1420 a $52145 \mathrm{mg} \mathrm{kg}^{-1}$ (Hernandez et al., 1992; Ayuso et al., 1992; Abreu et al., 1996; He et al, 1995; Chitolina, 1998; Cravo et al., 1998). O incremento ou não dos teores de Fe em função da aplicação de CRSU estará associado a estas variações.

Os resultados obtidos no presente estudo revelam que a aplicação do CRSU aumentou significativamente $(p<0,05)$ os teores de Fe DTPA nos dois solos, principalmente no glei húmico.

\subsection{Manganês (teores totais e biodisponiveis)}

Os teores totais e os extraíveis em DTPA foram maiores nas áreas tratadas com composto de resíduos sólidos urbanos (CRSU) do que nas áreas tomadas como referência para os dois solos $(p<0,05)$ (tabelas 7 e 8 ).

Nas amostras do glei húmico coletadas na segunda etapa comparando os teores de $\mathrm{Mn}$ do solo tratado com CRSU e corretivos e fertilizantes minerais (propriedade 1), com os que nunca receberam aplicação do composto (propriedades 2 e 3 ), os valores MnDTPA foram superiores $(p<0,05)$ na área com aplicação do composto. Os teores de Mntotal da propriedade 1 foram maiores que os da propriedade $3(p<0,05)$, mas não diferiram estatisticamente dos valores observados na propriedades 2 $(p=0,051)$.

A propriedade 3 , a que utiliza uma menor quantidade de insumos, foi a que apresentou os menores teores de Mntotal e Mn DtPA Os resultados sugerem que o CRSU contribui de forma considerável para o 
incremento dos teores de $\mathrm{Mn}$ e que os corretivos e fertilizantes minerais também (tabelas 7 e 8 )

O teor total de Mn no solo pode variar de 3 a $11500 \mathrm{mg} \mathrm{kg}^{-1}$, podendo ser encontrado de forma uniformemente distribuida ou acumulado no perfil ou subsolo (Muraoka, 1984; Adriano, 1986; Reisenauer, 1988; Smith \& Paterson, 1995; Ma et al., 1997).

Em outros trabalhos sobre acúmulo de microelementos no solo provocados por CRSU, Lima et al. (1995) e Collier et al., 1997 verificaram incrementos significativos e que o Mn concentrou-se nas camadas superiores.

Para solos com o pH entre 5,8 e 6,8, como os observados nas áreas cultivadas amostradas no presente estudo, O DTPA pode ser o melhor extrator para determinar o Mn biodisponível (Camargo et al., 1982; Adriano, 1986). A diferença estatística do MnDTPA observada entre as quatro áreas coletadas no solo podzólico sugerem elevada dinâmica deste elemento (tabela 8).

Segundo Adriano (1986) para uma nutrição vegetal equilibrada a relação $\mathrm{Fe}: \mathrm{Mn}$ deve ser mantida entre 1,5 e 2,5.

As relações Fe:Mn dos solos estudados aparecem na tabela 9.

Tabela 9. Relação Fe: Mn extraiveis em DTPA nos solos glei húmico e podzólico vermelho-amarelo

\begin{tabular}{c|c|c|c|c|c}
\hline \hline amostras & $\mathrm{Fe}: \mathrm{Mn}$ & amostras & $\mathrm{Fe}: \mathrm{Mn}$ & amostras & $\mathrm{Fe}: \mathrm{Mn}$ \\
\hline glei não cultivado & 32 & glei * propr. 1 & 14 & podzól. não cultivado & 32 \\
glei * plantio alface & 10 & glei * ${ }^{*}$ propr. 2 & 7 & podzól. * plantio alface & 2 \\
glei * colheita alface & 9 & glei ** * propr. 3 & 11 & podzól. * colheita alface & 2 \\
& & & & podzól. * colheita bet & 2 \\
\hline \hline
\end{tabular}

* solo com aplicação de CRSU, corretivos e fertilizantes minerais

** solo com aplicação de corretivos e fertilizantes minerais, sem aplicaçäo de CRSU

*** solo com aplicação de corret./fertiliz. minerais, sem aplicação de CRSU ( 2 anos de pousio)

Embora os valores de Mn extraídos em DTPA possam ser considerados altos (van Raij et al., 1996), sua absorção deverá ser limitada, pela presença do $\mathrm{Fe}$, principalmente no solo glei. 
A matéria orgânica do CRSU, por servir de fonte de elétrons para reações redutoras e de substrato para microrganismos que atuam na dinâmica do Mn (Reisenauer, 1988), pode estar contribuindo para uma maior disponibilidade do elemento nas áreas tratadas com o composto (tabelas 8 e 9 ).

A importância da presença do $\mathrm{Fe}$ e do $\mathrm{Mn}$ nos resíduos urbanos, para limitar a absorção e mobilidade de elementos potencialmente tóxicos e, os efeitos da relação Fe:Mn para o equilibrio nutricional das plantas, sugerem que, na medida do possivel, estes elementos sejam incluídos em estudos futuros.

\subsection{Molibdênio (teores totais)}

No glei húmico os teores totais de Mo dos solos tratados com CRSU foram significativamente maiores do que as da área tomada como referência $(p<0,05)$ (tabela 7$)$. Como o Mo não pode ser determinado nas amostras do glei húmico coletadas na segunda etapa, na comparação com áreas cultivadas que nunca utilizaram CRSU, a participação relativa das fontes minerais e do CRSU não pode ser estimada.

No podzólico vermelho-amarelo, os teores de Mo dos solos onde foi aplicado CRSU foram significativamente menores do que os da área tomada como referência $(p<0,05)$ (tabela 7$)$. Verifica-se também que os teores de Mo observados nas amostras obtidas na colheita da beterraba, de ciclo mais longo, foram menores do que os verificados na cultura da alface $(p<0,05)$.

$O$ teor de Mo verificado na área tomada como referência no glei húmico (16 mg kg-1) esta acima do observado em histosols e outros solos orgânicos (de 0,3 a 4,6 mg kg-1) e o teor do podzólico (145 mg kg-1) esta muito acima dos teores observados em solos derivados de sedimentos modernos (latossolo vermelho escuro e amarelo; podzólico vermelho-amarelo), em levantamento realizado no Estado de São Paulo (de 0,79 a $3,73 \mathrm{mg} \mathrm{kg}^{-1}$ ), ou ainda, do que os encontrados normalmente em condições naturais (de 0,1 a 
$40 \mathrm{mg} \mathrm{kg}^{-1}$ ) (Bataglia et al., 1976; Freedman \& Hutchinson, 1981; Matthews, 1984; Adriano, 1986; Kabata-Pendias \& Pendias, 1992; Chen et al., 1999).

Mesmo ocorrendo na forma aniônica, o Mo tende a acumular-se na camada superficial devido a associação com a matéria orgânica do solo ou presença de argila consolidada e pela baixa taxa de absorção deste elemento pelas plantas (Thornton, 1981; Matthews, 1984; Adriano, 1986; Barbarick et al., 1998). Este comportamento poderia justificar o acumulo de teores elevados no presente estudo, mesmo nas áreas cultivadas, irrigadas e com valores de $\mathrm{pH}$ de cerca de 6,5 (tabelas 6 e 7 ).

Não se encontrou uma explicação satisfatória para explicar teores de Mo superiores nas áreas de referência do que nas áreas cultivadas no podzólico vermelho-amarelo podendo-se, porém, aventar a possibilidade de deposição atmosférica.

A contaminação do solo via deposição atmosférica pode ocorrer pela mobilização do Mo, presente em combustiveis fósseis, durante os processos de combustão fazendo com que as concentrações atmosféricas

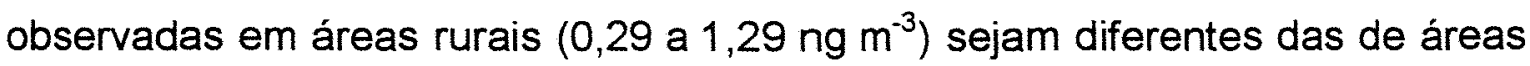
industriais (2 a $18 \mathrm{ng} \mathrm{m}^{-3}$ ) (Edwards et al., 1995).

A deposição atmosférica pode ser responsável por concentrações elevadas de Mo em solos (acima de $38 \mathrm{mg} \mathrm{kg}^{-1}$ ) (Kabata-Pendias \& Pendias, 1992). No presente estudo, enquanto que no glei húmico os teores de Mo variaram de 16 a $32 \mathrm{mg} \mathrm{kg}^{-1}$, sendo os maiores valores observados nas áreas tratadas com CRSU, no podzólico, mais inserido na região metropolitana (figura 2), os teores variaram de 109 a $145 \mathrm{mg} \mathrm{kg}^{-1}$, sendo o maior valor observado na área não cultivada.

Assim como para o $\mathrm{Cd}$, a possibilidade de contaminação atmosférica de Mo deve ser melhor investigada. 


\subsection{Niquel (teores totais)}

Os teores de Ni observados estão abaixo dos limites permitidos na Europa e Estados Unidos. Em algumas áreas cultivadas esteve próximo ou no limite estabelecido por legislações mais restritivas (Dinamarca e Suécia, $15 \mathrm{mg} \mathrm{kg}^{-1}$ - Tabela 7).

Em levantamento realizado no Estado de São Paulo os teores de $\mathrm{Ni}$ estiveram entre $<10$ e $127 \mathrm{mg} \mathrm{kg}^{-1}$. Em solo hidromórfico foi de $49 \mathrm{mg} \mathrm{kg}^{-1}$ e em podzólico vermelho-amarelo, $23 \mathrm{mg} \mathrm{kg}^{-1}$ (Rovers et al., 1983). Os teores observados nos solos do presente estudo estão abaixo destes valores.

No glei húmico os teores de $\mathrm{Ni}$ das amostras coletadas na colheita da alface da área tratada com CRSU foram significativamente maiores do que a área tomada como referência $(p<0,05)$ mas para as amostras coletadas no plantio esta diferença não ocorreu. Nas amostras do glei húmico da segunda etapa o teor de Ni observado na propriedade 1, tratada com CRSU, foi superior ao da propriedade 3 , onde nunca foi aplicado CRSU $(p<0,05)$, mas não diferiu dos valores observados na propriedade $2(p>0,05)$, que também nunca utilizou CRSU (tabela 7).

No podzólico vermelho-amarelo, os teores encontrados nas áreas de cultivo da alface tratadas com CRSU foram significativamente maiores do que os da área tomada como referência $(p<0,05)$. Os da área cultivada com beterraba não diferiram estatisticamente da área tomada como referência $(p>0,05)$ (tabela 7$)$.

O Ni normalmente apresenta pouca mobilidade no solo, acumulando-se nas camadas superficiais. Sua mobilidade no solo aumenta a medida que o pH e a CTC diminuem. (Doner et al., 1978; McGrath, 1987; McGrath, 1995; Collier et al., 1997; Barbarick et al., 1998; Berti \& Jacobs, 1998). Considerando-se os atributos verificados nos dois solos do presente estudo, 0 Ni deverá ter mobilidade limitada nos solos cultivados, tendendo a acumular-se. 
Os resultados obtidos sugerem que, tanto o CRSU quanto outras fontes minerais ou orgânicas devem ter participação no incremento do teor de Ni das áreas cultivadas em relação às áreas tomadas como referência.

Nos trabalhos sobre os efeitos do emprego de CRSU por longos períodos, para aplicações de 1948 a 1971 de $20 \mathrm{Mg} \mathrm{ha}^{-1} \mathrm{ano}^{-1} \mathrm{em}$ solos arenosos e argilosos, Haan (1981), verificou, em média, um incremento nos teores de $\mathrm{Ni}$ de 2,8 vezes. Em solos glei pouco húmico, Collier et al. (1997) encontraram diferenças significativas entre as áreas tratadas com CRSU e as áreas controle. Em solos podzólico vermelho-amarelo da Grande São Paulo não foram observadas diferenças significativas entre as áreas tratadas com CRSU e as áreas controle, mesmo para doses de $400 \mathrm{Mg} \mathrm{ha}^{-1} \mathrm{ano}^{-1}$, durante 16 anos (Lima et al., 1995; Lima \& Menck, 1997). No presente estudo as áreas cultivadas apresentaram um incremento significativo nos teores de $\mathrm{Ni}(p<0,05)$ em relação às áreas tomadas como referência, com exceção da área em que as amostras foram coletadas no plantio da alface (glei húmico) e na colheita da beterraba (podzólico vermelho-amarelo).

\subsection{Chumbo (teores totais)}

As concentrações observadas no presente estudo (de 31 a $120 \mathrm{mg} \mathrm{kg}^{-1}$ ), são inferiores aos limites permitidos nos Estados Unidos e na Europa, com exceção dos países de legislação mais restritiva, com limites entre 40 e $60 \mathrm{mg} \mathrm{kg}^{-1}$ (Dinamarca, Finlândia, Noruega e Suécia).

No Brasil, utilizando o modelo "C-soil" (legislação holandesa), Dias et al. (1998) calcularam que o valor de intervenção para cenários agricolas seria de $160 \mathrm{mg} \mathrm{kg}^{-1}$. Todas as áreas avaliadas no presente estudo apresentaram valores inferiores a este valor.

No glei húmico os teores de $\mathrm{Pb}$ das amostras coletadas no plantio da alface da área tratada com CRSU foram significativamente maiores do que a área tomada como referência $(p<0,05)$ mas para as amostras 
coletadas na colheita esta diferença não ocorreu. Nas amostras do glei húmico coletadas na segunda etapa, os teores da área tratada com CRSU foram significativamente superiores $(p<0,05)$ aos das áreas cultivadas adjacentes, que nunca receberam aplicação de CRSU (tabela 7).

No podzólico vermelho-amarelo, os teores das amostras coletadas nas áreas cultivadas com alface e tratadas com CRSU foram significativamente maiores do que os da área tomada como referência $(p<0,05)$. As amostras coletadas no momento da colheita da beterraba apresentaram problemas analiticos de determinação, não sendo possivel obter os resultados.

Dentre os elementos avaliados $\circ \mathrm{Pb}$ foi $\circ$ que apresentou maiores variações. Para algumas áreas, notadamente para as coletadas na primeira etapa, o desvio padrão foi elevado (glei coletado na colheita da alface, média $\mathrm{Pb}=66 \mathrm{mg} \mathrm{kg}^{-1}$; desvio padrão $=31 \mathrm{mg} \mathrm{kg}^{-1}$; podzólico não cultivado, média $\mathrm{Pb}=31 \mathrm{mg} \mathrm{kg}^{-1}$; desvio padrão $=19 \mathrm{mg} \mathrm{kg}^{-1}$ ).

Os teores de $\mathrm{Pb}$ nas amostras do glei húmico da propriedade 1 tratadas com CRSU coletadas na segunda etapa foram cerca de duas vezes os da primeira etapa $\left(120 \mathrm{e} 60 \mathrm{mg} \mathrm{kg}^{-1}\right)$. Este fato pode ser atribuído a variabilidade espacial do elemento ou a problemas de determinação analítica. O período de armazenamento a $5^{\circ} \mathrm{C}$ entre a digestão e a leitura dos teores de $\mathrm{Pb}$ na absorção atômica, maior no caso das amostras de primeira etapa, pode ter contribuído para uma maior variação nestas amostras. Chaney \& Ryan (1993) ponderam que problemas analíticos podem contribuir para uma maior variabilidade do $\mathrm{Pb}$ em trabalhos sobre CRSU.

Nos compostos utilizados nas áreas estudadas $\mathrm{Pb}$ é 0 elemento que apresenta maior variação (105 a $1631 \mathrm{mg} \mathrm{kg}^{-1}$ - tabela 4).

Nos solos, os teores de $\mathrm{Pb}$ também podem ser muito variáveis (de 10 a $1200 \mathrm{mg} \mathrm{kg}^{-1}$ ), dependendo principalmente do material de origem e das fontes antropogênicas. Normalmente amostras de solos orgânicos apresentam teores médios mais elevados $\left(30 \mathrm{mg} \mathrm{kg}^{-1}\right)$ que outros grupos de 
solos $\left(13 \mathrm{mg} \mathrm{kg}^{-1}\right)$. Em solos agricolas de pomares de frutas o uso de pesticidas $\left(\mathrm{PbHAsO}_{4}\right)$ pode provocar a elevação dos teores de $\mathrm{Pb}$ a valores próximos de $900 \mathrm{mg} \mathrm{kg}^{-1}$. (Adriano, 1986; Kabata-Pendias \& Pendias, 1992; Davies, 1995; Ma et al., 1997; Chen et al., 1999).

No caso do presente estudo, o incremento verificado nos teores de $\mathrm{Pb}$ nas áreas tratadas com CRSU em relação às áreas tomadas como referência e também em comparação às áreas cultivadas adjacentes que nunca receberam aplicação do composto, sugerem que o CRSU possa ser o principal responsável pelo aumento nos teores de $\mathrm{Pb}$.

Em outros trabalhos que avaliaram o efeito da aplicação de CRSU por longos períodos, Collier et al. (1997) verificaram que a aplicação de $40 \mathrm{Mg} \mathrm{ha}^{-1}$ de CRSU durante 11 anos fizeram com que o teor de $\mathrm{Pb}$ da camada de 0 a $30 \mathrm{~cm}$ de um solo glei pouco húmico passasse de 10,4 para $22,3 \mathrm{mg} \mathrm{kg}^{-1}$. Lima et al. (1995) em podzólico vermelho-amarelo observou que o teor de $\mathrm{Pb}$ foi de $8,6 \mathrm{mg} \mathrm{kg}^{-1}$ em solo sob floresta, $38 \mathrm{mg} \mathrm{kg}^{-1}$, em média, em outras áreas tomadas como referência e nas áreas tratadas com CRSU variou de 11,4 a $55,7 \mathrm{mg} \mathrm{kg}^{-1}$. Assim como nos trabalhos destes autores, nos resultados do presente estudo foi possível constatar a contribuição do CRSU para 0 incremento da concentração de $\mathrm{Pb}$ no solo e também grande variabilidade espacial dos teores deste elemento.

\subsection{Zinco (teores totais e biodisponiveis)}

Os teores totais de $\mathrm{Zn}$ nos dois solos $\left(27\right.$ a $187 \mathrm{mg} \mathrm{kg}^{-1}$ tabela 7) estão abaixo dos limites permitidos nos Estados Unidos e na Europa, com exceção das áreas tratadas com CRSU em relação a países com legislação mais restritiva, com limites entre 100 e $150 \mathrm{mg} \mathrm{kg}^{-1}$ (Dinamarca, Finlândia, Noruega e Suécia). 
Nas amostras do glei húmico coletadas na primeira etapa, os teores totais de $\mathrm{Zn}$ das áreas tratadas com CRSU foram significativamente superiores aos da área tomada referência $(p<0,05)$, (de quatro a cinco vezes maiores). Nas amostras do glei húmico coletadas na segunda etapa os teores totais de $\mathrm{Zn}$ das áreas tratadas com CRSU foram significativamente superiores $(p<0,05)$ aos das áreas cultivadas adjacentes tratadas apenas com corretivos, fertilizantes minerais e outras fontes orgânicas que não o CRSU (de 1,8 a 2,7 vezes maiores - tabela 7 )

No caso do podzólico vermelho-amarelo, os solos tratados com CRSU também foram significativamente superiores aos da área tomada referência $(p<0,05)$ (de quatro a cinco vezes maiores - tabela 7 ).

Os teores totais de $\mathrm{Zn}$ no solo normalmente variam de 10 a $300 \mathrm{mg} \mathrm{kg}^{-1}$, sendo os teores médios em solos aluviais superiores aos de outros tipos de solos (Coker \& Matthew, 1983; Kabata-Pendias \& Pendias, 1992; Kierkens, 1995; Kparmwang et al., 1998).

Em levantamento realizado no Estado de São Paulo, Valadares \& Catani (1975) verificaram teores de $\mathrm{Zn}$ em solos derivados de materiais aluviais e coluviais (glei) entre 53 e $84 \mathrm{mg} \mathrm{kg}^{-1}$ e, para solos derivados de sedimentos modernos (podzólico vermelho-amarelo), foram observados teores entre 29 e $65 \mathrm{mg} \mathrm{kg}^{-1}$. Muraoka (1984) observou em solos podzólicos, teores de $\mathrm{Zn}$ de 20 e $30 \mathrm{mg} \mathrm{kg}^{-1}$. As concentrações verificadas nas área tratadas com CRSU no presente estudo, estão acima dos teores observados por estes autores para solos glei e podzólico, indicando a influência da adição do CRSU.

Haan (1981) avaliando solos argilosos e arenosos que receberam $20 \mathrm{Mg} \mathrm{ha}^{-1} \mathrm{ano}^{-1}$ de 1948 a 1975, verificaram que $\circ \mathrm{Zn}$ foi o elemento que sofreu o maior incremento nos teores totais no solo $( \pm 4,5$ vezes). Collier et al. (1997), avaliaram áreas de solo glei pouco húmico que receberam aplicações de $40 \mathrm{Mg} \mathrm{ha}^{-1} \mathrm{ano}^{-1}$ de CRSU durante 11 anos e verificaram um incremento significativo dos teores de $\mathrm{Zn}$ nas áreas tratadas em relação às 
áreas controle (47 e $23 \mathrm{mg} \mathrm{kg}^{-1}$ ), semelhantemente ao verificado no presente trabalho.

Observando a tabela 7 podemos verificar que nas amostras da segunda etapa a área tratada com CRSU (propriedade 1) teve um incremento de $\mathrm{Zn}$ superior às outras áreas cultivadas, não tratadas com o composto. Estas áreas (propriedades 2 e 3), apresentaram teores maiores que os das áreas tomadas como referência, o que sugere a participação de outras fontes no fornecimento de $\mathrm{Zn}$ que não o composto.

Os teores de ZnDTPA das áreas tratadas com CRSU nos dois solos ( $\pm 40 \mathrm{mg} \mathrm{kg}^{-1}$ ), foram significativamente superiores aos observados nas áreas não cultivadas tomadas como referência $\left( \pm 1 \mathrm{mg} \mathrm{kg}^{-1}\right)$ e também do que os teores das áreas cultivadas adjacentes que nunca receberam aplicação de CRSU ( 8 e $12 \mathrm{mg} \mathrm{kg}^{-1}$ - tabela 8 ). Estes teores de $\mathrm{Zn}_{\text {DTPA }}$ podem ser considerados altos, segundo os limites de interpretação sugeridos por van Raij et al. (1996) ( > 1,2 $\mathrm{mg} \mathrm{kg}^{-1}$ ) mas estão bem abaixo do limite crítico de $\mathrm{Zn}_{\text {EDTA }}$ sugerido por Alloway (1995) (130 $\mathrm{mg} \mathrm{kg}^{-1}$ ). Os teores obtidos em DTPA e EDTA podem ser correlacionados, sendo os valores obtidos em DTPA ligeiramente superiores(Beckett, 1989).

Os valores de $\mathrm{pH}$ observados nas áreas tratadas com CRSU no presente estudo $( \pm 6,5)$, portanto, podem estar limitando a biodisponibilidade do $\mathrm{Zn}$ uma vez que a disponibilidade do $\mathrm{Zn}$ é mais influenciada pelo $\mathrm{pH}$ do que outros metais $(\mathrm{Zn}>\mathrm{Cd}>\mathrm{Pb}>\mathrm{Cu}$ ) (Lagerwerff et al., 1977).

\subsubsection{Extração seqüencial}

Os teores dos elementos e seu percentual em relação a soma das frações para os solos glei húmico e podzólico vermelho-amarelo são apresentados na tabela 10. 


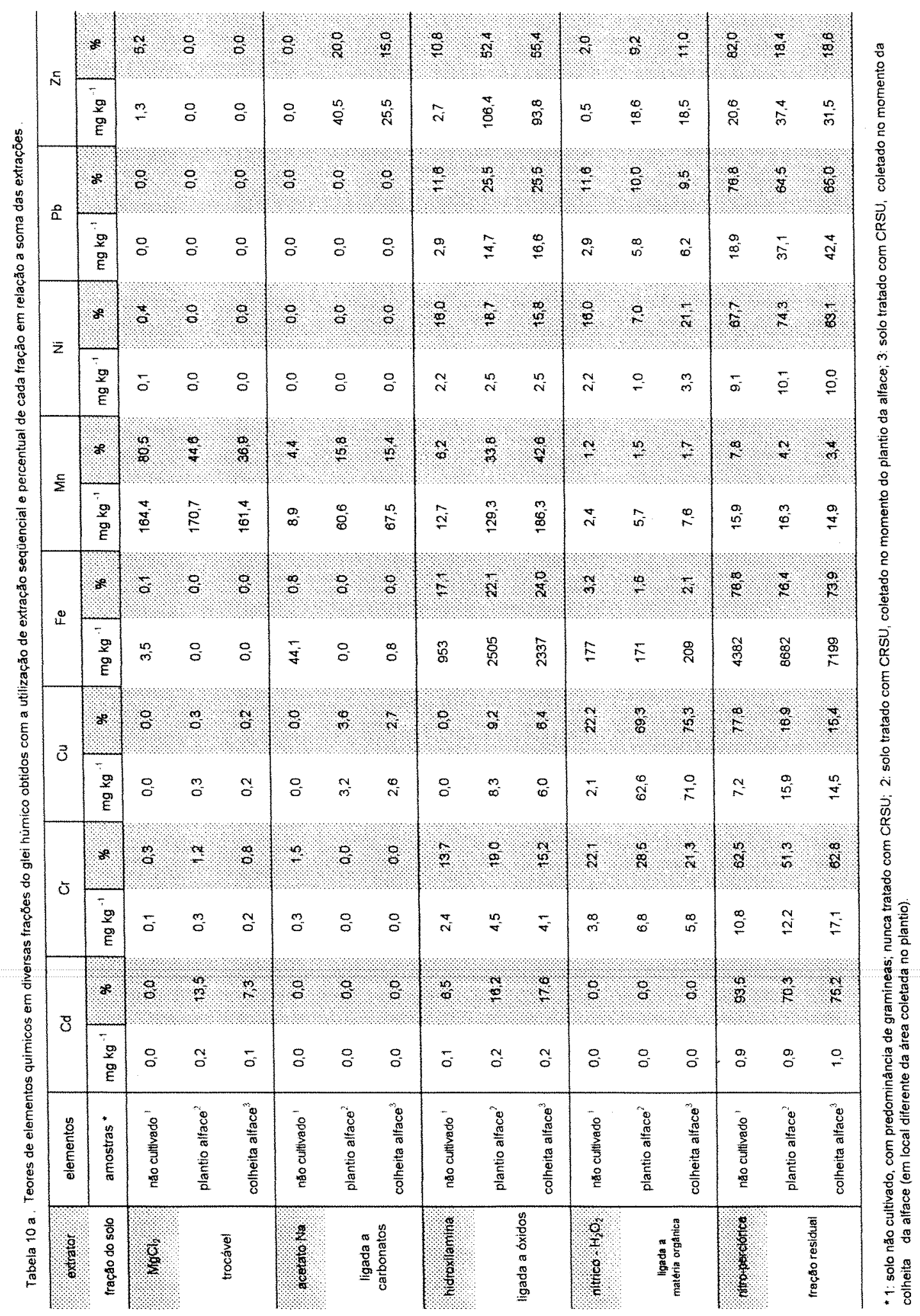


Nas amostras coletadas nas áreas não cultivadas dos dois solos pode-se observar que os elementos avaliados ( $\mathrm{Cd}, \mathrm{Cr}, \mathrm{Cu}, \mathrm{Fe}, \mathrm{Mn}, \mathrm{Ni}, \mathrm{Pb}$, $\mathrm{Zn}$ ) se encontravam principalmente na fração residual, com exceção do $\mathrm{Pb}$ no podzólico vermelho-amarelo e do Mn para os dois solos.

Quanto ao efeito da aplicação do CRSU na distribuição dos elementos nas frações do solo, no caso do $\mathrm{Cd}$, diferentemente de outros trabalhos (Bell et al., 1991; Gomes, 1996; Gomes et al., 1997), o Cd teve pouca participação nas frações que podem ser consideradas mais disponiveis. Nas áreas não cultivadas praticamente todo o $\mathrm{Cd}$ foi encontrado na fração residual $(93 \%)$, com um pequeno percentual na fração ligada a óxidos (7\%). Nos solos tratados com CRSU houve uma distribuição do elemento, que se apresentou ainda principalmente na fração residual (glei $73 \%$ e podzólico $82 \%$ ), ocorrendo também na fração ligada a óxidos (15\%) e na fração trocável (cerca de $10 \%$ no glei e $5 \%$ no podzólico).

Parkpain et al. (1998) e Martin \& Kaplan (1998) verificaram que a diminuição da disponibilidade do $\mathrm{Cd}$ em campos cultivados ao longo do tempo se deveu a migração para formas químicas menos acessiveis às plantas e não a lixiviação. Brams \& Anthony (1988) observaram que $81 \%$ do $\mathrm{Cd}$ tornou-se não disponivel após seis anos de sua incorporação ao solo enquanto que Hamon et al. (1998), utilizando técnicas de diluição isotópica, puderam verificar que, em áreas que receberam aplicação de superfosfato simples desde 1948, de 1 a $1,5 \%$ do teor de $\mathrm{Cd}$ total é imobilizado por ano, o que pode implicar numa significante estratégia de exclusão do elemento das reações de equilíbrio entre a solução e a fase sólida do solo, determinando a diminuição da fração biodisponivel.

$\mathrm{O} \mathrm{pH}$ pode ser considerado um limitante para a presença do $\mathrm{Cd}$ nas formas mais disponiveis (Chang et al., 1982; Valdares et al., 1983; He \& Singh, $1993_{a, b}$ ), mas, no presente trabalho, o elemento não foi detectado nestas frações, tanto para as áreas cultivadas $(\mathrm{pH} \mathrm{6,5)}$ quanto nas áreas não cultivadas $(\mathrm{pH} 4,0)$ (tabelas 6 e 10). 
A presença do $\mathrm{Cd}$ associado à fração oxídica como segunda principal superfície adsorvente após a fração residual sugere que a presença de óxidos possa limitar a presença do elemento em frações mais disponíveis.

A forma na qual o Cd permanecerá ao longo do tempo não pode ser esclarecida com a definição de apenas uma variável. Além do pH, outros fatores como presença de diferentes superfícies adsorventes, taxa de aplicação do elemento, tempo e intensidade de contato entre o elemento e as partículas do solo e taxa de reconversão devem ser considerados (Uren, 1992; Mann \& Ritchie, 1993, Mann \& Ritchie, 1994; McLaren et al., 1998).

A distribuição do $\mathrm{Cr}$ nas áreas tratadas com CRSU foi semelhante à encontrada nas áreas não cultivadas para os dois solos, predominando na fração residual $(65 \%)$ e também presente na fração ligada a óxidos (17\%) e fração ligada a matéria orgânica (glei $24 \%$ e podzólico 15\%) (Tabelas 10). Echeverría et al., 1999, utilizando também o método de fracionamento de Tessier (1979), verificaram em diversos solos que $80 \% \mathrm{do} \mathrm{Cr}$ estava ligado a frações não trocáveis. Estes autores sugerem que a presença de outros cátions, tais como $\circ \mathrm{Cd}, \circ \mathrm{Ni}, \circ \mathrm{Zn}$ e principalmente $\circ \mathrm{Cu}$, contribuem para uma maior adsorção do $\mathrm{Cr}$.

Enquanto que nas áreas não cultivadas o $\mathrm{Cu}$ predominou na fração residual (80\%), nas áreas tratadas com CRSU o elemento apresentou-se distribuído nas frações: ligada a matéria orgânica (glei $72 \%$ e podzólico 51\%), fração residual (glei 16\% e podzólico $31 \%$ ) e ligada a óxidos (glei $8 \%$ e podzólico 14\%) (Tabelas 10a e 10b). As desigualdades de distribuição do $\mathrm{Cu}$ nas áreas tratadas com CRSU dos dois solos podem ser atribuídas às diferenças de quantidade e qualidade da fração argila e da matéria orgânica.

O podzólico possui um teor de argila (69\% - tabela $3 \mathrm{e}$ ) maior do que o glei húmico ( $46 \%$ - tabela $2 e$ ). Os dois solos também são muito diferentes com relação à qualidade da fração argila, que no podzólico apresenta $66,5 \%$ de gibbsita e $32,1 \%$ de caulinita (tabela $3 c$ ) enquanto que no glei húmico $19,0 \%$ de gibbsita e $68,5 \%$ de caulinita (tabela $2 c$ ). 
A quantidade de matéria orgânica nas áreas tratadas com CRSU é maior no glei húmico $\left(90 \mathrm{~g} \mathrm{dm}^{-3}\right)$ do que no podzólico $\left(55 \mathrm{~g} \mathrm{dm}^{-3}\right)$ e, observados os teores das áreas não cultivadas nos dois solos (glei $106 \mathrm{~g} \mathrm{dm}^{-3} \mathrm{e}$ podzólico $44 \mathrm{~g} \mathrm{dm}^{-3}$ ), espera-se que a fração orgânica do glei húmico seja mais estabilizada (tabela 6).

McLaren \& Crawford $\left(1973_{a, b}\right)$ encontraram em diversos solos uma forte correlação entre os teores de $\mathrm{Cu}$ associados a fração residual e 0 percentual de argila da textura destes solos, atribuindo o fato à eficiência parcial dos extratores das frações orgânica e ligada a óxidos.

Face a sua afinidade pela matéria orgânica o $\mathrm{Cu}$ estaria sujeito aos efeitos da hipótese da "bomba relógio química", ou seja, um aumento da disponibilidade após a degradação da matéria orgânica. No entanto, a literatura mostra que a velocidade do processo se torna bastante lenta após a decomposição de cerca de 20 a $40 \%$ da matéria orgânica nos primeiros 12 a 18 meses, podendo esta fração residual ter uma meia vida de varias centenas de anos (McBride \& Blasiak, 1979; Shuman, 1979; Schalscha et al., 1982; Coker \& Matthews, 1983; Miller et al., 1986a,b; Schalscha et al., 1999; Wu et al., 1999).

O Fe predominou na fração residual nas áreas tratadas dos dois solos (glei $75 \%$ e podzólico $94 \%$ ), aparecendo também na fração ligada a óxidos (glei $23 \%$ e podzólico $6 \%$ ), da mesma forma que nas áreas não cultivadas (tabela 10).

Diferentemente dos outros elementos, o Mn nas áreas não cultivadas predominou na fração trocável nos dois solos (83\%) o que pode ser atribuido ao menor valor de $\mathrm{pH}$ destas áreas $(4,0)$ em relação ao das áreas cultivadas $(6,5)$.

Nas áreas tratadas com CRSU o Mn distribui-se principalmente nas seguintes frações: trocável (glei $40 \%$ e podzólico $49 \%$ ), ligada a carbonatos (glei $16 \%$ e podzólico $23 \%$ ) e ligada a óxidos (glei 38 \% e podzólico $21 \%$ ). Pode-se verificar a predominância do $\mathrm{Mn}$ nas frações mais disponíveis, o que pode limitar a absorção de outros microelementos. (Chaney et al., 1994). 
A adsorção do Ni pode ser afetada por fatores como a presença de óxidos, o teor de matéria orgânica do solo e o pH (Camargo et al., 1989). Nas amostras avaliadas no presente estudo a interação entre estes fatores pode ter refletido na pouca ou nenhuma alteração na distribuição relativa para as diferentes frações quando comparadas as áreas tratadas e não tratadas com CRSU dos dois solos.

No caso do $\mathrm{Pb}$, enquanto na área não cultivada do glei húmico houve predominância da fração residual $(77 \%)$, no podzólico vermelho-amarelo - elemento nesta fração esteve abaixo do limite de detecção. Os valores observados nas outras frações sugerem a ocorrência de problemas de determinação analítica, o que não é incomum no caso deste elemento (Chaney \& Ryan, 1993).

No CRSU utilizado predominam as formas de $\mathrm{Pb}$ ligadas a fração ligada a matéria orgânica (50\%), ligada a óxidos (20\%) e residual $(20 \%)$, não havendo migração entre as frações em função do tempo de maturação (Marchiori et al., 1998). Já nos solos tratados com composto, a distribuição do $\mathrm{Pb}$ predominou na fração residual (glei $65 \%$ e podzólico $57 \%$ ), ocorrendo também na fração ligada a óxidos (glei $26 \%$ e podzólico $37 \%$ ) e na fração ligada à matéria orgânica (cerca de 10\%).

Principalmente para o podzólico vermelho-amarelo, pode-se notar a afinidade do $\mathrm{Pb}$ com os óxidos. Elliott et al. (1986) afirmam que em alguns solos a adsorção competitiva do $\mathrm{Pb}$ por sítios inorgânicos pode superar a adsorção pelos sítios orgânicos. Este comportamento sugere que, na ausência da matéria orgânica ou ainda, com a biodegradação da mesma, outros sitios podem vir a limitar a biodisponibilidade dos microelementos, em especial do Pb (Eick et al., 1999; Wu et al. 1999). Mattiazo-Prezotto (1994) propôs a utilização dos teores de óxidos e de argila como parâmetros para a aplicação de biossólidos em solos agrícolas o que também pode ser válido para a aplicação de CRSU. 
Para inferir sobre disponibilidade da fração de microelementos ligados a óxidos ao longo do tempo um melhor detalhamento do fracionamento desta seria necessário. A adsorção do $\mathrm{Pb}$ pelos óxidos de $\mathrm{Mn}$, por exemplo, chega a ser quarenta vezes mais intensa do que a que ocorre através dos óxidos de Fe (McKenzie, 1980).

Da mesma forma que para os óxidos, a fração orgânica necessitaria de uma melhor discriminação para um melhor entendimento dos diferentes graus de intensidade da associação do $\mathrm{Cu}$ com este componente (Temminghoff et al., 1997; Wu et al., 1999).

Para o $\mathrm{Zn}$, nas áreas não cultivadas houve predominância da fração residual nos dois solos (glei $82 \%$ e podzólico $64 \%$ ) enquanto que nas áreas tratadas com CRSU o elemento distribui-se em diversas frações, predominando na ligada a óxidos (glei $54 \%$ e podzólico $60 \%$ ) mas também ocorrendo na fração residual $(18 \%)$ e ligada a carbonatos $(17 \%)$. No caso do presente estudo a presença do $\mathrm{Zn}$ associado à matéria orgânica foi baixa mas a presença do elemento nesta fração pode ser elevada para solos arenosos (Shuman, 1999a).

Luo \& Christie (1998) e Schalscha et al. (1999), trabalhando também com o método de Tessier (1979) modificado encontraram resultados para a distribuição do $\mathrm{Zn}$ semelhantes aos do presente estudo.

A ocorrência de teores elevados de zinco associado a carbonatos nas amostras das área tratadas com CRSU sugere que a manutenção do pH em torno dos teores encontrados, em média 6,5, (tabela 6), possa ser importante para que não ocorra fitotoxicidade causada por este elemento. Estudando a migração de metais para as diversas formas químicas provocada pelo uso de biossólidos, $\mathrm{Li}$ et al. (1997) verificaram que praticamente todo o $\mathrm{Zn}$ ligado a fração orgânica migrou para a fração ligada a carbonatos e para a fração residual quando os biossólidos foram adicionados a um Mollisol com $\mathrm{pH}$ igual a 6,2 enquanto que, quando adicionados a um Ultisol ácido $(\mathrm{pH} 4,5) \circ \mathrm{Zn}$ migrou para a fração ligado a carbonatos e para a fração trocável, 
evidenciando a importância do pH para o comportamento do $\mathrm{Zn}$, o que também foi verificado por Neilsen et al. (1986) e Sims \& Kline (1991).

$\mathrm{O}$ efeito do $\mathrm{pH}$ sobre o comportamento $\mathrm{Zn}$ é mais marcante do que sobre outros microelementos como $\mathrm{Pb}, \mathrm{Ni}$ e $\mathrm{Cu}$ (Harter, 1983). Além do $\mathrm{pH}$, a migração do $\mathrm{Zn}$ para diferentes frações no solo depende de fatores como pe, CTC, temperatura, tempo de contato, presença de fosfatos e de óxidos de Fe, Mn e Al (Bolland et al., 1977; McBride \& Blasiak, 1979; Brümmer et al., 1983; Barrow, 1986 a,b,c; Machado \& Pavan, 1987; Shuman, 1988; Xian \& Shokohifard, 1989; Barrow, 1993; Cunha et al., 1994a,b; Chowdhury et al., 1997; Zhang et al., 1997 Barrow \& Whelan, 1998; Nyamangara, 1998).

De forma geral, o efeito da adição de matéria orgânica sobre os microelementos potencialmente tóxicos pode ser variado, dependo de suas caracteristicas.

Segundo Shuman, 1998 e Shuman, 1999b a aplicação de materiais capazes de formar complexos orgânicos solúveis como, por exemplo, a cama de frango, podem promover uma maior disponibilidade do $\mathrm{Cd}$ e do $\mathrm{Pb}$, enquanto que materiais mais humificados podem promover a migração de microelementos de formas trocáveis e ligadas a matéria orgânica para frações menos disponíveis.

Nas áreas avaliadas no presente trabalho, de forma geral, a aplicação de CRSU associada ao uso intenso de fertilizantes e calcário (tabela 6), para a maioria dos elementos fez com que houvesse predomínio das frações menos disponiveis.

Destacando-se os dois elementos que tiveram maior incremento nos teores totais: o $\mathrm{Cu}$ e $\circ \mathrm{Zn}$ (tabela 7), enquanto que nas áreas não cultivadas estes elementos predominam na fração residual, nas áreas tratadas o Cu passou a predominar na fração ligada a matéria orgânica e o $\mathrm{Zn}$ passou a predominar na fração ligada a óxidos (tabela 10). 


\subsection{Plantas}

\subsubsection{Teores de microelementos nas folhas de alface}

Os teores dos microelementos nas folhas de alface coletadas na primeira etapa (fevereiro e março) são apresentados na tabela 11 e os das folhas das plantas coletadas na segunda etapa (setembro) na tabela 12.

Quanto à fitotoxicidade verifica-se que, com exceção do $\mathrm{Cr}$ nas amostras coletadas na primeira etapa e do $\mathrm{Cu}$, neste caso, apenas numa das amostras, as plantas absorveram os microelementos estudados em quantidades abaixo do limite fitotóxico (tabelas 11 e 12)

Os teores de $B$ observados estiveram bem abaixo dos considerados como fitotóxicos e não diferiram entre as diferentes áreas $(p>0,05)$. A alface é considerada uma espécie semi-tolerante a concentrações mais elevadas de boro (Adriano, 1986).

As concentrações de $\mathrm{Cd}$ verificadas estiveram bem abaixo das consideradas como fitotóxicas e não foram significativamente diferentes $(p>0,05)$ entre as diversas áreas avaliadas (tabelas 11 e 12).

Em experimentos de vasos em casa de vegetação, os teores observados em alface por Amaral et al (1994), trabalhando com corretivos, e por Gomes (1996) e Lehoczky et al. (1998), trabalhando com a adição de sais, foram bastante elevados ( 4 a $58 \mathrm{mg} \mathrm{kg}^{-1}$ ), não tendo sido relatados sintomas de fitotoxicidade. Estes resultados revelam ser o Cd um elemento que apresenta um comportamento de risco pois, pode acumular-se nos tecidos vegetais sem apresentar sintomas de fitotoxicidade em teores acima dos recomendáveis para a nutrição humana. (Cunningham et al., 1975a,b; Chumbley \& Unwin, 1981; Coker \& Matthews, 1983; Tiller, 1989; Cieslinski et al., 1994; Warman et al., 1995; Lagriffoul et al., 1998). 


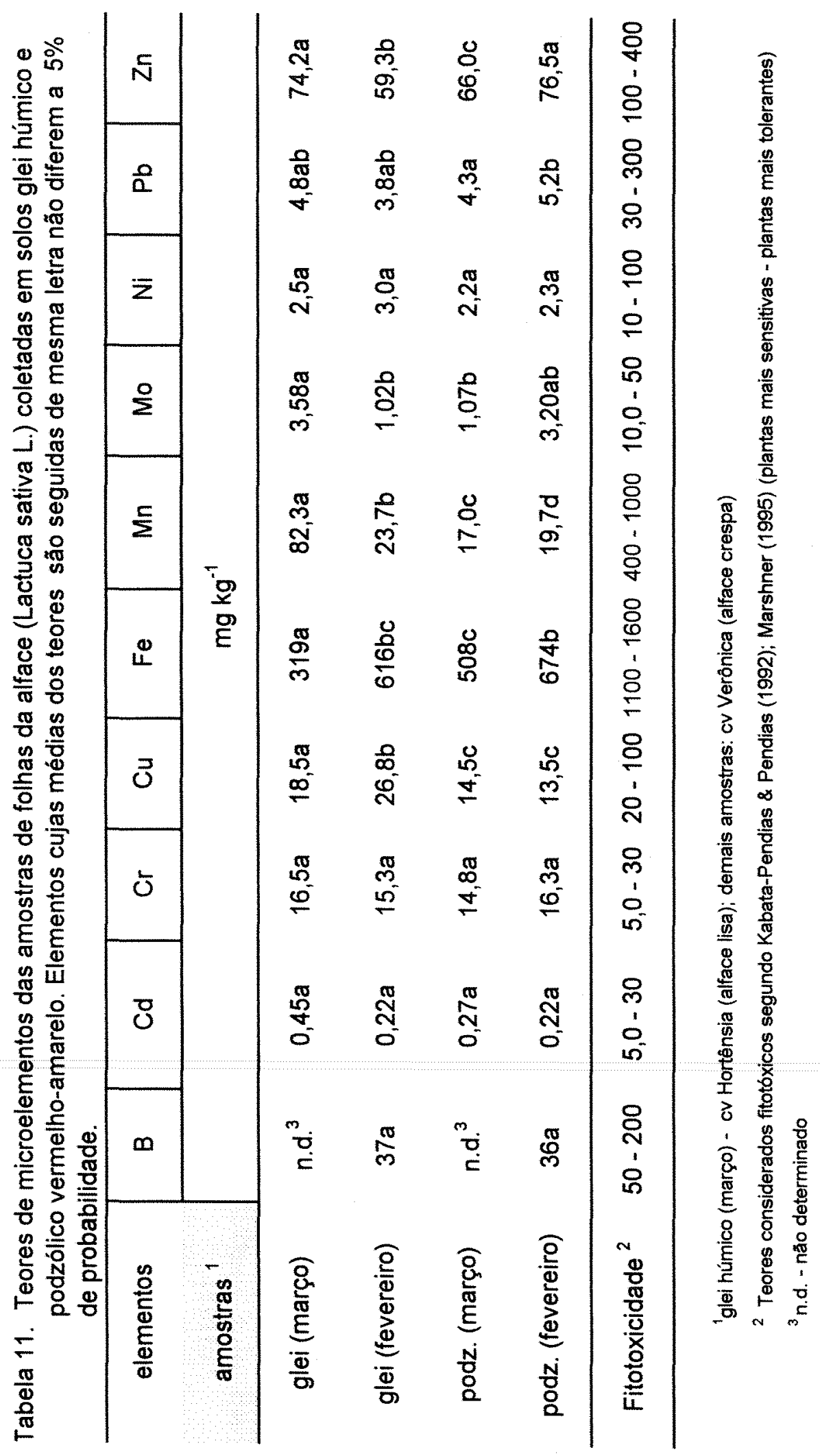




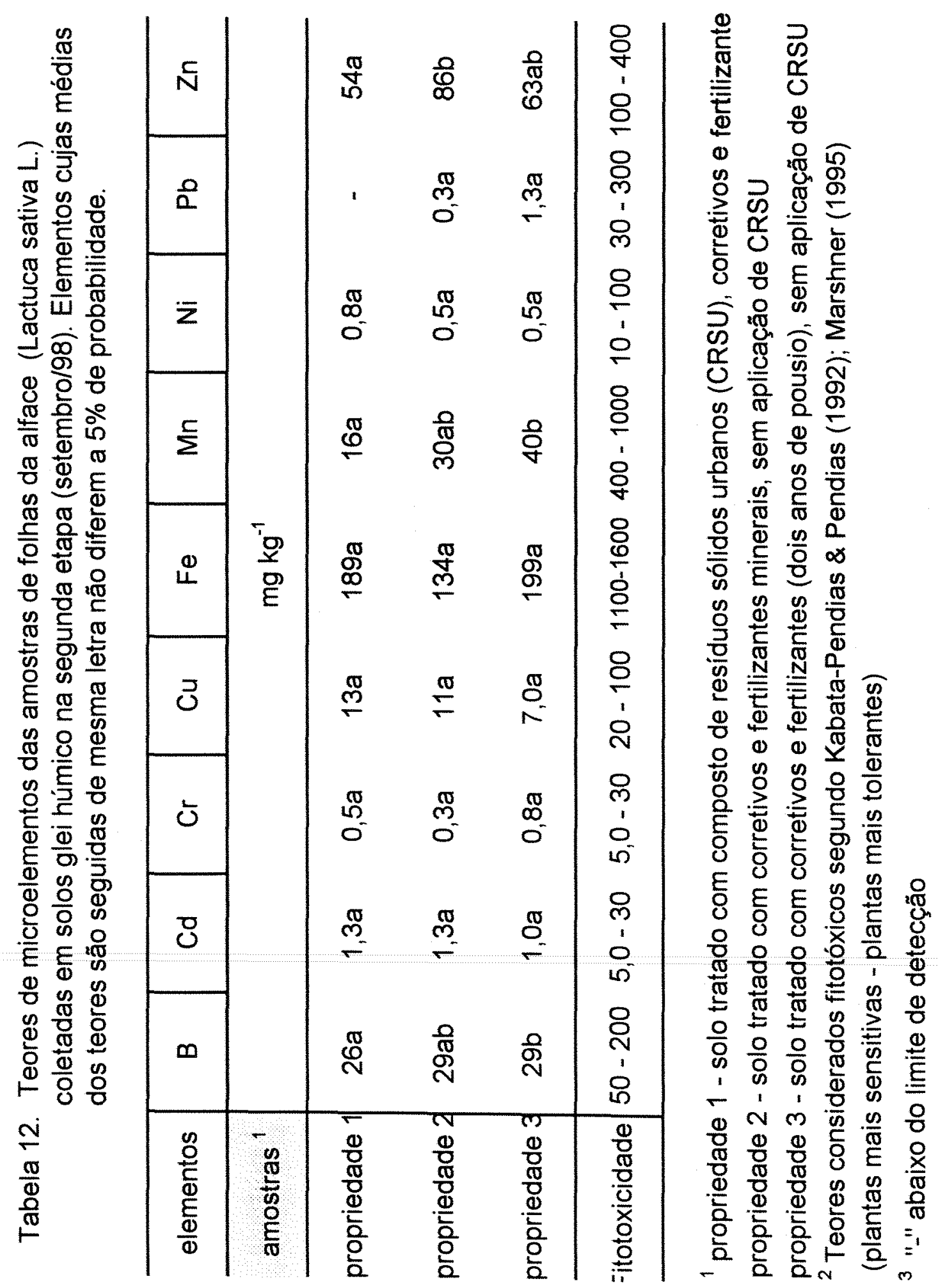


Os teores de $\mathrm{Cd}$ nas folhas de alface observados no presente trabalho em condições de campo, entre 0,22 e $1,3 \mathrm{mg} \mathrm{kg}^{-1}$, são inferiores aos verificados por outros autores em condições de casa de vegetação, corroborando o trabalho de De Vries (1978) que demonstrou estes ensaios superestimam a absorção do $\mathrm{Cd}$ que ocorre em condições de campo, o mesmo ocorrendo quando o elemento é fornecido via sal (Behel et al., 1983; Kuo et al., 1985; Bell et al, 1991; Wilke, 1991; Chaney et al., 1994; EPA, 1995; Candelaria \& Chang, 1997; Brown et al. 1998).

A absorção do Cd no presente estudo pode ter sido limitada pelos teores de $\mathrm{Zn}$ observados. Estes dois elementos pertencem ao grupo II da tabela periódica e possuem muitas similaridades químicas, competindo entre si por vários ligantes. Desta forma, as interações destes elementos nos sistemas biológicos deve ser similar (Das et al., 1997). Quando a relação Zn:Cd é superior a 100, como é o caso do presente trabalho, a absorção do Cd pelas plantas é limitada pelo $\mathrm{Zn}$.

Chaney et al. (1998 ${ }_{\mathrm{a}}$ ) afirmam que o fato da relação $\mathrm{Zn}: \mathrm{Cd}$ em fertilizantes minerais normalmente ser menor do que 100, faz com que através desta fonte o Cd possa estar mais biodisponivel do que através da aplicação de CRSU ou lodo de esgoto. Os valores observados nas amostras do glei húmico coletadas na segunda etapa mostram que não houve diferença significativa $(p>0,05)$ entre a área que utilizou o CRSU (propriedade 1 ) e as áreas que utilizam corretivos e fertilizantes minerais e onde o composto nunca foi aplicado (propriedades 2 e 3 ).

Em ensaios de longa duração conduzidos no campo, com CRSU ou com lodo de esgoto pode-se verificar que a concentração do Cd nas plantas, ou manteve-se constante, ou reduziu ao longo do tempo, quando a concentração do elemento nestes materiais não é muito elevada (menor que $20 \mathrm{mg} \mathrm{kg}^{-1}$ ), como é o caso do CRSU utilizado nas propriedades do presente estudo (Haan, 1981; Corey et al., 1987; Brams \& Anthony, 1988; Chaney, 1990 b; Brown et al., 1998). Deve-se considerar que estas fontes orgânicas 
podem contribuir para o incremento dos teores de $\mathrm{Cd}$ mas, concomitantemente, também favorecem mecanismos que reduzem a sua biodisponibilidade como, por exemplo, a complexação (Maclean, 1976; Lamim et al., 1996; Sterrett et al., 1996; Brown et al., 1997). As fontes orgânicas podem ainda provocar o efeito "diluição", como conseqüência de um maior crescimento das plantas proporcionado pelo composto (Costa, 1994; Costa et al., 1994a,b).

Os teores de $\mathrm{Cr}$ encontrados nas folhas de alface coletadas na primeira etapa, não diferiram entre si $(p>0,05)$ para os dois solos e foram superiores aos teores considerados como fitotóxicos para plantas mais sensiveis. Este fato poderia induzir uma deficiência de Fe (Adriano, 1986), o que não foi verificado. Na segunda etapa, os teores observados nas plantas cultivadas nas áreas tratadas com CRSU (propriedade 1) não diferiram das plantas cultivadas em áreas que nunca receberam aplicação de composto $(p>0,05)$. Os teores observados nas folhas de alface desta etapa foram bem inferiores aos considerados como fitotóxicos (Kabata-Pendias \& Pendias, 1992).

A grande diferença entre os teores de $\mathrm{Cr}$ nas plantas de alface coletadas no glei húmico na primeira etapa e os observados nas plantas coletadas na segunda etapa na propriedade 1 poderia ser atribuída a variações espaciais, uma vez que os canteiros de coleta de plantas não foram os mesmos. Os teores de $\mathrm{Cr}$ observados nos canteiros da propriedade 1 na primeira etapa foram, em média, $33 \mathrm{mg} \mathrm{kg}^{-1}$, enquanto que nos da segunda etapa, $18 \mathrm{mg} \mathrm{kg}^{-1}$.

Além dos teores no solo, outros fatores que podem influir na absorção de microelementos são o pH, a salinidade, o comprimento do dia na estação de crescimento, temperatura e intensidade luminosa (Chang et al., 1987; Xue \& Harrison, 1991). Estes aspectos sugerem que a escolha da época de coleta possa ser importante na determinação dos teores de microelementos em plantas.

A temperatura média da estação de crescimento das amostras coletadas no glei húmico na primeira etapa foi estimada em $23^{\circ} \mathrm{C}$ e a das 
amostras coletadas na segunda etapa cerca de $18^{\circ} \mathrm{C}$ (tabela 1). Com exceção do $\mathrm{Cd}$, todos os elementos determinados nas duas etapas apresentaram menor absorção na época mais fria. $\mathrm{O} \mathrm{Cr}$ foi o elemento que apresentou diferenças mais notáveis de teores nas folhas de alface entre as duas épocas de coleta de amostras (fevereiro/março e setembro), o que também poderia ser atribuído a problemas analíticos.

No caso do $\mathrm{Cu}$, na primeira etapa os teores observados nas folhas de alface do glei húmico foram significativamente maiores do que os do podzólico vermelho-amarelo. As plantas coletadas no glei em fevereiro (cv Verônica, alface crespa) apresentaram teores significativamente superiores $(p<0,05)$ aos das plantas coletadas em março ( $c v$. Hortênsia, alface lisa), o que pode ter ocorrido devido à diferente capacidade de absorção das variedades (Santos, 1995). Tanto alface quanto a beterraba são consideradas tolerantes a elevadas concentrações de Cu (Adriano, 1986), todavia, teores de $\mathrm{Cu}$ da ordem de $20 \mathrm{mg} \mathrm{kg}^{-1}$ em alface foram correlacionados com redução na produção por Nakagawa et al. (1993). Com exceção do teor de Cu de uma das áreas (glei húmico com coleta em fevereiro $-26,8 \mathrm{mg} \mathrm{kg}^{-1}$ ), todas as demais amostras estariam apresentando teores abaixo do limite considerado fitotóxico (tabelas 12 e 13).

Na segunda etapa de coleta (setembro), a aplicação do CRSU não provocou maior acúmulo de $\mathrm{Cu}$ nas folhas de alface colhidas da propriedade 1 , em relação às propriedades 2 e 3 onde o composto nunca foi aplicado $(p>0,05)$ e, os teores observados (de 7 a $13 \mathrm{mg} \mathrm{kg}^{-1}$ ), estiveram abaixo do limite considerado fitotóxico para as plantas mais sensiveis (20 $\mathrm{mg} \mathrm{kg}^{-1}$ - tabela 12).

Os teores de $\mathrm{Fe}$ e $\mathrm{Mn}$ estiveram bem abaixo dos limites considerados como fitotóxicos. O mesmo ocorreu para o $\mathrm{Mo}, \mathrm{Ni}$ e $\mathrm{Pb}$ sendo que, no caso destes elementos, com exceção dos teores de Mo na cultivar hortênsia (glei húmico, amostras coletadas em março), não foram observadas diferenças significativas entre as áreas $(p>0,05)$. O conhecimento dos teores 
de $\mathrm{Fe}$ é interessante para eventualmente verificar o efeito antagônico de outros microelementos como o $\mathrm{Zn}, \mathrm{Cu}$ e $\circ \mathrm{Ni}$, que podem induzir a uma deficiência de Fe. O mesmo raciocínio vale para a interação $\mathrm{Cu}-\mathrm{Mo}$. (Brown \& Jones, 1975; Coker \& Matthews, 1983; Gupta \& Lipsett, 1981; Poulik, 1999; Vyskocil \& Viau, 1999).

Com relação à absorção de $\mathrm{Pb}$ pela alface, a literatura apresenta resultados superiores aos obtidos neste trabalho. As diferenças de procedimento residem em que tais trabalhos foram realizados em condições de casa de vegetação, sendo a fonte de $\mathrm{Pb}$ em alguns casos, sais minerais e, em outros, CRSU (Costa, 1994; Santos, 1995; Gomes, 1996).

Embora haja dificuldade de comparação dos resultados pelo fato das variedades avaliadas no presente estudo (cv Verônica e cv Hortênsia) serem diferentes das utilizadas pelos autores citados, os teores observados sugerem que a absorção do $\mathrm{Pb}$ presente em CRSU em condições de campo seja menor do que aplicações do elemento via sal ou quando o ensaio é conduzido em vaso, em condições de casa de vegetação. As diferenças que ocorrem entre as duas situaçōes parecem não ser tão marcantes quanto as que ocorrem no caso do $\mathrm{Cd}$. Todavia, cabe salientar que em condições de campo a absorção do $\mathrm{Pb}$ pode apresentar grande variabilidade. Além disto, dos elementos estudados $\circ \mathrm{Pb}$ é um dos mais sujeitos a problemas de determinação analítica (Chaney \& Ryan, 1993). Chumbley \& Unwin (1981) e Logan et al. (1997) observaram teores em folhas de alface entre 0,15 a $10 \mathrm{mg} \mathrm{kg}^{-1}$, não correlacionados com os teores dos tratamentos utilizados. No presente estudo, $\mathrm{Pb}$ nas folhas de alface variou de teores abaixo dos limites detectáveis a $5,2 \mathrm{mg} \mathrm{kg}^{-1}$.

$\mathrm{O} \mathrm{Pb}$ pode atingir teores perigosos para seres humanos sem que nenhum sintoma evidente seja observado nas plantas (Tiller, 1989; Wierzbicka, 1999). Boon \& Soltanpour (1992) verificaram que as folhas de plantas de alface cultivadas em solo contaminado atingiram teores de $\mathrm{Pb}$ de até $45 \mathrm{mg} \mathrm{kg}^{-1}$ sem que nenhum sintoma de toxicidade fosse detectado. 
A preocupação com os riscos para a cadeia trófica que os microelementos potencialmente tóxicos presentes em resíduos orgânicos urbanos podem causar, no caso do lodo de esgoto tem sido mais voltada para o $\mathrm{Cd}$, um reflexo dos resultados de ensaios conduzidos em condições controladas, que superestimam mais a absorção do $\mathrm{Cd}$ do que a do $\mathrm{Pb}$, quando comparados com absorção de plantas em condições de campo.

Um aspecto importante a ser enfatizado, para diferenciar os estudos entre lodo de esgoto e CRSU é o fato de que, enquanto a maioria dos microelementos (inclusive o $\mathrm{Cd}$ ), normalmente é maior no lodo de esgoto, no caso do $\mathrm{Pb}$, a concentração normalmente é maior no CRSU (He et al., 1992; He et. al, 1995).

O potencial de fitotoxicidade do $\mathrm{Pb}$ pode ser considerado $\mathrm{O}$ menor dentre os elementos estudados (Adriano, 1986). Matthews (1984) reporta que não houve correspondência entre as concentrações totais no solo e a absorção por 11 tipos de culturas, considerando que mesmo altas concentrações de $\mathrm{Pb}$ podem ser toleradas. Há evidências que os quelatos formados entre a matéria orgânica e $\circ \mathrm{Pb}$ são de baixa solubilidade, o que provoca baixa mobilidade e acúmulo nos horizontes superficiais, além de diminuir a capacidade fisiológica de absorção do elemento pelas plantas (Lund et al., 1976; Lagerweff, 1977; Adriano, 1986; Kabata-Pendias \& Pendias, 1992; Barbarick et al., 1998). A concentração de Fe no CRSU também pode contribuir para reduzir a biodisponibilidade do $\mathrm{Pb}$ (Brown et al., 1997). Os atributos determinados para os dois solos do presente estudo lhes conferem propriedades que devem limitar a mobilidade do $\mathrm{Pb}$ e também a sua absorção.

O Zn também apresentou teores bem abaixo dos considerados fitotóxicos para as culturas mais sensíveis $\left(100 \mathrm{mg} \mathrm{kg}^{-1}\right)$, apesar dos valores elevados deste elemento encontrados no solo nas áreas tratadas com CRSU ( $Z n_{\text {TOTAL }}$ de 140 a $180 \mathrm{mg} \mathrm{kg}^{-1}$ e $Z n_{\text {DTPA }}=40 \mathrm{mg} \mathrm{kg}^{-1}$ ). 
Nas amostras coletadas na segunda etapa (tabela 12), pode-se observar que os teores do $\mathrm{Zn}$ na propriedade 2, que nunca recebeu aplicação de CRSU e com uso mais intenso de fertilizantes minerais (tabela 6), apresentou teores de $\mathrm{Zn}$ significativamente superiores $(p<0,05)$.

O Zn é considerado um dos microelementos de melhor previsibilidade quanto aos teores absorviveis, sendo que o extrator DTPA tem uma boa correlação com a absorção de zinco pela alface $(0,88)$ e também com a beterraba $(r=0,94)$ (Xiu et al., 1991; King, 1996). No entanto, os teores de Zn efetivamente absorvidos podem variar em função da variedade considerada, particularmente em alface (51 a $125 \mathrm{mg} \mathrm{kg}^{-1}$ - Adriano, 1980; Chumbley \& Unwin, 1981). No caso do presente trabalho, a alface cv. Hortênsia cultivada no glei húmico apresentou teores significativamente maiores do que a cv. Verônica $(p<0,05)$ (tabela 11).

\subsubsection{Distribuição dos microelementos nas diversas partes das plantas de alface e beterraba}

As distribuições dos microelementos nas folhas, caules e raízes para as plantas de alface e beterraba é apresentada na tabela 13.

Com exceção das amostras coletadas no glei húmico em março $(\mathrm{Gp})$ houve uma maior concentração de $\mathrm{Cd}$ nas raízes da alface, o que pode ter ocorrido devido ao elemento ser fortemente adsorvido à parede celular da raiz (Cutler \& Rains, 1974). Nas plantas de beterraba isto também ocorreu, mas não houve diferença estatística $(p>0,05)$, provavelmente pela grande variabilidade observada nas determinações (raízes com média $=0,21 \mathrm{mg} \mathrm{kg}^{-1}$ e desvio padrão $=0,23$ ). Em condições de campo podem ser esperadas grandes variações nas concentrações de microelementos absorvidos pelos vegetais (Adriano, 1986). 


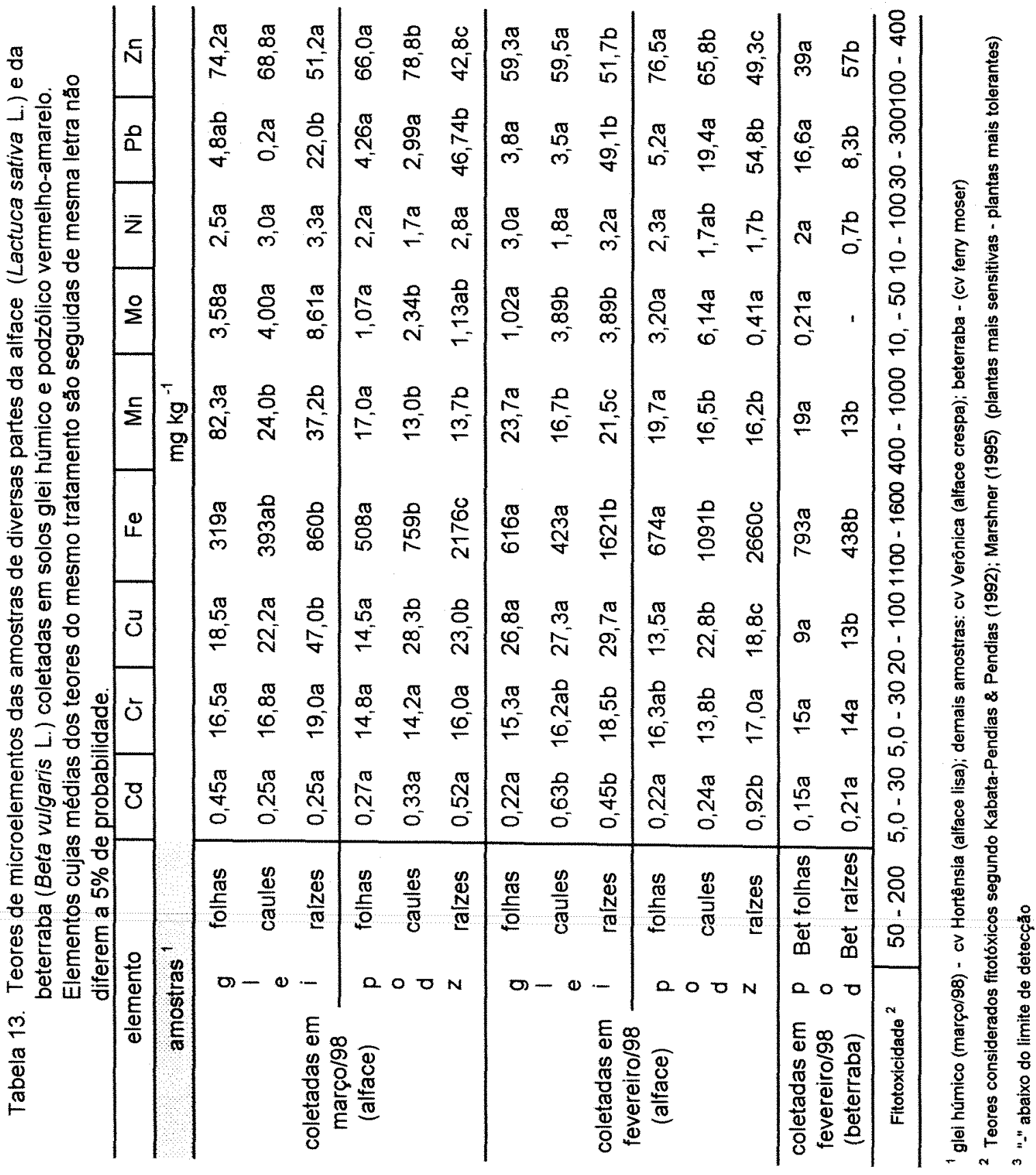


Assim como no presente trabalho, Cravo (1995) e Gomes (1996) também verificaram uma maior concentração de Cd nas raízes da alface enquanto que Costa (1994) verificaram o inverso em plantas de cenoura (Daucus carota L.), sendo o teor nas folhas quatro vezes maior do que nas raizes.

Para o $\mathrm{Cr}$ verifica-se, de forma geral, que houve uma distribuição uniforme nas diversas partes da planta, tanto para a alface quanto para a beterraba $(p>0,05)$. O único caso em que se observou diferença estatística foi para a absorção de $\mathrm{Cr}$ nas amostras de alface, cv Verônica, coletadas em fevereiro no glei húmico (tabela 13)

No caso do $\mathrm{Cu}$, com exceção da alface cv Verônica, nas amostras coletadas em fevereiro no glei húmico, as demais amostras, apresentaram concentração significativamente maior nas raízes $(p<0,05-$ tabela 13) evidenciando a baixa mobilidade deste elemento, conforme também verificado por outros autores (Cravo, 1995; Gomes, 1996).

Para o $\mathrm{Fe}$, na alface os teores do elemento foram significativamente maiores nas raizes $(p<0,05)$ e na beterraba ocorreu 0 inverso enquanto que, o $\mathrm{Mn}$ concentrou-se mais nas folhas da alface e beterraba $(p<0,05)$. Cravo (1995) verificou comportamento semelhante na distribuição do $\mathrm{Fe}$ e do $\mathrm{Mn}$ em plantas de alface.

$\mathrm{O}$ acúmulo de Mo nas diversas partes das plantas de alface apresentou diferenças $(p<0,05)$ nas amostras coletadas no glei húmico em fevereiro e nas coletadas no podzólico vermelho-amarelo em março, onde o elemento concentrou-se mais no caule e nas raizes das plantas, enquanto que para as outras amostras e também para a beterraba não se observaram diferenças $(p>0,05)$ (tabela 13).

$\mathrm{O} \mathrm{Ni}$ apresentou uma distribuição uniforme nas diversas partes da alface $(p>0,05)$, com exceção das amostras coletadas no podzólico vermelho-amarelo em fevereiro, que apresentaram uma maior concentração nas folhas $(p<0,05)$. Na beterraba, o teor deste elemento nas folhas foi 
significativamente superior ao observado nas raizes $(p<0,05)$. O Ni é considerado um microelemento de grande mobilidade nas plantas, normalmente concentrando-se na parte aérea e nos órgãos de reserva, o que pode representar risco para a nutrição humana (Alexander et al., 1978; Sauerbeck, 1991; Sauerbeck \& Hein, 1991; Poulik, 1999). Este comportamento não pode ser detectado para a maioria das amostras de plantas analisadas no presente trabalho.

O Pb predominou nas raizes das plantas de alface $(p<0,05)$ para todas as áreas avaliadas, o que também foi verificado por Cravo (1995) e Gomes (1996). $\mathrm{Na}$ beterraba o $\mathrm{Pb}$ teve comportamento inverso, concentrou-se mais nas folhas $(p<0,05)$.

Dentre os elementos estudados o $\mathrm{Pb}$ é tido como o menos fitotóxico (Adriano, 1986; Sadovnikova \& Zyrin, 1986) mas os teores verificados nas raizes de alface estão acima do limite de fitotoxicidade para espécies mais sensiveis (tabela 13). Teores de $\mathrm{Pb}$ no solo acima de $10 \mathrm{mg} \mathrm{kg}^{-1}$ podem provocar inibição no crescimento das raízes (Obroucheva et al., 1998), mas tal fato não pode ser observado no presente estudo, a despeito de teores elevados do elemento no solo (31 a $120 \mathrm{mg} \mathrm{kg}^{-1}$ - tabela 6).

No caso do $\mathrm{Zn}$ observou-se nas raizes da alface teores significativamente menores do que os das folhas $(p<0,05)$, com exceção das amostras coletadas no glei húmico em março $(p>0,05)$ devido a dispersão dos resultados das diversas repetições, porém, verifica-se que o elemento concentrou-se mais nas folhas (tabela 13). No trabalho de Cravo (1995) observou-se o oposto, o $\mathrm{Zn}$ concentrou-se mais nas raizes do que nas folhas. Nas amostras das plantas de beterraba, o $\mathrm{Zn}$ concentrou-se mais nas raízes $(p<0,05)$, ou seja, comportamento inverso do observado para as plantas de alface (tabela 13).

Os resultados obtidos mostram que a distribuição e acumulação dos microelementos é muito variável, dependendo do elemento e da espécie de planta considerada. Divergências podem ser observadas para plantas da 
mesma espécie crescendo sob diferentes condições ambientais. O comportamento mais comum é a predominância dos microelementos nas raizes (Kabata-Pendias \& Pendias, 1992; King, 1996) mas, conforme pode-se constatar, resultados de plantas cuja parte consumida é a parte aérea não podem ser extrapolados para plantas de raízes comestiveis.

A distribuição dos microelementos nas diversas plantas de alface colhidas no podzólico vermelho-amarelo após 37 dias de crescimento das plantas (no mesmo dia de coleta do glei húmico), e aos 56 dias, quando as plantas atingiram $\circ$ ponto de colheita para comercialização, pode ser observada na tabela 14.

O elementos que apresentaram variação significativa no teor nas folhas em função do tempo de crescimento foram o $\mathrm{Fe}, \circ \mathrm{Ni}$ e $\circ \mathrm{Zn}$ $(p<0,05)$, o que pode ter sido conseqüência de um maior período de absorção ou reflexo de uma absorção tardia significativa deste elemento, conforme também observado por Garcia et al. (1982). Os teores de $\mathrm{Cd}$ nas folhas de alface aos 56 dias foram cerca de três vezes os teores observados aos 37 dias mas não houve diferença estatística $(p>0,05)$ provavelmente pela dispersão dos valores obtidos.

\subsubsection{Toxicidade para a espécie humana}

Os teores de microelementos observados nas folhas de alface coletadas na primeira etapa (fevereiro e março) e na segunda (setembro) foram convertidos para base úmida, a fim de compará-los com os limites máximos permitidos em alimentos pela legislação brasileira (BRASIL, 1998) e internacional (FAO, 1998) e podem ser observados nas tabelas 15 e 16.

Os elementos $\mathrm{B}, \mathrm{Fe}$ e $\mathrm{Mn}$, assim como o Mo, são considerados de baixa toxicidade para os seres humanos, de forma que, para os vegetais estudados, o limite de concentração ainda não foi estipulado (FAO, 1998; FAO 1999 ${ }_{a, b, c} ;$ Vyskocil \& Viau, 1999). 


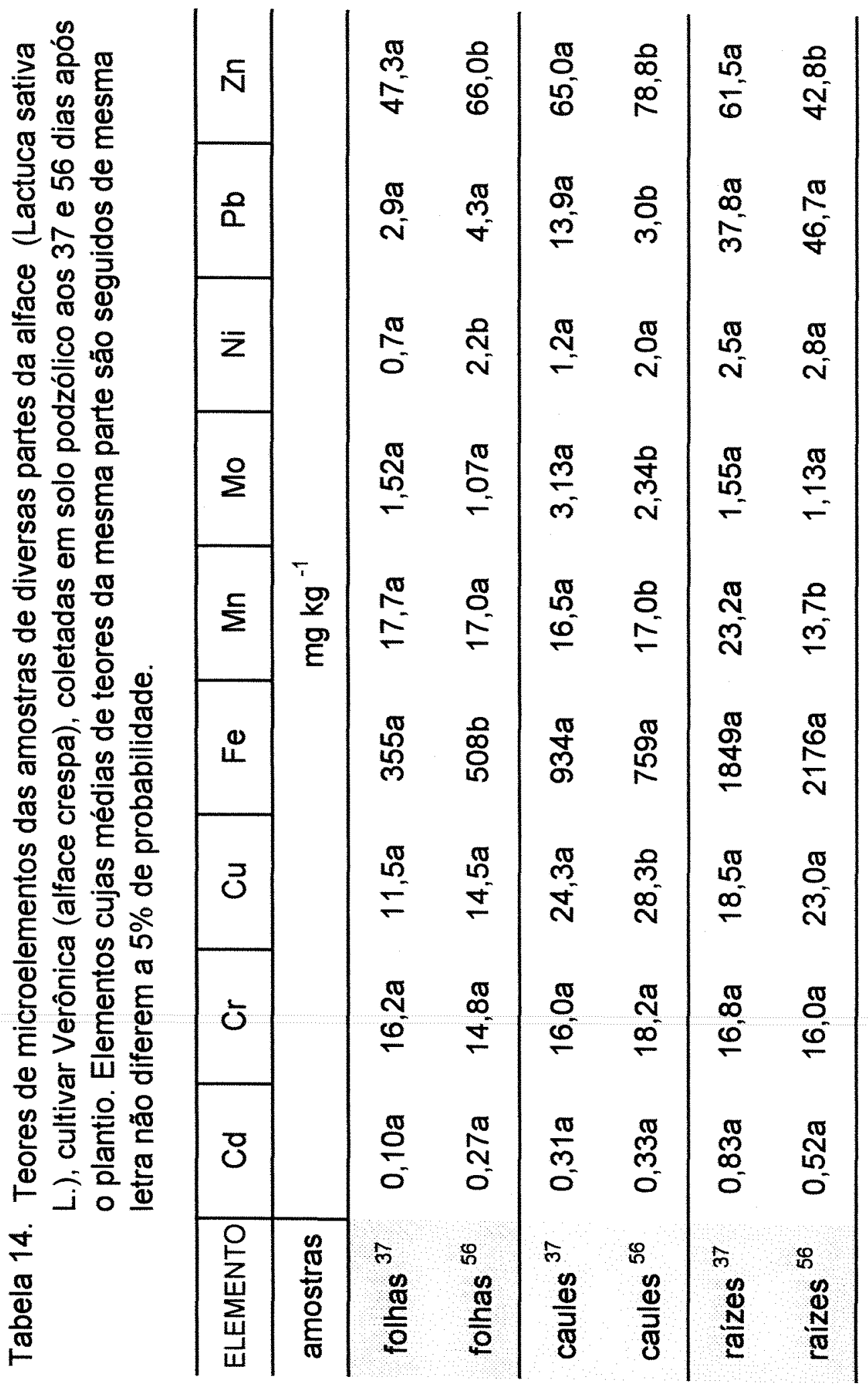




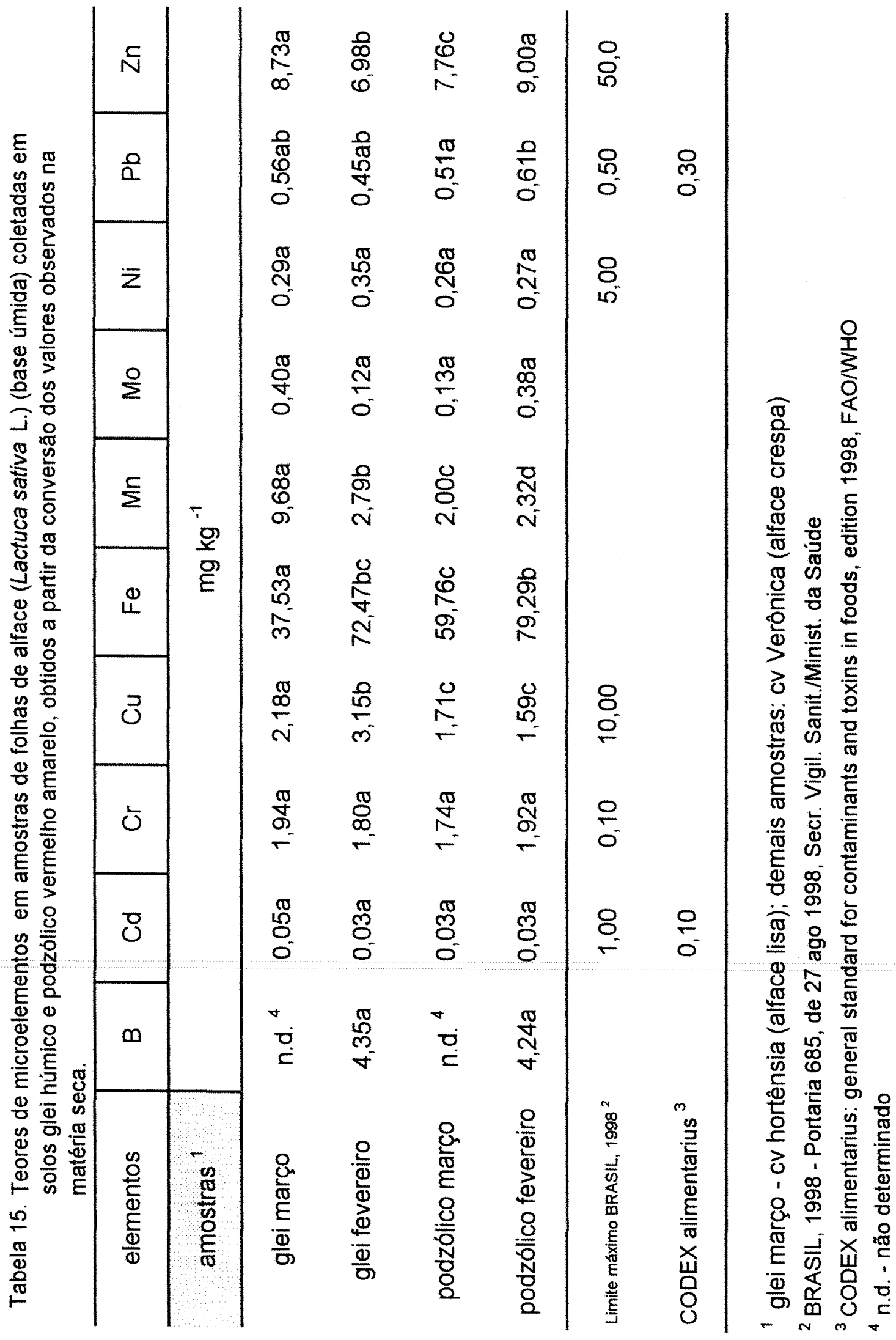




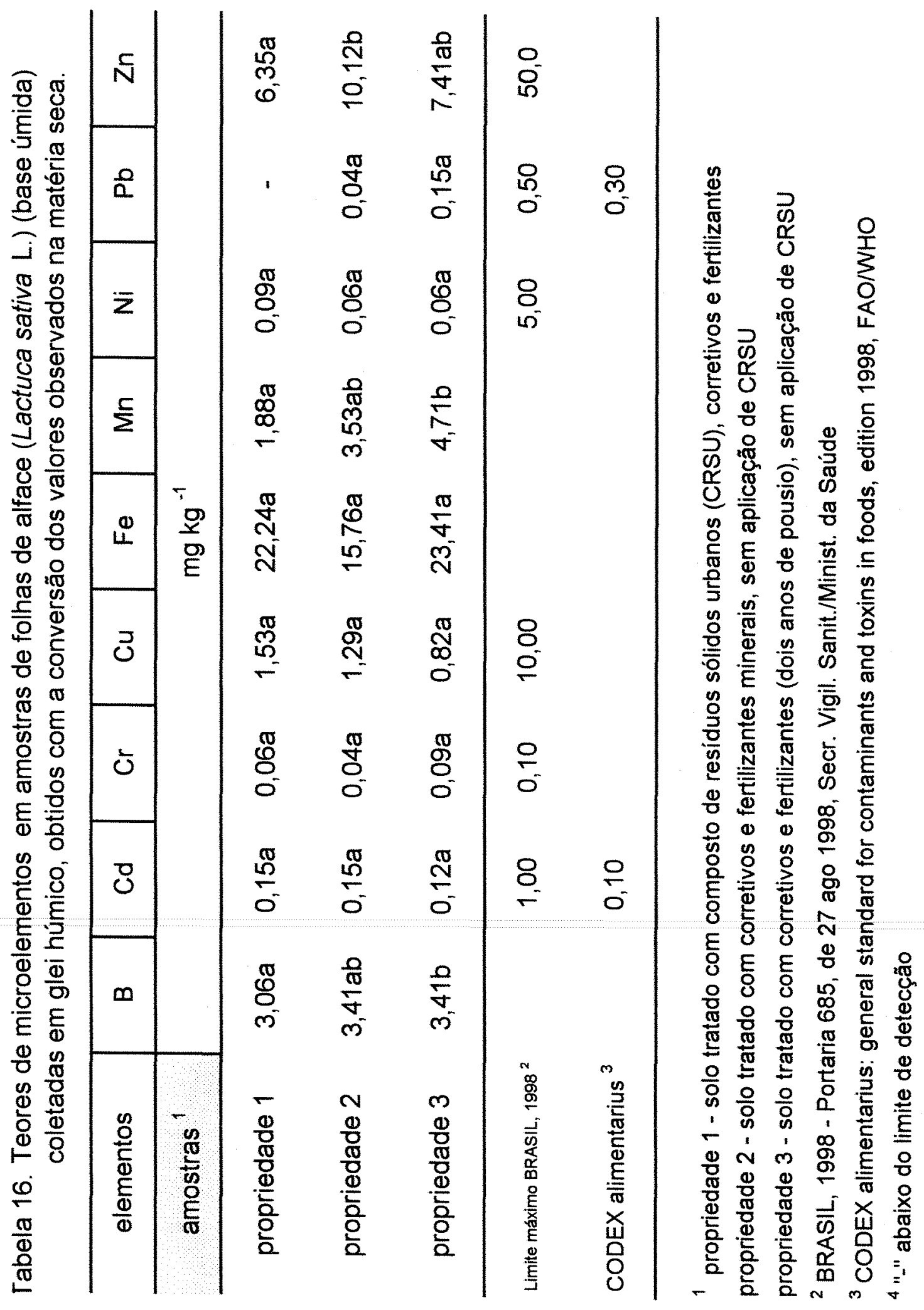


Os teores de $\mathrm{Cd}$ nas folhas de alface coletadas na primeira etapa nos dois solos estão abaixo dos teores admitidos pela legislação brasileira e internacional (BRASIL, 1998; FAO, 1998). Os teores de Cd das folhas de alface coletadas no solo glei na segunda etapa estão abaixo do que é permitido pela legislação brasileira (BRASIL,1998), mas acima do que é permitido pela legislação internacional (FAO, 1998), tanto para as áreas tratadas com composto quanto nas áreas não tratadas (tabelas 15 e 16).

Os teores de $\mathrm{Cr}$ verificados nas amostras coletadas na primeira etapa estão acima do limite estabelecido pela legislação brasileira (BRASIL, 1998), enquanto que os teores de $\mathrm{Cr}$ observados na segunda etapa de coleta estão abaixo deste limite (tabelas 15 e 16).

Os teores de $\mathrm{Cu}, \mathrm{Ni}$ e $\mathrm{Zn}$ nas folhas de alface estiveram abaixo dos valores limites da legislação brasileira (BRASIL, 1998) (tabelas 15 e 16).

No caso do $\mathrm{Pb}$, na primeira etapa, com exceção das plantas coletadas no glei húmico em fevereiro, todas as outras amostras estiveram acima dos teores permitidos pela legislação brasileira e internacional (BRASIL, 1998; FAO, 1998) (tabela 15). Já na segunda etapa de coleta (setembro), todas as amostras apresentaram teores abaixo dos limites admitidos (tabela 16).

Os limites toleráveis de $\mathrm{Pb}$ pela legislação brasileira e internacional têm diminuído ao longo do tempo, provavelmente devido à preocupação com níveis subclinicos de contaminação, ou seja, sintomas não aparentes e à melhoria nos métodos analíticos de determinação (Nehru \& Kaushal, 1992; Pierzynski et al., 1994; Adamis et al., 1999). Em 1990, o Ministério da Saúde revisou os níveis de tolerância para $\mathrm{Pb}$, diminuindo as concentrações aceitáveis na maioria dos alimentos de $8 \mathrm{mg} \mathrm{kg}^{-1}$ para $0,8 \mathrm{mg} \mathrm{kg}^{-1}$ (Brasil, 1990) e o teor de $\mathrm{Pb}$ admissivel pelo Codex alimentarius passou de 2 para 0,3 $\mathrm{mg} \mathrm{kg}^{-1}$ (base úmida) (FAO, 1998; FAO 1999a,b,c).

A fitotoxicidade do $\mathrm{Cd}$ e do $\mathrm{Pb}$ para a alface e para a beterraba é baixa, de forma que estas culturas podem apresentar altos teores destes elementos sem que nenhum sintoma externo seja detectado, o que pode 
representar risco para a nutrição humana (Mahler et al., 1978; Valdares, 1983; Warman et al., 1995; WHO, 1996; Moreno et al., 1997; Chaney, et al., 1998; Lehoczky et al., 1998). Todavia, estas espécies vegetais têm participação limitada na dieta. Segundo o Codex alimentarius (FAO, 1999 $\mathrm{B}$ ) ○ Brasil é classificado como grupo $\mathrm{K}$, onde os cereais participam com $19,1 \%$ da ingestão de $\mathrm{Pb}$, as raízes e tubérculos com $18,7 \%$ e os vegetais participam com apenas $3 \%$.

Os resultados observados no presente trabalho sugerem que que dentre os elementos estudados o elemento que apresenta maior risco para a alimentação humana associado ao uso do composto de resíduos sólidos urbanos é o $\mathrm{Pb}$. O $\mathrm{Cd}$ também apresentou teores acima dos limites permitidos em alimentos nas amostras coletadas na segunda etapa mas a contaminação pode ter sido causada pela utilização de fertilizantes minerais. 


\section{CONCLUSÕES}

Dentre os métodos utilizados na avaliação dos agroecossistemas do presente estudo (micromorfológicos, microbiológicos, físicos e quimicos), os resultados das determinações químicas analíticas foram os que permitiram uma melhor diferenciação entre as áreas tratadas com o composto de residuos sólidos urbanos (CRSU) e as áreas não tratadas.

Nenhum efeito nocivo à microbiota pôde ser detectado com as determinaçōes microbiológicas utilizadas (biomassa e número mais provável de fungos e bactérias), apesar dos teores elevados de Cu extraivel em DTPA em algumas amostras.

A densidade do solo foi pouco afetada pelo uso de CRSU, provavelmente devido ao cultivo intensivo do solo e o incremento no consumo da matéria orgânica do solo provocado por esta prática.

A aplicação do CRSU afetou a condutividade elétrica do solo porém, através das amostras coletadas no glei húmico na segunda etapa, pode-se verificar que o efeito do composto neste parâmetro foi menor do que 0 provocado pelo uso de fertilizantes minerais prontamente solúveis, de maior índice salino relativo.

Verificou-se que a aplicaçāo de CRSU aos solos aumentou a fertilidade, havendo uma elevação do $\mathrm{pH}$, com conseqüente diminuição nos valores de $\mathrm{H}+\mathrm{Al}$ e aumento da CTC e porcentagem de saturação de bases.

Quanto aos teores totais e extraiveis em DTPA dos microelementos nos solos, o $\mathrm{Cu}$ e o $\mathrm{Zn}$ foram os que apresentaram os maiores incrementos nas áreas tratadas com CRSU quando comparadas às áreas não 
cultivadas tomadas como referência nos dois solos, ou às áreas cultivadas adjacentes que nunca receberam aplicação de CRSU no glei húmico, evidenciando que o composto é uma importante fonte destes elementos.

Embora os acréscimos de $\mathrm{Cu}$ e Zn.nas áreas tratadas com composto em relação às áreas tomadas como referência tenham sido elevados (para o Cu, 4,2 vezes no glei e 2,7 vezes no podzólico e para o $\mathrm{Zn} 4,6$ vezes no glei e 6,5 vezes no podzólico), estes teores permaneceram dentro da faixa de valores encontrados em condições naturais para solos do Estado de São Paulo.

Foram observados teores elevados de $\mathrm{Cd}$ e Mo das áreas não cultivadas do podzólico vermelho-amarelo, mais próximas à região metropolitana de São Paulo, e sugere-se a possibilidade de contaminação atmosférica por estes elementos.

A extração seqüencial mostrou que para a maior parte das amostras, os microelementos potencialmente tóxicos encontravam-se na fração residual. Nas áreas tratadas com CRSU, o $\mathrm{Cu}$ apresentou-se mais associado à matéria orgânica e o $\mathrm{Zn}$ mais associado a óxidos. A fração oxídica apresentou também quantidades apreciáveis de $\mathrm{Cu}$ e $\mathrm{Pb}$, notadamente no podzólico vermelho-amarelo, sugerindo que a presença de óxidos possa ser um atributo importante para limitar a biodisponibilidade destes microelementos.

Os teores observados nos tecidos vegetais estiveram abaixo dos teores tidos como fitotóxicos, com exceção do $\mathrm{Cr}$ e do $\mathrm{Cu}$ em algumas amostras, e nenhum sintoma externo foi observado.

Os teores observados nas plantas sugerem que, sob condições de campo, a absorção dos microelementos, de forma geral, é muito variável. No caso do Cd pode-se verificar que os teores nas plantas de alface foram sensivelmente menores do que a absorção deste elemento pela alface observada por outros autores em condições de casa de vegetação e/ou com a aplicação de sais. Além da maior evapotranspiração em condições de casa de vegetação e da maior disponibilidade dos microelementos quando fornecidos 
via sal, outra explicação para tal fato seria a predominância do $\mathrm{Cd}$ nas formas trocáveis nos experimentos de curta duração enquanto que, no presente trabalho, o Cd predominou na fração residual.

A distribuição dos microelementos nas diferentes partes das plantas (raiz, caule e folhas), apresentou grande variabilidade mas, para a maioria dos elementos estudados, foram observados teores mais elevados nas raizes. No caso do $\mathrm{Pb}$, as plantas de alface apresentaram maior concentração nas raízes e na beterraba houve maior concentração nas folhas. Para o Zn a distribuição nas duas espécies também foi diferente, ou seja, na alface ocorreu maior concentração nas folhas e na beterraba nas raízes. As diferenças fisiológicas entre espécies não permite a extrapolação de resultados, principalmente entre plantas cuja parte consumida é a parte aérea e plantas de raízes comestiveis.

Nas plantas de algumas áreas tratadas com CRSU O $\mathrm{Pb}$ foi $\mathrm{O}$ único elemento que apresentou teores acima dos valores permitidos em alimentos e este fato esteve associado à utilização do composto. O Cd também esteve acima do limite permitido em algumas amostras, mas a causa provável de contaminação foi atribuída aos fertilizantes minerais.

De forma geral, os resultados obtidos permitem dizer que, dentre os microelementos avaliados no presente estudo, em locais de cultivo onde se utiliza o composto de residuos sólidos urbanos o principal microlemento a ser monitorado é o $\mathrm{Pb}$. 


\section{REFERÊNCIAS BIBLIOGRÁFICAS}

ABREU, M.F.; BERTON, R.S.; ANDRADE, J.C.; Comparison of methods to evaluate heavy metals in organic wastes. Communications in Soil Science and Plant Analysis, v. 27, n.5/8, p. 1125-1135, 1996.

ADAMS, T.MCM.; SANDERS, J.R. The effect of $\mathrm{pH}$ on the release to solution of zinc, copper and nickel from a metal -loaded sewage sludge. Environmental Pollution. Series B, v. 8, p. 85-99, 1984.

ADAMIS, Z; TÁTRAI, E.; HONMA, K et al. Effects os lead (II) nitrate and a ditriocarbamate fungicide on the rat lung. Journal of Applied Toxicology, v. 19, p. 347-350, 1999.

ADRIANO, D.C. Trace elements in the terrestrial environment. New York: Springer-Verlag, 1986. $533 \mathrm{p}$.

ALBASEL, N; COTTENIE, A. Heavy metals uptake from contamined soils as affected by peat, lime, and chelates. Soil Science Society of America Journal, v. 49, p. 386-390, 1985.

ALBERT, L.A. Curso básico de toxicologia ambiental. México: Centro Panamericano de Ecologia Humana y Salud; Organizacion Panamericana de la Salud; Organizacion Mundial de la Salud; Instituto Nacional Investigaciones sobre Recursos Bióticos. 1985. 371 p.

ALEXANDER, J.; KOSHUT, R.; KEEFER, R. et al. Movement of nickel from sewage sludge into soil, soybeans and voles. In: SYMPOSIUM OF TRACE SUBSTANCE IN ENVIRONMENTAL HEALTH, 12. Columbia, 1978. Proceedings. Columbia: University of Missouri, 1978. p. 377-388.

ALEXANDER, R.; GOLDSTEIN, N. Setting metals standards for fertilizers. Biocycle, v.40, n.5, p.66-69, May 1999.

ALLOWAY, B.J. Heavy metals in soils. London: Blackie Academic \& Professional, 1995. 368 p.

ALLOWAY, B.J.; AYRES, D.C. Chemical principles of environmental pollution. London: Blackie Academic \& Professional, 1997. 395 p.

ALTIERI, M.A. Agroecologia: as bases científicas da agricultura alternativa. Rio de Janeiro: PTAVASE, 1989. $240 \mathrm{p}$.

ALVARES, C.M.B Monitoramento da qualidade das águas subterrâneas (aqüifero Botucatu) e superficiais na regiäo do depósito de resíduos sólidos da cidade de Säo Carlos - SP In: SIMPÓSIO DE CIENCIAS DA ENGENHARIA AMBIENTAL, 2., São Carlos, 1997. Anais. São Carlos: Centro de Recursos Hídricos e Ecologia Aplicada, 1997. p. 141-143.

ALVES, W.L.; MELO, W.J.; FERREIRA, M.E. et al. Efeito do composto de lixo urbano em um solo arenoso e em plantas de sorgo. Revista Brasileira de Ciência do Solo, v. 23, p. 729-736, 1999.

AMARAL, A.S.; DEFELIPO, B.V; COSTA, L.M. Liberação de Zn, Fe, Mn e Cd de quatro corretivos da acidez e absorção por alface em dois solos. Pesquisa Agropecuária Brasileira, v. 29, $n$. 9, p.1351-1358, set. 1994 .

AMARAL SOBRINHO, N.M.B. Fontes de contaminação de solos e qualidade de vida (compact disc). In: CONGRESSO BRASILEIRO DE CIENCIA DO SOLO, 27., Brasília. 1999. Simpósios. Brasilia: SBCS, 1999. 
AMARAL SOBRINHO, N.M.B.; COSTA, L.M.; OLIVEIRA, C. et al. Metais pesados em alguns fertilizantes e corretivos. Revista Brasileira de Ciência do Solo, v. 16, p. 271-276, 1992.

AMARANTE, A. Comportamento geoquimico de metais pesados em sedimentos argilosos da bacia de São Paulo, Suzano-SP. Săo Paulo, 1997. 98 p. Dissertação (Mestrado) - Instituto de Geociências, Universidade de São Paulo.

ANANYEVA, N.D.; DEMKINA, T.S.; JONES, W.J. et al. Microbial biomass in soil of Russia under long-term management practices. Biology and Fertility of Soils, v. 29, p. 291-299, 1999.

ANDERSON, J.M.; INGRAM, J.S.I. Tropical soil biology and fertility: a handbook of methods. Wallingford: $C A B, 1993.221 \mathrm{p}$.

ASHMEAD, H. D. Nutrição \& minerais aminoácidos quelados. São Paulo: Attar Editorial, 1996. 318 p.

AYUSO, M.; HERNÁNDEZ, T; COSTA, F. et al. Influencia del grado de madurez de un residuo urbano sobre la germinacion y disponibilidad de nitrogeno. Suelo y Planta, v.2, n.3, p. 517-527, 1992.

BAATH, E. Effects of heavy metals in soil on microbial processes and populations (A review). Water, Air and Soil Pollution, v. 47, p. 335-379, 1989.

BAKER, A.J.M.; WALKER, P.L. Physiological responses of plants to heavy metals and the quantification of tolerance and toxicity. Chemical Speciation and Bioavailbility, v. 1, p. 7-17, 1989.

BAKER, D.E; SENFT, J.P. Copper. In: ALLOWAY, B.J. Heavy metals in soils. London: Blackie Academic \& Professional, 1995. cap. 8. p. 179-205.

BALFOUR, E.B. The living soil and the Haughley experiment. New York: Universe Books, 1975. 375 p.

BARBARICK, K.A; IPPOLITO, J.A.; WESTFALL, D.G. Extractable trace elements in the soil profile after years of biosolids application. Journal of Environmental Quality, v. 27, p. 801-805, 1998.

BARBARIKA Jr., A; SIKORA, L.J.; COLACICCO, D. Factors affecting the mineralization of nitrogen in sewage sludge applied soils. Journal of Environmental Quality, v. 49, p. 1403-1406, 1985.

BARDGETT, R.D.; MCALISTER, E. The measurement of soil fungal:bacterial biomass ratios as an indicator of ecosystem self-regulation in temperature meadow grasslands. Biology and Fertility of Soils, v. 29 , p.282-290, 1999.

BARDGETT, R.D.; SPEIR, T.W.; ROSS, D.J., YEATES, G.W. Impact of pasture contamination by copper, chromium, and arsenic timber preservative on soil microbial properties and nematodes. Biology and Fertility of Soils. v. 18, p. 71-79, 1994.

BARROW, N.J. Testing a mechanistic model. II. The effects of time and temperature on the reaction of zinc with a soil. The Journal of Soil Science, v. 37, n. 2, p. 277-286, $1986 \mathrm{a}$.

BARROW, N.J. Testing a mechanistic model. IV. Describing the effects of $\mathrm{pH}$ on zinc retention by soils. The Journal of Soil Science, v. 37, n. 2, p. 295-302, $1986 \mathrm{~b}$.

BARROW, N.J. Testing a mechanistic model. VI. Molecular modelling of the effects of $\mathrm{pH}$ on phosphate and on zinc retention by soils. The Journal of Soil Science, v. 37, n. 2, p. 311-318, $1986 \mathrm{c}$.

BARROW, N.J. Mechanisms of reaction of zinc with soil and soil components. In: ROBSON, A.D. Zinc in soils and plants. Dordrecht: Kluwer Academic, 1993. cap. 2, p.15-31.

BARROW, N.J.; WHELAN, B.R. Comparing the effects of $\mathrm{pH}$ on the sorption of metals by soil and by goethite, and on uptake by plants. European Journal of Soil Science, v. 49, p. 683-692, Dec. 1998. 
BATAGLIA, O.C.; FURLANI, P.R.; VALADARES, J.M.A.S. O molibdênio em solos do Estado de São Paulo. In: CONGRESSO BRASILEIRO DE CIENCIA DO SOLO, 15., Viçosa. 1976. Anais. Campinas: SBCS, 1976 . p. 107-111.

BEARE, M.H.; COLEMAN, D.C.; CROSSLEY JR., D.A. et al. A hierarchical approach to evaluating the significance of soil biodiversity to biogeochemical cycling. Plant and Soil, v. 170, p. 5-22, 1995.

BECKETT, P.H.R.T. The use of extractants in studies on trace metals in soils, sewage sludges and sludgetreated soils. Advances in Soil Science, v. 9, p. 143-176, 1989.

BEHEL, D.; NELSON, J.R.; SOMMERS, L.E. Assessment of heavy metal equilibria in sewage sludgetreated soil. Journal of Environmental Quality, v. 12, p. 181-186, 1983.

BELL, P.F.; JAMES, B.R.; CHANEY, R.L. Heavy metal extractability in long-term sewage sludge and metal salt-amended soils. Journal of Environmental Quality, v. 20, p. 481-486, 1991.

BENJAMIN, M.M.; LECKIE, J.O. Effects of complexation by $\mathrm{Cl}, \mathrm{SO}_{4}$ and $\mathrm{S}_{2} \mathrm{O}_{3}$ on adsorption behaviour of Cd on oxide surfaces. Environmental Science and Technology, v. 16, p. 162-170, 1982.

BERROW, M.L.; STEIN, W.M. Extration of metals from soils and sewage sludges by refluxing with aqua regia. Analyst, v. 108, p. 277-285, 1983.

BERTI, W.R.; JACOBS, L.W. Distribution of trace elements in soil from repeated sewage sludge applications. Journal of Environmental Quality, v. 27, p. 1280-1286, 1998.

BERTON, R.S. Perigos do uso excessivo de fertilizantes e corretivos no solo. In: SIMPÓSIO DE AGRICULTURA ECOLÓGICA, 1., Campinas, 1993. Anais. Campinas: Fundaçäo Cargill, 1993. p.164-186.

BERTON, R.S. Reciclagem de resíduos urbanos na agricultura: composto de lixo. In: ENCONTRO BRASILEIRO SOBRE SUBSTÂNCIAS HÚMICAS, 2., São Carlos, 1997. Anais. São Carlos: Embrapa, 1997. p. 112-116.

BERTON, R.S. Riscos de contaminação dos agroecossistema com metais pesados. In: SEMINÁRIO SOBRE GERENCIAMENTO DE BIOSÓLIDOS DO MERCOSUL, 2., Campinas. 1999. Anais. Campinas: Embrapa. /no prelo/.

BERTON, R.S.; VALADARES, J.M.A.S. Potencial agrícola do composto de resíduos sólidos urbanos urbano no estado de Säo Paulo. O Agronómico, v. 43, n. 2/3, p. 87-93, 1991.

BERTONCINI, E.I. Mobilidade de metais pesados em solos tratados com lodo de esgoto. Piracicaba, 1997. 90 p. Dissertação (Mestrado) - Escola Superior de Agricultura "Luiz de Queiroz", Universidade de São Paulo.

BERTONCINI, E., MATTIAZZO, M.E. Lixiviação de metais pesados em solos tratados com lodo de esgoto. Revista Brasileira de Ciência do Solo, v. 23, p. 737-744, 1999.

BINGHAM, F.T. Relation between phosphorus and micronutrients in plants. Soil Science Society of America Proceedings, v. 27, p. 389-391, 1963.

BINGHAM, F.T.; PAGE, A.L.; STRONG, J.E. Yield and cadmium content of rice grain in relation to addition rates of cadmium copper, nickel, and zinc with sewage sludge and liming. Soil Science, v. 130, p. $32-38,1980$.

BINGHAM, F.T.; PAGE, A.L.; MAHLER, R.J. et al. Growth and cadmium accumulation of plants grown on a soil treated with a cadmium-enriched sewage sludge. Journal of Environmental Quality, v. 4, p. 207-211, 1975. 
BISSANI, C. A.; MORAES, S.P;; CAMARGO, F. A. O. et al. Alterações nas propriedades químicas de solos sob adiçäo contínua de composto de lixo urbano domiciliar (compact disc). In: CONGRESSO BRASILEIRO DE CIÉNCIA DO SOLO, 26., Rio de Janeiro, 1997.Trabalhos. Rio de Janeiro: SBCS, 1997.

BOLAN, N.S.; NAIDU, R.; KHAN, M.A.R. et al. The effects of anion sorption on sorption and leaching of cadmium. Australian Journal of Soil Research, v. 37, p. 445-460, 1999.

BOLLAND, M.D.A; POSNER, A.M.; QUIRK, J.P. Zinc adsorption by goethite in the absence and presence of phosphate. Australian Journal of Soil Research, v. 15, p. 279-286, 1977.

BOURLAG, N.E. La revolución verde, paz y humanidad. México: Centro Internacional de Mejoramiento de Maiz yTrigo. Serie reimpresos y traducciones n. $31972.35 \mathrm{p}$.

BOURLAG, N.E. Nutritional improvement of food legumes by breeding. In: UPGRADING HUMAN NUTRITION THROUGH THE IMPROVEMENT OF FOOD LEGUMES. Rome, 1973. Proceedings. Rome: Food and Agriculture Organization. 1973. p. 7-11.

BRAMS, E.; ANTHONY, W. Residual cadmium in a soil profile and accumulation i wheat grain. Plant and Soil, v. 109, p. 3-8, 1988.

BRASIL. Leis, decretos, etc. Portaria $n^{\circ} 16$ de 13 de março de 1990. Diário Oficial, 15 mar. 1990. Seção 1, p. 5436. Fixa limites máximos de tolerância de chumbo em alimentos.

BRASIL Ministério da Saúde. Secretaria de Vigilância Sanitária. Portaria $n^{\circ} 685$ de 27 de agosto de 1998. Diário Oficial, 28 ago. 1998. Seção 1, p. 3172-3175. Republicada em 24 set. 1998. Princípios Gerais para o Estabelecimento de Niveis Máximos de Contaminantes Químicos em Alimentos e seu Anexo". ASSOCIAÇÃO BRASILEIRA DAS INDÚSTRIAS DA ALIMENTAÇÃO. Revisão 7. 1998.

BRASIL. Leis, decretos, etc. Lei 9832 de 14 set. 1999: embalagens metálicas industriais - solda de chumbo. Proibe o uso industrial de embalagens metálicas soldadas com liga de chumbo e estanho para acondiconamento de generos alimentícios, exceto para produtos secos ou desidratados. In: FOOD base: legislação sobre alimentos Săo Paulo: Vox/Food Staff, 1999. CD-ROM.

BRAUDE, G.L.; NASH, A. M.; WOLF, W.J. et al. Cadmium and lead content of soybean products. Journal of Food Science, v. 45, p. 1187-1199, 1980.

BROOKES, P.C. The use of microbial parameters in monitoring soil pollution by heavy metals. Biology and Fertility of Soils, v.19, p. 269-279, 1995.

BROWN, J.C.; JONES, W.E. Heavy metal toxicity in plants. 1. A crisis in embryo. Communications in Soil Science and Plant Analysis, v. 6, n. 4, p. 421-438, 1975.

BROWN, S.L.; CHANEY, R.L; ANGLE, J.S. et al. The phytoavilability of cadmium to lettuce in long-term biosolids-amended soils. Journal of Environmental Quality, v. 27, p. 1071-1078, 1998.

BROWN, S.L.; XUE, Q.; CHANEY, R.L. et al. Effect of biosolids processing on the bioavailability of $\mathrm{Pb}$ in urban soils. In: BIOSOLIDS MANAGEMENT INNOVATIVE TREATMENT TECHNOLOGIES AND PROCESSES, Chicago, 1997. Proceedings. Chicago: Water Environment Research Foundation, 1997. p. 43-54.

BRUN, L.A.; MAILLET, J.; RICHARTE, J.; et al. Relationships between extractable copper, soil properties and copper uptake by wild plants in vineyard soils. Environmental Pollution, v. 102, p. 151-161, 1998.

BRUNNER, P.H.; BACCINI, P. Regional material management and environmental protection. Waste Management \& Research, v. 10, p. 203-212, 1992.

BUERGE, I.J.; HUG, S.J. Influence of organic ligands on chromium (VI) reduction by iron (II). Environmental Science and Technology, v. 32, p. 2092-2099, 1998. 
BURG, R. von; LIU, D. Toxicology uptake. Journal of Applied Toxicology, v. 13, n. 3, p. 225-230, 1993.

CABRERA, F.; DIAZ, E.; MADRID, L Effect of using urban compost as manure on soil contents of some nutrients and heavy metals. Journal of the Science and Food and Agriculture., v. 47, p. 159-169, 1989.

CALEGARI, A.; PAVAN, M.A. Efeitos da rotação de milho com adubos verdes de inverno na agregação do solo. Arquivo de Biologia e Tecnologia. v. 38, n. 1, p. 45-53, 1995.

CAMARGO, O.A.; ROVERS, H.; VALADARES, J.M.A.S. Adsorçäo de níquel em latossolos paulistas. Revista Brasileira de Ciência do Solo, v. 13, p. 125-129, 1989.

CAMARGO, O.A.; VALADARES, J.M.A.S.; DECHEN, A.R. Efeitos do $\mathrm{pH}$ e da incubação na extração do manganês, zinco, cobre e ferro do solo. Revista Brasileira de Ciência do Solo, v.6, p.83-88, 1982.

CANDELARIA, L.M.; CHANG, A.C. Cadmium activitie, solution speciation, and solid phase distribution of $C d$ in cadmium nitrate and sewage sludge-treated soil systems. Soil Science, v. 162, n. 10, p. 722-740, 1997.

CARDOSO, E.J.B. Degradação de resíduos orgânicos pela microbiota do solo. In: REUNIÄO BRASILEIRA DE FERTILIDADE DO SOLO E NUTRIÇÃO DE PLANTAS, 20.; SIMPÓSIO: O SOLO COMO MEIO DE DESCARTE E DEGRADAÇÃO DE RESIDUOS, Piracicaba, 1992. Anais. Piracicaba: SBCS; Fundação Cargill, 1992 a. p. 179-193.

CARDOSO, E.J.B. Efeito da matéria orgânica na biologia do solo. In: ENCONTRO SOBRE MATÉRIA ORGÅNICA DO SOLO: PROBLEMAS E SOLUÇÕES, Botucatu, 1992. Anais. Botucatu: UNESP, Faculdade de Ciências Agronômicas, 1992 b. p. 37-62.

CARMO, J.B. Compostos de lixo urbano do município de São Paulo. I. Maturação de compostos. Piracicaba: ESALQ, Depto. Química, 1998. 63 p. (Relatório científico relativo a auxillio pesquisa. FAPESP processo $n^{\circ} 1996 / 06223-4$ )

CASARINI, D.C.P. Padrőes de Qualidade de Solo e Água Subterrânea. In: WORKSHOP SOBRE BIODEGRADAÇÃO. Campinas, 1996. Anais. Jaguariúna: Embrapa, CNPMA. 1996. p. 21-38.

CASSMAN, K.G.; MUNNS, D.N. Nitrogen mineralization as affected by soil moisture, temperature, and depth. Soil Science Society of America Journal. v. 44, p.1233-1237. 1980.

CASTILHO, P. del; CHARDON, W.J. Uptake of soil cadmium by three field crops and its prediction by a pH-dependent Freundlich sorption model. Plant and Soil. v. 171, p. 263-266, 1995.

CASTILLO, A.S.; TRINCA, C.R.; CASANOVA, E. Efecto de la incorporacion de residuos organnicos sobre la dinamica del fosforo en un alfisol degradado del estado Yaraccuy, Venezuela (compact disc). In: CONGRESSO LATINO AMERICANO DE SUELO, 13., Aguas de Lindóia, 1996. Solo-suelo 96: trabalhos. Piracicaba: SBCS, SLCS, 1996.

CASTRO, O.M.; CAMARGO, O.A.; CANTARELLA, H. et al. Teores de zinco, cobre, manganês e ferro em dois latossolos sob plantios direto e convencional. Bragantia. v. 51, n. 1, p. 77-84, 1992.

CERRI, C.C.; BERNOUX, M.; VOLKOFF, B.; MORAES, J.L. Dinâmica do carbono nos solos da Amazônia. In: ALVARES, V.H.; FONTES, L.E.; FONTES, M.P.F. O solo nos grandes domínios morfoclimáticos do Brasil e o desenvolvimento sustentado. Viçosa: SBCS;UFV, 1996. p. 61-69.

CEUSTER, T.J.J.; HOITINK, H.A.J. Using compost to control plant diseases. Biocycle. v.40, n.61-64, Jun, 1999. 
CHABOUSSOU, F. Plantas doentes pelo uso de agrotóxicos: a teoria da trofobiose. Porto Alegre: L \& PM. 1987, $256 \mathrm{p}$.

CHANEY, R.L. Public health and sludge utilization - food chain impact. Biocycle, v. 31, n. 10, p. 68-73, Oct. 1990a.

CHANEY, R.L. Twenty years of land application research - regulating beneficial use. Biocycle, v. $31, n .9$, p. $54-59$, Sept. 1990 b.

CHANEY, R.L. Zinc phytotoxity. In: ROBSON, A.D. Zinc in soils and plants. Dordrecht: Kluwer Academic, 1993. cap. 10, p. 135-150.

CHANEY, R.L. Trace metal movement soil-plant systems and bioavailability of biosolids-applied metals. In: CLAPP, C.E.; LARSON, W.E.; DOWDY, R. H. Sewage sludge: land utilization and the environment. Madison: SSSA, 1994. cap. 5, p. 27-31.

CHANEY, R.L.; OLIVER, D.P. Sources, potencial adverse effects and remediation of agricultural soil contaminants. In: NAIDU, R. Contaminants and the soil environment in the Australasia-Pacific Region. London: Kluwer Academic, 1996. cap. 11, p. 323-359.

CHANEY, R.L. RYAN, J.A. Heavy metals and toxic organic pollutants in MSW-Composts: research results on phytoavailablity, bioavailability, fate, etc. In: HOITINK, H.A.J.; KEENER, H.M. Science and engineering of composting. Worhington: Renaissance Publ., 1993. p. 451-506.

CHANEY, R.L; BROWN, S.L; ANGLE, J.S. Soil-root interface: ecosystem health and human food-chain protection. In: HUANG, P.M. Soil chemistry and ecosiystem health. Madison: SSSA, 1998a. cap. 10, p. 279-311.

CHANEY, R.L.; GREEN, C.E.; FILCHEVA, E. et al. Effect of iron, manganese, and zinc enriched biosolids compost on uptake of cadmium by Lettuce from cadmium-contaminated soils. In: CLAPP, C.E.; LARSON, W.E.; DOWDY, R. H. Sewage sludge: land utilization and the environment. Madison: SSSA, 1994. cap. 27 . p. 205-207.

CHANEY, R.L; LI, Y.M.; SCHNEITER, A.A. et al. Progress in developing technologies to produce low Cd concentration sunflower kernels. In: SUNFLOWER RESEARCH WORKSHOP, 15., Fargo, 1993. Proceedings. Bismark: National Sunflower Association. 1993. p. 80-92.

CHANG, A.C.; HYUN, H.; PAGE, A.L Cadmium uptake for swiss chard grown on composted sewage sludge treated field plots: plateau or time bomb ? Journal of Environmental Quality, v. 26, p. 11-19, 1997.

CHANG, A.C.; PAGE, A.L.; BINGHAM, F.T. Heavy metal absorption by winter wheat following termination of cropland sludge applications. Journal of Environmental Quality, v. 11, n. 4, p. 705-708, 1982.

CHANG, A.C.; PAGE, A.L.; WARNEKE, J.E. Long-term applications on cadmium and zinc accumulation in swiss Chard and Radish. Journal of Environmental Quality, v. 16, p. 217-221, 1987.

CHANG, A.C.; PAGE, A.L.; WARNEKE, J.A. et al. Sequencial extraction of soil heavy metals following a sludge application. Journal of Environmental Quality, v. 13, p. 33-38, 1984a.

CHAUDRI, A.M.; McGRATH, S.P.; GILLER, K.E. Metal tolerances of Rhizobium leguminosarum bv trifolli from soil contaminated by past applications of sewage sludge. Soil Biology and Biochemistry, v. 24, p. 625-632, 1992.

CHEN, M.; MA, L.Q.; HARRIS, W.G. Baseline concentrations of 15 elements in Florida surface soils. Journal of Environmental Quality, v. 28, p. 1173-1181, 1999. 
CHITOLINA, J.C. Compostos de lixo urbano do município de São Paulo. I. caracterização química. Piracicaba: ESALQ, Depto. Química, 1998 a. 72 p. (Relatório científico relativo a auxilio pesquisa. FAPESP processo $n^{\circ} 1996 / 4049-7$ )

CHITOLINA, J.C. Compostos de lixo urbano do município de São Paulo. II. especiação de metais pesados. Piracicaba: ESALQ, Depto. Química, 1998 b. 52 p. (Relatório científico relativo a auxilio pesquisa. FAPESP processo $n^{0} 1996 / 4049-7$ )

CHOWDHURY, A.K.; MCLAREN, R.G.; CAMERON, K.C. et al. Fractionation of zinc in some New Zealand soils. Communications in Soil Science and Plant Analysis, v. 28, n. 3/5, p. 301-312, 1997.

CHUMBLEY, C.G.; UNWIN, R.J. Cadmium and lead content of vegetable crops grown on land with a history of sewage sludge application. Environmental Pollution. Series B, v. 4, p. 231-237, 1981.

CIESLINSKI, G.; MERCIK, S.; NEILSEN, G. Effect of soil application of cadmium contaminated lime on soil cadmium distribution and cadmium concentration in strawberry leaves and fruit. Journal of Plant Nutrition, $\quad$ v. 17, n. 7, p. 1095-1110, 1994.

CIESLINSKI, G.; RESS, K.C.J. van; SZMIGIELSKA, A.M. et al. Low-molecular-weight organic acids in rhizosphere soils of durum wheat and their effect on cadmium bioaccumulation. Plant and Soil, v. 203, p. 109-117, 1998.

COKER, E.G.; MATTHEWS, P.J. Metals in sewage sludge and their potential effects in agriculture. Water Science and Technology, v. 15, p. 209-225, 1983.

COLLIER, L.S.; VELLOSO A.C.X.; AMARAL SOBRINHO, N.M.B. Distribuiçăo de metais pesados em solo glei tratado com composto de resíduo urbano. (compact disc). In: CONGRESSO BRASILEIRO DE CIEENCIA DO SOLO, 26., Rio de Janeiro, 1997. Trabalhos. Rio de Janeiro: SBCS, 1997.

COMPANHIA DE TECNOLOGIA E SANEAMENTO AMBIENTAL. Inventário estadual de resíduos sólidos domiciliares - relatório síntese. v. 1. Diário Oficial do Estado de São Paulo-suplemento. v. 109,

COMPOSTING in Brazil. Biocycle, v. 25, n. 6, p. 36,37, Sept. 1984.

COREY, R.B.; KING, L.D.; LUE-HING C. et al. Effects of sludge properties on accumulation of trace elements by crops. In: PAGE, A.L.; LOGAN, T.J.; RYAN, J.A. Land application of sludge: food chain implications. Chelsea: Lewis Publ., 1987. cap. 3, p. 25-51.

COSTA, C.A. Crescimento e teores de sódio e de metais pesados da alface e da cenoura adubadas com composto orgânico de lixo urbano. Viçosa, 1994. 89 p. Dissertação (Mestrado) - Universidade Federal de Viçosa.

COSTA, C.A.; CASALI, V.W.; LOURES, E.G. et al. Teores de metais pesados em alface (Lactuca sativa L) adubada com composto orgânico de lixo urbano. Revista Ceres, v. 41, n. 238, p. 629-640, 1994 a.

COSTA, C.A.; SANTOS, I.C.; CASALI, V.W. et al. Redução da absorção de cádmio pela alface cV BR-221 por meio do cultivo com composto orgânico. Horticultura Brasileira, v. 12, n. 2, p. 136-139, nov. 1994 b.

CRAVO, M.S. Composto de lixo urbano como fonte de nutrientes e metais pesados para alface. Piracicaba. 1995. 148 p. Tese (Doutorado) - Centro de Energia Nuclear na Agricultura, Universidade de Såo Paulo.

CRAVO, M.S.; MURAOKA, T.; GINÉ, M.F. Caracterização química de compostos de lixo urbano de algumas usinas brasileiras. Revista Brasileira de Ciência do Solo, v. 22, p. 547-553, 1998.

CUNHA, R.C.; CAMARGO, O.A.; KINJO, T. Aplicação de très isotermas na adsorção de zinco em oxissolos, alfissolos e ultissolos. Revista Brasileira de Ciência do Solo, v. 18, p. 15-20, 1994 a. 
CUNHA, R.C.; CAMARGO, O.A.; KINJO, T. Retenção de zinco em solos paulistas. Bragantia, v. 22, p. 291-301, 1994b.

CUNNINGHAM, J.D.; KEENEY, D.R.; RYAN, J.A. Phytotoxicity and uptake of metals added to soil as inorganic salts or in sewage sludge. Journal of Environmental Quality, v. 4, n. 4, p. 460-462, 1975a.

CUNNINGHAM, J.D.; RYAN, J.A; KEENEY, D.R. Phytotoxicity in and metal uptake from soil treated with metal-amended sewage sludge. Journal of Environmental Quality, v.4, p. 455-460, 1975b.

CUTLER, J.M.; RAINS, D.W. Characterization of cadmium uptake by plant tissue. Plant Physiology, v. 54, p. $67-71,1974$.

DAHLIN, S.; WITTER, E.; MARTENSSON, A. et al. Where's the limit? Changes in the microbiological properties of agricultural soils at low levels of metal contamination. Soil Biology and Biochemistry. $v$. 29 , n. 9 , p. $1405-1415,1997$.

DAS, P.; SAMANTARAY, S.; ROUT, G.R. Studies on cadmium toxicity in plants: a review. Environmental Pollution, v. 98, n. 1, p. 29-36, 1997.

DAVIES, B.E. Lead. In: ALLOWAY, B.J. Heavy metals in soils. London: Blackie Academic \& Professional, 1995. cap. 9, p.206-223.

DAXBECK, H; BRUNNER, P.H. Regional material balances as a tool for environmental monitoring. In: INTERNATIONAL SYMPOSIUM ON ENVIRONMENTAL CONTAMINATION IN CENTRAL AND EASTERN EUROPE: "A FORUM FOR TECHNOLOGY TRANSFER", Budapest, 1992. Proceedings. Budapest:: s.ed., 1992. 4 p.

DEPARTAMENTO DE ÁGUAS E ENERGIA ELÉTRICA. Atlas pluviométrico do Estado de São Paulo (periodo 1941 - 1970). São Paulo, 1972. 84 p.

DE VRIES, M.P.C.; TILLER, K.G. Sewage sludge as a soil amendment, with special reference to $\mathrm{Cd}$, $\mathrm{Cu}$, $\mathrm{mn}, \mathrm{Ni}, \mathrm{Pb}$, and $\mathrm{Zn}$ - comparasion of results from experiments conducted inside and outside a glasshouse. Environmental Pollution, v. 16, p. 231-240, 1978.

DIAS, C.L.; LEMOS, M.M.G.; CAPELETI, A.R. et al. Derivação de valores de intervenção para chumbo, benzeno e tetracloroetileno, utilizando o modelo de avaliação de risco C-soil, para controle da contaminação de solos e águas subterrâneas no estado de Säo Paulo (compact disc). In: CONGRESSO BRASILEIRO DE ÁGUAS SUBTERRÂNEAS, 10., São Paulo, 1998. Trabalhos. São Paulo: ABAS, 1998.

DICKINSON, N.M.; LEPP, N.W.; ORMAND, K.L. Copper contamination of a 68 year old Coffea arabica L. plantation. Environmental Pollution. Series B. v. 7, p. 223-231, 1984.

DICKINSON, N.M.; LEPP, N.W.; SURTAN, G.T.K. Further studies on copper accumulation in Kenyan Coffea arabica plantations. Agricultural Ecosystems and Environment, v. 21, p. 181-190, 1988.

DOELMAN, P.; HAANSTRA, L. Effect of lead on soil respiration and dehidrogenase activity. Soil Biology and Biochemistry, v. 11, p. 475-479, $1979 a$.

DOELMAN, P.; HAANSTRA, L. Effect of lead on the decomposition of organic matter. Soil Biology and Biochemistry, v. 11, p. $481-485,1979 b$.

DOELMAN, P.; HAANSTRA, L. Effect of lead on the soil bacterial microflora. Soil Biology and Biochemistry, v. 11, p. 487-491, 1979c.

DOELMAN, P.; JANSEN, E.; MICHELS, M. et al. Effects of heavy metals in soil on microbial diversity and activity as shown by the sensitivity-resistance index, an ecologically relevant parameter. Biology and Fertility of Soils, v. 17, p. 177-184, 1994. 
DONER, H.E. Chloride as a factor in mobilities of Ni (II), Cu (II) and Cd (II) in soil. Soil Science Society of America Journal, v. 42, p. 882-885, 1978.

DOWDY, R.H.; LATTERELL, J.J. HINESLY, T.D. et al. Trace metal movement in and aeric ochraqualf following 14 years of annual sludge applications. Journal of Environmental Quality, v. 20, p. 119 $123,1991$.

DUDKA, S.; ADRIANO, D.C. Environmental impacts of metal ore mining and processing: a review. Journal of Environmental Quality, v. 26, p. 590-602, 1997.

DUDKA, S: CHLOPECKA, A. Effect of solid-phase speciation on metal mobility and phytoavailability in sludge-amended soil. Water, Air and Soil Pollution, v. 51, p. 153-160, 1990.

ECHEVERRIA, J.; MORERA, T:; GARRIDO, J. Metal-induced chromium (VI) sorption by two calcareous soils Australian Journal of Soil Research, v. 37, p. 431-443, 1999.

ECHEVERRIA, J.C.; MORERA, M.T.; MAZKIARÁN, C. et al. Competitive sorption of heavy metal by soils. Isotherms and fractional factorial experiments. Environmental Pollution, v. 101, p. 275-284, 1998.

EDWARDS, R.; LEPP, N.W.; JONES, K.C. Other less abundant elements of potential environment significance. In: ALLOWAY, B.J. Heavy metals in soils. London: Blackie Academic \& Professional, 1995. cap. 14 , p.306-352.

EGREJA FILHO, F.B. Avaliação da ocorrência e distribuição quimica de metais pesados na compostagem do lixo domiciliar urbano. Viçosa. 1993. 176 p. Dissertação (Mestrado) - Universidade Federal de Viçosa.

EHRLICH, H.L. Microbes and metals. Applied Microbiology Biotechnology. v. 48, p. 687-692, 1997.

EICK, M.J.; PEAK, J.D.; BRADY, P.V. et al. Kinetcs of lead adsorption/desorption on goethite: residence time effect. Soil Science, $\quad$ v. 164, n. 1, p. 28-39, 1999.

EL-BASSAM, N.; TIETJEN, C. Municipal sludge as organic fertilizer with special reference to the heavy metals constituents. In: SYMPOSIUM ON SOIL ORGANIC MATTER STUDIES, Viena, 1977. Proceedings. Viena: International Atomic Energy Agency; F.A.O. 1977. v.2, p.253-258.

ELLIOTT, H.A.; LIBERATI, M.R.; HUANG, C.P. Competitive adsorption of heavy metals by soils. Journal of Environmental Quality, v. 15, p. 214-217, 1986.

EMPRESA BRASILEIRA DE PESQUISA AGROPECUARIA Serviço Nacional de Levantamento e Conservação de Solos. Manual de métodos de análise de solo. Rio de Janeiro, 1979. 1V.

ENVIRONMENTAL PROTECTION AGENCY. A guide to the biosolids risk assessments for the EPA Part 503 Rule. Washington, 1995. $144 \mathrm{p}$.

ESSINGTON, M.E.; MATTIGOD, S.V. Trace element solid-phase associations in sewage sludge and sludge-amended soil. Soil Science Society of America Journal, v. 55, p. 350-356, 1991.

FAO. Codex alimentarius: general standard for contaminants and toxins in foods. Rome, $1998.139 \mathrm{p}$.

FAO. Codex Alimentarius Comission. Draft maximum levels for lead. Rome, 1999 a. $19 \mathrm{p}$.

FAO. Codex Alimentarius Comission. Methodology and principles for exposure assesment in the codex general standard for contaminants and toxins in food. Rome, 1999 b. $23 \mathrm{p}$.

FAO. Codex Alimentarius Comission. Request for Comments on the proposed draft code of practice for source directed measures to reduce contamination of food with chemicals. Rome, $1999 \mathrm{c}$. $2 \mathrm{p}$. 
FASSBENDER, H.W.; BORNEMISZA, E. Química de suelos: con énfasis en suelos de América Latina. San José: IICA, 1987. $420 \mathrm{p}$.

FELLEMBERG, G. Introdução aos problemas de poluição ambiental. São Paulo: EDUSP, 1980. 196 p.

FIGUEIREDO, P. J.M. A sociedade do lixo: os resíduos, a questão energética e a crise ambiental. Piracicaba: Editora UNIMEP, 1994. 240 p.

FORTES NETO, P.; SELBACH, P.A. Compostagem natural do lixo domiciliar urbano através de leiras estáticas e revolvidas. In: WORKSHOP SOBRE BIODEGRADAÇÃO, Campinas, 1996. Anais. Jaguariúna: Embrapa, CNPMA, 1996. p. 226.

FREEDMAN, B.; HUTCHINSON, T.C. Source of metal and elemental contamination of terrestrial environments. In: LEPP, N.W. Effect of heavy metal pollution on plants. London: Applied Science, 1981. v.2, cap. 2 , p. 35-94.

FREEMAN, G.B.; JOHNSON, J.D.; KILLINGER, J.M. et al. Relative bioavailability of lead from mining waste soil in rats. Fundamental and Applied Toxicology, v. 19, p. 388-398, 1992.

FROSTEGARD, A.; TUNLID, A; BAATH, E. Phospholipid fatty acid composition biomass and activity of microbial communities from two soil types experimentally exposed to different metals. Applied and Environmental Microbiology, v. 59, p. 3605-3617, 1993.

FROSTEGARD, A.; TUNLID, A; BAATH, E. Changes in microbial community structure during long-term incubation in two soils experimentally contaminated with metals. Soil Biology and Biochemistry. $v$. 28, p. 55-63, 1996.

GABE, U.; RODELLA, A.A. Trace elements in brazilian agricultural limestones and mineral fertilizers. Communications in Soil Science and Plant Analysis, v. 30, n. 5/6, p. 605-620, 1995.

GILLER, K.E.; WITTER, E.; MCGRATH, S.P. Toxicity of heavy metals to microorganisms and microbial processes in agricultural soils: a review. Soil Biology and Biochemistry, v. $30, n .10 / 11$, p. $1389-1414,1998$.

GIUSQUIANI, P.L.; GIGLIOTTI, G.; BUSINELLI, D. Mobility of heavy metals in urban waste-amended soils. Journal of Environmental Quality, v. 21, $\quad$ p. $330-335,1992$.

GODO, G.H.; REISENAUER, H.M. Plant effects on soil manganese availability. Soil Science Society of America Journal, v. 44, p. 993-995, 1980.

GOMES, P.C. Fracionamento e biodisponibilidade de metais pesados influenciados por calagem e concentraçöes de metais em latossolo vermelho-amarelo. Viçosa, 1996. 161 p. Tese (Doutorado) Universidade Federal de Viçosa.

GOMES, P.C.; FONTES, M.P.F.; COSTA, L.M. et al. Fracionamento de metais pesados influenciados por horizontes e calgem em latossolo vermelho-amarelo. In: SIMPÓSIO NACIONAL DE RECUPERAÇÃO DE ÁREAS DEGRADADAS, 3., Ouro Preto, 1997. Anais. Ouro Preto: SOBRADE, 1997. p. 249-256.

GORGATI, C.Q. Estudo da fração orgânica de lixo urbano como substrato para biodigestor e como matéria-prima para vermicompostagem. Jaboticabal, 1993. 70 p. Trabalho (Graduação) - Faculdade de Ciências Agrárias e Veterinárias, Universidade Estadual Paulista "Julio de Mesquita Filho".

GROSSI, M.G.L. Avaliação da qualidade dos produtos obtidos de usinas de compostagem brasileiras de lixo doméstico através da determinação de metais pesados e substâncias orgânicas tóxicas. São Paulo, 1993. 222 p. Tese (Doutorado) - Instituto de Química, Universidade de Såo Paulo.

GUILHERME, L.R.G. Poluição do solo e qualidade ambiental. (compact disc) In: CONGRESSO BRASILEIRO DE CIÉNCIA DO SOLO, 27., Rio de Janeiro. 1999. Palestras. Brasília: SBCS, 1999. 
GUPTA, U.C. Factors affecting boron uptake by plants. In: GUPTA, U.C. Boron and its role in crop production. Boca Raton: CRC Press, 1993. cap. 5, p. 87-104.

GUPTA, U.C.; LIPSETT, J. Molybdenum in soils plants and animals. Advances in Agronomy, v. 34, p. $73-115,1981$.

GUPTA, U.C.; JAME, Y.W:; CAMPBELL, C.A. et al. Boron toxicity and deficiency: a review. Canadian Journal of Soil Science, v. 65, n. 3, p. 381-409, 1985.

HAAN, S. Results of municipal waste compost research over more than fifty years at the Institute for Soil Fertility at Haren/Groningen, the Netherlands. Netherlands Journal of Agricultural Science, v. 29, p. $49-61,1981$.

HAMMER, S.A. Garbage in/garbage out: a hard look at mixed municipal solid waste composting. Resource Recycling, v.11, n.2, p.40, 42-44, Feb. 1992.

HAMON, R.E.; MCCLAUGHLIN, M.J.; NAIDU, R. et al. Long-term changes in cadmium bioavailability in soil. Environmental Science and Technology, v.32, p. 3699-3703, 1998.

HANNAM, R.J.; OHKI, K. Detection of manganese deficiency and toxicity in plants. In: GRAHAM, R.D.; HANNAM, R.J.; UREN, N.C. Manganese in soils and plants. Dordrecht: Kluwer Academic, 1988. cap. 16 , p. $243-259$.

HARRISON, N. Metals. In: WATSON, D.H. Safety of chemicals in food chemical contaminants. London: Ellis Horwood, 1993. cap. 7, p. 109-124.

HARRISON, R.M. Physico-chemical speciation and chemical transformations of toxic metals in the environment. In: COUGHTREY, P.J.; MARTIN, M.H.; UNSWORTH, M.H. Pollutant transport and fate in ecosystems. Oxford: Blackwell Scientific, 1987. p.239-247. (British Ecological Society Special Publication, 6).

HARTER, R.D. Effect of soil pH on adsorption of lead, copper, zinc and nickel. Soil Science Society of America Journal, v. 47, p. 47-51, 1983.

HE, Q.B.; SINGH, B.R. Plant availability of cadmium in soil. I. Extractable cadmium in newly and long-term cultivated soils. Acta Agriculturae Scandinavica, v. 43, p. 134-141, 1993 a.

HE, Q.B.; SINGH, B.R. Plant availability of cadmium in soils.II. Factors related to the extractability and plant uptake of cadmium in cultivated soils. Acta Agriculturae Scandinavica, Section B. Soil and Plant Science, v. 43, p. 142-150, 1993 b.

HE, X.T.; LOGAN, T.J.; TRAINA, S.J. Physical and chemical characteristics of selected u.s. municipal solid waste composts. Journal of Environmental Quality, v. 24, p. 543-552, 1995.

HE, X.T.; TRAINA, S.J.; LOGAN, T.J. Chemical properties of municipal solid waste composts. Journal of Environmental Quality, v. 21, p. 318-329, 1992.

HERNANDEZ, T.; GARCIA, C.; COSTA, F. et al. Utilizacion de residuos urbanos como fetilizantes organicos. Suelo y Planta, v.2, p. 373-383, 1992.

HILL, R.L.; JAMES, B.R. The influence of waste amendments on soil properties. In: RECHCIGL, J.E. Soils amendments and environmental quality. Boca Raton: Lewis Publishers, 1995. cap. 8, p. 311-326.

HOLM, P.E.; CHRISTENSEN, T.H.; TJELL, J.C.; MCGRATH, S.P. Speciation of cadmium and zinc with application to soil solutions. Journal of Environmental Quality, v. 24, p. 183-190, 1995.

HOROWITZ, A.; DANTAS, H.S. Boro disponivel nos solos da zona litoral-mata de Pernanbuco. Pesquisa Agropecuária Brasileira, v. 8, p. 163-168, 1973a. 
HOROWITZ, A; DANTAS, H.S. Geoquímica dos elementos menores nos solos de Pernambuco. III. Cobre na zona litoral-mata. Pesquisa Agropecuária Brasileira, v. 8, p. 169-176, 1973b.

HOWARD, A An agricultural testament. New York: Oxford \& Rodale Press, 1943. 253 p.

HOVI, A. Source separation project of organic household waste. Lahti: University of Helsinki. Lahti Research and Training Centre, 1992. 7p. IApresentado ao IX Congresso da IFOAM, São Paulo, 1992/

HSIEH, Y.P.; DOUGLAS, L.A.; MOTTO, H.L. Modeling sewage sludge decomposition in soil: Nitrogen transformation. Journal of Environmental Quality, v. 10, n. 1, p. 59-64, 1981.

HUBER, D.M.; WILHELM, N.S. The role of manganese in resistance to plant diseases. In: GRAHAM, R.D.; HANNAM, R.J.; UREN, N.C. Manganese in soils and plants. Dordrecht: Kluwer Academic, 1988. cap. 11, p. $155-173$.

HUNTJENS, J.L.M.; OOSTERVELD-Van-VLIET, W.M.; SAYED, S.K.Y. The decomposition of organic compounds in soil. Plant and Soil, v. 61, n. 1/2, p. 227-242, 1981.

HUTTON, M.; SYMON, C. Sources of cadmium discharge to the UK environment. In: COUGHTREY, P.J.; MARTIN, M.H.; UNSWORTH, M.H. Pollutant transport and fate in ecosystems. Oxford: Blackwell Scientific, 1987. p.223-237. (British Ecological Society Special publication, 6).

IGUE, K.; PAVAN, M.A. Uso eficiente de adubos orgânicos. In: SIMPÓSIO SOBRE FERTILIZANTES ORGÂNICOS NA AGRICULTURA BRASILEIRA, Brasília, 1984. Anais. Brasília: Fundação Cargill, 1984. p. $383-4 \mid 8$.

INESON, P.; ANDERSON, J.M. Aerobically isolated bacteria associated with the gut and faeces of the litter feeding macroarthropods Oniscus asellus and Glomeris marginata. Soil Biology and Biochemistry. v. 17, n. 6, p. 843-849, 1985.

INSTITUTO DE PESQUISAS TECNOLÓGICAS. Lixo municipal: manual de gerenciamento integrado. São Paulo: IPT; CEMPRE, 1995. 278 p.

IRETSKAYA, S.N.; CHIEN, S.H. Comparison in cadmium uptake by five different food grain crops grown on three soils of varying pH. Communications in Soil Science and Plant Analysis, v. $30, n .3 / 4$, p. $441-448,1999$.

JAHNEL, M.C.; CARDOSO, E.J.B.N.; DIAS, C.T.S. Determinaçăo do número mais provável de microrganismos do solo pelo método de plaqueamento por gotas. Revista Brasileira de Ciência do Solo, v. 23, p. 553-559, 1999.

JARDIM, W.F. Metais pesados, um dano irreparável. Metais pesados, um dano irreparável. Revista Brasileira de Tecnologia, v. 14, n. 2, p. 41-45, 1983.

JENKINSON, D.S.; POWLSON, D.S. The effects of biological on metabolis in soil. V. A method for measuring soil biomass. Soil Biology and Biochemistry, v. 8, n. 3, p. 209-213, 1976.

JOHN, M.K. Cadmium uptake by eight food crops as influenced by various soil levels of cadmium. Environmental Pollution, v. 4, p. 7-15, 1973.

JONES, D.L. Organic acids in the rhizosphere - a critical review. Plant and Soil, v. 205, p. 25-44, 1998.

JORGE, J.A.; CAMARGO, O.A; VALADARES, J.M.A.S. Condições físicas de um latossolo vermelhoescuro quatro anos após aplicação de lodo de esgoto e calcário. Revista Brasileira de Ciência do Solo, v. 15, p. $237-240,1991$.

KABATA-PENDIAS, A.; ADRIANO, D.C. Trace metals. In: RECHCIGL, J.E. Soils amendments and environmental quality. Boca Raton: Lewis Publ., 1995. cap. 4, p. 139-168. 
KABATA-PENDIAS, A; PENDIAS, $H$. Trace elements in soils and plants. Boca Raton: CRC Press, 1992. $365 \mathrm{p}$.

KARLEN, D.L.; MAUSBACH, M.J.; DORAN, J.W. et al. Soil quality: a concept, definition, and framework for evaluation (a guest editorial). Soil Science Society of America Journal, v. 61, p. 4-10, 1997.

KATZ, S.A.; SALEM, H. The toxicology of chromium with respect to its chemical speciation: a review. Journal of Applied Toxicology, v. 13, n. 3, p. 217-224, 1993.

KELLER, C.; VEDY, J.C. Distribution of copper and cadmium fractions in two forest soils. Journal of Environmental Quality, v. 23, p. 987-999, 1994.

KENNEDY, A.C.; GEWIN, V. Soil microbial diversity: present and future. Soil Science, v. 162, n. 9, p. $607-$ $617,1997$.

KHALEEL, R.; REDDY, K.R.; OVERCASH, M.R. Changes in soil physical properties due to organic waste applications; a review. Journal of Environmental Quality, v. 10, p. 133-139, 1981.

KHAN, N.A.; AHMAD, A.A.; NOMANI, A.A. et al. Atomic absorption spectrophotometric studies of cadmium and zinc in commercial fertilizers, and soils and river waters. Environmental Pollution. Series B, v. 2, p. 259-264, 1981.

KIEHL, E.J. Manual de edafologia. São Paulo: Ceres, 1979. 262 p.

KIEHL, E.J. Fertilizantes orgânicos. Piracicaba: Agronômica Ceres, 1985. 492 p.

KIERKENS, L. Zinc. In: ALLOWAY, B.J. Heavy metals in soils. London: Blackie Academic \& Professional, 1995. cap. 13, p. 284-305.

KING, L.D. Soil heavy metals. In: ALVAREZ, V.H.; FONTES, L.E.F.; FONTES, M.P.F. O solo nos grandes domínios morfoclimáticos do Brasil e o desenvolvimento sustentado. Viçosa: SBCS; UFV, 1996. p. 823-836.

KPARMWANG, T.; SEU, I.E.; CHUDE, V.O. Available and total forms of copper and zinc in basaltic soils of the nigerian savanna. Communications in Soil Science and Plant Analysis, v. 29, n. 15/16, p. $2235-2245,1998$.

KUBOTA, J; ALLAWAY, W.H. Geographic distribution of trace element problems. In: MORTVEDT, J.J.; GIORDANO, P.M.; LINDSAY, W.L. Micronutrients in agriculture. Madison: Soil Science Society of America Inc. 2 ed. 1973 . Chapter 21, p. 525-554.

KUO, S. Concurrent sorption of phosphate and zinc, cadmium, or calcium by a hydrous ferric oxide. Soil Science Society of America Journal, v. 50, p. $1412-1419,1986$.

KUO, S.; BAKER, A.S. Sorption of copper, zinc and cadmium by some acid soils. Soil Science Society of America Journal, v. 44, p. 969-974, 1980.

KUO, S.; JELLUM, E.J.; BAKER; A.S. Effects of soil type, liming and sludge application on zinc and cadmium availability to swiss chard. Soil Science, v. 139, p. 122-130, 1985.

LAGENBACH, T.; SARPA, M Teor de cádmio nos fertilizantes fosfatados brasileiros. Revista Brasileira de Ciência do Solo,v. 9, p. 179-181, 1985.

LAGERWERFF, J.V; BIERSDORF, G.T.; MILBERG, R.P. et al. Effects of incubation and liming on yield and heavy metal uptake by rye from sewage-sludge soil. Journal of Environmental Quality, v. 6, n. 4, p. $427-431,1977$.

LAGRIFFOUL, A.; MOCQUOT, B.; MENCH, M. et al. Cadmium toxicity effects on growth, mineral and chlorophyll contents, and activities of stress related enzymes in young maize plants (Zea mays L.). Plant and Soil, v. 200, p. 241-250, 1998. 
LAKE, D.J. Chemical speciation of heavy metals in sewage sludge and related matrices. In: LESTER, J.N. Heavy metals in wastewater an sludge treatment process. Boca Raton: CRC Press, 1987 a. v.2, p. $126-148$.

LAKE, D.J. Sludge disposal to land. In: LESTER, J.N. Heavy metals in wastewater an sludge treatment process. Boca Raton: CRC Press, 1987 b. v.2, p. 92-124.

LAMBERT, D.H.; BAKER, D.E.; COLE JR., H. The role of mycorrhizae in the interactions of phosphorus with zinc, copper, and other elements. Soil Science Society of America Journal, v. 43, p. 976-980, 1979.

LAMIM, S.S.M.; JORDÃO, C.P.; BRUNE, W. et al. Caracterização química e físico-química de vermicomposto de esterco bovino e avaliação da adsorção competitiva por cádmio e chumbo. . Química Nova, v. 19, n. 5, p. $457-463,1996$.

LAMY, I.; BOURGEOIS, S.; BERMOND, A. Soil cadmium mobility as a consequence of sewage sludge disposal. Journal of Environmental Quality, v. 22, p. 731-737, 1993.

LASKOWSKI, R. Are the top carnivores endangered by heavy metal biomagnification ? Oikos, v. $60, p$. 387-390, 1991.

LEE, B.D.; CARTER, B.J.; BASTA, N.T. et al. Factors influencing heavy metal distribution in six Oklahoma benchmark soils. Soil Science Society of America Journal, v. 61, p. 218-223, 1997.

LEHOCZKY, É; SZABÓ, L.; HORVÁTH, SZ. et al. Cadmium uptake by lettuce in different soils. Communications in Soil Science and Plant Analysis, v. 29, n. 11/14, p. 1903-1912, 1998.

LEMOS, R.C.; SANTOS, R.D. Manual de descrição e coleta de solo no campo. Campinas: Sociedade Brasileira de Ciência do Solo; Serviço Nacional de Levantamento e Conservaçäo de Solos, 1984. 45 p.

LEPP, N.W. Copper. In: LEPP, N.W. Effect of heavy metal pollution on plants. London: Applied Science Publ., 1981. v.1, cap. 4, p. 111-143.

LE RICHE, H.H.; WEIR, A.H. A method of studying trace elements in soil fractions. Journal of Soil Science, v. 14, p. 225-235, 1963.

LI, M.; HUE, N.V.; HUSSAIN, S.K.G. Changes of metal forms by organic amendments to Hawail soils. Communications in Soil Science and Plant Analysis, v. 28, n. 3/5, p. 381-394, 1997.

LI, Y.M.; CHANEY, R.L.; SCHNEITER, A.A. Effect of soil chloride level on cadmium concentration in sunflower kernels. Plant and Soil, v. 167, p. 275-280, 1994.

LI, Y.M.; CHANEY, R.L.; SCHNEITER, A.A. et al. Genotypic variation in kernel cadmium concentration in sunflower germplasm under varying soil conditions. Crop Science, v. 35, n. 1; p. 137-141, 1995.

LIEBIG, J. von Les Lois Naturelles L'Agriculture. Paris: Libraire Agricole de La Maison Rustique, 1864. v. $1,184 \mathrm{p}$.

LIMA, J.S.; MENK, J.R.F. Estudos preliminares sobre a ação do composto orgânico em algumas propriedades de solos agrícolas. Engenharia Sanitária e Ambiental, v. 2, n. 3/4, p. 96-99, 1997.

LIMA, J.S.; MENK, J.R.F.; LICHTIG, J. et al. Influência do composto orgânico no teor de metais pesados de solos agricolas. Bio Engenharia Sanitária e Ambiental, v.4, n. 3, p. 57-60, 1995.

LIMA FILHO, O.F.; MALAVOLTA, E. Evaluation of extraction procedures on determination of critical soil and foliar levels of boron and zinc in coffee plants. Communications in Soil Science and Plant Analysis, v. 29, n. $7 / 8$, p. $825-833,1998$.

LINDERMANN, W.C.; CARDENAS, M. Nitrogen mineralization potential and nitrogen transformations of sludge-amended soil. Soil Science Society of America Journal, v. 48, p. 1072-1077, 1984. 
LINDSAY, W.L; NORWELL, W.A. Development of a DTPA soil test for zinc, iron, manganese and copper. Soil Science Society of America Journal, v. 42, p. 421-428, 1978.

LOGAN, T.J. Gaining public acceptance for beneficial use of biosolids. Biocycle, v. 36, n. 12, p. $61-64$, 1995.

LOGAN, T.J.; LINDSAY, B.J.; GOINS, LE. et al. Field assessment of sludge metal bioavailability to crops: sludge rate response. Journal of Environmental Quality, v. 26, p. 534-550, 1997.

LOPEZ, A.; PETRUZZELLI, D. Interactions of toxic organics with subsoils components. Ecological Sciences. Series G, v. 32, p. 93-110. 1993.

LUDVIGSEN, L; ALBRECHTSEN, H.J.; RINGELBERG, D.B.; EKELUND, F.; CHRISTENSEN, T.H. Distribution and composition of microbial populations in a landfill leachate contaminated aquifer (Grindsted, Denmark). Microbial Ecology. v. 37, p. 197-207, 1999.

LUN, X.Z; CHRISTENSEN, T.H. Cadmium complexation by solid waste leachates. Water Research, v. 23, p. 81-84, 1989.

LUND, L.J.; PAGE, A.L.; NELSON, C.O. Movement of heavy metals below sewage disposal ponds. Journal of Environmental Quality, v. 5, n. 3, p. 330-334, 1976.

LUO, Y.M.; CHRISTIE, P. Alkaline sewage sludge solids affect the chemical speciation and biovailability of $\mathrm{Cu}$ and $\mathrm{Zn}$ in the rhizosphere soil solution. Soil Science and Plant Nutrition, v. 43, p. 1041-1046, 1997.

LUO, Y.M.; CHRISTIE, P. BioavailabilitY of copper and zinc in soils treated with alkaline stabilized sewage sludges. Journal of Environmental Quality, v. 27, p. 335-342, 1998.

MA, L.Q; RAO, G.N. Chemical Fractionation of cadmium, copper, nickel and zinc in contaminated soils. Journal of Environmental Quality, v. 26, p. 259-264, 1997.

MA, L.Q.; TAN, F; HARRIS, W.G. Concentrations and distributions of eleven metals in Florida soils. Journal of Environmental Quality, v. 26, p. 769-775, 1997.

MACHADO, P.L.O.; PAVAN, M.A. Adsorção de zinco por alguns solos do Paraná. Revista Brasileira de Ciência do Solo, v. 22, p. 253-256, 1987.

MACLEAN, A.J. Cadmium in different plant species and its availability in soils as influenced by organic matter and additions of lime, P, Cd and Zn. Canadian Journal of Soil Science, v. 56, n.3, p. 129-138, 1976.

MACNAUGHTON, S.; STEPHEN, J.R.; CHANG, Y. et al. Characterization of metal-resistant soil eubacteria by polymerase chain reaction - denaturing gradient gel electrophoresis with isolation of resistant strains. Canadian Journal Microbiology, v. 45, p. 116-124, 1999.

MAHLER, R.J.; BINGHAM, F.T.; PAGE, AL Cadmium-enriched sewage sludge application to acid and calcareous soils: effect on yield and cadmium uptake by lettuce and chard. Journal of Environmental Quality, v. 7, n. 2, p. 274-281, 1978.

MAHLER, R.J.; BINGHAM, F.T; PAGE, AL et al. Cadmium-nriched sewage sludge application to acid and calcareous soils: effect on soil and nutrition of lettuce, corn, tomato, and swiss chard. Journal of Environmental Quality, v. 11, n. 4, p. 694-700, 1982.

MALAVOLTA, E. Fertilizantes e seu impacto ambiental: metais pesados, mitos, mistificação e fatos. São Paulo: Produquímica, 1994. 153 p.

MANDAL, B.; HAZRA, G.C. Zinc adsorption in soils as influenced by different soil management practices. Soil Science, v. 162, n. 10, p. 713-721, 1997. 
MANN, S.S.; RITCHIE, G.S.P. The influence of pH on the forms of cadmium in four west australian soils. Australian Journal of Soil Research, v. 31, p. 255-270, 1993.

MANN, S.S.; RITCHIE, G.S.P. Changes in the forms of cadmium with time in some western australian soils. Australian Journal of Soil Research, v. 32, p. 241-250, 1994.

MARCHIORI, A.C.C. Coleta diferenciada de resíduos urbanos. A proposta da CATI para programas de reciclagem. In: ENCONTRO NACIONAL DE RECICLAGEM, AGRICULTURA E MEIO AMBIENTE, Campinas, 1995. Anais. Campinas: CATI, 1995. p. $81-115$.

MARCHIORI, A.C.C.; CHITOLINA, J.C.; GROSSI, D.B.M. et al. Extraçäo sequencial de metais pesados de compostos de lixo urbano de duas usinas de compostagem da grande São Paulo. In: REUNIÃO BRASILEIRA DE FERTILIDADE DO SOLO E NUTRIÇẢO DE PLANTAS, 23., Caxambu, 1998. FertiBio 98: anais. Lavras: UFLA; SBCS;SBM, 1998. p.830.

MARCHIORI Jr., M.; MELO, W.J. Carbono, carbono da biomassa microbiana e atividade enzimática em um solo sob mata natural, pastagem e cultura do algodoeiro. Revista Brasileira de Ciência do Solo, v. 23, p. 257-263, 1999.

MARISCAL, A.; GARCIA, A.; CARNERO, M. et al. Evaluation of the toxicity of several heavy metals by a fluorescent bacterial bioassay. Journal of Applied Toxicology, v. 15, n. 2, p. 103-107, 1995.

MARSCHNER, $H$. Ion uptake mechanisms of individual cells and roots: short-distance transport. In: MARSCHNER, H Mineral nutrition of higher plants. San Diego: Academic Press, 1995. cap. 2, p. 6-78.

MARTIN, H.W.; KAPLAN, D.I. Temporal changes in cadmium, thallium, and vanadium mobility in soil and phytoavailability under field conditions. Water, Air and Soil Pollution, v. 101, p. 399-410, 1998.

MARTIN, M.H.; COUGHTREY, P.J. Impact of metals on ecosystem function and productivity. In: LEPP, N.W. Effect of heavy metal pollution on plants. London: Applied Science Publ., 1981. v.1, cap. 4, p. 119-158.

MATOS, A.T.; FONTES, M.P.F.; JORDÃO, C.P. et al. Mobilidade e formas de retenção de metais pesados em latossolo vermelho-amarelo. Revista Brasileira de Ciência do Solo, v. 20, n. 3, p. 379-387, 1996.

MATTHEWS, P.J.; Control of metal application rates from sewage utilization in agriculture. CRC Critical Reviews in Environmental Control, v. 14, n. 3, p.199-250, 1984.

MATTIAZZO, M.E. Comportamento de cobre, cádmio, crômio, níquel e zinco adicionados a solos de clima tropical em diferentes valores de pH. Piracicaba, 1994. 197 p. Tese (Livre Docência) - Escola Superior de Agricultura "Luiz de Queiroz", Universidade de São Paulo.

MATTIGOD, S.V.; PAGE, A.L; THORNTON, I. Identification of some trace metal minerals in mine waste contamined soil. Soil Science Society of America Journal, v. 50, p. 254-258, 1986.

MAZUR, N.; SANTOS, G.A; VELLOSO, A.C.X. Efeito do composto de resíduo urbano na disponibilidade de fósforo em solo ácido. Revista Brasileira de Ciência do Solo, v. 7, p. 153-156, 1983a.

MAZUR, N.; VELLOSO, A.C.X.; SANTOS, G. A Efeito do composto de residuo urbano no pH e alumínio trocável em solo ácido. Revista Brasileira de Ciência do Solo, v. 7, p. 157-159, 1983b.

MAZUR, N. Níquel, chumbo, zinco e cobre em solos que receberam composto de resíduos sólidos urbanos. Viçosa. 1997. 129 p. Tese (Doutorado) - Universidade Federal de Viçosa.

McBRIDE, M.B. Reactions controlling heavy metal solubility in soils. Advances in Soil Science, v.10, p. 1-56, 1989.

MCBRIDE, M.B. Toxic metal accumulation from agricultural use of sludge: are USEPA regulations protective ? Journal of Environmental Quality, v. 24, n. 1, p. 5-18, 1995. 
MCBRIDE, M.B.; BLASIAK, J.J. Zinc and copper solubility as a function of $\mathrm{pH}$ in na acid soil. Soil Science Society of America Journal, v. 43, p. 866-870, 1979.

MCBRIDE, M.B.; RICHARDS, B.K. Long-term leaching of trace elements in a heavily sludge-amended sitty clay loam soil. Soil Science, v. 164, n. 9, p. 613-623, 1999.

McBRIDE, M.B.; RICHARDS, B.K.; STEENHUIS, T. et al. Mobility and solubility of toxic metals and nutrients in soil fifteen years after sludge application. Soil Science, v. 162, n. 7, p. 487-500, 1997

McCARTY, G.W. Modes of action of nitrification inhibitors. Biology and Fertility of Soils. v. 29, p. 1-9, 1999.

MCGRATH, S.P. Metal concentrations in sludges and soil from a long term field trial. Journal of Agricultural Science, Cambridge v. 103, p. 25-35, 1984.

McGRATH, S.P. Long-term studies of metal transfers following application of sewage sludge. In: COUGHTREY, P.J.; MARTIN, M.H.; UNSWORTH, M.H. Pollutant transport and fate in ecosystems. Oxford: Blackwell Scientific, 1987. p. 301-317. (British Ecological Society. Special Publication, 6)

McGRATH, S.P. Chromium and nickel. In: ALLOWAY, B.J. Heavy metals in soils. London: Blackie Academic \& Professional, 1995. cap. 7, p. 152-178.

McGRATH, S.P.; CHAUDRI, A.M. Long-term effects of metal contamination on Rhizobium. Soil Biology and Biochemistry. v. 31, p. 1205-1207, 1999.

MCGRATH, S.P.; CUNLIFFE, C.H. A simplified metrod for the extraction of the metals $\mathrm{Fe}, \mathrm{Zn}, \mathrm{Cu}, \mathrm{Ni}, \mathrm{Cd}, \mathrm{Pb}$, $\mathrm{Cr}, \mathrm{Co}$ and $\mathrm{Mn}$ from soils and sewage sludges. Journal of the Science of Food and Agriculture, v. 36, p. $794798,1985$.

MCGRATH, S.P.; LANE, P.W. An explanation for the apparent losses of metals in a long-term field experiment with sewage sludge. Environmental Pollution, v. 60, p. 235-256, 1989.

MCKENNA, I.M.; CHANEY, R.L.; Characterization of a cadmium-zinc complex in lettuce leaves. Biological Trace Element Research, v. 48, p. 13-29, 1995.

MCKENNA, I.M.; CHANEY, R.L; WILLIAMS, F.M. The effects of cadmium and zinc interactions on the accumulation and tissue distribution of zinc and cadmium in lettuce and spinach. Environmental Pollution, v. 79, p. 113-120, 1993.

MCKENNA, I.M.; CHANEY, R.L; TAO, S. et al. Interactions of plant zinc and plant species on the bioavailability of plant cadmium to japanese quail fed lettuce and spinach. Environmental Research, v. 57, p. $73-87,1992$.

MCKENZIE, R.M. The adsorption of lead and other heavy metals on oxides of manganese and iron. Australian Journal of Soil Research, v. 18, p. 61-73, 1980.

MCLAREN, R.G.; CRAWFORD, D.V. Studies on soil copper. I. The fractionation of $\mathrm{Cu}$ in soil. Journal of Soil Science, v. 24, n. 2, p. 172-181, 1973 a.

MCLAREN, R.G.; CRAWFORD, D.V. Studies on soil copper. II. The specific adsorption of copper by soils. Journal of Soil Science, v. 24, n. 4, p. 443-452, 1973 b.

MCLAREN, R.G.; BACKES, C.A.; RATE, A.W. et al. Cadmium and cobalt desorption kinetics from soil clays: effect of sorption period. Soil Science Society of America Journal, v. 62, p. 332-337, 1998.

MCLAUGHLIN, M.J.; MAIER, N.A; RAYMENT, G.E. et al. Cadmium in australian potato tubers and soils. Journal of Environmental Quality, v. 26, p. 1644-1649, 1997. 
MCLAUGHLIN, M.J.; PALMER, L.T.; TILLER, K.G. et al. Increasing soil salinity causes elevated cadmium concentrations in field-grown potato tubers. Journal of Environmental Quality, v. 23, p. 1013-1018, 1994.

MELLO, F.A.F.; BRASIL SOBRINHO, M.O.C.; ARZOLLA, S. et al. Fertilidade do Solo. São Paulo: Nobel, 1989. $400 \mathrm{p}$.

MELLO Jr., R.F. Geoquímica da contaminação industrial do solo e do subsolo por metais pesados na região de Suzano-SP. São Paulo, 1998. 113 p. Dissertaçăo (Mestrado) - Instituto de Geociências, Universidade de São Paulo.

MENCH, M.J. Cadmium availability to plants in relation to major long-term changes in agronomy systems. Agriculture, Ecosystems and Environment, v. 67, p. 175-187, 1998.

MENCH, M.; BAIZE, D.; MOCQUOT, B. Cadmium availability to wheat in five soil series from the Yonne district, Burgundy, France. Environmental Pollution, v. 95, n. 1, p. 93-103, 1997.

MENCK, M.; MARTIN, E. Mobilization of cadmium and other metals from two soils by root exsudates of Zea mays L., Nicotiana tabacum L. and Nicotiana rustica L. Plant and Soil, v. 132, p. 187-196, 1991.

MENEZES, D.B. Diagnóstico dos impactos do lixão de São Carlos no meio físico. São Carlos. 1994. 101 p. Dissertação (Mestrado) - Escola de Engenharia de São Carlos, Universidade de São Paulo.

MERCKX, R.; GINKEL, J.H. van; SINNAEVE, J. et al. Plant-induced changes in the rhizosphere of maize and wheat. II. Complexation of cobalt, zinc and manganese in the rhizosphere of maize and wheat. Plant and Soil, v. 96, p. 95-107, 1986.

MILLER, T.L.; SWAGER, R.R.; WOOD, S.G. et al. Sampling compost sites for metals and pesticides. Resource Recycling, v. 11, n. 12, p. 80,82-87, Dec. 1992.

MILLER, W.P.; MARTENS, D.C.; ZELAZNY, L.W. Effect of sequence in extration of trace metals from soils. Soil Science Society of America Journal, v. 50, p. 598-601, 1986 a.

MILLER, W.P.; MARTENS, D.C.; ZELASNY, LW. et al. Forms of solid phase copper in copper enriched swine manure. Journal of Environmental Quality, v. 15, p. 69-72, 1986 b.

MINER, G.S.; GUTIERREZ, R.; KING, LD. Soil factors affecting plant concentrations of cadmium, copper, and zinc on sludge-amended soils. Journal of Environmental Quality, v. 26, p.989-994, 1997.

MINNICH, M.M.; McBRIDE, M.B.; CHANEY, R.L. Copper activity in soil solution: II Relation to copper accumulation in young snapbeans. Soil Science Society of America Journal, v. 51, p. 573-578, 1987.

MOOLENAAR, S.W.; BELTRAMI, P.; Heavy metals balances of an italian soil as affected by sewage sludge and bordeaux misture applications. Journal of Environmental Quality, v. 27, p. 828-835, 1998.

MORENO, J.L; HERNANDEZ, T; GARCIA, C. Effects of a cadmium-contaminated sewage sludge compost on dynamics of organic matter and microbial activity in an arid soil. Biology and Fertility of Soils, v. 28, p. 230-237, 1999.

MORENO, J.L.; GARCIA, C.; HERNÁNDEZ, T. et al. Application of composted sewage sludges contaminated with heavy metals to an agricultural soil. Effect on lettuce growth. Soil Science and Plant Nutrition, v. 43, n. 3, p. 565-573, 1997.

MORTVEDT, J.J. Cadmium levels in soils and plants from some long-term soil fertility experiments in the United States of America. Journal of Environmental Quality, v. 16, n. 2, p. 137-142, 1987.

MULLA, D.J.; PAGE, A.L; GANJE, T.J. Cadmium accumulation and bioavailability in soils from long-term phosphorus fertilization. Journal of Environmental Quality, v. 9, n. 3, p. 408-412, 1980. 
MURAOKA, T. Avaliação dos teores totais de zinco e manganês do solo. Revista Brasileira de Ciência do Solo, v. 8, p. 155-158, 1984.

NAIDU, R.; KOOKANA, R.S.; SUMNER, M.E. et al. Cadmium sorption and transport in variable charge soils: a review. Journal of Environmental Quality, v. 26, p. 602-617, 1997.

NAKAGAWA, J.; KAMITSUJI, M.K.; PIERI, J.C. et al. Efeitos do bagaço de cana, decomposto por ação de biofertilizantes, na cultura da alface (Lactuca sativa L.). Científica, v. 21, n. 1, p. 169-177, 1993.

NEHRU, B; KAUSHAL, S. Effect of lead on hepatic microsomal enzyme activity. Journal of Applied Toxicology, v. 12, n. 6, p. 401-405, 1992.

NEILSEN, D.; HOYT, P.D.; MACKENZIE, AF. Distribution of soil $\mathrm{Zn}$ fractions in British Columbia interior orchard soils. Canadian Journal of Soil Science, v..66, p.445-454, 1986.

NIELSEN, F.H Chromium. In: SHILS, M.E.; OLSON, J.A.; SHIKE, M. Modern nutrition in health and disease. Baltimore: Williams \& Wilkins, 1994. cap. 14, p. 264-268.

NYAMANGARA, J. Use of sequential extraction to evaluate zinc and copper in a soil amended with sewage sludge and inorganic metal salts. Agriculture, Ecosystems and Environment, v. 69, p. 135-141, 1998.

OBROUCHEVA, N.V.; BYSTROVA, E.I.; IVANOV, V.B. et al. Root growth responses to lead young maize seedlings. Plant and Soil, v. 200, p. 55-61, 1998.

OLIVEIRA, P.C.C. Monitorização da concentração de metais pesados no composto cru obtido a partir de lixo doméstico produzido na usina de compostagem de Vila Leopoldina no municipio de São Paulo. São Paulo, 1995, 105 p. Disssertação (Mestrado). Instituto de Química, Universidade de São Paulo.

OLIVEIRA, J.B.; JACOMINE, P.K.; CAMARGO, M.N. Classes gerais de solos do Brasil: guia auxiliar para seu reconhecimento. Jaboticabal: FUNEP, 1992. 201 p.

OLIVEIRA, M.R.G.; PORTAS, C.A.M. Aspectos fundamentais do sistema radicular e seu papel no desenvolvimento das culturas. In: FERREIRA, M.E.; CASTELLANE, P.D.; CRUZ, M.C.P. Nutrição e adubação de hortaliças. Piracicaba: Associação Brasileira para Pesquisa da Potassa e do Fosfato, 1993. p. 15-35.

ØVREAS, L; TORSVIK, V. Microbial diversity and community structure in two different agricultural soil communities. Microbial Ecology, v. 36, p. 303-315, 1998.

PAGE, AL.; BINGHAM, F.T.; CHANG, A.C. Cadmium. In: LEPP, N.W. Effect of heavy metal pollution on plants. London: Applied Science Publishers, 1981. v. 1: Effects of trace metals on plant function, cap. 3, p. $77-109$.

PARKPAIN, P.; SIRISUKHODOM, S.; CARBONELL-BARRACHINA, A.A. Heavy metals and nutrients chemistry in sewage sludge amended thai soils. Journal of Environment Science Health, v. A33, n.4, p. $573-597,1998$.

PARR, J.F; HORNICK, S.B. Utilization of municipal wastes. In: METTING Jr., F.B. Soil Microbial Ecology - Applications in Agricultural and Environmental Management. Washington: Marcel Dekker, Inc., 1993. Cap. 19. p. 545-594.

PAVAN, M.A;CHAVES,J.C.D; ANDROCIOLI FILHO, A; VIEIRA, M.J. Alteração da agregaçăo do solo em função do manejo em lavouras cafeeiras. Arquivo de Biologia e Tecnologia. v. 38, n. 1, p. 205-215, 1995.

PAVAN, M.A.; VIEIRA, M.J.; ANDROCIOLI FILHO, A. Influência do manejo das plantas daninhas em lavoura cafeeira na capacidade de troca de cátions e cátions trocáveis em solo com cargas variáveis Arquivo de Biologia e Tecnologia. v. 38, n. 1, p. 305-311. 1995. 
PEDRO Jr., M.J.; MELLO, M.H.A; ORTOLANI, A.A. et al. Estimativa das temperaturas médias mensais, das máximas e das minimas para o Estado de São Paulo. Campinas: IAC. 1991.11 p. (IAC. Boletim Técnico, 142)

PEIXOTO, R.T.G. Compostagem: opção para o manejo orgânico do solo. Londrina: IAPAR, 1988.160 p. (IAPAR. Circular, 57)

PEIXOTO,R.T.G.; FRANCO, A.A.; ALMEIDA, D.L. Efeito do lixo urbano compostado com fosfato natural na nodulaçào e crescimento do feijoeiro. Pesqisa Agropecuária Brasileira, v. 22, n.11/12, p. 1117-1132, nov./dez. 1987.

PEIXOTO, R.T.G.; ALMEIDA, D.L.; FRANCO, A.A. Adiçäo de fosfatos à compostagem de lixo urbano e disponibilidade de fósforo residual em sorgo forrageiro. Pesqisa Agropecuária Brasileira, v. 24, n. 5, p. $587-592$, maio $1989 a$.

PEIXOTO, R.T.G.; ALMEIDA, D.L.; FRANCO, A.A. Compostagem de lixo urbano enriquecido com fontes de fósforo. Pesquisa Agropecuária Brasileira, v. 24, n. 5, p. 599-606, maio 1989b.

PEREIRA NETO, J.T. Um sistema de reciclagem e compostagem de lixo urbano de baixo custo, para países em desenvolvimento. Informe Técnico. Conselho de Extensão da Universidade Federal de Viçosa, v.16, n.74, p. 1-16, 1995.

PEREIRA NETO, J.T; STENTIFORD, E.l. Aspectos epidemiológicos na compostagem. In: CONGRESSO BRASILEIRO DE ENGENHARIA SANITÁRIA, 16., Goiânia, 1991. Anais. Goiânia: 1991.

PETRUZZELLI, G.; LUBRANO, L; GUIDI, G. Heavy metal extractability. Biocycle, v.26, p. 46-48, Nov./Dec. 1985.

PEVERLY, J.H.; GATES, P.B. Utilization of municipal solid waste and sludge composts in crop production systems. In: CLAPP, C.E.; LARSON, W.E; DOWDY, R. H.; Sewage sludge: land utilization and the environment. Madison: SSSA, 1994. cap. 26, p. 193-203.

PHIPPS, D.A. Chemistry and biochemistry of trace metals in biological systems. In: LEPP, N.W. Effect of heavy metal pollution on plants. London: Applied Science Publ., 1981. v. 1: Effects of trace metals on plant function, cap. 1, p. 1-54.

PIERZYNSKI, G.M; SIMS, J.T; VANCE, G.F. Soils and environmental quality. Boca Raton: Lewis Publ., 1994. $313 p$.

PINAMONTI, F; ZORZI, G; GASPERI, F. et al. Growth and nutrient status of apple trees and grapevines in municipal solid waste amended soil. Acta Horticulturae, n. 383, p. 313-321, 1995.

POLPRASERT, C. Organic waste recycling. Chichester: John Wiley \& Sons, 1989, 357 p.

POULIK, Z. Influence of nickel contaminated soils on lettuce and tomatoes. Scientia Horticulturae, v. 81, p. $243-250,1999$.

PRESSINOTI, Q.S.H.C.; FERNANDES JR., V. Caracterização físico-química de composto orgânico proveniente de 13 usinas de compostagem do estado de São Paulo. (compact disc) In: CONGRESSO BRASILEIRO DE GEOQUÍMICA, 5; CONGRESSO DE GEOQUIMIICA DE PAISES DE LINGUA PORTUGUESA, 3., Niterói, 1995. Trabalhos. Niterói: SBG, 1995.

PRADO FILHO, J.F. Efeito da incorporação do composto de lixo domiciliar urbano sobre algumas características químicas e microbiológicas do solo e sua influência nas perdas de solo água e nitrogênio por escorrimento superficial. Santa Cruz do Sul: Faculdades Integradas de Santa Cruz do Sul, 1986. p. 45-154.

PRADO FILHO, L.G. do; CANTARELLI, P.R. Avaliação do conteúdo de chumbo, cádmio e mercúrio em extratos de tomate. Ciência e Tecnologia de Alimentos, v. 4, n. 1, p.79-85, 1984. 
PRATA, F.; HIKISHIMA, M.; SANTOS FILHO, A. et al. Influência da matéria orgância na capacidade de troca de cátions em solos do Estado do Paraná. Agrárias, v. 15, n. 2, p. 69-74, 1996.

PRINCE, J. Separation strategies: effect on the quality of recyclables and compost. Resource Recycling, V.11, n.7, p. 70, 72-78, July 1992.

PURVES, D; MACKENZIE, E.J. Effects of applications of municipal compost on uptake of copper, zinc and boron by garden vegetables. Plant and Soil, $\quad$ v. 39, p. 361-371, 1973.

PURVES, D.; MACKENZIE, E.J. Phytotoxicity due to boron in municipal compost. Plant and Soil, v. 40, p. 231-235, 1974.

RAlJ, B. van. A capacidade de troca de cátions das fraçōes orgânicas e mineral em solos. Piracicaba. 1967. 67p. Tese (Doutorado). - Escola Superior de Agricultura "Luiz de Queiroz", Universidade de São Paulo.

RAIJ, B. van.; QUAGGIO, J.A. Métodos de análise de solo para fins de fertilidade. Campinas: IAC, 1983. 31 p. (IAC. Boletim Técnico, 81).

RAIJ, B. van; CANTARELLA, H.; QUAGGIO, J.A. et al. Recomendações de adubação e calagem para o Estado de São Paulo. Campinas: IAC, 1996. 285 p.

RAVEN, K.P.; LOEPPERT, R.H. Trace elements composition of fertilizers and soil amendments. Journal of Environmental Quality, v. 26, p. 551-557, 1997.

RAVEN, K.P.; REYNOLDS, J.W.; LOEPPERT, R.H. Trace element analyses of fertilizers and soil amendments by axial-view inductively-coupled plasma atomic emission spectrophotometry. Communications in Soil Science and Plant Analysis, v. 28, n. 3/5, p. 237-257, 1997.

REAVES, G.A; BERROW, M.L. Total copper contents of Scottish soils. The Journal of Soil Science, V. 35, n. 4, p. 583-592, 1984.

REIMANN, D.O. Heavy metals in domestic refuse and their distribution in incinerator residues. Waste Management \& Research, v. 7, p. 57-62, 1989.

REISENAUER, H.M. Determination of plant-available soil manganese. In: GRAHAM, R.D.; HANNAM, R.J.; UREN, N.C. Manganese in soils and plants. Dordrecht: Kluwer Academic, 1988. cap. 6, p.87-100.

RICCI, M.S.F.; CASALI, V.W.D.; CARDOSO, A.A. et al. Teores de nutrientes em duas cultivares de alface adubadas com composto orgânico. Pesquisa Agropecuária Brasileira, v. 30, n. 8, p. 1035-1039, ago. 1995.

RIVERO, C. Efecto de la incorporación de residuos orgánicos sobre algunas propiedades de un alfisol degradado en el estado Yaracuy, Venezuela (compact disc). In: CONGRESSO LATINO AMERICANO DE SUELO, 13., Águas de Lindóia, 1996. Solo-suelo 96: trabalhos. Piracicaba: SBCS; SLCS, 1996.

ROANE, T.M. Lead resistance in two bacterial isolates from heavy metal-contaminated soils. Microbial Ecology. v. 37, p. 218-224, 1999.

ROBARDS, K.; WORSFOLD, P. Cadmium: toxicology and analysis. Analyst, v. 116, p. 549-568, 1991.

RÖMKENS, P.F.A.M.; SALOMONS, W. Cd, Cu and $\mathrm{Zn}$ solubility in arable and forest soils: consequences of land use changes for metal mobility and risk assessment. Soil Science, v. 163, n. 11, p. 859-871, 1998.

RÖMKENS, P.F.A.M.; HOENDERBOOM, G.; DOLFING, J. Copper solution geochemistry in arable soils: field observations and model application. Journal of Environmental Quality, v. 28, p. 776-783, 1999. 
ROOSEMALEN, G.R.E.M. van; LUSTENHOUWER, J.W.A.; OOSTHOEK, J. et al. Heavy metal sources and contamination mechanisms in compost production. Resources \& Conservation, v. 14, p. 321$334,1987$.

ROSS, S.M. Toxic metals in soil-plant systems. Bristol: John Wiley, 1994a. cap. 1, p. 3-25: Sources and forms of potentially toxic metals in soil plant systems.

ROSS, S.M. Toxic metals in soil-plant systems. Bristol: John Wiley, 1994b. cap. 5, p. 189-244: Toxic metals: fate and distribution in contaminated ecosystems.

ROSS, S.M.; KAYE, K.J. The meaning of metal toxicity in soil plant systems. In: ROSS, S.M. Toxic metals in soil-plant systems. 1.ed. Bristol: John Wiley \& Sons Ltd, 1994. Cap. 2. p. 27-61.

ROSSEAUX, P.D.; NAVARRO, A.; VERMANDE, P. Heavy metal distribution in household waste. Biocycle, V. 30, p. 81-84, Sept. 1989.

ROSSEAUX, P.D.; CASTILHOS Jr., A.B.; VERMANDE, P. et al. Determination of trommel meshes for optimal separation of compost fraction of municipal solid waste from Florianópolis, Sc, Brazil. Resources, Conservation \& Recycling, v. ????, p. 217-229, 1992.

ROSTON, J.J.; KIMOTO, T. Efeito da adição de sulfato de cobre na produção de alface em solo turfoso. Horticultura Brasileira, v. 5, n. 1, p. 88, 1987.

ROVERS, H; CAMARGO, O.A.; VALADARES, J.M.A.S. Níquel total e solúvel em DTPA em solos do estado de São Paulo. Revista Brasileira de Ciência do Solo, v. 7, p. 217-220, 1983.

SADOVNIKOVA, L.K.; ZYRIN, N. G. Indices of soil pollution by heavy metals and non metals used for soil monitoring. Soviet Soil Science, v. 17, n. 6, p. 58-63, 1986.

SALOMONS, W. Adoption of common schemes for simgle as sequential extrations of trace metal in soil and in sediments. . Inter. J. Environ. Anal. Chem. v. 51, p. 3-4, 1993.

SANTOS, C.E.R.S.; STAMFORD, N.P.; SANTOS, D.R. Efeito do composto do lixo urbano suplementado com fósforo e da inoculação com Bradyrhizobium em caupi. Revista Brasileira de Ciência do Solo, $v$. 16, p. 25-30, 1992.

SANTOS, I.C. Conteúdo de metais pesados, potássio e sódio e produçăo de cultivares de alface adubados com composto orgânico de lixo urbano. Viçosa, 1995. 89 p. Dissertaçăo (Mestrado) - Universidade Federal de Viçosa.

SANTOS FILHO, A. Capacidade de troca de cátions das fraçōes orgânica e mineral em solos do Estado do Paraná. Revista do Setor de Ciências Agrárias, v. 5, p. 69-74, 1985.

SARRUGE, J.R.; HAAG, H.P. Análises químicas em plantas. Piracicaba: ESALQ, Departamento de Química, 1974. 56 p.

SAUBERBECK, D. The environmental significance of the cadmium content in phosphorus fertilizer. Plant Research and Development, v. 19, p. 24-34, 1984.

SAUBERBECK, D. Plant element and soil properties governing uptake and availability of heavy metals derived from sewage sludge. Water, Air and Soil Pollution, v. 57/58, p. 227-237, 1991.

SAUBERBECK, D.; HEIN, A. The nickel uptake from different soils and its prediction by chemical extractions. Water, Air and Soil Pollution, v. 57/58, p. 861-871, 1991.

SCHALSCHA, E.B.; ESCUDERO, P.; SALGADO, P. et al. Chemical forms and sorption of copper and zinc in soils of Central Chile. Communications in Soil Science and Plant Analysis, v.30, n.3/4, p. $497-507,1999$. 
SCHALSCHA, E.B.; MORALES, M.; AHUMADA, I; SHIRADO, T.; PRATT, P.F.; Fractionation of Zn, $\mathrm{Cr}, \mathrm{Kr}$, and $\mathrm{Ni}$ in waste water solids and soil. Agrochimica. v. 24, p. 361-368, 1980.

SCHALSHA, E.B.; MORALES, M.; VERGARA, I. et al. Chemical fractionation of heavy metals in waste water affected soils. Journal Water Pollution Control Federation, v. 54, p. 175-180, 1982.

SCHEINBERG, A.; SMOLER, D. European food waste collection and composting programs. Resource Recycling, v. 9, n.12, p. 76-81, Dec. 1990.

SCHULZ, R.; RÖMHELD, V. Recycling of municipal and industrial organic wastes in agriculture: benefits, limitations, and means of improvement. Soil Science and Plant Nutrition, v. 43, p. 1051-1056, 1997.

SERNA, M.D.; POMARES, F. Indexes of assessing $N$ availability in sewage sludges. Plant and Soil, v. 139, p. 15-21, 1992.

SEYBOLD, C.A.; HERRICK, J.E.; BREJDA, J.J. Soil resilience: a fundamental component of soil quality. Soil Science, v. 164, n. 4, p. 225-234, 1999.

SHEAFFER, C.C.; DECKER, A.M.; CHANEY, R.L. et al. Soil temperature and sewage sludge effects on metals in crop tissues and soils. Journal of Environmental Quality, v. 8, n. 4, p. 455-459, 1979.

SHUMAN, L.M. Zn adsorption isotherms for soil clays with and without iron oxides removed. Soil Science Society of America Journal, v. 40, p. 349-352, 1976.

SHUMAN, L.M. Adsorption of $\mathrm{Zn}$ by Fe and Al hydrous oxides as influenced by aging and $\mathrm{pH}$. Soil Science Society of America Journal, v. 41, p. 703-706, 1977.

SHUMAN, L.M. Zinc, manganese, and copper in soil fractions. Soil Science, v. 127, n. 1, p. 10-17, 1979.

SHUMAN, L.M. Effect of liming on the distribution of manganese, copper, iron, and zinc among soil fractions. Soil Science Society of America Journal, v. 50, p. 1236-1240, 1986.

SHUMAN, L.M. Effect of phosphorus level on extractable micronutrients and their distribution among soil fractions. Soil Science Society of America Journal, v.52, p.136-141, 1988.

SHUMAN, L.M. Effect of organic waste amendments on cadmium and lead in soil fractions of two soils. Communications in Soil Science and Plant Analysis, v. 29, n. 19/20, p. 2939-2952, 1998.

SHUMAN, L.M Effect of organic waste amendments on zinc adsorption by two soils. Soil Science, v. 164, n. 3, p. $197-205,1999$ a.

SHUMAN, LM Organic waste amendments effect on zinc fractions of two soils. Journal of Environmental Quality, v. 28, p.1442-1447, 1999b.

SHUMAN, L.M. HARGROVE, W.L. Effect of tillage on the distribution of manganese, copper, iron and zinc in soil fractions. Soil Science Society of America Journal, v. 49, p. 1117-1121, 1985.

SHUMAN, L.M.; WANG, J. Effect of rice variety on zinc, cadmium, iron, and manganese content in rhizosphere and non-rhizosphere soil fractions. Communications in Soil Science and Plant Analysis, v. 28, n. 1/2, p. 23-26, 1997.

SIGOLO, J.B.; ASSUNÇÃO, J.C.B. Concentração e dispersão de metais pesados associados a rejeitos urbanos da ETE-Barueri-SP. (compact disc) In: CONGRESSO BRASILEIRO DE GEOQUÍMICA 5.; CONGRESSO DE GEOQUIIMICA DE PAISES DE LINGUA PORTUGUESA, 3., Niterói, 1995. Trabalhos. Niterói: SBG, 1995.

SIGOLO, J.B.; MELLO JR. R.F. Comportamento geoquímico de metais pesados no meio não saturado. Um exemplo. (compact disc) In: CONGRESSO BRASILEIRO DE GEOQUÍMICA, 5.; CONGRESSO DE GEOQUIMICA DE PAISES DE LINGUA PORTUGUESA, 3., Niterói, 1995. Trabalhos. Niterói: SBG, 1995. 
SIMEK, M.; HOPKINS, D.W.; KALCIK, J. et al. Biological and chemical properties of arable soils affected by long-term organic and inorganic fertilizer applications. . Biology and Fertility of Solls, v. 29, p. 300$308,1999$.

SIMS, J.T. Soil pH effects on the distribution and plant availability of manganese, copper, and zinc. Soil Science Society of America Journal, v. 50, p. 367-373, 1986.

SIMS, J.T; KLINE, J.S. Chemical fractionation and uptake of heavy metals in soils amended with cocomposted sewage sludge. Journal of Environmental Quality, v.20, p. 387-395, 1991.

SIMS, J.L.; PATRICK Jr, W.H. The distribution of micronutrient cations in soil under conditions of varying redox potential and pH. Soil Science Society of America Proceedings, v. 42, p, 258-262, 1978.

SINHA, M.K. Effect of straw application on yield and phosphorus nutrition of crops. Plant and Soil, v. 43, n. 3, p. 537-545, 1975.

SOON, Y.K.; BATES, T.E. Chemicals pools of $\mathrm{Cd}, \mathrm{Ni}$, and $\mathrm{Zn}$ in polluted soils and some preliminary indications of theirs availability to plants. Journal of Soil Science, v. 33, p. 477-488, 1982.

SIQUEIRA, J.O.; FRANCO, A.A. Biotecnologia do solo: fundamentos e perspectivas. Brasília: MEC; ABEAS; Lavras: ESAL, FAEPE, 1988. 235 p.

SMITH, K.A; PATERSON, J.E. Manganese and cobalt. In: ALLOWAY, B.J. Heavy metals in soils. London: Blackie Academic \& Professional, 1995. cap. 10, p. 224-244.

SPIERS, T.M.; FRANCIS, G.S.; CANT, G. The contribution of organic wastes to nitrate leaching losses from vegetable soils in New Zealand. In: INTERNATIONAL CONFERENCE, CONTAMINANTS \& THE SOIL ENVIRONMENT AUSTRALASIA-PACIFIC, Adelaide, 1996. p. 103-104.

SPOSITO, G.; LUND, LJ.; CHANG, A.C. Trace metal chemistry in arid-zone field soil amended with sewage sludge: I. Fractionation of $\mathrm{Ni}, \mathrm{Cu}, \mathrm{Zn}, \mathrm{Cd}$ and $\mathrm{Pb}$ in Solid Phases. Soil Science Society of America Journal, v. 46, p. 260-264, 1982.

STERRETT, S.B.; CHANEY, R.L.; GIFFORD, C.H. et al. Influence of fertilizer and sewage sludge compost on yield and heavy metals accumulation by lettuce grown in urban soils. Envrionmental Geochemistry and Health, v. 18, p. 135-142, 1996.

STRATTON, M.L; BARKER, A.V.; RECHCIGL, J.E. Compost. In: RECHCIGL, J.E. Soils amendments and environmental quality, Boca Raton: Lewis Publ., 1995. cap. 7, p.249-310.

STEVENSON, F.J. Humus chemistry. New York: John Wiley, 1982. 443 p.

STREET, J.J.; SABEY, B.R.; LINDSAY, W.L. Influence of pH, phosphorus, cadmium, sewage sludge, and incubation time on the solubility and plant uptake of cadmium. Journal of Environmental Quality, $\vee .7$, n. 2 , p. $286-290,1978$.

STUPAR, J.; VRTOVEC, M.; KOCIJANCIC, A. et al. Chromium status of tannery workers in relation to metabolic disorders. Journal of Applied Toxicology, v. 19, p. 437-446, 1999.

TACK, F.M.G.; SINGH, S.P.; VERLOO, M.G. Leaching behaviour of $\mathrm{Cd}, \mathrm{Cu}, \mathrm{Pb}$ and $\mathrm{Zn}$ in surface soils derived from dredged sediments. Environmental Pollution, v. 106, p. 107-114, 1999.

TAN, K.H. Principles of soil chemistry. New York: Marcel Dekker, 1993. 362 p.

TAVARES, T.M.; CARVALHO, F.M. Avaliação da exposição de populações humanas a metais pesados no ambiente: exemplos do Recôncavo Baiano. Química Nova, v. 15, n. 2, p. 147-153, 1992.

TAYLOR, P. Heavy metals criteria for compost. Resource Recycling, v. $10, \quad$ n. 9, p. $68,70,72,74,76$, 78, 80, 1991. 
TAYLOR, P. The first year with wet/dry composting: a report from the field. Resource Recycling, $v .12$, n. 1, p. 34,36-43, Jan. 1993.

TEMMINGHOFF, E.J.M; DER ZEE, S.E.A.T.M. van; HAAN, F.A.M. Copper mobility in a coppercontaminated sandy soil as affected by $\mathrm{pH}$ and solid and dissolved organic matter. Environmental Science and Technology, v. 31, p.1109-1115, 1997.

TESSIER, A. CAMPBELL, P.G.C.; BISSON, M. Sequential extractition procedure for the speciation of particulate trace metals. Analytical Chemistry, v. 51, n. 7, p. 844-851, 1979.

THOMPSON, K.C.; WAGSTAFF, K. Simplified method for the determination of cadmium, chromium, copper, nickel, lead and zinc in sewage sludge using atomic absorption spectrometry. Analyst, v. 105, p. 883-896, 1980.

THOMSON, C.J.; MARSCHNER, H.; RÖMHELD, V. Effect of nitrogen fertilizer form on pH of the bulk soil and rhizosphere, and on the growth, phosphorus, and micronutrient uptake of bean. Journal of Plant Nutrition, v. 16, n. 3, p. $493-506,1993$.

THORNTON, I. Geochemical aspects of the distribution and forms of heavy metals in soils. In: LEPP, N.W. Effect of heavy metal pollution on plants. London: Applied Science Publ., 1981. v. 2: Metals in the environment, cap. 1, p. 1-33.

TILLER, K.G. Heavy metals in soils and their environmental significance. Advances in Soil Science, v. 9 , p. 113-142, 1989.

TRANI, P.E. Emprego de superfosfato simples com esterco. Campinas: CATI, 1981. 5 p. (CATI. Instrução Prática).

TYLER, G.; PAHLSSON, M.B.; BAATH, B.E. et al. Heavy-metal ecology of terrestrial plants, microorganisms and invertebrates. A review. Water, Air, and Soil Pollution, v. 47, p. 189-215, 1989.

UEHARA, G; GILLMAN, G. The mineralogy, chemistry, and physics of tropical soils with variable charge clays. Boulder: Westview Press, 1981. $170 \mathrm{p}$.

URE, A.; QUEVAUVILLER, P.H.; MUNTAU, H.; GRIEPINK, B. Speciation of heavy metals in soils and sediments, na account of the improvement and harmonization of extraction techniques undertaken under the auspices of the BCR of the Commission of the European Communities. Internacional Journal of Environment Analytical Chemitry v. 51, p. 135-151, 1993.

URE, A.M. Methods of analysis for heavy metals in soils. In: ALLOWAY, B.J. Heavy metals in soils. London: Blackie Academic \& Professional, 1995. cap. 4. p. 58-102.

UREN, N. C. Form, reactions, and availability of nickel in soils. Advances in Agronomy, v. 48, p. $141-203,1992$.

VALADARES, J.M.A.S. Cobre em solos do Estado de São Paulo. 1 - Cobre total. Bragantia, v. 34, n. 4, p. 125-132, 1975.

VALADARES, J.M.A.S.; CATANI, R.A. Zinco em solos do Estado de São Paulo. I - Zinco total. Bragantia. v. 34, n. 4 , p. $133-139,1975$.

VALDARES, J.M.A.S.; GAL, M.; MINGELGRIN, U. et al. Some heavy metals in solils treated with sewage sludge, their effects on yield, and their uptake by plants. Journal of Environmental Quality, v. 12, n. 1 , p. 49-57, 1983.

VANCE, E.D.; BROOKES, P.C.; JENKINSON, D.S. An extraction method for measuring soil microbial biomass C. Soil Biology and Biochemistry. v. 19, n. 6, p. 703-707, 1987. 
VERDADE, F.C. Influência da matéria orgânica na capacidade de troca de cátions do solo. Bragantia, V. 15, p. $35-42,1956$.

VIDOR, C.; CAMARGO, F.A.O.; KROB, A.J.D. et al. Avaliação da população microbiana de solos submetidos a aplicação contínua de lixo urbano. (compact disc) In: CONGRESSO BRASILEIRO DE CIÊNCIA DO SOLO, 26., Rio de Janeiro. 1997. Trabalhos. Rio de Janeiro: SBCS, 1997.

VYSKOCIL, A.; VIAU, C. Assessment of molybdenum toxicity in humans. Journal of Applied Toxicology, v. 19, p. $185-192,1999$.

WARDEN, B.T. REISENAUER, H.M. Fractionation of soil manganese forms important to plant availability. Soils Science Society of America, 55, p. 345-349, 1991.

WARMAN, P.R.; MUIZELAAR, T.; TERMEER, W.C. Bioavailability of As, $\mathrm{Cd}, \mathrm{Co}, \mathrm{Cr}, \mathrm{Cu}, \mathrm{Hg}, \mathrm{Mo}, \mathrm{Ni}, \mathrm{Pb}$, Se and $\mathrm{Zn}$ from biosolids amended compost. Compost Science \& Utilization, v. 3., n. 4, p. 40-50, 1995.

WATSON, T. Food waste composting institutions get a taste. Resourse Recycling, v.9, n. 11, p. 45-47, Nov. 1990.

WEBBER, J. Trace metals in agriculture. In: LEPP, N.W. Effect of heavy metal pollution on plants. London: Applied Science, 1981. v. 2: Metals in the environment, cap. 5, p. 159-184.

WENZEL, W.W.; JOCKWER, F. Accumulation of heavy metals in plants grown on mineralised soils of the austrian alps. Environmental Pollution, v. 104, p. 145-155, 1999.

WERNER, W. WARNUSZ, J. Ecological evaluation of long-term application of sewage sludges according to the legislative permissions. Soil Science and Plant Nutrition, v. 43, p. 1047-1049, 1997.

WIERZBICKA, M. Comparison of lead tolerance in Allium cepa with other plant species. Environmental Pollution, v. 104, p. 41-52, 1999.

WILKE, B.M. Effect of single and successive additions of cadmium, nickel and zinc on carbon dioxide evolution and dehydrogenase activity in a sandy luvisol. Biology and Fertility of Soils, v. 11, p. 34-37, 1991.

WILKENS, B.J.; BRUMMEL, N.; LOCH, J.P.G. Influence of pH and zinc concentration on cadmium sorption in acid, sandy soils. Water, Air and Soil Pollution, v. 101, p. 349-362, 1998.

WILLIAMS, C.H.; DAVID, D.J. The effect of superphosphate on the cadmium content of soil and plants. Australian Journal of Soil Research, v. 11, p. 43-56, 1973.

WILLIAMS, T.O.; EPSTEIN, E. Are there markets for compost? Waste Age, v. 22, n. 4, p. 94-95, 98, 100, Apr. 1991.

WORLD HEALTH ORGANIZATION. Trace element in human nutrition and health. Geneva: IAEA, 1996. $343 p$.

WU, J.; LAIRD, D.A.; THOMPSON, M.L. Sorption and desorption of copper on soil clay components. Journal of Environmental Quality, v.28, n.1, p. 334-338, 1999.

XIAN, X. Effect of chemical forms of cadmium, zinc and lead in polluted soil on their uptake by cabbage plants. Plant and Soil, v. 113, p. 257-264, 1989.

XIAN, X.; SHOKOHIFARD, G. Effect of pH on chemical forms and plant availability of cadmium, zinc, and lead in polluted soils. Water, Air and Soil Pollution, v. 45, p. 265-273, 1989.

XUE, Q.; HARRISON, H.C. Effect of soil zinc, $\mathrm{pH}$, and cultivar on cadmium uptake in life lettuce (Lactuca sativa L. var. crispa). Communications in Soil Science and Plant Analysis, v. 22, p. 975-991, 1991. 
YEATES, G.W. Impact of pasture contamination by copper, chromium, and arsenic timber preservative on soil biological activity. Biology and Fertility of Soils. v. 18, p. 200-208, 1994.

ZHANG, M.; ALVA, A.K.; LI, Y.C.; CALVERT, D.V. Chemical asscociation of $\mathrm{Cu}, \mathrm{Zn}, \mathrm{Mn}$, and $\mathrm{Pb}$ in selected sandy citrus soils. Soils Science, v. 162, n. 3, p. 181-188, 1997.

ZHU, B; ALVA, A.K Comparison of single and sequential soil extractions for predicting copper phytotoxicith. Communications in Soil Science and Plant Analysis, v. 24, p. 475-486, 1993. 


\section{APÊNDICE}


Tabela A1. Biomassa microbiana da camada superficial $(0-30 \mathrm{~cm})$ do solo glei húmico determinada por fumigação-extração

\begin{tabular}{c|c|c|c}
\hline \hline amostras & $\mathrm{ug} \mathrm{C} \mathrm{g}^{-1}$ solo & amostras & $\mathrm{ug} \mathrm{C} \mathrm{g}^{-1}$ solo \\
\hline \multirow{2}{*}{ área não } & 36,40 & área & 39,43 \\
cultivada & 33,22 & cultivada & 39,39 \\
propriedade & 36,22 & propriedade & 38,40 \\
1 & 38,03 & 1 & 38,87 \\
\hline média & 35,97 & média & 39,02 \\
\hline desvio padrão & 2,00 & desvio padrão & 0,49 \\
\hline \hline & 41,93 & & 40,64 \\
propriedade & 41,23 & propriedade & 41,82 \\
2 & 37,14 & 3 & 39,90 \\
& 39,35 & & 40,27 \\
\hline média & 39,91 & média & 40,66 \\
\hline desvio padrão & 2,14 & desvio padrão & 0,83 \\
\hline \hline
\end{tabular}


Tabela A2. Número mais provável de microrganismos nas amostras da camada superficial $(0-30 \mathrm{~cm})$ do solo glei húmico da segunda etapa, para 5 repetições.

\begin{tabular}{|c|c|c|c|c|}
\hline amostras / datas de coleta & 14/Set & $01 /$ Out & 14/Set & 01/Out \\
\hline \multirow{4}{*}{ não cultivado } & 50000 & 7000 & 5000 & 50000 \\
\hline & 7500 & 5000 & 13000 & 35000 \\
\hline & 5000 & 8000 & 30000 & 25000 \\
\hline & 8000 & 11000 & 25000 & 80000 \\
\hline média & 17625 & 7750 & 27500 & 47500 \\
\hline desvio padrão & 21623 & 2500 & 3536 & 23979 \\
\hline \multirow{4}{*}{ propriedade 1} & 4500 & 5000 & 600000 & 600000 \\
\hline & 8000 & 2500 & 350000 & 600000 \\
\hline & 8000 & 4500 & 350000 & 600000 \\
\hline & 3500 & 35000 & 130000 & 350000 \\
\hline média & 6000 & 11750 & 357500 & 537500 \\
\hline desvio padrão & 2345 & 15538 & 192072 & 125000 \\
\hline \multirow{4}{*}{ propriedade 2} & 45000 & 5000 & 70000 & 350000 \\
\hline & 8000 & 3500 & 130000 & 80000 \\
\hline & 50000 & 14000 & 140000 & 900000 \\
\hline & 50000 & 17000 & 130000 & 250000 \\
\hline média & 38250 & 9875 & 117500 & 395000 \\
\hline desvio padrão & 20304 & 6638 & 32016 & 354636 \\
\hline \multirow{4}{*}{ propriedade 3} & 1300 & 3500 & 35000 & 70000 \\
\hline & 11000 & 3500 & 170000 & 600000 \\
\hline & 4500 & 1700 & 50000 & 300000 \\
\hline & 8000 & 1100 & 170000 & 35000 \\
\hline média & 6200 & 2450 & 106250 & 251250 \\
\hline desvio padrão & 4210 & 1237 & 73866 & 260524 \\
\hline
\end{tabular}


Tabela A3. Densidade Aparente da camada superficial $(0-30 \mathrm{~cm})$ do solo glei húmico (amostras coletadas na $2^{a}$ etapa).

\begin{tabular}{c|c|c|c}
\hline \hline amostras & $\mathrm{g} \mathrm{cm}^{-3}$ & amostras & $\mathrm{g} \mathrm{cm}^{-3}$ \\
\hline \multirow{2}{*}{ área não } & 0,57 & & 0,73 \\
cultivada & 1,00 & propriedade & 0,63 \\
propriedade & 0,61 & 2 & 0,73 \\
1 & 0,73 & & 0,62 \\
\hline média & 0,73 & média & 0,68 \\
\hline desvio padrão & 0,19 & desvio padrão & 0,06 \\
\hline & 0,73 & & 0,54 \\
propriedade & 0,71 & propriedade & 0,59 \\
1 & 0,77 & 3 & 0,65 \\
& 0,65 & & 0,60 \\
\hline média & 0,72 & média & 0,60 \\
\hline desvio padrão & 0,05 & desvio padrão & 0,05 \\
\hline \hline
\end{tabular}


Tabela A4: Condutividade elétrica da camada superficial $(0-30 \mathrm{~cm})$ do solo glei húmico ( $1^{\mathrm{a}}$ e $2^{\mathrm{a}}$ etapa) e do solo podzólico vermelho-amarelo.

\begin{tabular}{|c|c|c|c|c|c|}
\hline amostras & mmhos $\mathrm{cm}^{-1}$ & amostras & mmhos $\mathrm{cm}^{-}$ & amostras & mmhos $\mathrm{cm}^{-1}$ \\
\hline \multirow{6}{*}{$\begin{array}{l}\text { solo glei } \\
\quad \text { não } \\
\text { cultivado } \\
\text { proprieda } \\
\text { de } 1\left(1^{\text {a }}\right)\end{array}$} & 0,19 & \multirow{4}{*}{\begin{tabular}{|} 
solo glei \\
não \\
cultivado \\
propriedade \\
$1\left(2^{2}\right)$
\end{tabular}} & 0,19 & \multirow{6}{*}{$\begin{array}{c}\text { solo } \\
\text { podzólico } \\
\text { não } \\
\text { cultivado }\end{array}$} & 0,12 \\
\hline & 0,19 & & 0,19 & & 0,16 \\
\hline & 0,19 & & 0,19 & & 0,16 \\
\hline & 0,19 & & 0,19 & & 0,26 \\
\hline & 0,19 & média & 0,19 & & 0,20 \\
\hline & 0,22 & desvio padráo & 0,00 & & 0,19 \\
\hline média & 0.18 & \multirow{4}{*}{$\begin{array}{c}\text { solo glei } \\
\text { propriedade } \\
1\left(2^{a}\right)\end{array}$} & 0,74 & média: & 0,18 \\
\hline desvio padriso & 0,01 & & 0,60 & desulo padráo & 0,05 \\
\hline \multirow{6}{*}{$\begin{array}{c}\text { solo glei } \\
\text { coletado } \\
\text { no plantio } \\
\text { da alface } \\
\left(1^{a}\right)\end{array}$} & 0,68 & & 0,57 & \multirow{6}{*}{$\begin{array}{c}\text { solo } \\
\text { podzólico } \\
\text { coletado } \\
\text { no plantio } \\
\text { da alface }\end{array}$} & 0,62 \\
\hline & 1,28 & & 0,51 & & 0,61 \\
\hline & 0,74 & média & 0,60 & & 0,65 \\
\hline & 0,74 & desvio padras & 0,10 & & 0,65 \\
\hline & 0,83 & \multirow{4}{*}{$\mid \begin{array}{c}\text { solo glei } \\
\text { propriedade } \\
2\left(2^{a}\right)\end{array}$} & 1,41 & & 0,60 \\
\hline & 0,78 & & 1,43 & & 0,59 \\
\hline média & 0,67 & & 1,37 & médta & 0,62 \\
\hline destio padrá & 0.22 & & 1,15 & desvio pacráo & 0,02 \\
\hline \multirow{6}{*}{$\begin{array}{c}\text { solo glei } \\
\text { coletado } \\
\text { na } \\
\text { colheita } \\
\text { da alface } \\
\left(1^{a}\right)\end{array}$} & 0,96 & média & 1,34 & \multirow{6}{*}{$\begin{array}{c}\text { solo } \\
\text { podzólico } \\
\text { coletado } \\
\text { na colheita } \\
\text { da alface }\end{array}$} & 1,18 \\
\hline & 0,67 & desvio padräo & 0,13 & & 1,16 \\
\hline & 1,09 & \multirow{4}{*}{$\mid \begin{array}{c}\text { solo glei } \\
\text { propriedade } \\
3\left(2^{a}\right)\end{array}$} & 0,17 & & 0,77 \\
\hline & 0,97 & & 0,72 & & 0,79 \\
\hline & 0,98 & & 0,64 & & 0,93 \\
\hline & 0,54 & & 0,53 & & 0,94 \\
\hline media & 079 & média & 0,57 & média & 0,96 \\
\hline \multirow[t]{9}{*}{ desvio padia } & 0,21 & desvio pactáo. & 0,24 & desvio padráo & 0,18 \\
\hline & & & & \multirow{6}{*}{$\begin{array}{c}\text { coletado } \\
\text { na colheita } \\
\text { da } \\
\text { beterraba }\end{array}$} & 0,56 \\
\hline & & & & & 0,53 \\
\hline & & & & & 0,50 \\
\hline & & & & & 0,50 \\
\hline & & & & & 0,47 \\
\hline & & & & & 0,48 \\
\hline & & & & média & 0,51 \\
\hline & & & & desvio padráo & 0,04 \\
\hline
\end{tabular}




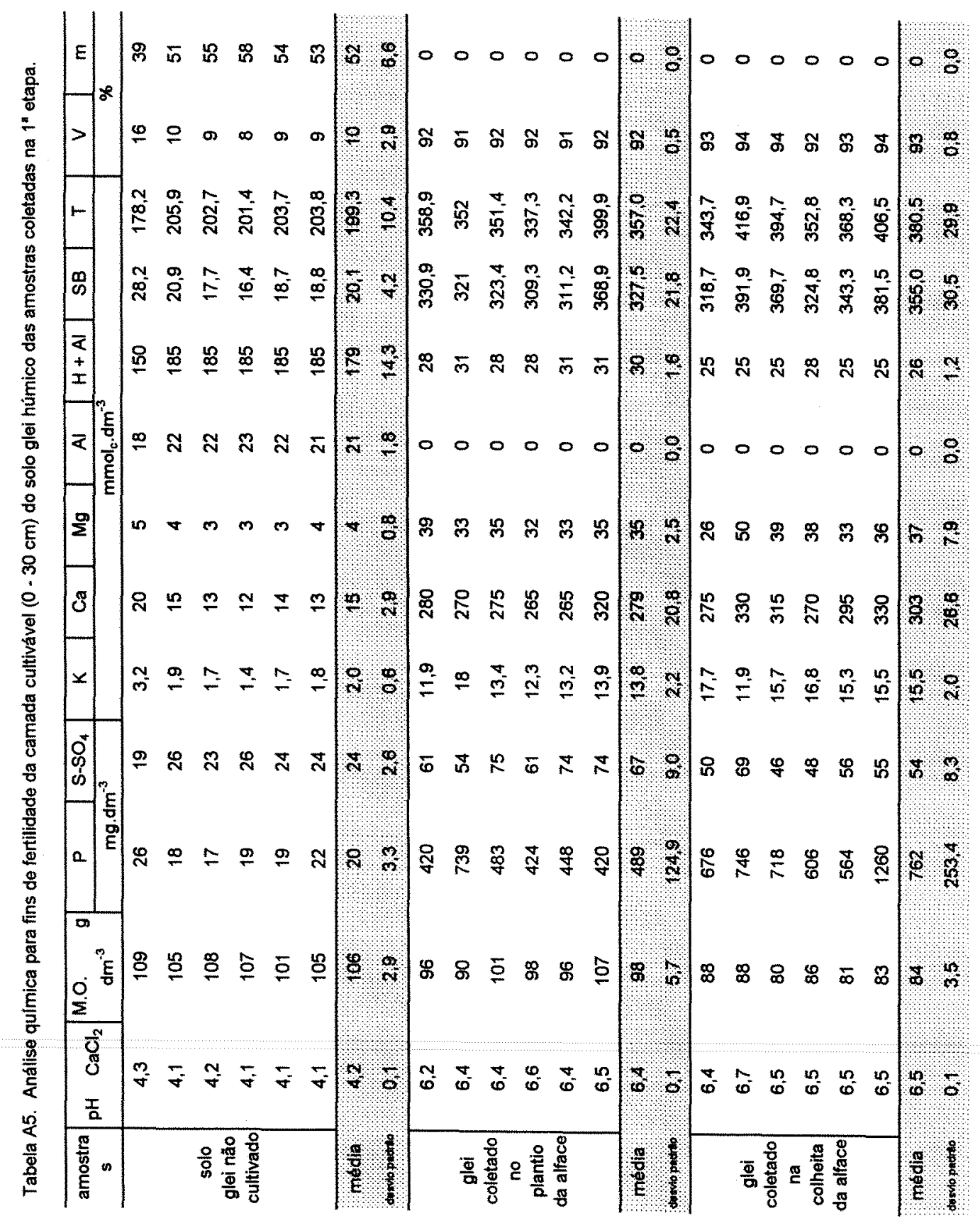




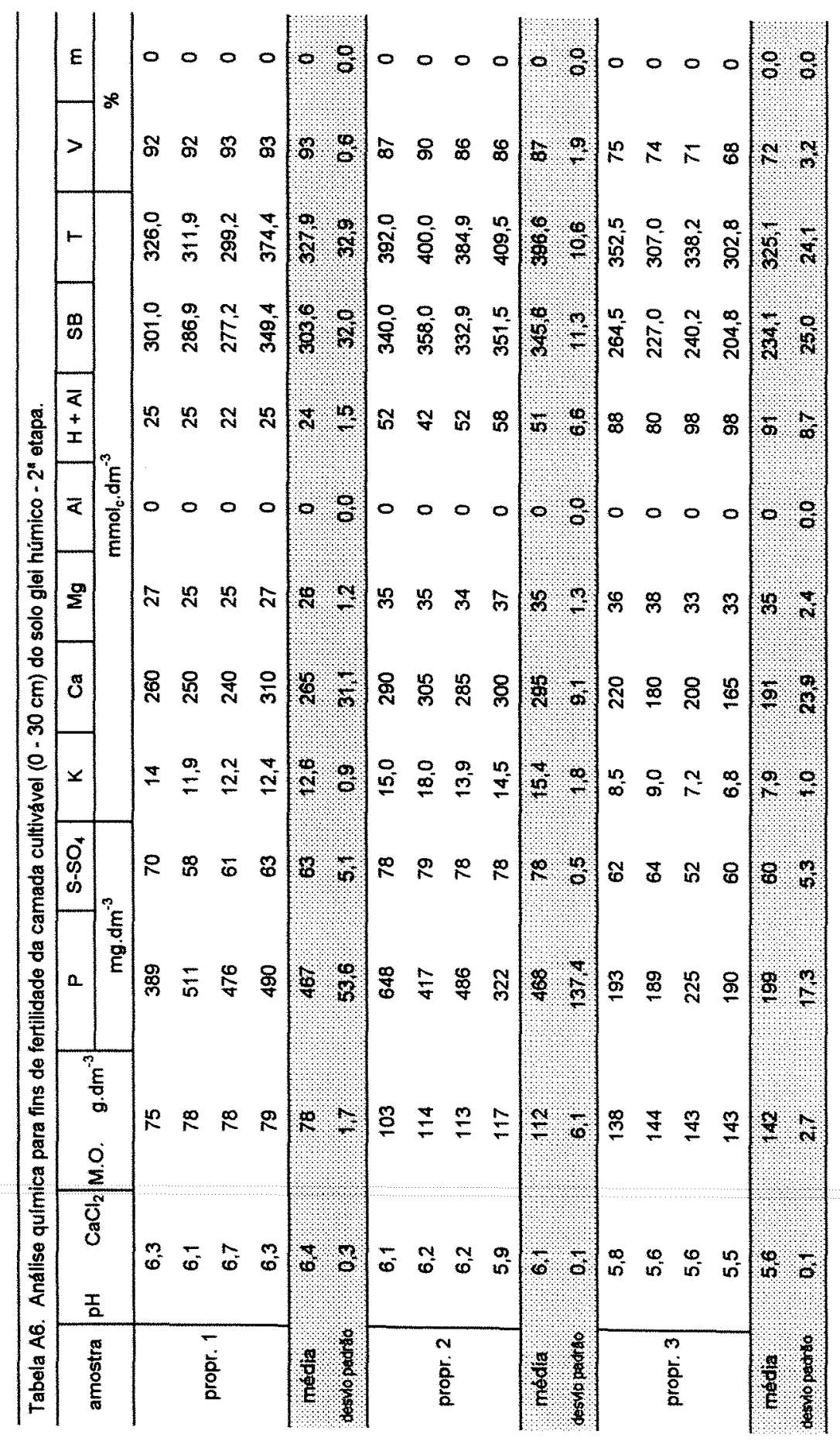




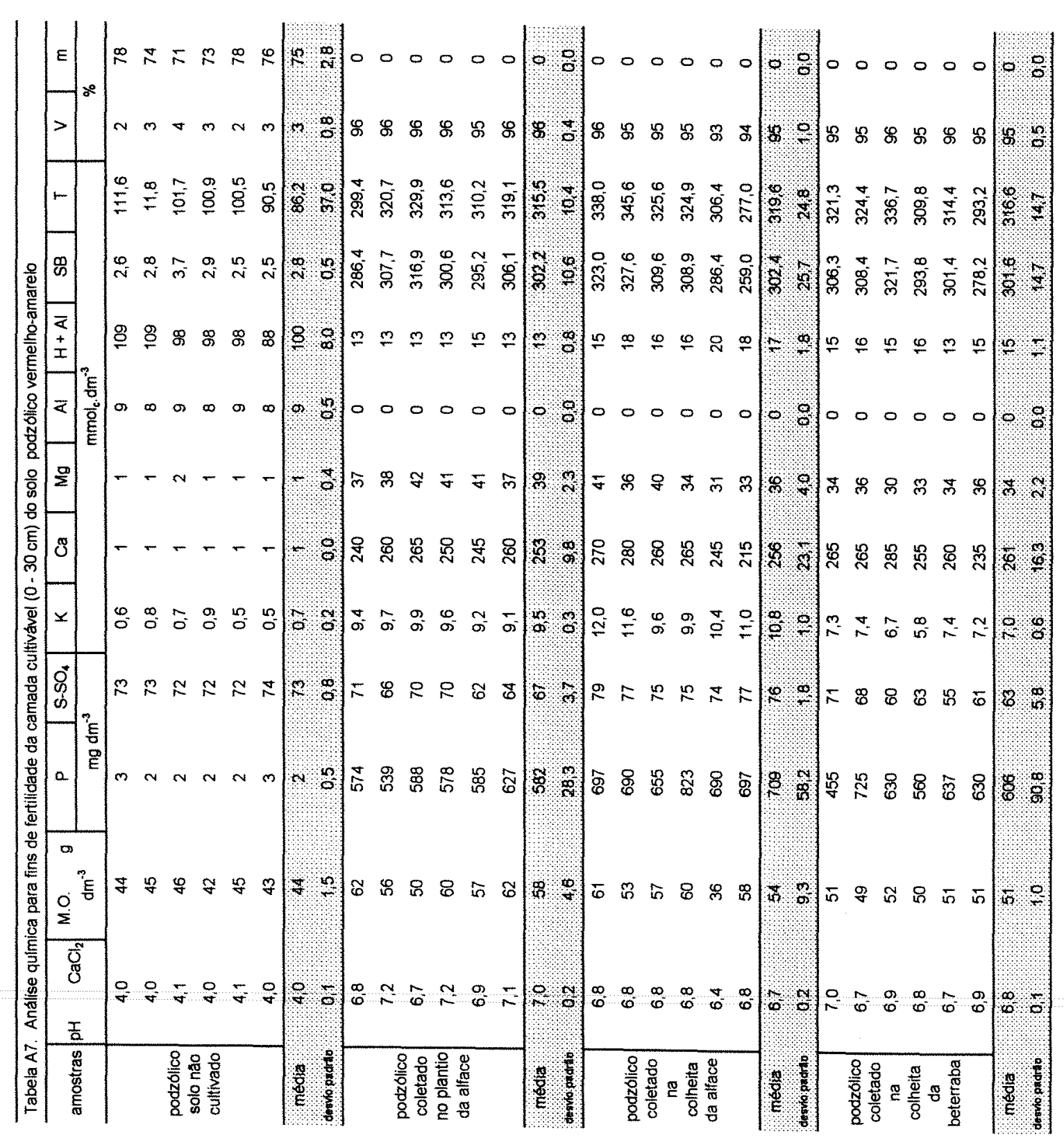


Tabela A8. Teores observados em extratos da digestão nítrica. perclórica das amostras do glei húmico através do plasma para o Mo e em espectrofotômetro de absorção atômica para os demais elementos ( $1^{\mathrm{a}}$ etapa)

\begin{tabular}{|c|c|c|c|c|c|c|c|c|c|}
\hline elementos & $\mathrm{Cd}$ & $\mathrm{Cr}$ & $\mathrm{Cu}$ & $\mathrm{Fe}$ & Mn & Mo & $\mathrm{Ni}$ & $\mathrm{Pb}$ & $\mathrm{Zn}$ \\
\hline amostras & \multicolumn{9}{|c|}{$\mathrm{mg} \mathrm{kg}^{-1}$} \\
\hline \multirow{6}{*}{$\begin{array}{l}\text { solo não } \\
\text { cultivado }\end{array}$} & 3,8 & 24 & 11 & 8800 & 42 & 14 & 13 & - & 38 \\
\hline & 3,5 & 8 & 20 & 6400 & 50 & 18 & 10 & 58 & 35 \\
\hline & 3,7 & 9 & 22 & 6640 & 51 & 16 & 10 & 60 & 36 \\
\hline & 3,5 & 10 & 20 & 6760 & 51 & 15 & 10 & 25 & 36 \\
\hline & 3,5 & 8 & 18 & 6610 & 50 & 17 & 12 & 34 & 35 \\
\hline & 3,6 & 6 & 17 & 6510 & 60 & 16 & 9 & 49 & 36 \\
\hline \multirow{2}{*}{$\begin{array}{l}\text { média } \\
\text { desvio padrao }\end{array}$} & 3.6 & 11 & 18 & 6953 & 51 & 16 & 11 & 45 & 36 \\
\hline & 0,1 & 6,0 & 3,5 & 833 & 5,2 & 1,4 & 1,4 & 14 & 1.0 \\
\hline \multirow{6}{*}{$\begin{array}{c}\text { coletada } \\
\text { no } \\
\text { plantio } \\
\text { da alface }\end{array}$} & 6,0 & 32 & 76 & 12790 & 121 & 30 & 12 & 57 & 176 \\
\hline & 4,7 & 30 & 69 & 12170 & 113 & 28 & 9 & 52 & 161 \\
\hline & 6,3 & 36 & 94 & 14150 & 120 & 33 & 12 & 66 & 182 \\
\hline & 6,4 & 37 & 87 & 13570 & 130 & 33 & 12 & 80 & 224 \\
\hline & 6,6 & 37 & 90 & 15630 & 132 & 35 & 12 & 82 & 199 \\
\hline & 6,2 & 42 & 84 & 14500 & 127 & 33 & 11 & 77 & 182 \\
\hline \multirow{2}{*}{$\begin{array}{l}\text { média } \\
\text { dosvio padréo }\end{array}$} & 6,0 & 36 & 83 & 13802 & 124 & 32 & 11 & 69 & 187 \\
\hline & 0,7 & 4,2 & 9,3 & 1240 & 7,1 & 2,4 & 1,2 & 13. & 22 \\
\hline \multirow{6}{*}{$\begin{array}{c}\text { coletada } \\
\text { na } \\
\text { colheita } \\
\text { da alface }\end{array}$} & 5,2 & 32 & 71 & 12360 & 150 & 27 & 15 & 31 & 149 \\
\hline & 4,6 & 26 & 62 & 10560 & 125 & 23 & 11 & 35 & 132 \\
\hline & 5,1 & 24 & 62 & 12560 & 139 & 24 & 13 & 92 & 138 \\
\hline & 5,2 & 33 & 68 & 11170 & 145 & 25 & 13 & 90 & 150 \\
\hline & 4,7 & 33 & 72 & 10580 & 143 & 23 & 17 & 99 & 146 \\
\hline & 4,7 & 30 & 61 & 10540 & 135 & 24 & 12 & 51 & 142 \\
\hline média & 4,9 & 30 & 66 & 11295 & 140 & 24 & 14 & 66 & 143 \\
\hline desvio padráo & 0,3 & 3,8 & 4,9 & 935 & 8,8 & 1,4 & 2,2 & 31 & 6,9 \\
\hline
\end{tabular}


Tabela A9. Teores observados em extratos da digestão nítricaperclórica das amostras do solo glei, em espectrofotômetro de absorção atômica (AAS) (2a etapa)

\begin{tabular}{|c|c|c|c|c|c|c|c|c|c|}
\hline elementos & $\mathrm{Cd}$ & $\mathrm{Cr}$ & $\mathrm{Cu}$ & $\mathrm{Fe}$ & $\mathrm{Mn}$ & Mo & $\mathrm{Ni}$ & $\mathrm{Pb}$ & $\mathrm{Zn}$ \\
\hline amostras & \multicolumn{9}{|c|}{$\mathrm{mg} \mathrm{kg}^{-1}$} \\
\hline \multirow{4}{*}{ 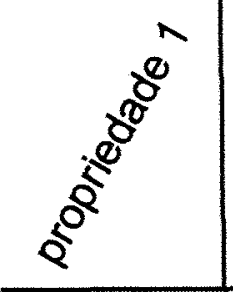 } & 2,0 & 17 & 70 & 10678 & 130 & - & 10 & 110 & 132 \\
\hline & 2,0 & 19 & 77 & 10195 & 122 & - & 11 & 130 & 139 \\
\hline & 2,0 & 17 & 80 & 10223 & 125 & - & 11 & 120 & 141 \\
\hline & 2,0 & 19 & 82 & 11273 & 233 & - & 10 & 120 & 154 \\
\hline \multirow{2}{*}{$\begin{array}{l}\text { média } \\
\text { esvio padräo }\end{array}$} & 2,0 & 18 & 77 & 10592 & 153 & - & 11 & 120 & 142 \\
\hline & 0,0 & 1,2 & 5,3 & 504,8 & 53,8 & & 0,6 & 8,2 & 9,2 \\
\hline \multirow{4}{*}{$\sum^{\delta^{2}}$} & 2,0 & 19 & 22 & 4690 & 62 & - & 8 & 70 & 78 \\
\hline & 1,0 & 19 & 23 & 4590 & 65 & - & 10 & 70 & 78 \\
\hline & 1,0 & 20 & 26 & 4660 & 77 & - & 15 & 80 & 78 \\
\hline & 2,0 & 21 & 27 & 4420 & 69 & - & 15 & 70 & 74 \\
\hline \multirow{2}{*}{$\begin{array}{l}\text { média } \\
\text { desvio padrăo }\end{array}$} & 1,5 & 20 & 25 & 4590 & 68 & - & 12 & 73 & 77 \\
\hline & 0,6 & 1 & 2 & 121 & 7 & & 4 & 5 & 2 \\
\hline \multirow{4}{*}{$\sum^{\delta^{8}}$} & 2,0 & 11 & 17 & 3760 & 40 & - & 8 & 70 & 54 \\
\hline & 2,0 & 11 & 16 & 3690 & 41 & - & 8 & 80 & 69 \\
\hline & 1,0 & 9 & 14 & 3490 & 40 & - & 7 & 70 & 50 \\
\hline & 1,0 & 8 & 12 & 3390 & 32 & - & 8 & 70 & 39 \\
\hline média & 1,5 & 10 & 15 & 3583 & 38 & - & 8 & 73 & 53 \\
\hline desvio padráo & 0,6 & 1,5 & 2,2 & 171,9 & 4,2 & & 0.5 & 5,0 & 12,4 \\
\hline
\end{tabular}




\begin{tabular}{|c|c|c|c|c|c|c|c|c|c|}
\hline elementos & $\mathrm{Cd}$ & $\mathrm{Cr}$ & $\mathrm{Cu}$ & $\mathrm{Fe}$ & $\mathrm{Mn}$ & Mo & $\mathrm{Ni}$ & $\mathrm{Pb}$ & $\mathrm{Zn}$ \\
\hline amostras & \multicolumn{9}{|c|}{$\mathrm{mg} \mathrm{kg}^{-1}$} \\
\hline \multirow{6}{*}{$\begin{array}{l}\text { solo não } \\
\text { cultivado }\end{array}$} & 23,9 & 57 & 22 & 67220 & 38 & 149 & 10 & 27 & 37 \\
\hline & 20,7 & 27 & 27 & 60750 & 38 & 138 & 11 & 48 & 25 \\
\hline & 25,2 & 29 & 32 & 61080 & 39 & 143 & 11 & 15 & 24 \\
\hline & 20,7 & 27 & 29 & 60860 & 41 & 152 & 9 & 0 & 24 \\
\hline & 22,6 & 29 & 30 & 62000 & 40 & 140 & 6 & 32 & 26 \\
\hline & 23,1 & 27 & 32 & 61170 & 40 & 148 & 10 & 0 & 25 \\
\hline média & 22,7 & 33 & 29 & 62180 & 39 & 145 & 10 & 31 & 27 \\
\hline desvio pedráo & 18 & 12 & 38 & 2508 & 1,2 & 55 & 19 & 19 & 5,0 \\
\hline \multirow{6}{*}{$\begin{array}{c}\text { coletada } \\
\text { no plantio } \\
\text { da alface }\end{array}$} & 24,0 & 47 & 77 & 68970 & 117 & 142 & 18 & 65 & 181 \\
\hline & 20,8 & 67 & 77 & 69000 & 121 & 132 & 12 & 63 & 175 \\
\hline & 20,2 & 63 & 74 & 59290 & 101 & 126 & 11 & 75 & 165 \\
\hline & 20,5 & 61 & 71 & 58870 & 100 & 126 & 13 & 32 & 162 \\
\hline & 21,2 & 63 & 69 & 56580 & 101 & 130 & 14 & 30 & 161 \\
\hline & 20,8 & 63 & 71 & 69210 & 112 & 129 & 15 & 39 & 214 \\
\hline media & 21,3 & 61 & 73 & 63653 & 100 & 131 & 14 & 51 & 176 \\
\hline dosvio podtrao & 14 & 70 & 3,4 & 5995 & 92 & 6,0 & 25 & 19 & 20 \\
\hline \multirow{6}{*}{$\begin{array}{c}\text { coletada } \\
\text { na colheita } \\
\text { da alface }\end{array}$} & 20,8 & 64 & 80 & 77050 & 107 & 126 & 15 & 48 & 183 \\
\hline & 19,7 & 61 & 80 & 55110 & 101 & 125 & 13 & 63 & 173 \\
\hline & 21,4 & 60 & 79 & 58630 & 105 & 132 & 14 & 65 & 176 \\
\hline & 19,7 & 61 & 81 & 59360 & 100 & 119 & 14 & 73 & 159 \\
\hline & 21,5 & 67 & 80 & 57380 & 106 & 132 & 15 & 47 & 164 \\
\hline & 19,9 & 63 & 77 & 54970 & 100 & 124 & 17 & 48 & 172 \\
\hline media & 206 & 63 & 80 & 60417 & 103 & 126 & 15 & 57 & 171 \\
\hline desvio peträ́o & 08 & 2,6 & $11^{4}$ & 8343 & 32 & 49 & 144 & 11 & 8.6 \\
\hline \multirow{6}{*}{$\begin{array}{c}\text { coletada } \\
\text { na colheita } \\
\text { da } \\
\text { beterraba }\end{array}$} & 18,4 & 58 & 63 & 51840 & 91 & 115 & 10 & 0 & 142 \\
\hline & 18,0 & 71 & 61 & 48930 & 91 & 109 & 24 & 0 & 141 \\
\hline & 17,0 & 57 & 60 & 48400 & 89 & 106 & 12 & 0 & 145 \\
\hline & 18,1 & 55 & 59 & 51940 & 87 & 111 & 11 & 0 & 136 \\
\hline & 16,1 & 50 & 59 & 44650 & 77 & 100 & 10 & 0 & 132 \\
\hline & 17,6 & 55 & 60 & 52950 & 86 & 113 & 12 & 0 & 136 \\
\hline média & 175 & 58 & 60 & 49785 & 87 & 109 & 13 & 0 & 139 \\
\hline desvio podráo & 0,9 & 71 & 1,5 & 3095 & 5,2 & 52 & 54 & 0 & 4.8 \\
\hline
\end{tabular}


Tabela A11. Análise Química de micronutrientes para fins de fertilidade, da camada cultivável $(0-30 \mathrm{~cm})$ do solo glei húmico $\left(1^{\mathrm{a}}\right.$ etapa).

\begin{tabular}{|c|c|c|c|c|c|}
\hline \multirow{2}{*}{ amostras } & $\mathrm{B}$ & $\mathrm{Cu}$ & $\mathrm{Fe}$ & $\mathrm{Mn}$ & $\mathrm{Zn}$ \\
\hline & \multicolumn{5}{|c|}{$\mathrm{mg} \mathrm{dm}^{-3}$} \\
\hline \multirow{6}{*}{$\begin{array}{l}\text { glei não } \\
\text { cultivado }\end{array}$} & 7,54 & 0,6 & 106,0 & 2,8 & 1,7 \\
\hline & 5,10 & 0,2 & 99,6 & 3,2 & 0,8 \\
\hline & 5,55 & 0,2 & 97,0 & 3,0 & 0,9 \\
\hline & 5,58 & 0,2 & 100,0 & 2,8 & 0,8 \\
\hline & 5,45 & 0,3 & 100,8 & 3,6 & 1,0 \\
\hline & 5,15 & 0,3 & 102,2 & 3,0 & 0,8 \\
\hline \multirow{2}{*}{$\begin{array}{c}\text { media } \\
\text { desvio padräo }\end{array}$} & 5,73 & 0,3 & 100,9 & 3,1 & 1,0 \\
\hline & 0,9 & 0,2 & 3,0 & 0,3 & 0,4 \\
\hline \multirow{6}{*}{$\begin{array}{c}\text { glei } \\
\text { coletado no } \\
\text { plantio } \\
\text { da alface }\end{array}$} & 4,64 & 1,9 & 150,0 & 12,2 & 36,2 \\
\hline & 5,77 & 23,6 & 137,0 & 17,8 & 49,0 \\
\hline & 6,72 & 21,0 & 171,0 & 16,0 & 46,6 \\
\hline & 4,84 & 19,2 & 150,0 & 13,8 & 38,6 \\
\hline & 5,22 & 18,0 & 147,0 & 13,6 & 39,0 \\
\hline & 5,27 & 20,0 & 163,0 & 14,8 & 42,0 \\
\hline \multirow{3}{*}{$\begin{array}{c}\text { media } \\
\text { desvio padräo }\end{array}$} & 5.41 & 173 & 153,0 & 14.7 & 41,9 \\
\hline & 0,8 & 7.8 & 12,1 & 2,0 & 5,0 \\
\hline & 6,02 & 23,4 & 141,0 & 18,0 & 48,4 \\
\hline \multirow{5}{*}{$\begin{array}{c}\text { glei } \\
\text { coletado na } \\
\text { colheita } \\
\text { da alface }\end{array}$} & 4,95 & 20,6 & 173,0 & 13,4 & 41,0 \\
\hline & 6,66 & 24,8 & 143,0 & 16,0 & 44,6 \\
\hline & 6,40 & 24,4 & 145,0 & 15,8 & 44,4 \\
\hline & 9,70 & 25,4 & 132,0 & 16,6 & 42,0 \\
\hline & 10,02 & 26,4 & 148,0 & 18,0 & 46,0 \\
\hline \multirow{2}{*}{$\begin{array}{l}\text { média } \\
\text { desvio padräo }\end{array}$} & 7,29 & 24,2 & 147,0 & 16,3 & 44,4 \\
\hline & 2,08 & 2,01 & 13,84 & 1,71 & 2,68 \\
\hline
\end{tabular}


Tabela A12. Análise Química de micronutrientes para fins de fertilidade, da camada cultivável $(0-30 \mathrm{~cm})$ do solo glei húmico (2a $2^{\mathrm{a}}$ etapa).

\begin{tabular}{|c|c|c|c|c|c|}
\hline \multirow{2}{*}{ amostras } & $B$ & $\mathrm{Cu}$ & $\mathrm{Fe}$ & $\mathrm{Mn}$ & $\mathrm{Zn}$ \\
\hline & \multicolumn{5}{|c|}{$\mathrm{mg} \mathrm{dm}^{3}$} \\
\hline \multirow{4}{*}{$\begin{array}{c}\text { glei } \\
\text { propr. } 1\end{array}$} & 1,49 & 16,8 & 97,4 & 7,6 & 30,0 \\
\hline & 1,22 & 19,2 & 101,4 & 6,8 & 34,2 \\
\hline & 1,44 & 21,0 & 114,0 & 7,2 & 32,8 \\
\hline & 1,55 & 20,6 & 113,0 & 8,0 & 34,6 \\
\hline \multirow{2}{*}{$\begin{array}{l}\text { média } \\
\text { desvio padrao }\end{array}$} & 1,43 & 19.4 & 106,5 & 7,4 & 32,9 \\
\hline & 0,14 & 190 & 8,31 & 0,52 & 2,08 \\
\hline \multirow{4}{*}{$\begin{array}{c}\text { glei } \\
\text { propr. } 2 \\
\left(2^{\mathrm{a}} \text { etapa }\right)\end{array}$} & 7,42 & 1,9 & 29,6 & 4,4 & 14,1 \\
\hline & 7,48 & 1,4 & 27,4 & 3,6 & 12,4 \\
\hline & 6,40 & 1,4 & 28,4 & 4,0 & 11,8 \\
\hline & 6,34 & 1,3 & 30,0 & 4,2 & 11,0 \\
\hline \multirow{2}{*}{$\begin{array}{l}\text { média } \\
\text { desvio padra }\end{array}$} & 6,91 & 15 & 28.9 & 41 & 12,3 \\
\hline & 0,62 & 0,27 & 1,18 & 0,34 & 131 \\
\hline \multirow{4}{*}{$\begin{array}{c}\text { glei } \\
\text { propr. } 3\end{array}$} & 1,45 & 0,9 & 25,2 & 2,2 & 7,7 \\
\hline & 1,31 & 0,8 & 23,6 & 2,4 & 8,4 \\
\hline & 0,93 & 0,8 & 27,2 & 2,0 & 7,3 \\
\hline & 1,13 & 0,7 & 25,0 & 1,8 & 7,1 \\
\hline \multirow{2}{*}{$\begin{array}{c}\text { media } \\
\text { desvio padrao }\end{array}$} & 121 & 0.8 & 25,3 & 21 & 7,6 \\
\hline & 0,23 & 0,08 & 1,48 & 0,26 & 0,57 \\
\hline
\end{tabular}


Tabela A13. Análise Química de micronutrientes para fins de fertilidade, da camada cultivável $(0-30 \mathrm{~cm})$ do solo podzólico vermelho-amarelo.

\begin{tabular}{|c|c|c|c|c|c|}
\hline \multirow{2}{*}{ amostras } & $B$ & $\mathrm{Cu}$ & $\mathrm{Fe}$ & $\mathrm{Mn}$ & $\mathrm{Zn}$ \\
\hline & \multicolumn{5}{|c|}{$\mathrm{mg} \mathrm{dm}^{-3}$} \\
\hline \multirow{6}{*}{$\begin{array}{l}\text { podzólico } \\
\text { não } \\
\text { cultivado }\end{array}$} & 0,76 & 1,1 & 57,6 & 1,8 & 1,3 \\
\hline & 0,87 & 1,2 & 56,2 & 1,9 & 1,2 \\
\hline & 0,83 & 1,2 & 57,4 & 1,8 & 1,3 \\
\hline & 0,87 & 1,1 & 59 & 1,9 & 1,2 \\
\hline & 0,86 & 1,2 & 59,2 & 1,9 & 1,3 \\
\hline & 0,86 & 1,2 & 57,2 & 1,7 & 1,2 \\
\hline \multirow{2}{*}{$\begin{array}{l}\text { media } \\
\text { desvio padra }\end{array}$} & 0,84 & 1,2 & $57 \%$ & 1.8 & 1,3 \\
\hline & 0,04 & 0,05 & 1,14 & 0,08 & 0,05 \\
\hline \multirow{6}{*}{$\begin{array}{c}\text { podzólico } \\
\text { coletado no } \\
\text { plantio da } \\
\text { alface }\end{array}$} & 7,16 & 19,3 & 68,6 & 29 & 47,8 \\
\hline & 7,86 & 18,9 & 66 & 29,2 & 46,4 \\
\hline & 5,9 & 18,8 & 66,6 & 29,6 & 45 \\
\hline & 7,1 & 17,9 & 62,4 & 30 & 43,6 \\
\hline & 7,61 & 17,9 & 67 & 31,2 & 45,8 \\
\hline & 7,23 & 18,4 & 61 & 29,6 & 42,6 \\
\hline \multirow{2}{*}{$\begin{array}{l}\text { média } \\
\text { desvopadrao }\end{array}$} & 7,14 & 18,5 & 65,3 & 29.8 & $45 \%$ \\
\hline & 0,68 & 0,57 & 2,93 & 0,78 & 1,89 \\
\hline \multirow{6}{*}{$\begin{array}{c}\text { podzólico } \\
\text { coletado na } \\
\text { colheita da } \\
\text { alface }\end{array}$} & 7,54 & 17,6 & 74,2 & 33,8 & 46,8 \\
\hline & 8,37 & 17,8 & 73,4 & 33,8 & 47,4 \\
\hline & 8,12 & 18,2 & 82,6 & 36,8 & 47,2 \\
\hline & 8,18 & 18 & 83,6 & 36,2 & 47,6 \\
\hline & 8,43 & 18,4 & 90,4 & 36,2 & 49,8 \\
\hline & 8,81 & 17,4 & 79,6 & 33 & 47,2 \\
\hline \multirow{2}{*}{$\begin{array}{l}\text { media } \\
\text { desvo padrao }\end{array}$} & 8,24 & 179 & 80.6 & 35,0 & $47 \%$ \\
\hline & 0.42 & 0,37 & 6.37 & 1.61 & 1,08 \\
\hline \multirow{6}{*}{$\begin{array}{c}\text { podzólico } \\
\text { coletado na } \\
\text { colheita da } \\
\text { beterraba }\end{array}$} & 11,41 & 16,2 & 70,4 & 28,4 & 44,0 \\
\hline & 8,75 & 14,4 & 52,8 & 23,0 & 37,6 \\
\hline & 8,56 & 13,6 & 53,6 & 23,0 & 33,4 \\
\hline & 7,67 & 15,0 & 60,8 & 25,8 & 37,0 \\
\hline & 7,35 & 16,2 & 66,0 & 26,0 & 38,8 \\
\hline & 7,48 & 17,0 & 66,8 & 25,8 & 40,0 \\
\hline \multirow{2}{*}{$\begin{array}{c}\text { media } \\
\text { desviopadrao }\end{array}$} & 8.54 & 15.4 & 61.7 & 25,3 & 38,5 \\
\hline & 1,52 & 1,28 & 7,29 & 2,06 & 3,51 \\
\hline
\end{tabular}


Tabela A14. Teores de elementos químicos nas amostras do solo glei húmico após extração com $\mathrm{Mg} \mathrm{Cl}$ em fracionamento seqüencial $\left(\mathrm{MgCl}_{2}\right.$, acetato de sódio, hidroxilamina, nítrico/ $\mathrm{H}_{2} \mathrm{O}_{2}$, nítrico-perclórico).

\begin{tabular}{c|c|c|c|c|c|c|c|c}
\hline MgCl & $\mathrm{Cd}$ & $\mathrm{Cr}$ & $\mathrm{Cu}$ & $\mathrm{Fe}$ & $\mathrm{Mn}$ & $\mathrm{Ni}$ & $\mathrm{Pb}$ & $\mathrm{Zn}$ \\
\cline { 2 - 9 } amostra & \multicolumn{7}{c}{$\mathrm{mg} \mathrm{kg}^{-1}$} \\
\hline & 0,00 & 0,00 & 0,00 & 0,0 & 125 & 0,00 & 0,00 & 1,75 \\
não & 0,00 & 0,25 & 0,00 & 5,3 & 169 & 0,00 & 0,00 & 0,75 \\
cultivado & 0,00 & 0,00 & 0,00 & 9,0 & 195 & 0,00 & 0,00 & 1,75 \\
& 0,00 & 0,00 & 0,00 & 0,00 & 132 & 0,00 & 0,00 & 1,00 \\
& 0,00 & 0,00 & 0,00 & 3,25 & 202 & 0,25 & 0,00 & 1,25 \\
média & 0,00 & 0,05 & 0,00 & 3,50 & 164 & 0,05 & 0,00 & 1,30 \\
desvio padrão & 0,00 & 0,11 & 0,00 & 3,80 & 35,3 & 0,11 & 0,00 & 0,45 \\
\hline & 0,20 & 0,00 & 0,00 & 0,00 & 159 & 0,00 & 0,00 & 0,00 \\
coletado & 0,20 & 0,25 & 0,25 & 0,00 & 175 & 0,00 & 0,00 & 0,00 \\
no plantio & 0,20 & 0,50 & 0,25 & 0,00 & 172 & 0,00 & 0,00 & 0,00 \\
da alface & 0,20 & 0,00 & 0,25 & 0,00 & 175 & 0,00 & 0,00 & 0,00 \\
& 0,20 & 0,50 & 0,25 & 0,00 & 172 & 0,00 & 0,00 & 0,00 \\
& 0,00 & 0,50 & 0,50 & 0,00 & 171 & 0,00 & 0,00 & 0,00 \\
média & 0,17 & 0,29 & 0,25 & 0,00 & 171 & 0,00 & 0,00 & 0,00 \\
desvio padrão & 0,08 & 0,25 & 0,16 & 0,00 & 5,98 & 0,00 & 0,00 & 0,00 \\
\hline & 0,00 & 0,25 & 0,00 & 0,00 & 166 & 0,00 & 0,00 & 0,00 \\
coletado & 0,00 & 0,25 & 0,00 & 0,00 & 141 & 0,00 & 0,00 & 0,00 \\
na colheita & 0,00 & 0,00 & 0,25 & 0,00 & 167 & 0,00 & 0,00 & 0,00 \\
da alface & 0,20 & 0,25 & 0,50 & 0,00 & 163 & 0,00 & 0,00 & 0,00 \\
& 0,20 & 0,00 & 0,25 & 0,00 & 174 & 0,00 & 0,00 & 0,00 \\
& 0,20 & 0,50 & 0,00 & 0,00 & 158 & 0,00 & 0,00 & 0,00 \\
média & 0,10 & 0,21 & 0,17 & 0,00 & 161 & 0,00 & 0,00 & 0,00 \\
desvio padrão & 0,11 & 0,19 & 0,20 & 0,00 & 11,37 & 0,00 & 0,00 & 0,00 \\
\hline & & & & & & & &
\end{tabular}


Tabela A15.Teores de elementos químicos nas amostras do solo glei húmico após extração com acetato de sódio em fracionamento seqüencial $\left(\mathrm{MgCl}_{2}\right.$, acetato de sódio, hidroxilamina, nítrico $/ \mathrm{H}_{2} \mathrm{O}_{2}$, nítrico-perclórico).

\begin{tabular}{|c|c|c|c|c|c|c|c|c|}
\hline \multirow{2}{*}{$\begin{array}{l}\text { acetato Na } \\
\text { amostra }\end{array}$} & $\mathrm{Cd}$ & $\mathrm{Cr}$ & $\mathrm{Cu}$ & $\mathrm{Fe}$ & $\mathrm{Mn}$ & $\mathrm{Ni}$ & $\mathrm{Pb}$ & $\mathrm{Zn}$ \\
\hline & \multicolumn{8}{|c|}{$\mathrm{mg} \mathrm{kg}^{-1}$} \\
\hline \multirow{5}{*}{$\begin{array}{c}\text { não } \\
\text { cultivado }\end{array}$} & 0,00 & 0,25 & 0,00 & 42 & 8,75 & 0,00 & 0,00 & 0,00 \\
\hline & 0,00 & 0,25 & 0,00 & 46 & 8,50 & 0,00 & 0,00 & 0,00 \\
\hline & 0,00 & 0,25 & 0,00 & 45 & 9,50 & 0,00 & 0,00 & 0,00 \\
\hline & 0,00 & 0,25 & 0,00 & 42 & 7,50 & 0,00 & 0,00 & 0,00 \\
\hline & 0,00 & 0,25 & 0,00 & 45 & 10,25 & 0,00 & 0,00 & 0,00 \\
\hline média & 0,00 & 0,25 & 0,00 & 44,10 & 8,90 & 0,00 & 0,00 & 0,00 \\
\hline \multirow{2}{*}{ desvio padrăo } & 0,00 & 0,00 & 0,00 & 1,84 & 1,04 & 0,00 & 0,00 & 0,00 \\
\hline & 0,00 & 0,00 & 3,00 & 0,00 & 64,0 & 0,00 & 0,00 & 36,0 \\
\hline \multirow{5}{*}{$\begin{array}{l}\text { coletado } \\
\text { no plantio } \\
\text { da alface }\end{array}$} & 0,00 & 0,00 & 3,25 & 0,00 & 66,0 & 0,00 & 0,00 & 60,0 \\
\hline & 0,00 & 0,00 & 3,25 & 0,00 & 58,0 & 0,00 & 0,00 & 37,0 \\
\hline & 0,00 & 0,00 & 3,00 & 0,00 & 56,5 & 0,00 & 0,00 & 35,5 \\
\hline & 0,00 & 0,00 & 3,25 & 0,00 & 58,0 & 0,00 & 0,00 & 35,8 \\
\hline & 0,00 & 0,00 & 3,50 & 0,00 & 61,0 & 0,00 & 0,00 & 38,8 \\
\hline média & 0,00 & 0,00 & 3,21 & 0,00 & 60,6 & 0,00 & 0,00 & 40,5 \\
\hline \multirow[t]{2}{*}{ desvio padrāo } & 0,00 & 0,00 & 0,19 & 0,00 & 3,77 & 0,00 & 0,00 & 9,63 \\
\hline & 0,00 & 0,00 & 2,50 & 0,00 & 69,5 & 0,00 & 0,00 & 23,5 \\
\hline coletado & 0,00 & 0,00 & 2,50 & 1,00 & 72,5 & 0,00 & 0,00 & 25,5 \\
\hline na & 0,00 & 0,00 & 2,50 & 0,75 & 69,3 & 0,00 & 0,00 & 24,5 \\
\hline colheita & 0,00 & 0,00 & 3,75 & 0,75 & 68,8 & 0,00 & 0,00 & 25,3 \\
\hline \multirow[t]{2}{*}{ da alface } & 0,00 & 0,00 & 2,00 & 0,25 & 62,5 & 0,00 & 0,00 & 27,3 \\
\hline & 0,00 & 0,00 & 2,25 & 1,75 & 62,5 & 0,00 & 0,00 & 26,8 \\
\hline média & 0,00 & 0,00 & 2,58 & 0,75 & 67,5 & 0,00 & 0,00 & 25,5 \\
\hline desvio padräo & 0,00 & 0,00 & 0,61 & 0,61 & 4,09 & 0,00 & 0,00 & 1,39 \\
\hline
\end{tabular}


Tabela A16. Teor de elementos químicos nas amostras do solo glei húmico após extração com hidroxilamina em fracionamento seqüencial $\left(\mathrm{MgCl}_{2}\right.$, acetato de sódio, hidroxilamina, nítrico/ $\mathrm{H}_{2} \mathrm{O}_{2}$, nítrico-perclórico).

\begin{tabular}{|c|c|c|c|c|c|c|c|c|}
\hline \multirow{2}{*}{$\begin{array}{l}\text { hidroxilamina } \\
\text { amostra }\end{array}$} & $\mathrm{Cd}$ & $\mathrm{Cr}$ & $\mathrm{Cu}$ & $\mathrm{Fe}$ & $\mathrm{Mn}$ & $\mathrm{Ni}$ & $\mathrm{Pb}$ & $\mathrm{Zn}$ \\
\hline & \multicolumn{8}{|c|}{$\mathrm{mg} \mathrm{kg}^{-1}$} \\
\hline \multirow{5}{*}{$\begin{array}{c}\text { não } \\
\text { cultivado }\end{array}$} & 0,20 & 2,00 & 0,00 & 1325 & 13,8 & 0,75 & 4,75 & 4,50 \\
\hline & 0,00 & 2,25 & 0,00 & 1170 & 13,0 & 2,50 & 4,50 & 3,50 \\
\hline & 0,20 & 2,75 & 0,00 & 1213 & 12,5 & 2,50 & 3,50 & 4,00 \\
\hline & 0,20 & 2,25 & 0,00 & 1175 & 12,0 & 2,50 & 4,25 & 4,75 \\
\hline & 0,20 & 2,50 & 0,00 & 1233 & 12,3 & 2,50 & 3,50 & 4,25 \\
\hline \multirow{3}{*}{$\begin{array}{l}\text { média } \\
\text { esvio padrão }\end{array}$} & 0,16 & 2,35 & 0,00 & 1223 & 12,7 & 2,15 & 4,10 & 4,20 \\
\hline & 0,00 & 0,22 & 1,14 & 167,80 & 11,57 & 0,10 & 1,19 & 11,71 \\
\hline & 0,20 & 4,50 & 7,25 & 2368 & 139 & 2,50 & 14,3 & 104 \\
\hline \multirow{5}{*}{$\begin{array}{l}\text { coletado } \\
\text { no plantio } \\
\text { da alface }\end{array}$} & 0,20 & 4,50 & 7,75 & 2415 & 135 & 2,50 & 12,8 & 125 \\
\hline & 0,20 & 4,75 & 8,00 & 2640 & 129 & 2,50 & 16,0 & 113 \\
\hline & 0,20 & 4,25 & 8,50 & 2670 & 141 & 2,75 & 15,0 & 102 \\
\hline & 0,20 & 4,25 & 8,00 & 2288 & 110 & 2,50 & 14,3 & 90 \\
\hline & 0,20 & 4,75 & 10,50 & 2650 & 122 & 2,50 & 15,8 & 105 \\
\hline média & 0,20 & 4,50 & 8,33 & 2505 & 129 & 2,54 & 14,7 & 106 \\
\hline \multirow[t]{2}{*}{ desvio padräo } & 0,00 & 0,22 & 1,14 & 167,80 & 11,57 & 0,10 & 1,19 & 11,71 \\
\hline & 0,45 & 4,00 & 6,25 & 2490 & 183 & 2,50 & 13,8 & 91,8 \\
\hline coletado & 0,20 & 4,75 & 6,00 & 2620 & 196 & 2,50 & 18,5 & 101,0 \\
\hline na & 0,20 & 4,00 & 5,50 & 2335 & 192 & 2,50 & 18,0 & 97,0 \\
\hline colheita & 0,20 & 4,00 & 9,00 & 2450 & 183 & 2,50 & 18,0 & 92,3 \\
\hline \multirow[t]{2}{*}{ da alface } & 0,20 & 4,00 & 4,75 & 2225 & 196 & 2,50 & 16,8 & 97,5 \\
\hline & 0,20 & 4,00 & 4,50 & 1903 & 168 & 2,50 & 14,8 & 83,0 \\
\hline média & 0,24 & 4,13 & 6,00 & 2337 & 186 & 2,50 & 16,6 & 93,8 \\
\hline desvio padräo & 0,10 & 0,31 & 1,62 & 252,03 & 10,82 & 0,00 & 1,95 & 6,31 \\
\hline
\end{tabular}


Tabela A17. Teores de elementos químicos nas amostras do solo glei húmico após extração com ácido nítrico/H2O2 em fracionamento seqüencial $\left(\mathrm{MgCl}_{2}\right.$, acetato de sódio, hidroxilamina, nítrico/ $\mathrm{H}_{2} \mathrm{O}_{2}$, nitrico-perclórico)

\begin{tabular}{|c|c|c|c|c|c|c|c|c|}
\hline \multirow{2}{*}{$\begin{array}{l}\text { nitrico } / \mathrm{H}_{2} \mathrm{O}_{2} \\
\text { amostra }\end{array}$} & Cd & $\mathrm{Cr}$ & $\mathrm{Cu}$ & $\mathrm{Fe}$ & $\mathrm{Mn}$ & $\mathrm{Ni}$ & $\overline{\mathrm{Pb}}$ & $\mathrm{Zn}$ \\
\hline & \multicolumn{8}{|c|}{$\mathrm{mg} \mathrm{kg}^{-1}$} \\
\hline \multirow{5}{*}{$\begin{array}{c}\text { não } \\
\text { cultivado }\end{array}$} & 0,00 & 3,50 & 3,00 & 213 & 4,25 & 3,75 & 3,75 & 0,25 \\
\hline & 0,00 & 3,75 & 1,50 & 188 & 2,25 & 2,00 & 3,00 & 1,00 \\
\hline & 0,00 & 4,00 & 2,00 & 168 & 1,75 & 2,50 & 3,25 & 0,00 \\
\hline & 0,00 & 3,75 & 2,00 & 160 & 2,00 & 1,50 & 2,50 & 0,25 \\
\hline & 0,00 & 4,00 & 1,75 & 155 & 1,50 & 1,00 & 1,75 & 1,00 \\
\hline média & 0,0 & 3,80 & 2,05 & 176,7 & 2,35 & 2,15 & 2,85 & 0,50 \\
\hline \multirow[t]{2}{*}{ desvio padrăo } & 0,0 & 0,2 & 0,6 & 24,0 & 1,1 & 1,1 & 0,8 & 0,5 \\
\hline & 0,00 & 7,75 & 62,8 & 195 & 9,75 & 0,50 & 5,75 & 22,3 \\
\hline coletado & 0,00 & 6,50 & 57,8 & 182 & 5,25 & 2,00 & 5,25 & 20,0 \\
\hline & 0,00 & 6,50 & 70,0 & 187 & 4,75 & 0,75 & 6,50 & 20,8 \\
\hline plantio & 0,00 & 6,00 & 60,3 & 148 & 4,25 & 0,75 & 5,75 & 14,5 \\
\hline \multirow[t]{2}{*}{ da alface } & 0,00 & 7,00 & 61,5 & 157 & 5,25 & 1,25 & 5,50 & 17,3 \\
\hline & 0,00 & 6,75 & 63,3 & 157 & 4,75 & 0,50 & 5,75 & 17,0 \\
\hline média & 0,00 & 6,75 & 62,6 & 170,8 & 5,67 & 0,96 & 5,75 & 18,6 \\
\hline \multirow[t]{2}{*}{ desvio padräo } & 0,00 & 0,59 & 4,13 & 19,62 & 2,04 & 0,58 & 0,42 & 2,87 \\
\hline & 0,00 & 5,75 & 53,8 & 171 & 6,75 & 4,25 & 4,25 & 14,0 \\
\hline coletado & 0,00 & 5,75 & 54,8 & 186 & 5,75 & 6,25 & 6,25 & 14,0 \\
\hline na & 0,00 & 5,50 & 56,0 & 211 & 8,50 & 2,25 & 7,50 & 20,8 \\
\hline colheita & 0,00 & 6,00 & 143 & 193 & 7,25 & 2,75 & 6,25 & 18,5 \\
\hline \multirow[t]{2}{*}{ da alface } & 0,00 & 5,75 & 54,5 & 219 & 7,25 & 1,00 & 6,50 & 18,3 \\
\hline & 0,00 & 6,00 & 64,0 & 273 & 10,0 & 3,50 & 6,50 & 25,8 \\
\hline média & 0,00 & 5,79 & 71,0 & 208,7 & 7,58 & 3,33 & 6,21 & 18,5 \\
\hline desvio padräo & 0,00 & 0,19 & 35,58 & 35,64 & 1,48 & 1,81 & 1,07 & 4,43 \\
\hline
\end{tabular}


Tabela A18. Teores de elementos químicos nas amostras do solo glei húmico após extração com ácido nítrico-perclórico em fracionamento seqüencial $\left(\mathrm{MgCl}_{2}\right.$, acetato de sódio, hidroxilamina, nítrico/ $\mathrm{H}_{2} \mathrm{O}_{2}$, nítrico-perclórico).

\begin{tabular}{c|c|c|c|c|c|c|c|c}
\hline nitr-percl & $\mathrm{Cd}$ & $\mathrm{Cr}$ & $\mathrm{Cu}$ & $\mathrm{Fe}$ & $\mathrm{Mn}$ & $\mathrm{Ni}$ & $\mathrm{Pb}$ & $\mathrm{Zn}$ \\
\cline { 2 - 8 } amostra & \multicolumn{7}{|c}{$\mathrm{mg} \mathrm{kg}^{-1}$} \\
\hline & 0,70 & 11,5 & 5,5 & 4685 & 16,3 & 1,25 & 18,8 & 21,5 \\
não & 1,20 & 12,5 & 10,0 & 4680 & 17,0 & 10,0 & 20,8 & 20,8 \\
cultivado & 1,20 & 8,75 & 8,00 & 4173 & 15,3 & 8,25 & 19,0 & 21,3 \\
& & & & & & & & \\
& 1,20 & 10,3 & 5,3 & 3990 & 15,0 & 17,0 & 17,0 & 18,8 \\
média & 1,08 & 10,8 & 7,19 & 4382 & 15,9 & 9,13 & 18,88 & 20,56 \\
desvio padrão & 0,25 & 1,62 & 2,25 & 355 & 0,92 & 6,47 & 1,53 & 1,25 \\
\hline & 1,20 & 17,3 & 21,0 & 9148 & 17,0 & 14,0 & 38,5 & 36,8 \\
coletado & 0,70 & 12,3 & 16,0 & 9135 & 17,3 & 9,5 & 41,0 & 47,5 \\
no plantio & 0,70 & 11,5 & 16,5 & 9475 & 16,8 & 12,5 & 41,3 & 41,8 \\
da alface & 0,70 & 10,0 & 13,5 & 8068 & 16,5 & 10,8 & 37,3 & 37,0 \\
& 0,95 & 12,0 & 13,8 & 7870 & 14,5 & 8,8 & 32,0 & 28,5 \\
& 0,95 & 10,0 & 14,8 & 8395 & 15,5 & 5,3 & 32,5 & 32,8 \\
média & 0,87 & 12,2 & 15,9 & 8682 & 16,3 & 10,1 & 37,1 & 37,4 \\
desvio padrão & 0,20 & 2,67 & 2,76 & 659 & 1,05 & 3,07 & 4,04 & 6,67 \\
\hline \multirow{3}{*}{ coletado } & 0,95 & 18,5 & 13,5 & 7665 & 14,0 & 12,8 & 31,8 & 26,5 \\
na & 0,95 & 13,0 & 12,8 & 6938 & 13,3 & 7,50 & 32,8 & 27,3 \\
colheita & 0,95 & 15,8 & 15,0 & 7728 & 14,8 & 11,0 & 41,5 & 44,8 \\
da alface & 1,20 & 16,3 & 18,3 & 6800 & 13,8 & 11,3 & 73,5 & 31,5 \\
& 1,20 & 22,5 & 14,3 & 6790 & 17,8 & 7,00 & 35,0 & 29,5 \\
média & 0,95 & 16,5 & 13,5 & 7275 & 15,8 & 10,3 & 40,0 & 29,3 \\
desvio padråo & 1,03 & 17,1 & 14,5 & 7199 & 14,9 & 9,96 & 42,4 & 31,5 \\
\hline
\end{tabular}


Tabela A19. Teores de elementos químicos nas amostras do podzólico vermelho-amarelo após a extração com $\mathrm{MgCl}_{2}$ em fracionamento seqüencial $\left(\mathrm{MgCl}_{2}\right.$, acetato de sódio, hidroxilamina, nitrico/ $\mathrm{H}_{2} \mathrm{O}_{2}$, nítrico-perclórico)

\begin{tabular}{|c|c|c|c|c|c|c|c|c|}
\hline \multirow{2}{*}{$\begin{array}{c}\mathrm{MgCl} 2 \\
\text { amostra }\end{array}$} & $\mathrm{Cd}$ & $\mathrm{Cr}$ & $\mathrm{Cu}$ & $\mathrm{Fe}$ & $\mathrm{Mn}$ & $\mathrm{Ni}$ & $\mathrm{Pb}$ & $\mathrm{Zn}$ \\
\hline & \multicolumn{8}{|c|}{$\mathrm{mg} \mathrm{kg-1}$} \\
\hline \multirow{5}{*}{$\begin{array}{c}\text { não } \\
\text { cultivado }\end{array}$} & 0,00 & 0,25 & 0,00 & 0,00 & 197 & 0,00 & 0,00 & 6,25 \\
\hline & 0,00 & 0,00 & 0,00 & 0,00 & 200 & 0,00 & 0,00 & 5,25 \\
\hline & 0,00 & 0,50 & 0,00 & 0,00 & 193 & 0,00 & 0,00 & 1,00 \\
\hline & 0,00 & 0,00 & 0,00 & 0,00 & 192 & 0,00 & 0,00 & 1,00 \\
\hline & 0,00 & 0,00 & 0,00 & 0,00 & 188 & 0,00 & 0,00 & 0,50 \\
\hline média & 0,00 & 0,15 & 0,00 & 0,00 & 194 & 0,00 & 0,00 & 2,80 \\
\hline desvio padrão & 0,00 & 0,22 & 0,00 & 0,00 & 4,53 & 0,00 & 0,00 & 2,72 \\
\hline \multirow{6}{*}{$\begin{array}{l}\text { coletado } \\
\text { no plantio } \\
\text { da alface }\end{array}$} & 0,00 & 0,25 & 0,50 & 0,00 & 158 & 0,00 & 0,00 & 0,00 \\
\hline & 0,00 & 0,25 & 0,25 & 0,00 & 167 & 0,00 & 0,00 & 0,00 \\
\hline & 0,00 & 0,25 & 0,25 & 0,00 & 166 & 0,00 & 0,00 & 0,00 \\
\hline & 0,00 & 0,00 & 0,25 & 0,00 & 166 & 0,00 & 0,00 & 0,00 \\
\hline & 0,00 & 0,25 & 0,25 & 0,00 & 165 & 0,00 & 0,00 & 0,00 \\
\hline & 0,25 & 0,25 & 0,25 & 0,00 & 144 & 0,00 & 0,00 & 0,00 \\
\hline média & 0,04 & 0,21 & 0,29 & 0,00 & 161 & 0,00 & 0,00 & 0,00 \\
\hline \multirow{2}{*}{ desvio padrăo } & 0,10 & 0,10 & 0,10 & 0,00 & 8,80 & 0,00 & 0,00 & 0,00 \\
\hline & 0,00 & 0,00 & 0,50 & 0,00 & 160 & 0,00 & 0,00 & 0,00 \\
\hline coletado & 0,25 & 0,00 & 0,50 & 0,00 & 157 & 0,00 & 0,00 & 0,00 \\
\hline & 0,50 & 0,50 & 0,75 & 0,00 & 157 & 0,00 & 0,00 & 0,00 \\
\hline colheita & 0,00 & 0,50 & 0,50 & 0,00 & 158 & 0,00 & 0,00 & 0,00 \\
\hline \multirow[t]{2}{*}{ da alface } & 0,00 & 0,00 & 0,50 & 0,00 & 159 & 0,00 & 0,00 & 0,00 \\
\hline & 0,00 & 0,00 & 0,50 & 0,00 & 162 & 0,00 & 0,00 & 0,00 \\
\hline média & 0,13 & 0,17 & 0,54 & 0,00 & 159 & 0,00 & 0,00 & 0,00 \\
\hline desvio padrăo & 0,21 & 0,26 & 0,10 & 0,00 & 1,97 & 0,00 & 0,00 & 0,00 \\
\hline \multirow{6}{*}{$\begin{array}{l}\text { coletado } \\
\text { na } \\
\text { colheita } \\
\text { da } \\
\text { beterraba }\end{array}$} & 0,00 & 0,00 & 0,25 & 0,00 & 191 & 0,00 & 0,00 & 0,00 \\
\hline & 0,00 & 0,00 & 0,25 & 0,00 & 170 & 0,00 & 0,00 & 0,00 \\
\hline & 0,00 & 0,00 & 0,25 & 0,00 & 150 & 0,00 & 0,00 & 0,00 \\
\hline & 0,00 & 0,50 & 0,50 & 0,00 & 166 & 0,00 & 0,00 & 0,00 \\
\hline & 0,00 & 0,50 & 0,50 & 0,00 & 168 & 0,00 & 0,00 & 0,00 \\
\hline & 0,00 & 0,00 & 0,25 & 0,00 & 166 & 0,00 & 0,00 & 0,00 \\
\hline média & 0,00 & 0,17 & 0,33 & 0,00 & 168 & 0,00 & 0,00 & 0,00 \\
\hline desvio padrăo & 0,00 & 0,26 & 0,13 & 0,00 & 13,24 & 0,00 & 0,00 & 0,00 \\
\hline
\end{tabular}


Tabela A20. Teores de elementos químicos nas amostras do solo podzólico vermelho-amarelo após a extração com acetato de sódio em fracionamento seqüencial $\left(\mathrm{MgCl}_{2}\right.$, acetato de sódio, hidroxilamina, nítrico/ $\mathrm{H}_{2} \mathrm{O}_{2}$, nítricoperclórico)

\begin{tabular}{|c|c|c|c|c|c|c|c|c|}
\hline \multirow{2}{*}{$\begin{array}{l}\text { acetato Na } \\
\text { anostras. }\end{array}$} & $\mathrm{Cd}$ & $\mathrm{Cr}$ & $\mathrm{Cu}$ & $\mathrm{Fe}$ & $\mathrm{Mn}$ & $\mathrm{Ni}$ & $\mathrm{Pb}$ & $\mathrm{Zn}$ \\
\hline & \multicolumn{8}{|c|}{$\mathrm{mg} \mathrm{kg}^{-1}$} \\
\hline \multirow{5}{*}{$\begin{array}{c}\text { não } \\
\text { cultivado }\end{array}$} & 0,00 & 0,00 & 0,00 & 0,00 & 5,50 & 0,00 & 0,00 & 0,50 \\
\hline & 0,00 & 0,00 & 0,00 & 0,00 & 5,25 & 0,00 & 0,00 & 0,00 \\
\hline & 0,00 & 0,00 & 0,00 & 0,00 & 5,25 & 0,00 & 0,00 & 0,00 \\
\hline & 0,00 & 0,00 & 0,00 & 0,00 & 5,50 & 0,00 & 0,00 & 0,00 \\
\hline & 0,00 & 0,00 & 0,00 & 0,00 & 4,00 & 0,00 & 0,00 & 0,00 \\
\hline \multirow{3}{*}{$\begin{array}{c}\text { média } \\
\text { desvio padrão }\end{array}$} & 0,00 & 0,00 & 0,00 & 0,00 & 5,10 & 0,00 & 0,00 & 0,10 \\
\hline & 0,00 & 0,00 & 0,00 & 0,00 & 0,56 & 0,00 & 0,00 & 0,20 \\
\hline & 0,00 & 0,00 & 3,00 & 0,00 & 73,3 & 0,00 & 0,00 & 33,3 \\
\hline \multirow{5}{*}{$\begin{array}{l}\text { coletado no } \\
\text { plantio da } \\
\text { alface }\end{array}$} & 0,00 & 0,00 & 2,75 & 0,00 & 75,3 & 0,00 & 0,00 & 28,0 \\
\hline & 0,00 & 0,00 & 2,75 & 0,00 & 75,5 & 0,00 & 0,00 & 28,0 \\
\hline & 0,00 & 0,00 & 2,50 & 0,00 & 77,0 & 0,00 & 0,00 & 25,3 \\
\hline & 0,00 & 0,00 & 3,25 & 0,00 & 75,8 & 0,00 & 0,00 & 26,0 \\
\hline & 0,00 & 0,00 & 2,25 & 0,00 & 69,5 & 0,00 & 0,00 & 25,3 \\
\hline \multirow{3}{*}{$\begin{array}{c}\text { média } \\
\text { desvio padrão }\end{array}$} & 0,00 & 0,00 & 2,75 & 0,00 & 74,4 & 0,00 & 0,00 & 27,6 \\
\hline & 0,00 & 0,00 & 0,35 & 0,00 & 2,68 & 0,00 & 0,00 & 3,03 \\
\hline & 0,00 & 0,00 & 2,50 & 0,00 & 78,0 & 0,00 & 0,00 & 28,8 \\
\hline \multirow{5}{*}{$\begin{array}{l}\text { coletado na } \\
\text { colheita da } \\
\text { alface }\end{array}$} & 0,00 & 0,00 & 2,75 & 0,00 & 83,0 & 0,00 & 0,00 & 30,5 \\
\hline & 0,00 & 0,00 & 3,00 & 0,00 & 88,0 & 0,00 & 0,00 & 28,8 \\
\hline & 0,00 & 0,00 & 2,75 & 0,00 & 85,0 & 0,00 & 0,00 & 28,3 \\
\hline & 0,00 & 0,00 & 2,75 & 0,00 & 80,8 & 0,00 & 0,00 & 27,3 \\
\hline & 0,00 & 0,00 & 2,75 & 0,00 & 79,3 & 0,00 & 0,00 & 27,3 \\
\hline \multirow{3}{*}{$\begin{array}{c}\text { média } \\
\text { desvio padrão }\end{array}$} & 0,00 & 0,00 & 2,75 & 0,00 & 82,3 & 0,00 & 0,00 & 28,5 \\
\hline & 0,00 & 0,00 & 0,16 & 0,00 & 3,75 & 0,00 & 0,00 & 1,21 \\
\hline & 0,00 & 0,00 & 2,75 & 0,00 & 72,5 & 0,00 & 0,00 & 26,5 \\
\hline \multirow{5}{*}{$\begin{array}{c}\text { coletado na } \\
\text { colheita da } \\
\text { beterraba }\end{array}$} & 0,00 & 0,00 & 2,25 & 0,00 & 75,5 & 0,00 & 0,00 & 22,3 \\
\hline & 0,00 & 0,00 & 2,25 & 0,00 & 78,5 & 0,00 & 0,00 & 21,3 \\
\hline & 0,00 & 0,00 & 2,25 & 0,00 & 77,3 & 0,00 & 0,00 & 21,5 \\
\hline & 0,00 & 0,00 & 2,25 & 0,00 & 80,0 & 0,00 & 0,00 & 21,8 \\
\hline & 0,00 & 0,00 & 2,50 & 0,00 & 71,0 & 0,00 & 0,00 & 21,5 \\
\hline \multirow{2}{*}{$\begin{array}{l}\text { média } \\
\text { esvio padrão }\end{array}$} & 0,00 & 0,00 & 2,38 & 0,00 & 75,8 & 0,00 & 0,00 & 22,5 \\
\hline & 0,00 & 0,00 & 0,21 & 0,00 & 3,49 & 0,00 & 0,00 & 2,01 \\
\hline
\end{tabular}


Tabela A21. Teores de elementos químicos nas amostras do podzólico vermelhoamarelo após a extração com hidroxilamina em fracionamento seqüencial $\left(\mathrm{MgCl}_{2}\right.$, acetato de sódio, hidroxilamina, nítrico/ $\mathrm{H}_{2} \mathrm{O}_{2}$, nítrico-perclórico)

\begin{tabular}{|c|c|c|c|c|c|c|c|c|}
\hline \multirow{2}{*}{ hidroxilamina } & $\mathrm{Cd}$ & $\mathrm{Cr}$ & $\mathrm{Cu}$ & $\mathrm{Fe}$ & $\mathrm{Mn}$ & $\mathrm{Ni}$ & $\mathrm{Pb}$ & $\mathrm{Zn}$ \\
\hline & \multicolumn{8}{|c|}{$\mathrm{mg} \mathrm{kg}^{-1}$} \\
\hline \multirow{5}{*}{$\begin{array}{c}\text { não } \\
\text { cultivado }\end{array}$} & 0,25 & 4,75 & 1,00 & 2613 & 8,75 & 2,50 & 2,00 & 6,25 \\
\hline & 0,25 & 5,00 & 0,75 & 2775 & 9,00 & 2,50 & 2,75 & 6,00 \\
\hline & 0,25 & 5,00 & 0,50 & 2595 & 9,50 & 2,75 & 0,00 & 4,75 \\
\hline & 0,00 & 5,25 & 0,75 & 2788 & 7,50 & 3,00 & 4,00 & 5,25 \\
\hline & 0,00 & 5,50 & 0,75 & 2675 & 8,00 & 2,50 & 2,75 & 5,25 \\
\hline média & 0,15 & 5,10 & 0,75 & 2689 & 8,55 & 2,65 & 2,30 & 5,50 \\
\hline \multirow{2}{*}{ desvio padrão } & 0,14 & 0,29 & 0,18 & 89,42 & 0,80 & 0,22 & 1,47 & 0,61 \\
\hline & 0,25 & 10,3 & 8,00 & 2975 & 66,3 & 2,75 & 13,5 & 114 \\
\hline \multirow{5}{*}{$\begin{array}{l}\text { coletado no } \\
\text { plantio da } \\
\text { alface }\end{array}$} & 0,25 & 8,8 & 7,25 & 2663 & 73,5 & 2,75 & 11,5 & 106 \\
\hline & 0,00 & 9,3 & 7,50 & 2850 & 64,0 & 2,50 & 16,8 & 101 \\
\hline & 0,00 & 8,3 & 8,50 & 2908 & 65,5 & 2,50 & 15,5 & 98,5 \\
\hline & 0,25 & 8,5 & 8,50 & 2870 & 68,8 & 2,50 & 10,5 & 98,5 \\
\hline & 0,25 & 8,3 & 7,25 & 2705 & 67,5 & 3,00 & 9,75 & 103 \\
\hline \multirow{3}{*}{$\begin{array}{c}\text { média } \\
\text { desvio padrăo }\end{array}$} & 0,17 & 8,88 & 7,83 & 2828 & 67,6 & 2,67 & 12,9 & 103 \\
\hline & 0,13 & 0,77 & 0,58 & 121 & 3,33 & 0,20 & 2,81 & 5,71 \\
\hline & 0,25 & 10,8 & 8,75 & 2788 & 76,0 & 2,50 & 15,8 & 103,25 \\
\hline \multirow{5}{*}{$\begin{array}{l}\text { coletado na } \\
\text { colheita da } \\
\text { alface }\end{array}$} & 0,25 & 7,00 & 6,75 & 2668 & 66,8 & 2,50 & 12,8 & 111,00 \\
\hline & 0,25 & 8,00 & 8,00 & 2528 & 68,0 & 2,50 & 13,3 & 98,25 \\
\hline & 0,25 & 7,25 & 8,00 & 2580 & 64,3 & 2,25 & 12,8 & 96,00 \\
\hline & 0,25 & 9,50 & 8,50 & 2990 & 70,8 & 2,00 & 10,3 & 109,25 \\
\hline & 0,25 & 9,25 & 8,00 & 2855 & 68,8 & 2,50 & 14,5 & 100,00 \\
\hline \multirow{3}{*}{$\begin{array}{c}\text { média } \\
\text { desvio padrăo }\end{array}$} & 0,25 & 8,38 & 8,25 & 2759 & 68,8 & 2,13 & 14,5 & 105,71 \\
\hline & 0,00 & 1,46 & 0,69 & 175 & 4,02 & 0,21 & 1,86 & 6,06 \\
\hline & 0,25 & 8,8 & 9,25 & 2805 & 103 & 2,50 & 11,0 & 102 \\
\hline \multirow{5}{*}{$\begin{array}{c}\text { coletado na } \\
\text { colheita da } \\
\text { beterraba }\end{array}$} & 0,25 & 7,0 & 7,25 & 2620 & 66,8 & 2,75 & 13,3 & 91,0 \\
\hline & 0,25 & 6,8 & 6,25 & 2290 & 61,0 & 2,75 & 10,8 & 81,5 \\
\hline & 0,25 & 8,5 & 8,75 & 2865 & 66,8 & 2,75 & 13,5 & 91,0 \\
\hline & 0,25 & 9,0 & 8,25 & 2865 & 68,8 & 2,75 & 14,3 & 98,3 \\
\hline & 0,25 & 9,5 & 10,00 & 2910 & 60,5 & 2,75 & 11,0 & 91,5 \\
\hline média & 0,25 & 8,25 & 8,29 & 2726 & 71,0 & 2,71 & 12,3 & 92,5 \\
\hline desvio padrăo & 0,00 & 1,12 & 1,36 & 237 & 15,8 & 0,10 & 1,54 & 7,00 \\
\hline
\end{tabular}


Tabela A22. Teores de elementos químicos nas amostras do solo podzólico vermelho-amarelo após a extração com ácido nítrico/ $\mathrm{H} 2 \mathrm{O} 2 \mathrm{em}$ fracionamento seqüencial $\left(\mathrm{MgCl}_{2}\right.$, acetato de sódio, hidroxilamina, nítrico/ $\mathrm{H}_{2} \mathrm{O}_{2}$, nítricoperclórico)

\begin{tabular}{|c|c|c|c|c|c|c|c|c|}
\hline nitricof $\mathrm{H}_{2} \mathrm{O}_{2}$ & $\mathrm{Cd}$ & $\mathrm{Cr}$ & $\mathrm{Cu}$ & $\mathrm{Fe}$ & $\mathrm{Mn}$ & $\mathrm{Ni}$ & $\mathrm{Pb}$ & $\mathrm{Zn}$ \\
\hline amostra & \multicolumn{8}{|c|}{$\mathrm{mg} \mathrm{kg}^{-1}$} \\
\hline nitrico/ $\psi_{2} \mathrm{O}_{2}$ & $\mathrm{Cd}$ & $\mathrm{Cr}$ & $\mathrm{Cu}$ & $\mathrm{Fe}$ & $\mathrm{Mn}$ & $\mathrm{Ni}$ & $\mathrm{Pb}$ & $\mathrm{Zn}$ \\
\hline \multirow{5}{*}{$\begin{array}{c}\text { não } \\
\text { cultivado }\end{array}$} & 0,00 & 6,5 & 2,25 & 43,0 & 1,25 & 0,0 & 0,0 & 0,00 \\
\hline & 0,00 & 5,8 & 1,50 & 25,0 & 0,50 & 0,0 & 0,3 & 0,00 \\
\hline & 0,00 & 6,3 & 1,50 & 28,0 & 0,75 & 0,0 & 0,3 & 0,00 \\
\hline & 0,00 & 5,5 & 1,75 & 27,5 & 0,75 & 0,0 & 0,3 & 0,00 \\
\hline & 0,00 & 6,0 & 1,75 & 25,0 & 1,00 & 0,0 & 0,0 & 0,00 \\
\hline média & 0,00 & 6,00 & 1,75 & 29,7 & 0,85 & 0,00 & 0,15 & 0,00 \\
\hline desvio padrão & 0,00 & 0,40 & 0,31 & 7,56 & 0,29 & 0,00 & 0,14 & 0,00 \\
\hline \multirow{6}{*}{$\begin{array}{l}\text { coletado no } \\
\text { plantio da } \\
\text { alface }\end{array}$} & 0,00 & 7,5 & 29,0 & 12,0 & 2,25 & 7,00 & 2,00 & 10,3 \\
\hline & 0,00 & 7,3 & 33,3 & 29,3 & 2,75 & 1,25 & 1,75 & 12,3 \\
\hline & 0,25 & 8,3 & 32,8 & 14,5 & 2,00 & 0,25 & 2,75 & 12,3 \\
\hline & 0,00 & 7,3 & 32,3 & 24,8 & 2,75 & 0,75 & 3,50 & 15,0 \\
\hline & 0,00 & 7,0 & 31,8 & 22,0 & 2,25 & 4,75 & 3,75 & 11,5 \\
\hline & 0,00 & 7,8 & 33,5 & 27,8 & 2,75 & 2,75 & 5,25 & 14,0 \\
\hline média & 0,04 & 7,50 & 32,1 & 21,7 & 2,46 & 2,79 & 3,17 & 12,5 \\
\hline desvio padrăo & 0,10 & 0,45 & 1,64 & 7,06 & 0,33 & 2,63 & 1,29 & 1,71 \\
\hline \multirow{6}{*}{$\begin{array}{l}\text { coletado na } \\
\text { colheita da } \\
\text { alface }\end{array}$} & 0,00 & 10,8 & 35,3 & 35,8 & 2,50 & 2,25 & 1,75 & 12,5 \\
\hline & 0,00 & 7,25 & 38,8 & 49,8 & 2,75 & 2,25 & 0,00 & 15,8 \\
\hline & 0,00 & 8,00 & 38,0 & 36,5 & 3,00 & 1,50 & 2,75 & 16,3 \\
\hline & 0,00 & 6,50 & 31,0 & 36,8 & 2,50 & 13,3 & 0,00 & 11,0 \\
\hline & 0,00 & 7,25 & 32,3 & 32,0 & 2,50 & 3,25 & 0,00 & 11,0 \\
\hline & 0,00 & 7,25 & 30,8 & 18,3 & 2,50 & 6,50 & 0,00 & 11,3 \\
\hline média & 0,00 & 7,83 & 34,3 & 34,8 & 2,63 & 4,83 & 0,75 & 13,0 \\
\hline desvio padrão & 0,00 & 1,51 & 3,52 & 10,13 & 0,21 & 4,49 & 1,20 & 2,43 \\
\hline \multirow{6}{*}{$\begin{array}{l}\text { coletado na } \\
\text { colheita da } \\
\text { beterraba }\end{array}$} & 0,00 & 7,00 & 31,0 & 8,75 & 8,00 & 2,50 & 3,00 & 13,3 \\
\hline & 0,00 & 7,00 & 30,0 & 13,0 & 2,75 & 0,00 & 2,25 & 11,0 \\
\hline & 0,00 & 7,00 & 25,8 & 11,5 & 3,50 & 0,50 & 3,50 & 13,5 \\
\hline & 0,25 & 6,25 & 26,0 & 7,50 & 3,00 & 0,75 & 3,75 & 10,8 \\
\hline & 0,00 & 6,50 & 26,3 & 9,25 & 2,50 & 4,25 & 4,00 & 11,8 \\
\hline & 0,00 & 6,25 & 25,3 & 0,00 & 2,25 & 0,00 & 3,00 & 9,00 \\
\hline média & 0,04 & 6,67 & 27,4 & 8,33 & 3,67 & 1,33 & 3,25 & 11,5 \\
\hline desvio padrăo & 0,10 & 0,38 & 2,46 & 4,54 & 2,17 & 1,70 & 0,63 & 1,68 \\
\hline
\end{tabular}


Tabela A23. Teor de elementos químicos nas amostras do podzólico vermelhoamarelo após a extração nítrica-perclórica em fracionamento seqüencial $\left(\mathrm{MgCl}_{2}\right.$, acetato de sódio, hidroxilamina, nítrico/ $\mathrm{H}_{2} \mathrm{O}_{2}$, nítrico-perclórico)

\begin{tabular}{|c|c|c|c|c|c|c|c|c|}
\hline \multirow{2}{*}{$\begin{array}{l}\text { nitr-percl: } \\
\text { amostra }\end{array}$} & $\mathrm{Cd}$ & $\mathrm{Cr}$ & $\mathrm{Cu}$ & $\mathrm{Fe}$ & $\mathrm{Mn}$ & $\mathrm{Ni}$ & $\mathrm{Pb}$ & $\mathrm{Zn}$ \\
\hline & \multicolumn{8}{|c|}{$\mathrm{mg} \mathrm{kg}^{-1}$} \\
\hline \multirow{5}{*}{$\begin{array}{c}\text { não } \\
\text { cultivado }\end{array}$} & 2,00 & 31,5 & 10,8 & 48545 & 16,8 & 8,75 & 0,00 & 15,8 \\
\hline & 1,75 & 28,8 & 6,50 & 46275 & 16,0 & 7,50 & 0,00 & 13,8 \\
\hline & 1,75 & 31,5 & 10,50 & 48645 & 16,3 & 8,75 & 0,00 & 14,5 \\
\hline & 1,75 & 31,5 & 10,50 & 46005 & 16,5 & 9,50 & 0,00 & 16,3 \\
\hline & 1,75 & 31,3 & 11,00 & 50615 & 17,3 & 9,00 & 0,00 & 15,3 \\
\hline \multirow{3}{*}{$\begin{array}{c}\text { média } \\
\text { desvio padrăo }\end{array}$} & 1,80 & 30,9 & 9,85 & 48017 & 16,6 & 8,70 & 0,00 & 15,1 \\
\hline & 0,11 & 1,21 & 1,88 & 1904 & 0,48 & 0,74 & 0,00 & 0,99 \\
\hline & 1,50 & 28,5 & 18,5 & 43015 & 18,5 & 9,00 & 18,3 & 26,5 \\
\hline \multirow{5}{*}{$\begin{array}{l}\text { coletado no } \\
\text { plantio da } \\
\text { alface }\end{array}$} & 1,50 & 25,0 & 17,8 & 40505 & 18,0 & 8,00 & 20,0 & 26,0 \\
\hline & 1,25 & 28,3 & 19,8 & 44735 & 19,0 & 9,25 & 27,5 & 31,3 \\
\hline & 1,25 & 30,0 & 19,3 & 45325 & 18,0 & 12,5 & 23,3 & 28,8 \\
\hline & 1,75 & 27,5 & 20,5 & 46295 & 18,0 & 7,25 & 20,8 & 27,8 \\
\hline & 1,25 & 28,8 & 19,8 & 46215 & 18,3 & 7,50 & 21,0 & 31,0 \\
\hline \multirow{3}{*}{$\begin{array}{c}\text { média } \\
\text { desvio padrăo }\end{array}$} & 1,42 & 28,0 & 19,3 & 44348 & 18,3 & 8,92 & 21,8 & 28,5 \\
\hline & 0,20 & 1,68 & 0,99 & 2233 & 0,40 & 1,93 & 3,23 & 2,22 \\
\hline & 1,25 & 35,5 & 18,8 & 38965 & 18,8 & 13,3 & 21,0 & 51,5 \\
\hline \multirow{5}{*}{$\begin{array}{l}\text { coletado na } \\
\text { colheita da } \\
\text { alface }\end{array}$} & 1,25 & 36,0 & 20,8 & 44005 & 19,5 & 13,3 & 25,3 & 36,5 \\
\hline & 0,75 & 32,0 & 19,8 & 44475 & 19,8 & 16,3 & 22,3 & 33,3 \\
\hline & 1,50 & 27,0 & 17,3 & 39755 & 17,8 & 11,3 & 18,5 & 23,8 \\
\hline & 1,50 & 36,8 & 20,3 & 44805 & 23,0 & 15,8 & 20,5 & 33,3 \\
\hline & 1,50 & 36,5 & 20,5 & 45345 & 21,5 & 15,5 & 20,3 & 32,0 \\
\hline \multirow{3}{*}{$\begin{array}{c}\text { média } \\
\text { desvio padräo }\end{array}$} & 1,29 & 34,0 & 19,5 & 42892 & 20,0 & 14,2 & 21,3 & 35,0 \\
\hline & 0,31 & 4,04 & 1,39 & 2805 & 1,98 & 2,05 & 2,49 & 10,06 \\
\hline & 1,50 & 25,0 & 15,3 & 39375 & 21,3 & 8,75 & 18,8 & 32,3 \\
\hline \multirow{5}{*}{$\begin{array}{l}\text { coletado na } \\
\text { colheita da } \\
\text { beterraba }\end{array}$} & 1,25 & 28,8 & 15,5 & 38255 & 17,5 & 11,0 & 17,0 & 24,3 \\
\hline & 1,50 & 31,5 & 18,8 & 43905 & 16,8 & 15,0 & 18,5 & 26,8 \\
\hline & 1,50 & 33,8 & 18,8 & 43365 & 20,3 & 19,8 & 19,0 & 29,5 \\
\hline & 1,50 & 31,5 & 21,3 & 42065 & 19,3 & 7,50 & 17,5 & 27,5 \\
\hline & 1,50 & 31,0 & 17,8 & 41155 & 19,3 & 8,25 & 18,5 & 29,0 \\
\hline \multirow{2}{*}{$\begin{array}{c}\text { média } \\
\text { desvio padrão }\end{array}$} & 1,46 & 30,3 & 17,9 & 41353 & 19,0 & 11,7 & 18,2 & 28,2 \\
\hline & 0,10 & 3,02 & 2,26 & 2219 & 1,68 & 4,78 & 0,78 & 2,72 \\
\hline
\end{tabular}




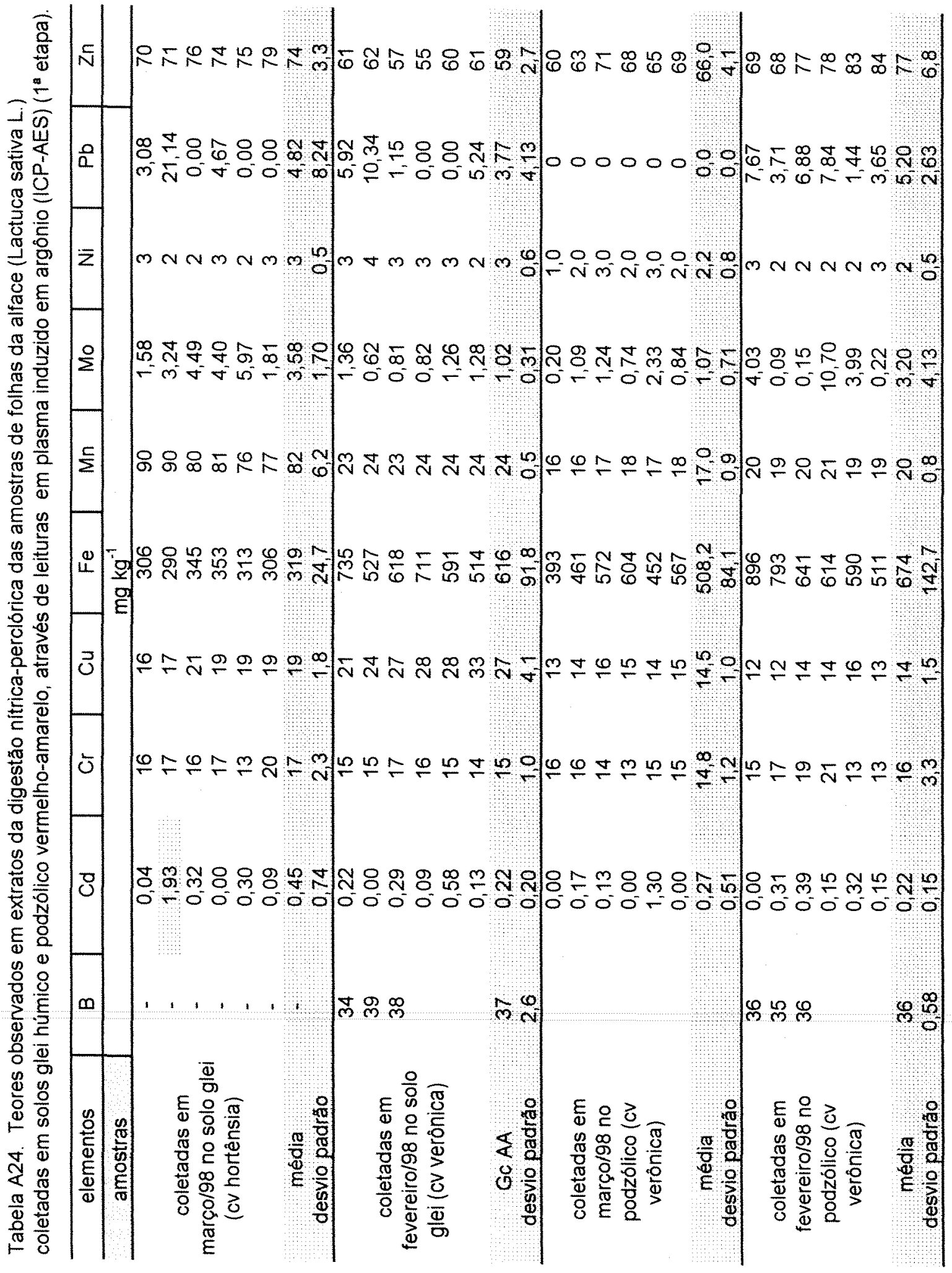




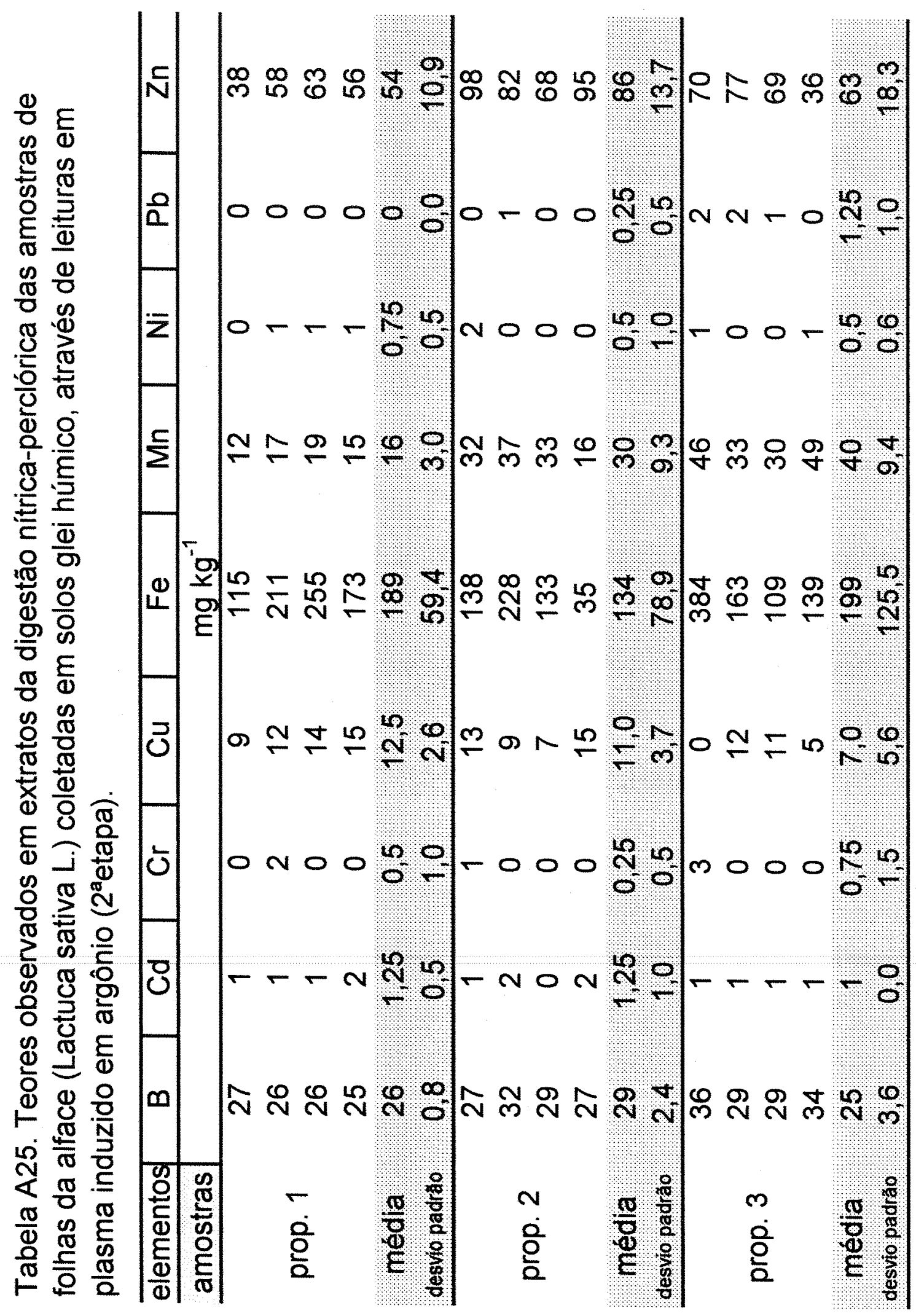




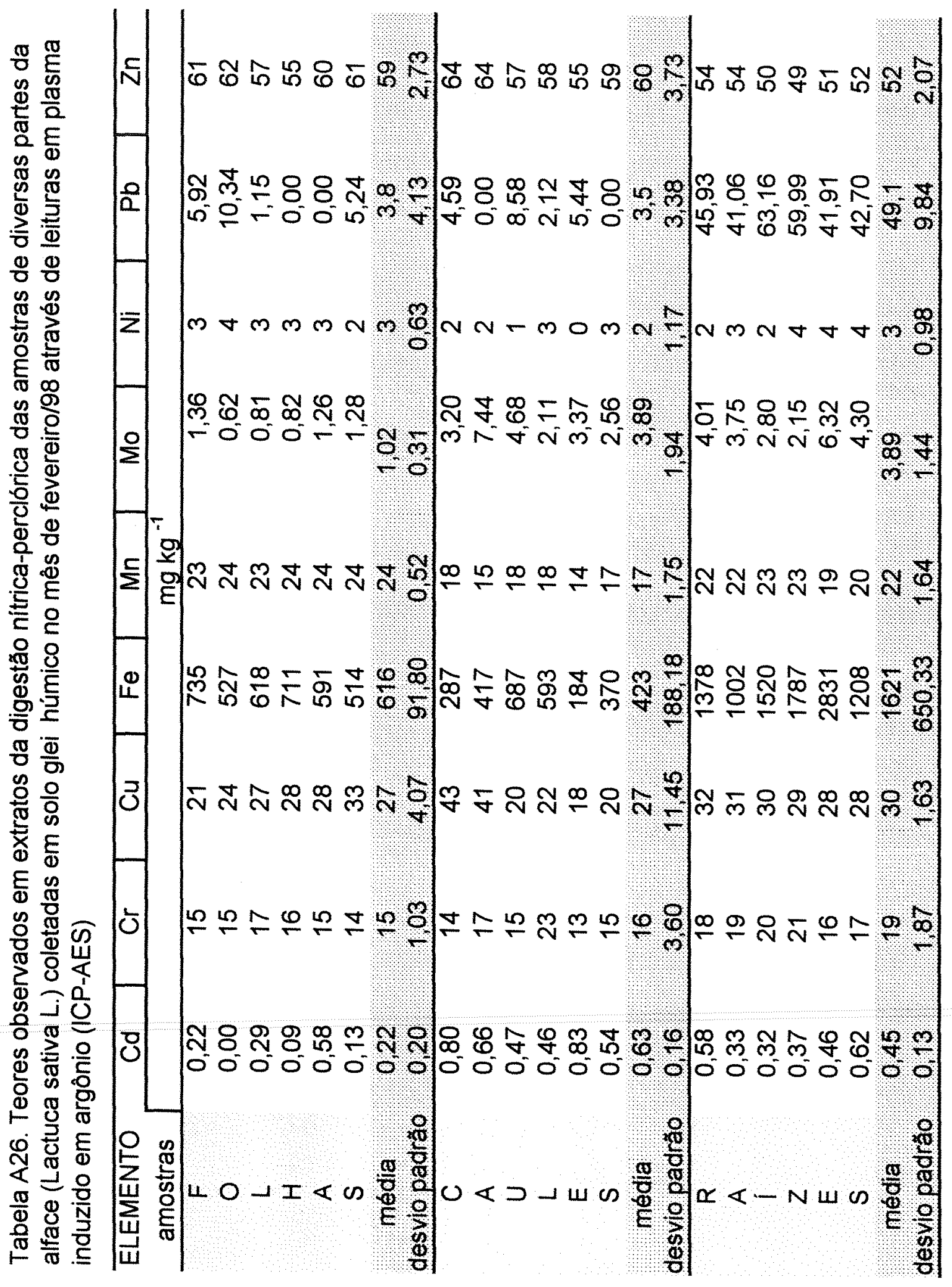




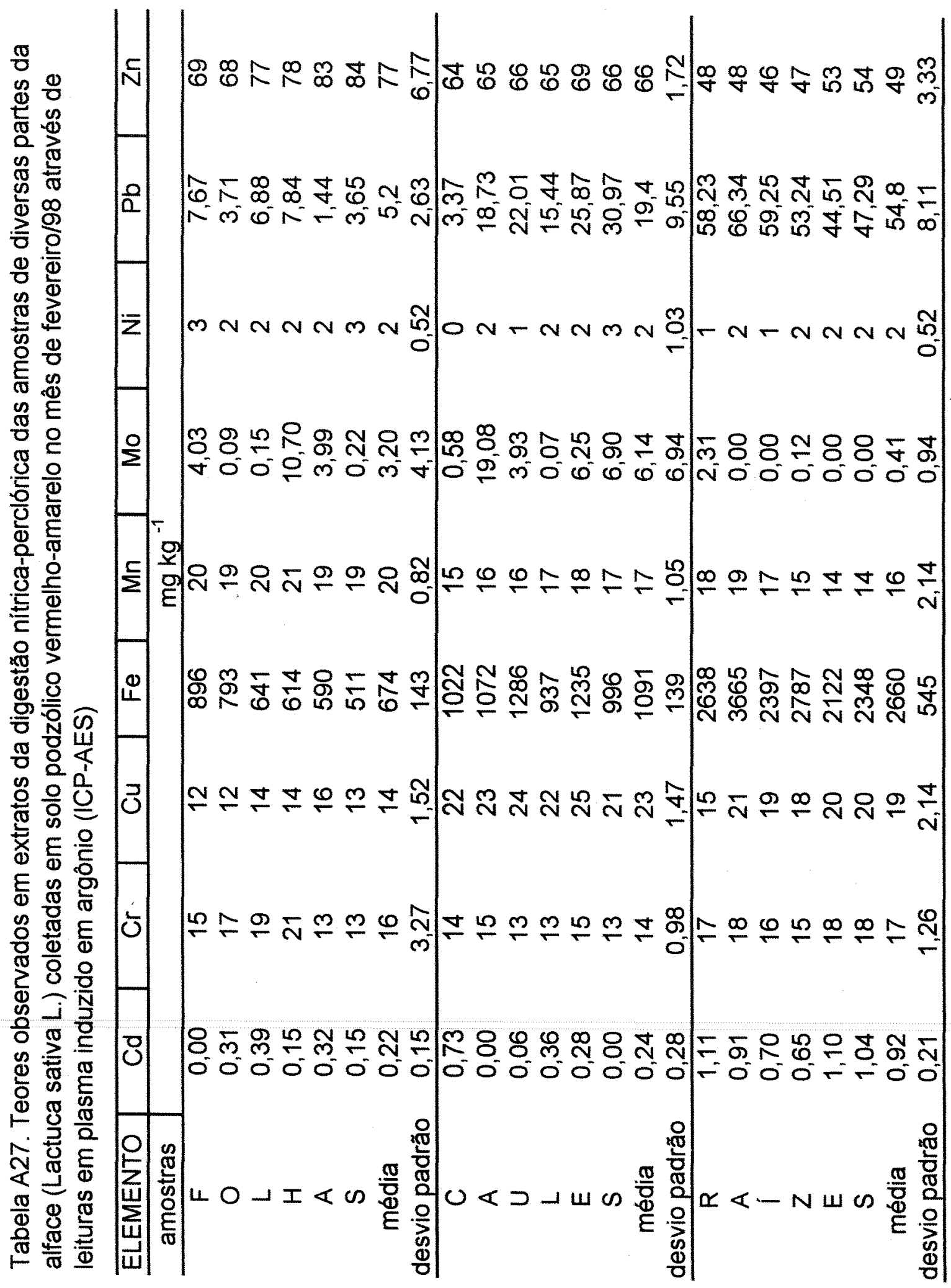




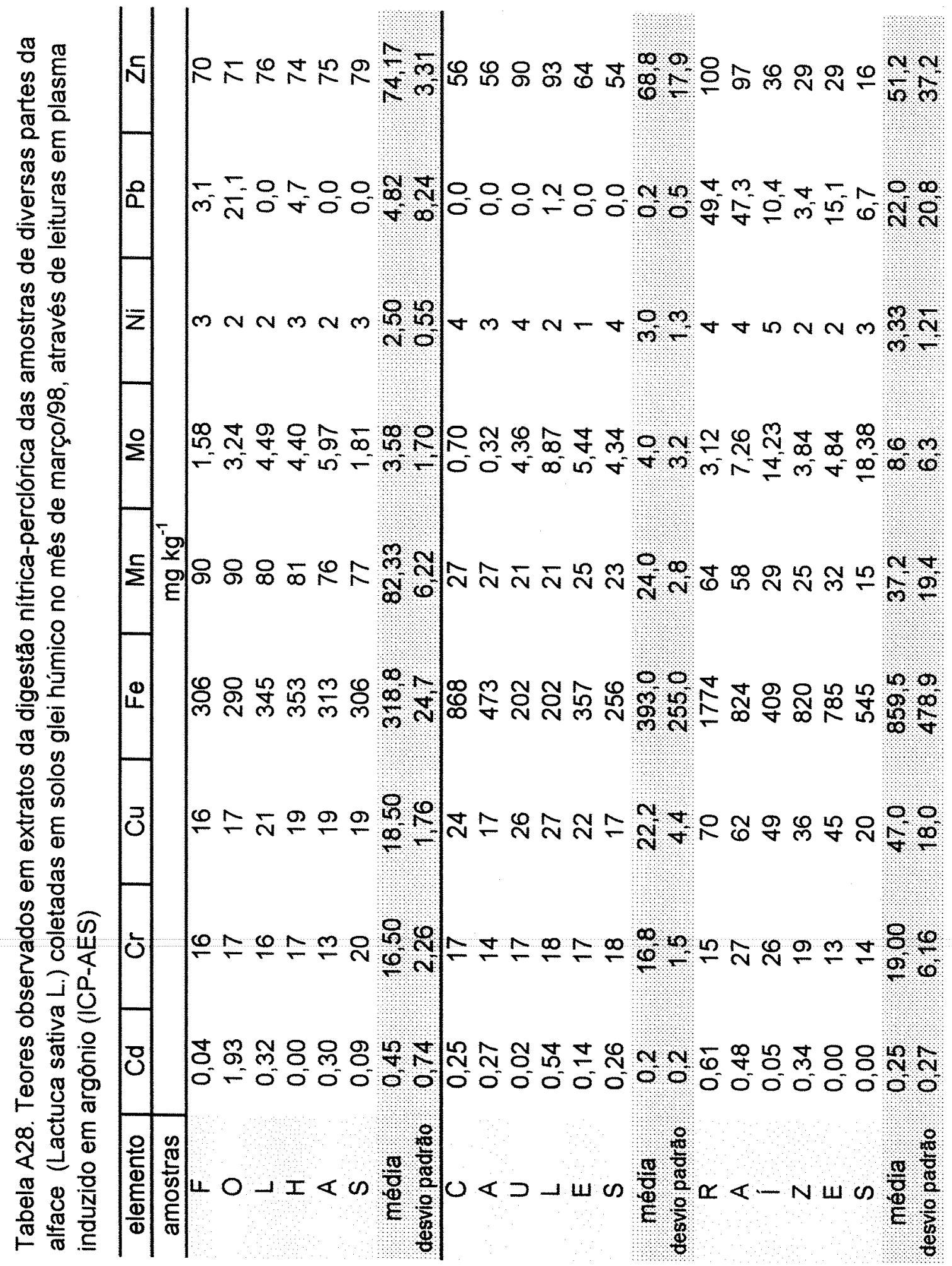




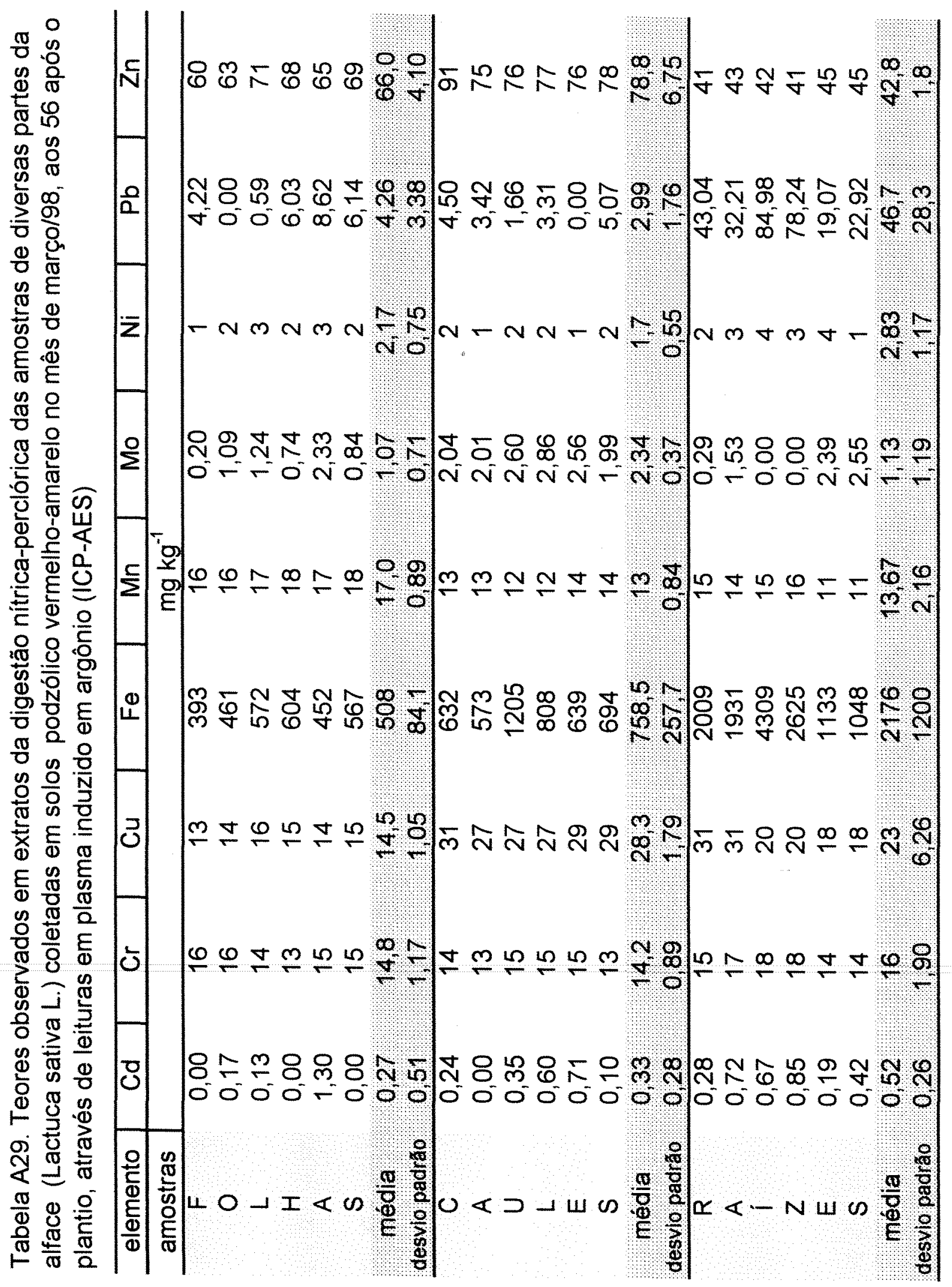




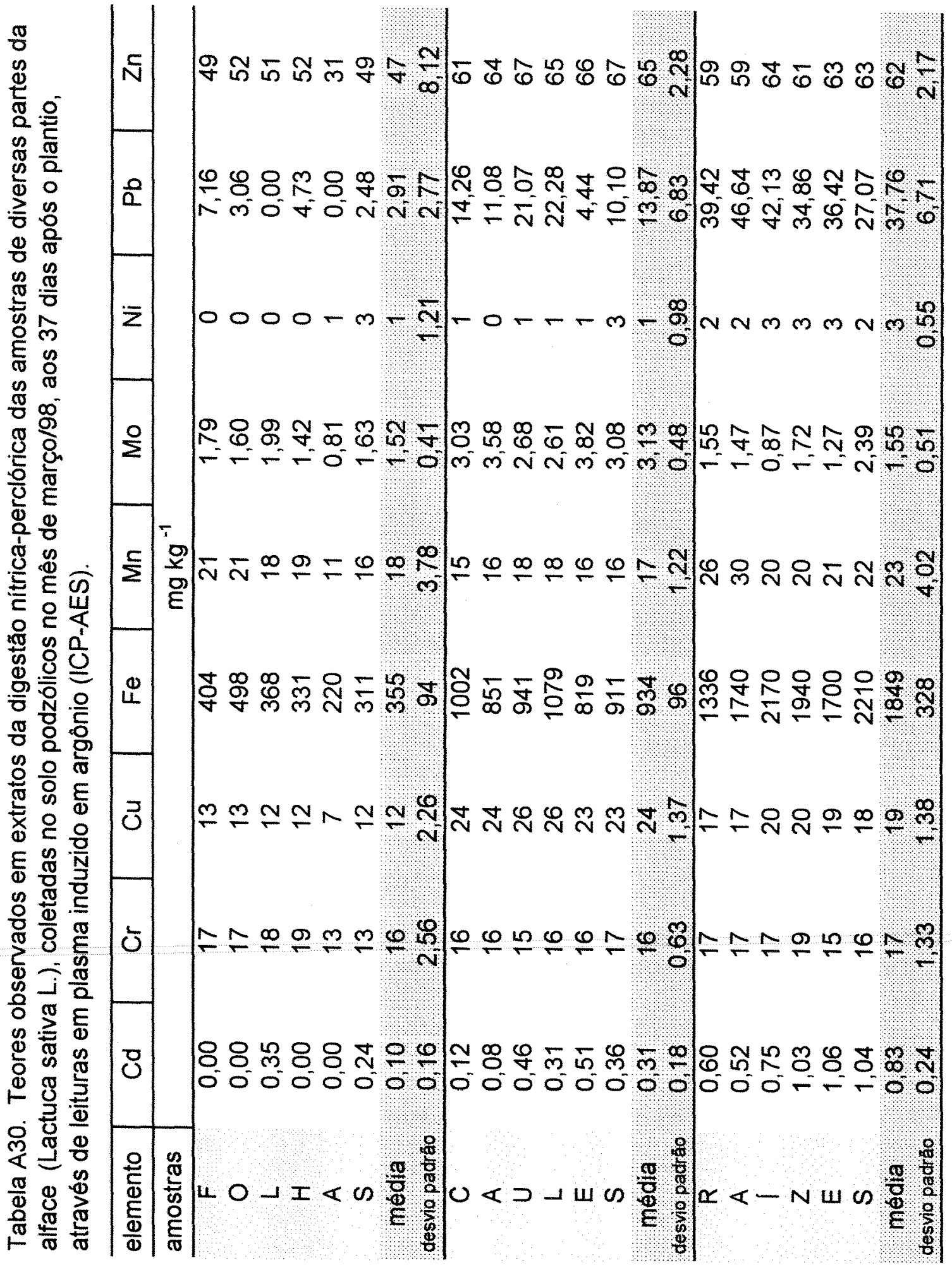




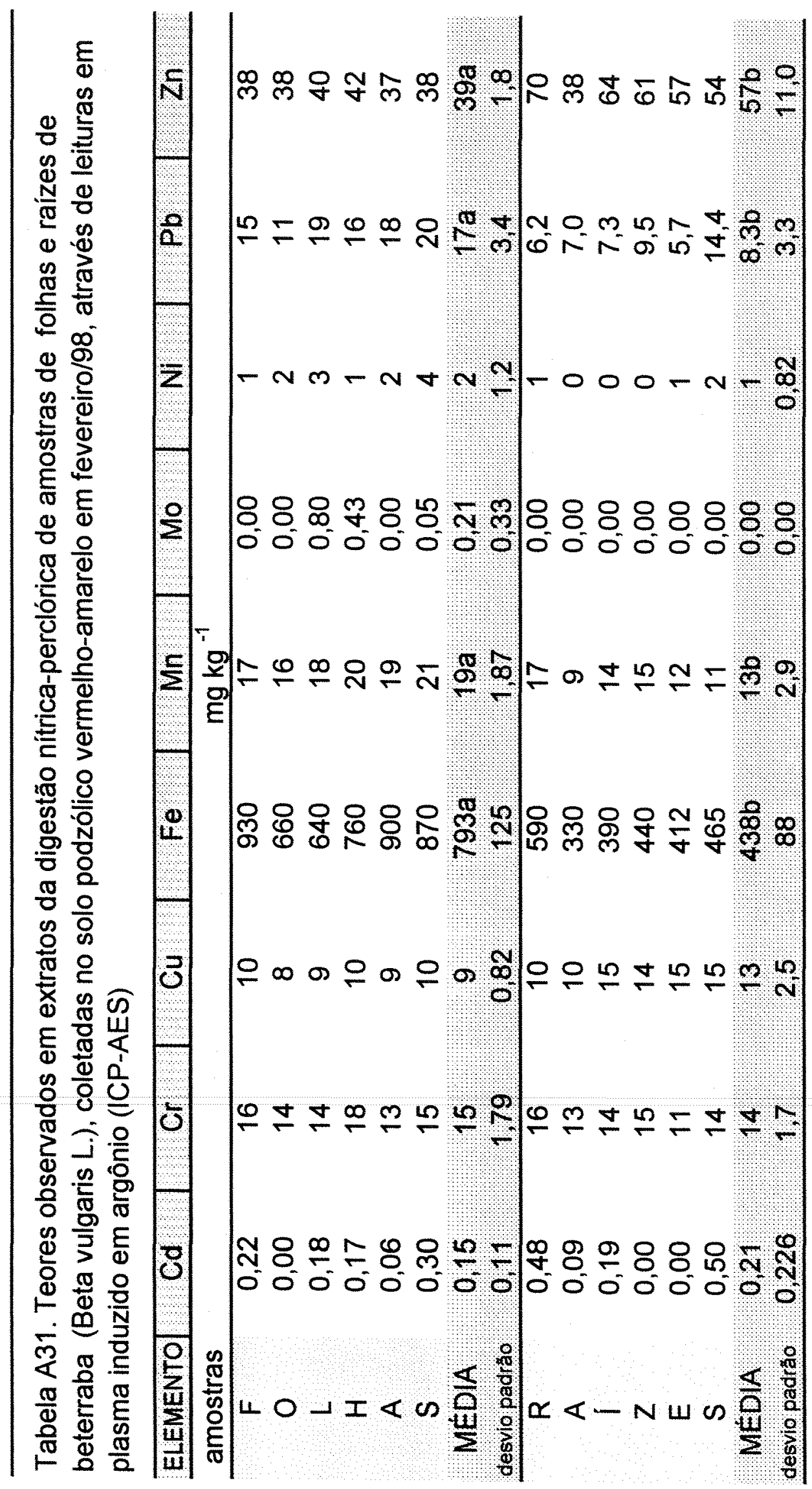




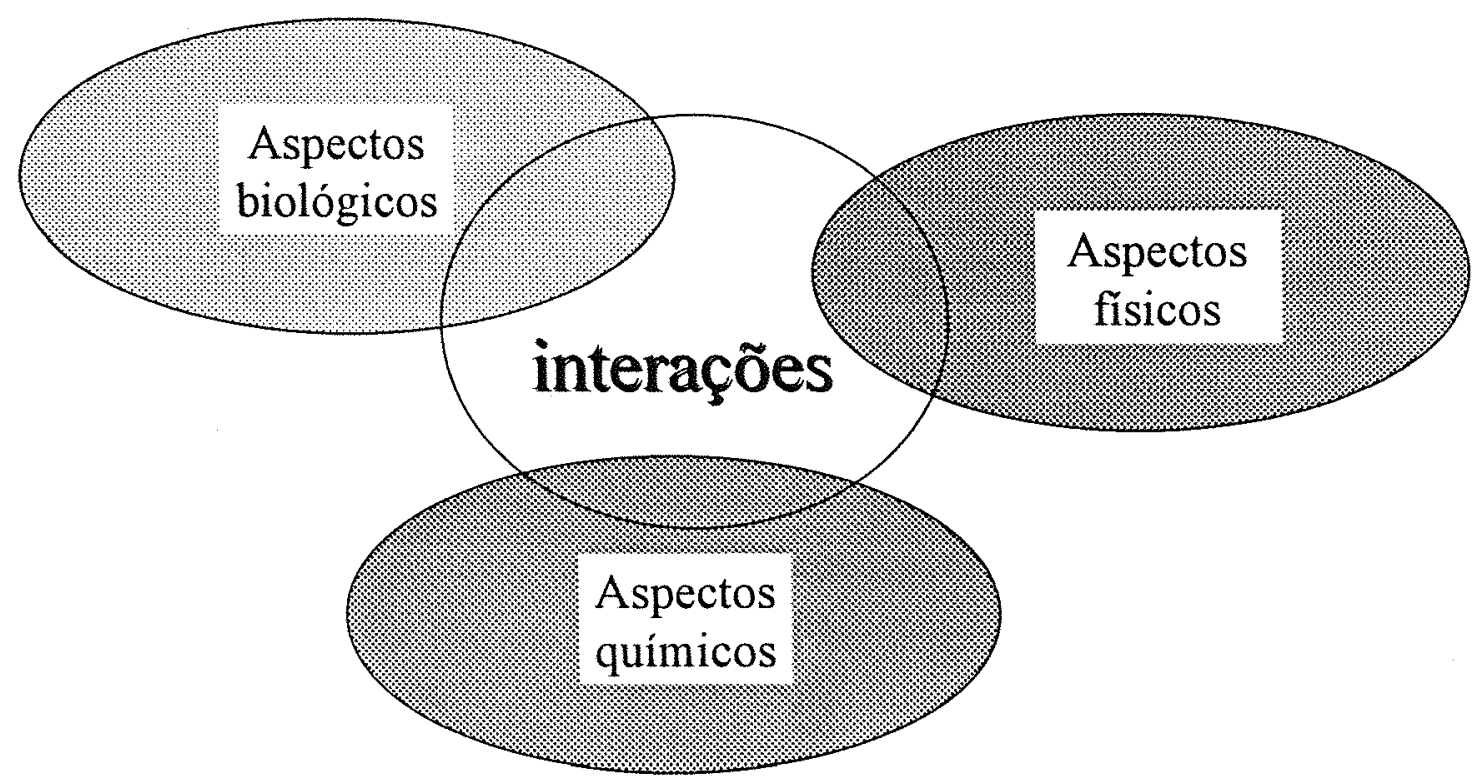

Figura A1. Aspectos intrínsecos da ciclagem de nutrientes e sustentabilidade agrícola

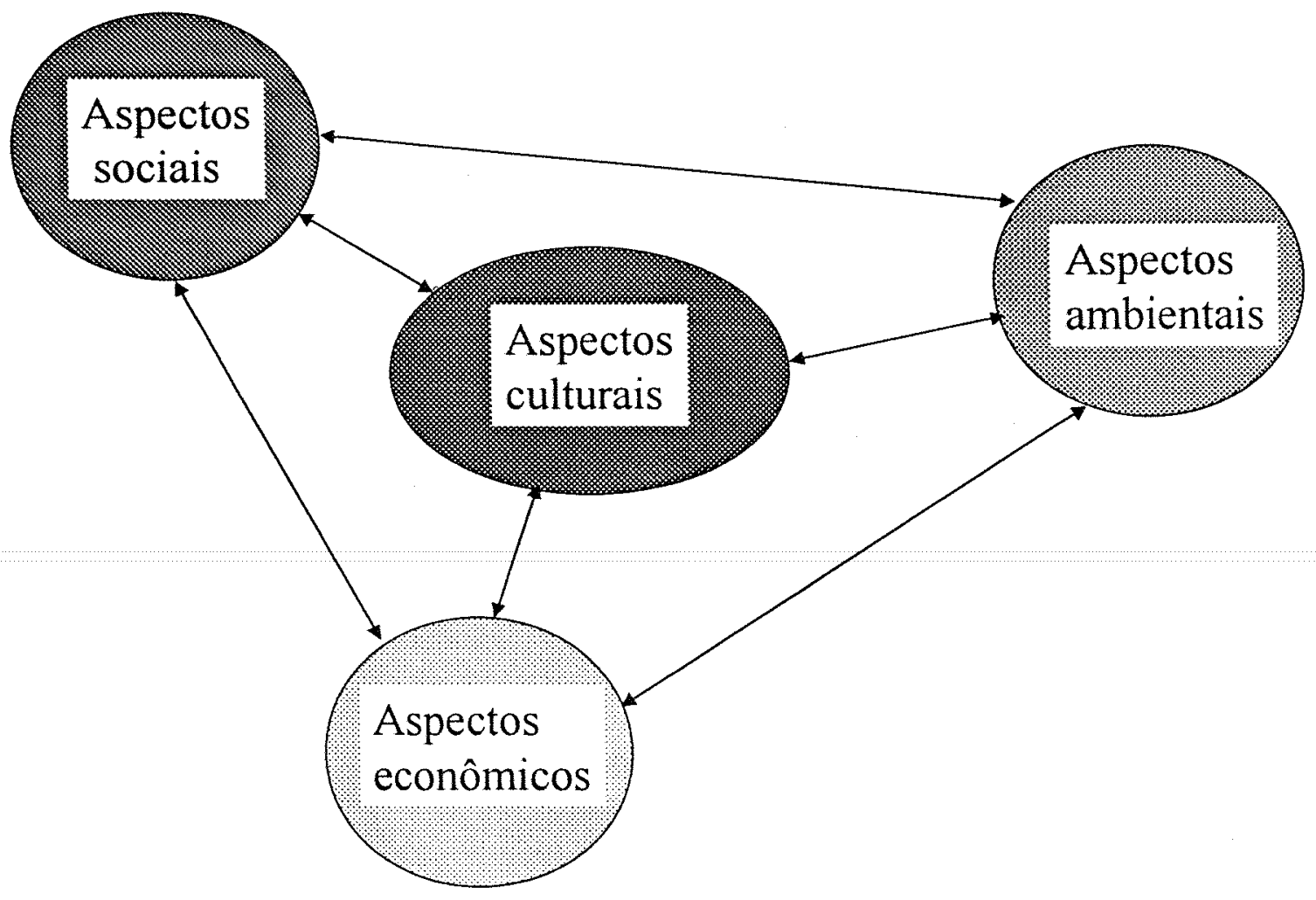

Figura A2. Aspectos conjunturais da ciclagem de nutrientes e sustentabilidade agricola. 